UNIVERSIDADE DE SÃO PAULO

FACULDADE DE ECONOMIA, ADMINISTRAÇÃO E CONTABILIDADE DEPARTAMENTO DE ADMINISTRAÇÃO PROGRAMA DE PÓS-GRADUAÇÃO EM ADMINISTRAÇÃO

\title{
FORMAS HÍBRIDAS E FOOD SERVICE: UMA ANÁLISE DA ALOCAÇÃO DE AUTORIDADE EM FRANQUIAS DE ALIMENTAÇÃO NO BRASIL
}


Prof. Dr. Marco Antonio Zago

Reitor da Universidade de São Paulo

Prof. Dr. Adalberto Américo Fishmann

Diretor da Faculdade de Economia, Administração e Contabilidade

Prof. Dr. Roberto Sbragia

Chefe do Departamento de Administração

Prof. Dr. Moacir de Miranda Oliveira Junior

Coordenador do Programa de Pós-Graduação em Administração 


\title{
FORMAS HÍBRIDAS E FOOD SERVICE: \\ UMA ANÁLISE DA ALOCAÇÃO DE AUTORIDADE EM FRANQUIAS DE ALIMENTAÇÃO NO BRASIL
}

\author{
Tese apresentada ao Departamento de \\ Administração da Faculdade de Economia, \\ Administração e Contabilidade da Universidade de \\ São Paulo como requisito para a obtenção do título \\ de Doutor em Ciências.
}

Orientadora: Prof ${ }^{\mathrm{a}}$. Dr ${ }^{\mathrm{a}}$. Maria Sylvia Macchione Saes

VERSÃO CORRIGIDA

(Versão original disponível na Faculdade de Economia, Administrção e Contabilidade)

SÃO PAULO 


\section{FICHA CATALOGRÁFICA}

Elaborada pela Seção de Processamento Técnico do SBD/FEA/USP

\section{Dolnikoff, Fabio}

Formas híbridas e food service : uma análise da alocação de autoridade em franquias de alimentação no Brasil / Fabio Dolnikoff. -- São Paulo, 2015.

$238 \mathrm{p}$.

Tese (Doutorado) - Universidade de São Paulo, 2015.

Orientadora: Maria Sylvia Macchione Saes

1. Franquia 2. Delegação de autoridade 3. Administração de hotéis e restaurantes I. Universidade de São Paulo. Faculdade de Economia, Administração e Contabilidade. II. Título.

$$
\text { CDD }-658.8708
$$


À minha avó, Clara Sterman. 


\section{AGRADECIMENTOS}

À minha esposa Daniela e à minha filha Mariana, pelo amor e incentivo que me ajudaram tanto a ultrapassar cada etapa deste desafio.

Aos meus pais, pelo amor e torcida inabaláveis.

À Professora Sylvia Saes, minha orientadora, por todo apoio, disposição e ajuda inestimáveis durante o curso de pós-graduação.

À colaboração da amiga Maria d’Lúcia Granja Coutinho.

Aos amigos e pós-graduandos do CORS, pela contribuição ao desenvolvimento de meu projeto de pesquisa e tese.

Aos companheiros do curso de pós-graduação em administração, por uma convivência tão positiva e incentivadora.

Ao sócio-diretor da Francap, Sr. André Friedheim, e aos executivos entrevistados da Hamburgeria, Pizza Delivery e Cafeteria, pela disponibilidade em participar desta pesquisa.

À Eloisa Alessio e à sua equipe da secretaria de pós-graduação, pelo apoio frente às questões burocráticas do curso.

Ao CNPQ, pela bolsa de estudos. 


\section{RESUMO}

Este trabalho tem como objetivo propor um modelo econômico para os determinantes da alocação de autoridade em cadeias franqueadas no Brasil no setor de alimentação fora do lar food service. Baseando-se no aporte teórico da economia neoinstitucionalista, especialmente na linha teórica desenvolvida por Claude Ménard (2004; 2010) para o estudo das formas híbridas, foi aplicado um estudo de múltiplos casos com foco em uma hamburgeria, uma pizza delivery e uma cafeteria, em que se procurou discutir a hipótese de que um aumento na complexidade no ponto de venda (lojas que demandam grande esforço operacional) levaria à descentralização do arranjo franqueado. Observou-se que a complexidade no ponto de venda realmente influencia a alocação de direitos de propriedade dos arranjos, mas no sentido contrário ao esperado, ou seja, no sentido da centralização. Tal centralização foi caracterizada por uma integração de determinadas tarefas básicas e pelo aumento do controle efetivo exercido pelas franqueadoras sobre as tarefas que continuaram sendo compartilhadas com as lojas franqueadas.

Palavras-chave: franquia; delegação de autoridade; administração de hotéis e restaurantes. 


\begin{abstract}
This work intends to propose an economic model reflecting the determinants of authority allocation on food service franchise chains in Brazil. Drawing on the New Institutional Economics framework and, in particular, on the hybrid forms approach by Claude Ménard (2004; 2010), a multiple case study has been conducted on a hamburger fast food restaurant chain, a pizza delivery chain and a special coffee shop chain, discussing the hypothesis that: the more outlet complexity increases (stores that demand high operational effort), the more decentralized the chain should be. Results show that outlet complexity is indeed a determinant of the allocation of property rights, although in the opposite direction, i.e. towards centralization. Such centralization was characterized as a mix of: vertical integration over key tasks and of an increase in the effective control over the remaining tasks that kept being shared with franchisees.
\end{abstract}

Key words: franchising; delegation of authority; food service. 


\section{SUMÁRIO}

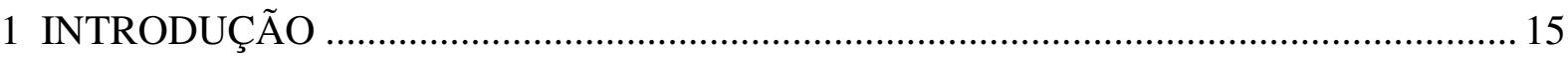

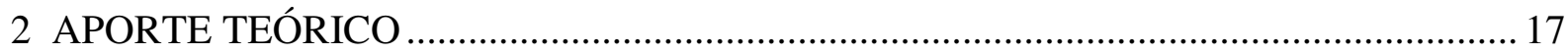

2.1 A firma e o mercado como alternativas de governança ................................................ 17

2.2 Williamson e a Economia dos Custos de Transação ...................................................... 18

2.2.1 Pressupostos comportamentais.................................................................... 18

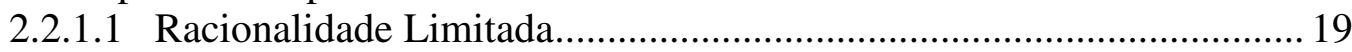

2.2.1.2 Oportunismo .................................................................................. 20

2.2.2 A transação como unidade de análise ............................................................... 20

2.2.3 Alinhamento e ECT................................................................................. 20

2.2.3.1 Especificidade dos ativos, quase-renda e o problema de hold-up ........ 22

2.2.3.2 Mecanismos e estruturas de governança: esclarecendo a nomenclatura 23

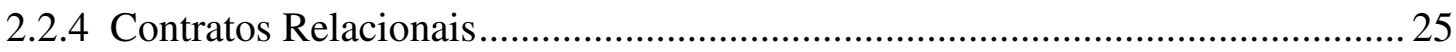

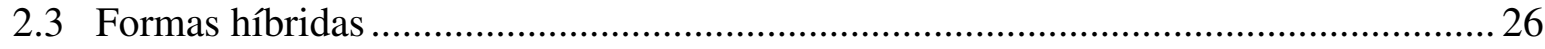

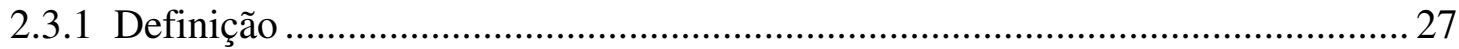

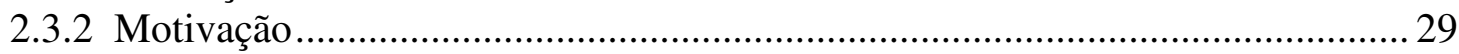

2.3.2.1 Coordenação de atividades conjuntas .................................................... 29

2.3.2.2 Alocação de pay-offs .............................................................................. 30

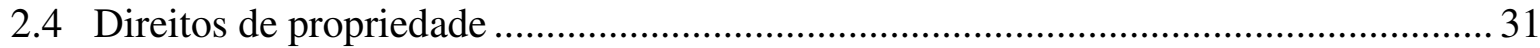

2.5 North e a influência do ambiente institucional.............................................................. 32

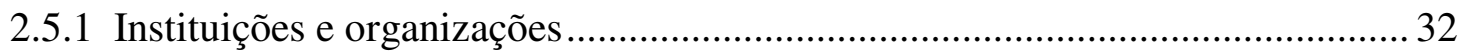

2.5.2 Instituições, direitos de propriedade e custos de transação ..................................... 33

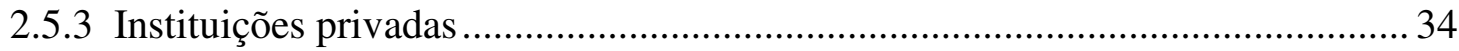

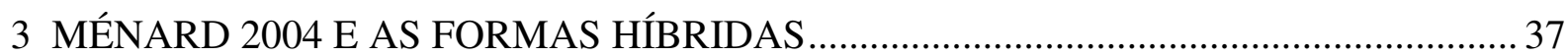

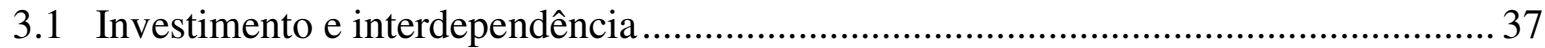

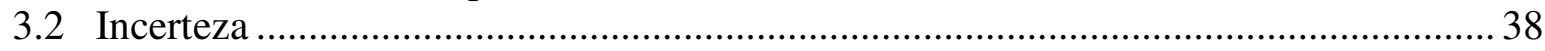

3.3 O Modelo de 2004 e seus mecanismos de governança ................................................... 39

3.3.1 Equalização do risco contratual nas relações híbridas .......................................... 40

3.3.2 Divisão da quase-renda ................................................................................. 41

3.3.3 Salvaguardas (enforcement issues) ................................................................. 42

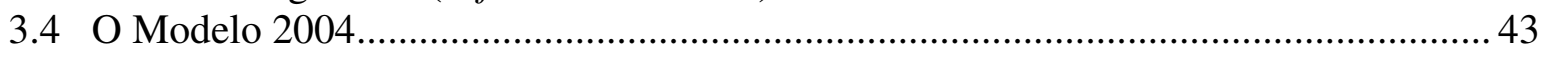

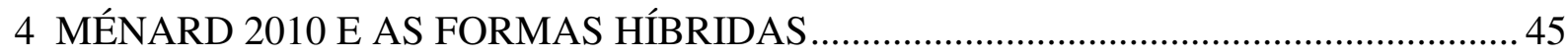

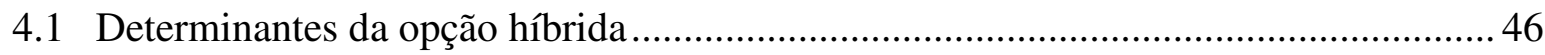

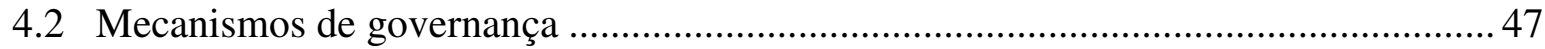

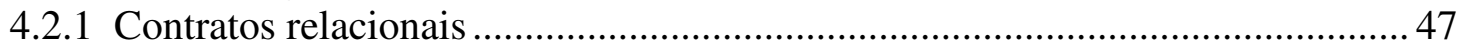

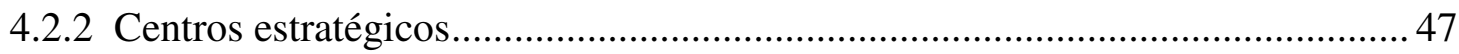

4.2.3 Entidades exógenas (third parties) ................................................................... 48

4.2.4 Redes de informação …………………………………………………….... 49

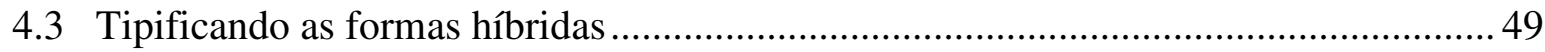

4.4 Relacionando as variáveis do Modelo................................................................. 51

4.5 Ilustrando o Modelo de Ménard (2010) ……………..................................................52

5 O SETOR DE ALIMENTAÇÃO FORA DO LAR ………………………….................. 57

5.1 A classificação das atividades do setor ……………………………………………......59

5.1.1 A classificação das atividades do setor segunda a Euromonitor ..........................59 
5.1.2 A Classificação segundo o Anuário de Alimentação Fora do Lar ..................... 62

5.1.3 A Classificação das atividades do setor segundo o USDA ................................. 63

5.1.4 A Classificação das atividades do setor segundo a CHD Expert .......................63

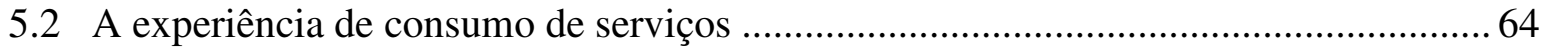

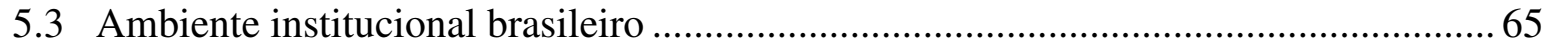

6 ECONOMIA DAS ORGANIZAÇÕES E FRANQUIAS (Franchising Economics) .......... 67

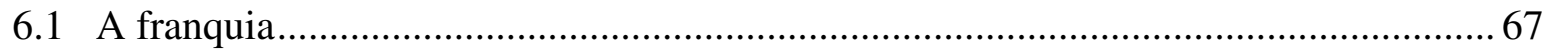

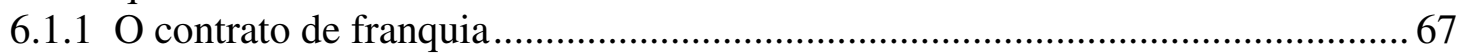

6.2 Franchising e Teoria da Agência ......................................................................6 69

6.3 Franchising e a Economia dos Custos de Transação ................................................ 69

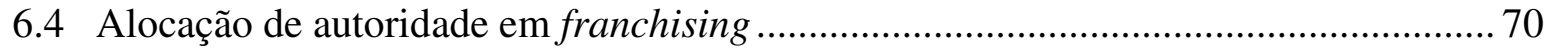

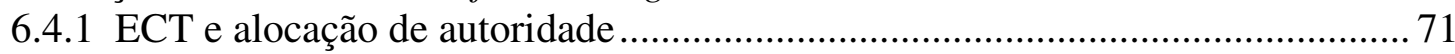

6.5 Controle em redes franqueadas ......................................................................... 71

6.6 Diferentes arranjos baseados em franchising ................................................. 72

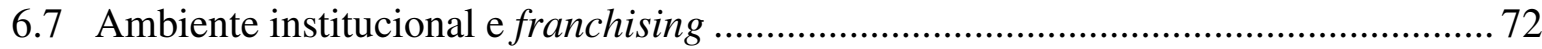

7 ANÁLISE EMPÍRICA: A ALOCAÇÃO DE AUTORIDADE EM CADEIAS

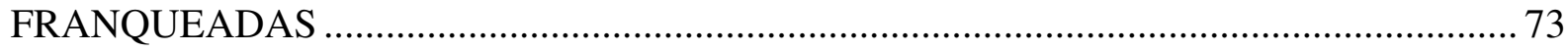

7.1 Retomando o problema de pesquisa e objetivos .................................................... 73

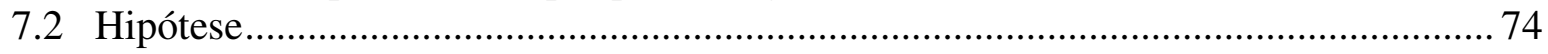

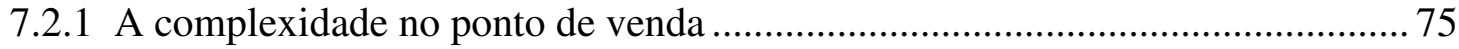

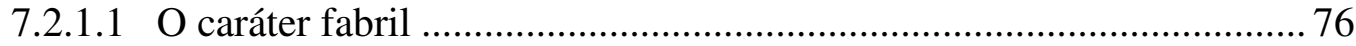

7.2.1.2 O caráter de serviços ................................................................ 77

7.2.2 A relação entre complexidade e descentralização ........................................ 79

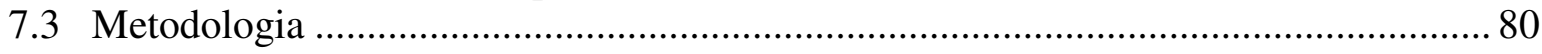

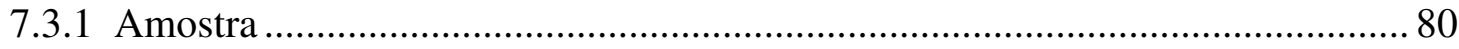

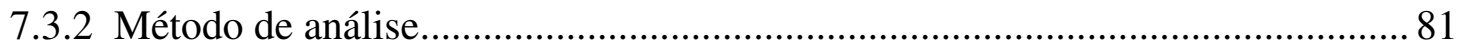

7.3.2.1 Alocação de tarefas como proxy para alocação de direitos de

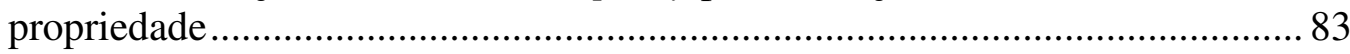

7.3.2.2 O conjunto de tarefas necessário à análise ...................................... 85

7.3.2.3 O efeito de complementariedade entre os contratos............................. 86

7.3.2.4 Estratégia competitiva como variável de controle ............................. 87

7.3.2.5 O ambiente institucional como variável de controle .......................... 88

7.3.3 Método de coleta ............................................................................... 88

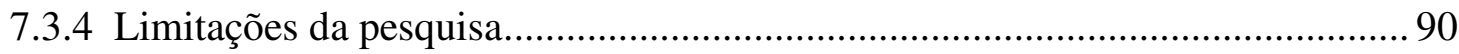

7.3.4.1 Sobre a utilização do constructo de CPV ........................................... 90

7.3.4.2 Mecanismos do Modelo de Ménard (2010) ...................................... 91

7.3.4.3 Confidencialidade................................................................ 91

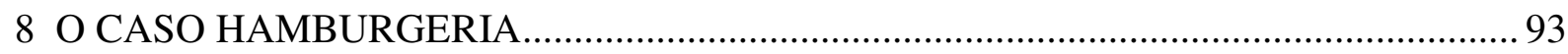

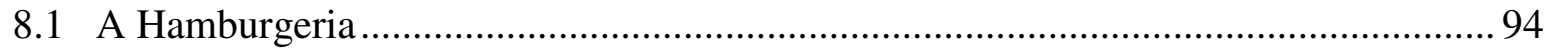

8.1.1 A unidade de negócios da Hamburgeria: o restaurante .................................. 94

8.1.2 A estrutura física de atendimento do restaurante ...................................... 95

8.1.3 A linha de produtos .................................................................................. 95

8.1.3.1 A organização da oferta da linha de produtos no restaurante .............. 96

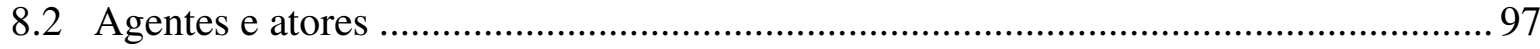

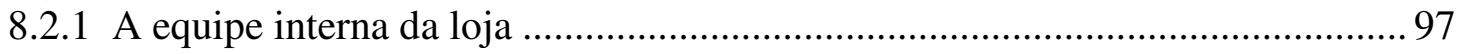

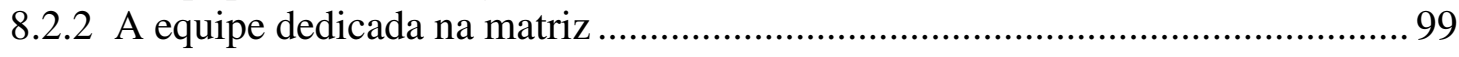

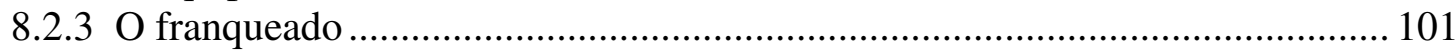




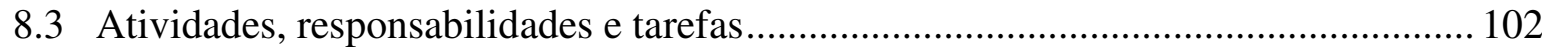

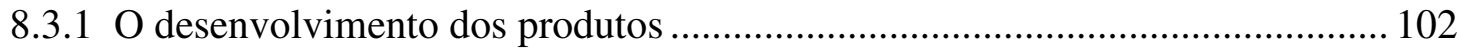

8.3.2 O desenvolvimento e veiculação de promoções e propaganda ........................... 103

8.3.3 A expansão da rede e a escolha do ponto comercial .......................................... 104

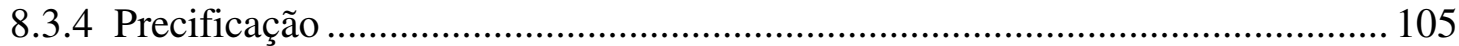

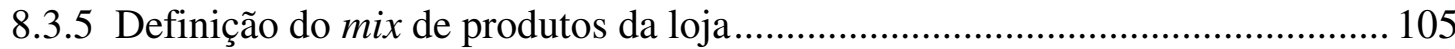

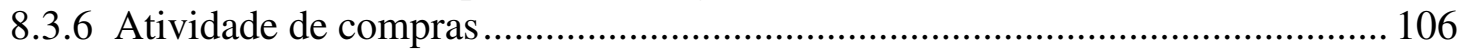

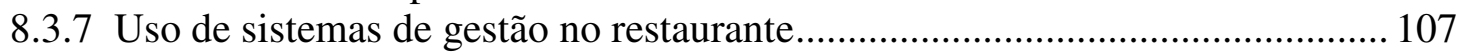

8.3.8 Formação e gerenciamento da equipe do restaurante.......................................... 107

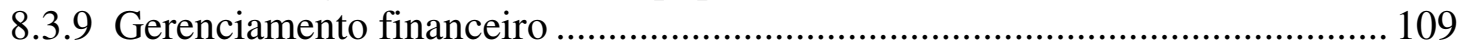

8.3.10 Alocação dos direitos de decisão: quadro geral ......................................... 110

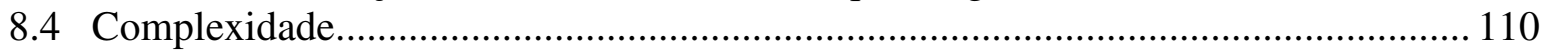

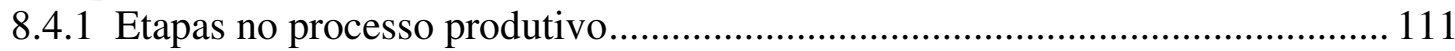

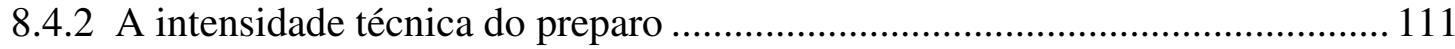

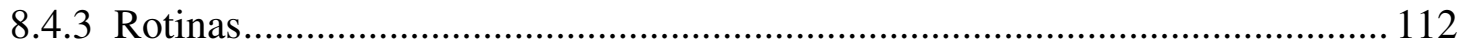

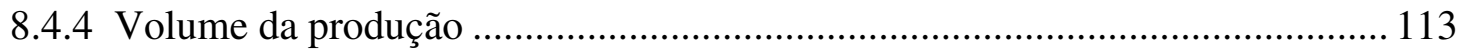

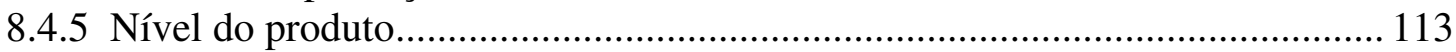

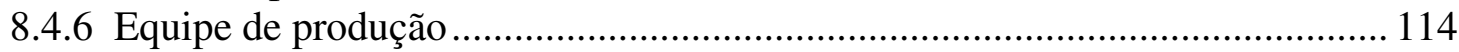

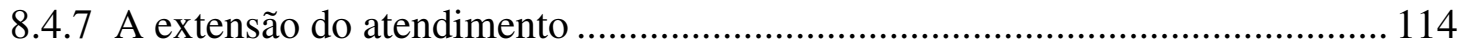

8.4.8 A estrutura de atendimento ........................................................................ 115

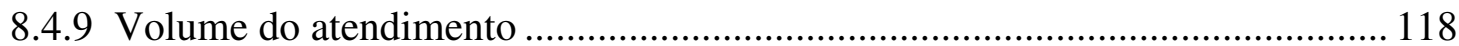

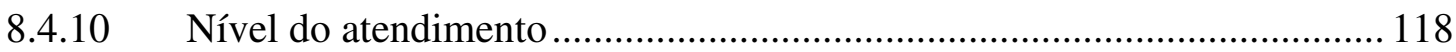

8.4.11 A equipe de atendimento .......................................................................... 118

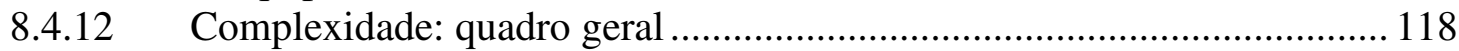

8.5 A governança da relação entre a Máster Franquia e seus restaurantes ......................... 119

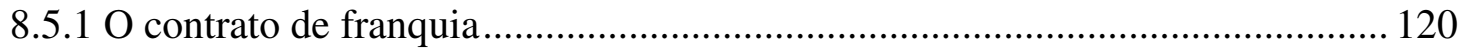

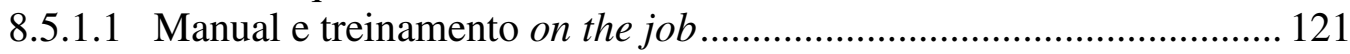

8.5.1.2 Inspeção informal via equipe de operações........................................... 121

8.5.1.3 Inspeções formais via equipe de operações.......................................... 122

8.5.1.4 Atenção da equipe de operações como medida de performance da

Máster Franquia aos franqueados.................................................................... 122

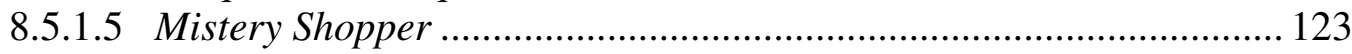

8.5.1.6 Acompanhamento do fluxo de compras.............................................. 123

8.5.1.7 Monitoramento via taxa de royalties.................................................. 124

8.5.1.8 Monitoramento via lançamentos contábeis ......................................... 124

8.5.1.9 Monitoramento do esforço da Máster Franquia via elaboração de

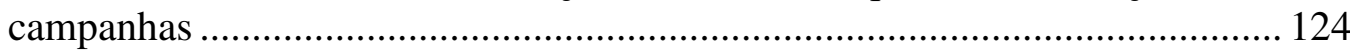

8.5.1.10 Cultura interna forte como mecanismo de enforcement ...................... 125

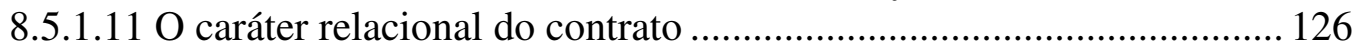

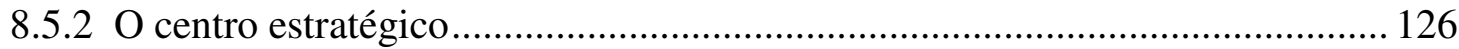

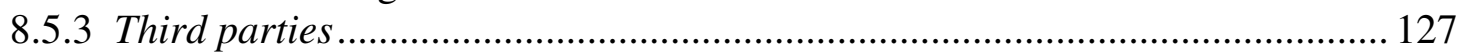

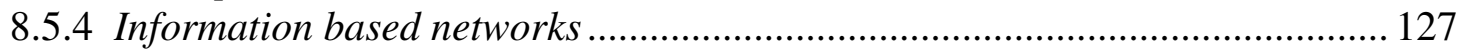

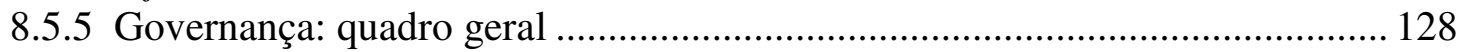

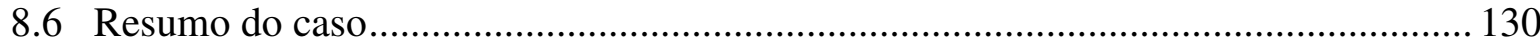

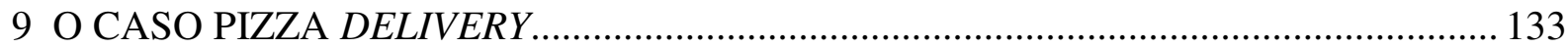

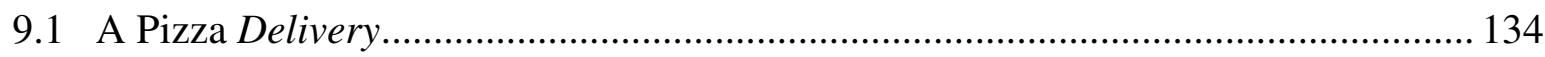

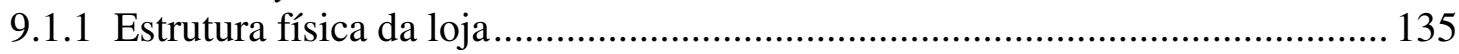

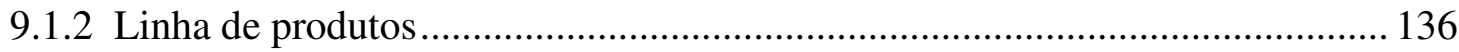

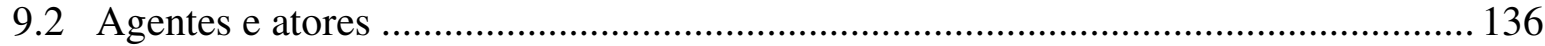




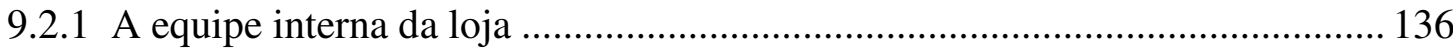

9.2.2 A equipe dedicada na Franqueadora ....................................................... 138

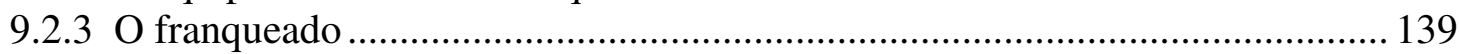

9.2.3.1 O processo de escolha do franqueado .......................................... 141

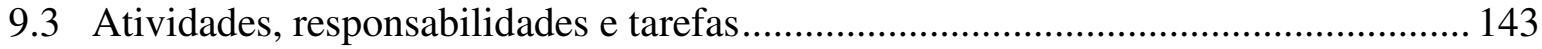

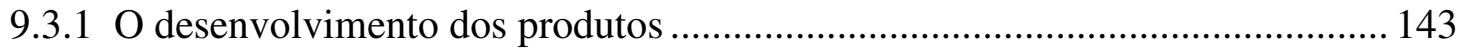

9.3.2 O desenvolvimento e veiculação de promoções e propaganda ....................... 145

9.3.3 A expansão da rede e a escolha do ponto comercial .................................... 146

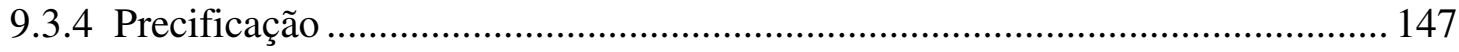

9.3.5 Definição do mix de produtos da loja....................................................... 148

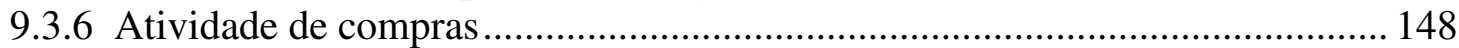

9.3.7 Uso de sistemas de gestão no restaurante................................................. 149

9.3.8 Formação e gerenciamento de equipe .................................................... 150

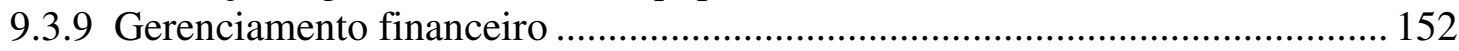

9.3.10 Alocação dos direitos de decisão: quadro geral .................................... 152

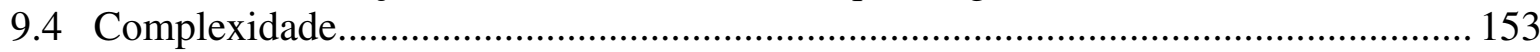

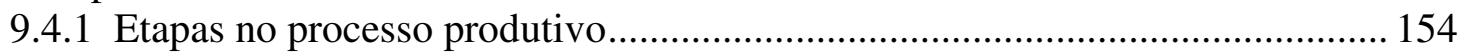

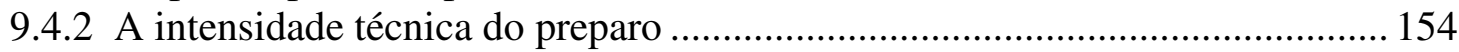

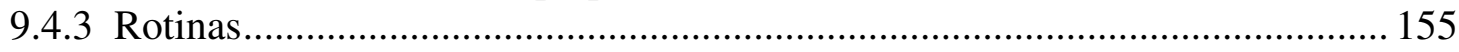

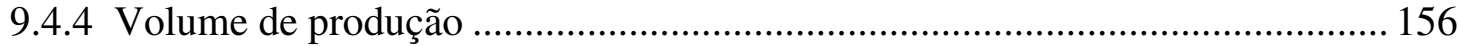

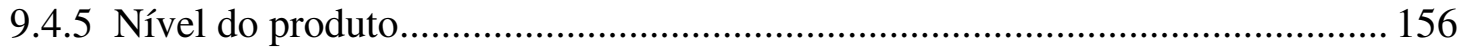

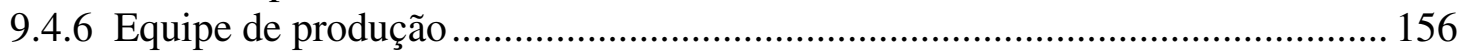

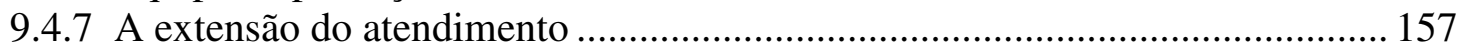

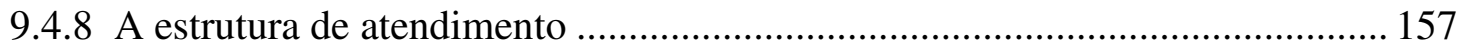

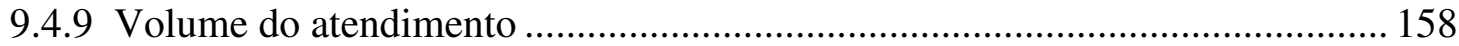

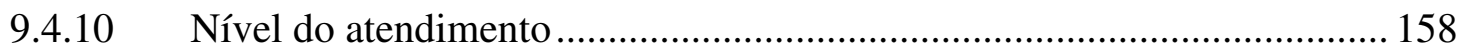

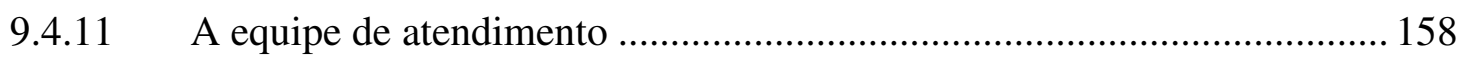

9.4.12 Complexidade: quadro geral ............................................................ 158

9.5 A governança da relação entre a Franqueadora e suas lojas .................................. 159

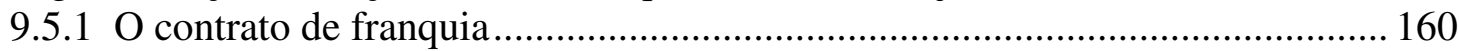

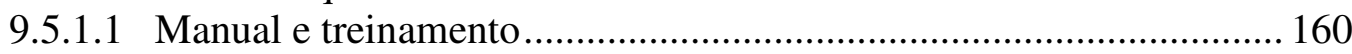

9.5.1.2 Inspeções formais via equipe de operações.................................... 161

9.5.1.3 Inspeção informal via equipe de operações..................................... 162

9.5.1.4 Atenção da equipe de operações como medida de performance da franqueadora para franqueados ............................................................ 162

9.5.1.5 Mistery Shopper ...................................................................... 162

9.5.1.6 Acompanhamento do fluxo de compras ........................................ 162

9.5.1.7 Monitoramento via acompanhamento de vendas ............................ 163

9.5.1.8 Monitoramento via taxa de royalties................................................ 163

9.5.1.9 Monitoramento do esforço da franqueadora via elaboração de

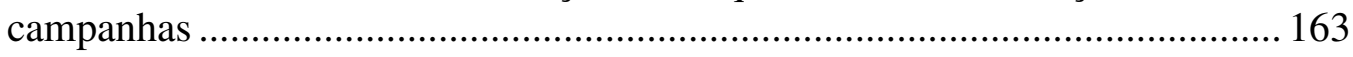

9.5.1.10 Cultura Interna como mecanismo de enforcement .......................... 163

9.5.1.11 O caráter relacional do contrato .................................................... 164

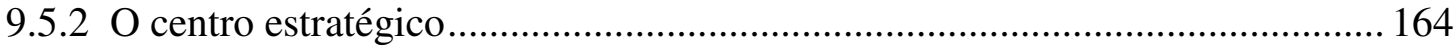

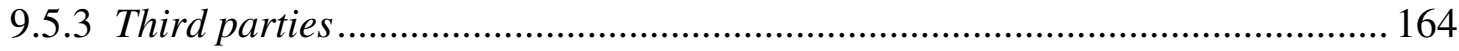

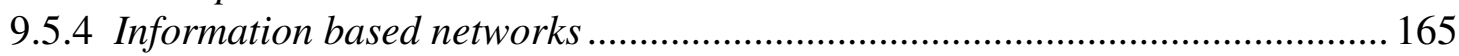

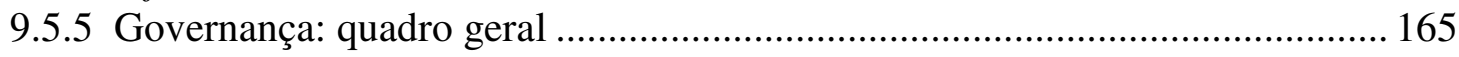

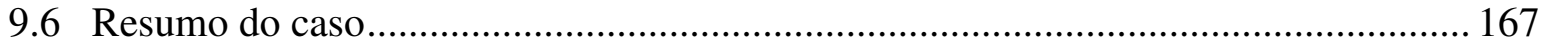

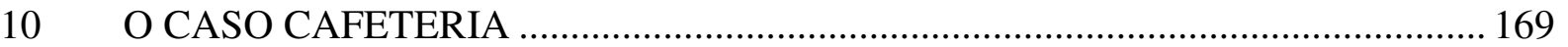




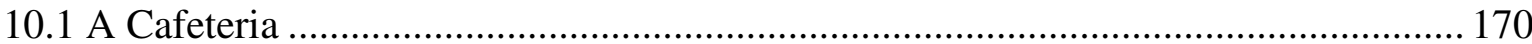

10.1.1 A estrutura física da loja ..................................................................... 171

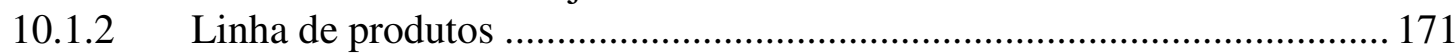

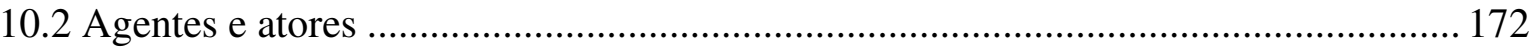

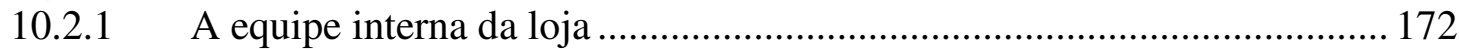

10.2.2 A equipe dedicada na Máster Franquia....................................................... 173

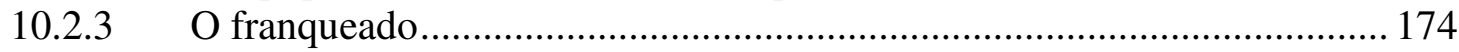

10.2.3.1 O processo de escolha do franqueado ............................................... 176

10.3 Atividades, responsabilidades e tarefas............................................................... 176

10.3.1 O desenvolvimento dos produtos ........................................................... 176

10.3.2 O desenvolvimento e veiculação de promoções e propaganda.................... 177

10.3.3 A expansão da rede e a escolha do ponto comercial................................... 178

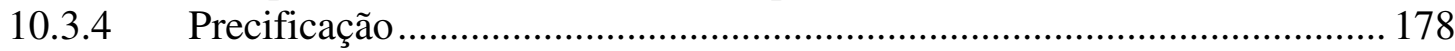

10.3.5 Definição do mix de produtos da loja ..................................................... 178

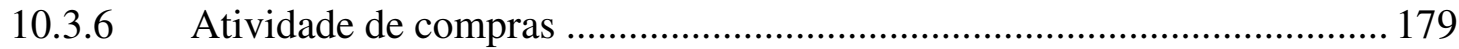

10.3.7 Uso de sistemas de gestão no restaurante ................................................... 180

10.3.8 Formação e gerenciamento de equipe ........................................................ 180

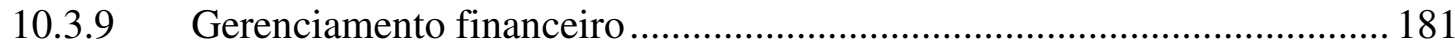

10.3.10 Alocação dos direitos de decisão: quadro geral ........................................ 181

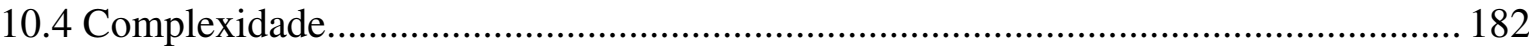

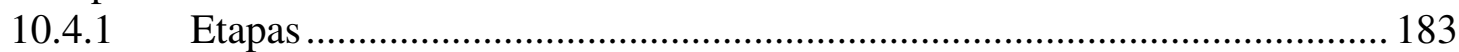

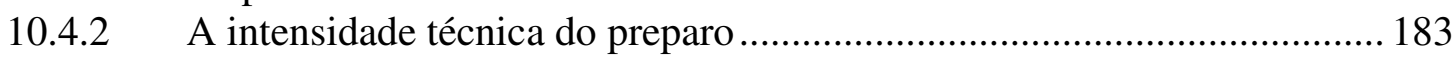

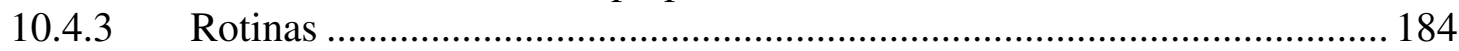

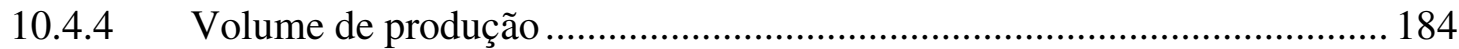

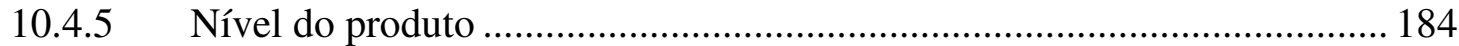

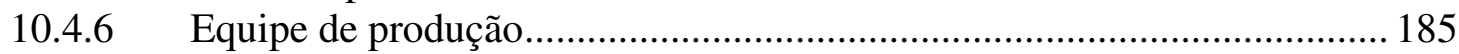

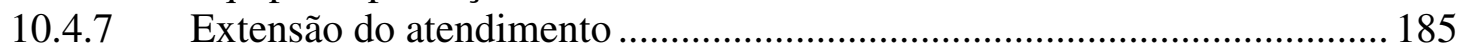

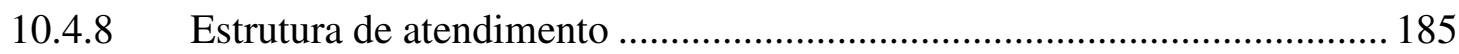

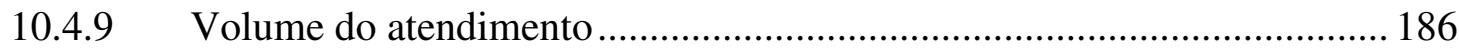

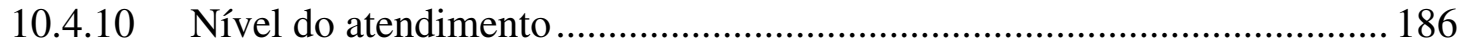

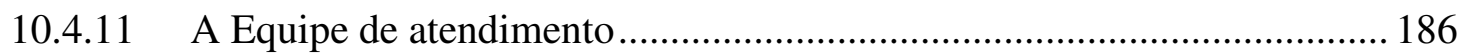

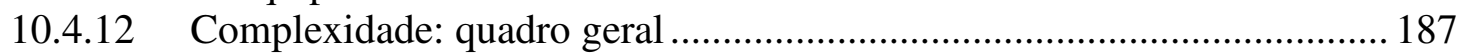

10.5 A Governança da relação entre a Máster Franqueadora e suas lojas ........................... 188

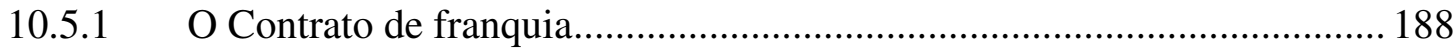

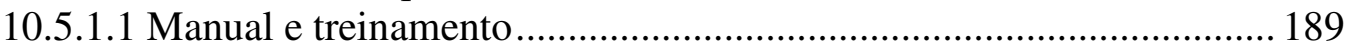

10.5.1.2 Inspeções formais via equipe de operações........................................ 189

10.5.1.3 Inspeção informal via equipe de operações.......................................... 190

10.5.1.4 Atenção da equipe de operações como medida de performance da

franqueadora para franqueados ..................................................................... 190

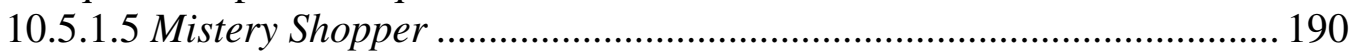

10.5.1.6 Acompanhamento do fluxo de compras............................................ 191

10.5.1.7 Monitoramento via acompanhamento de vendas ................................. 191

10.5.1.8 Monitoramento via taxa de royalties..................................................... 191

10.5.1.9 Monitoramento do esforço da franqueadora via elaboração de

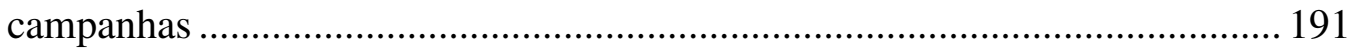

10.5.1.10 Cultura interna como mecanismo de enforcement ......................... 192

10.5.1.11 O caráter relacional do contrato.................................................. 192

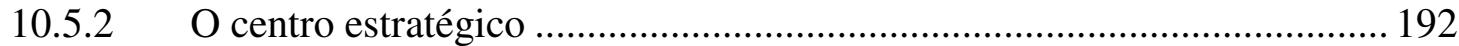

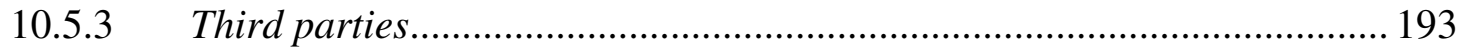

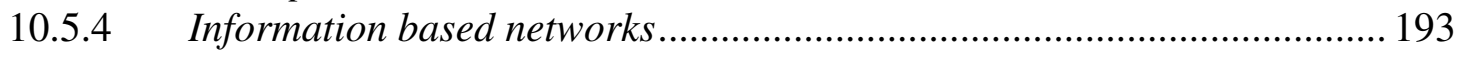




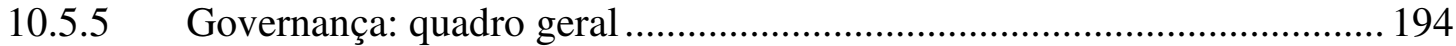

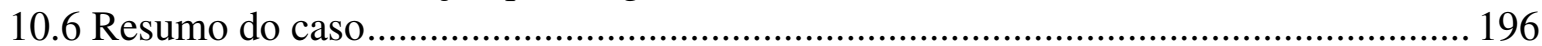

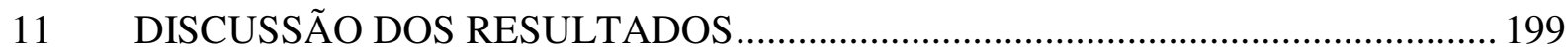

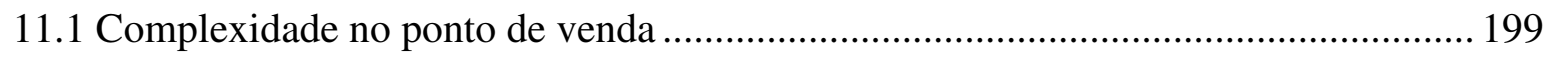

11.1.1 Marketing de vizinhança e delivery ................................................... 202

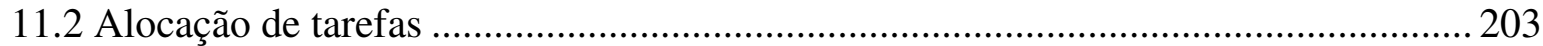

11.2.1 Esvaziamento e mecanismos complementares .................................... 205

11.3 Os mecanismos de governança à luz do modelo de Ménard (2010) ......................... 205

11.4 Controle efetivo e grau de adesão ao sistema .................................................. 207

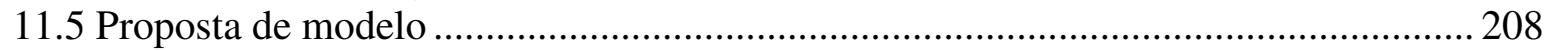

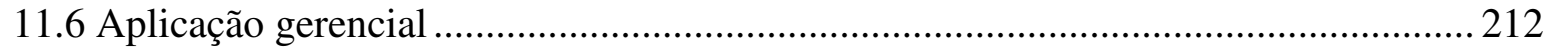

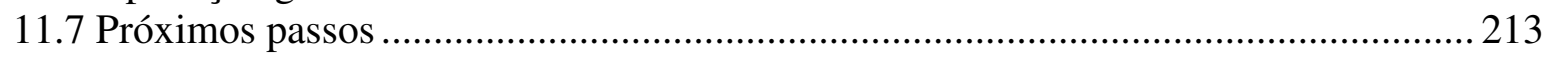

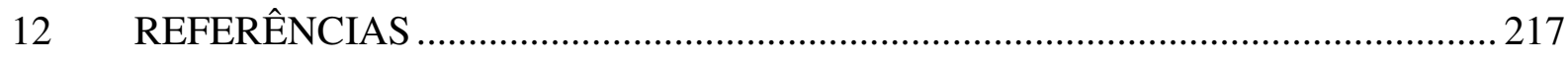

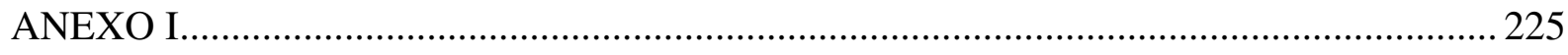

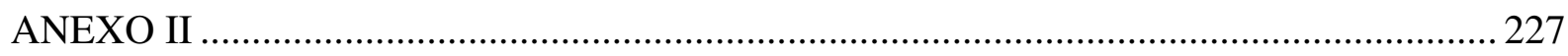

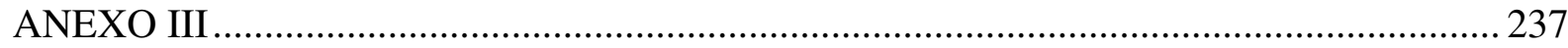




\section{LISTA DE ABREVIAÇÕES}

\begin{tabular}{|c|c|}
\hline $\mathrm{CF}$ & Contrato de fornecimento \\
\hline CFR & Contrato de franquia \\
\hline CL & Contrato de locação \\
\hline CLI & Contrato de licenciamento \\
\hline CMF & Contrato de máster franquia \\
\hline CORS & Center for Organizational Studies \\
\hline CPS & Contrato de prestação de serviço (operação de varejo) \\
\hline $\mathrm{CPV}$ & Complexidade no Ponto de Venda \\
\hline $\mathrm{CS}$ & Contrato de sociedade (joint venture) \\
\hline $\mathrm{CT}$ & Contrato de trabalho (vínculo empregatício) \\
\hline $\mathrm{CV}$ & Contrato de venda (spot) \\
\hline $\mathrm{CV}^{-}$ & Contrato de venda (intermediado por distribuidor logístico) \\
\hline DRE & Demonstrativo de Resultado \\
\hline ECT & Economia dos Custos de Transação \\
\hline FSR & Full Service Restaurants \\
\hline GH\&M & Grossman, Hart e Moore \\
\hline NEI & Nova Economia Institucional \\
\hline LSR & Limited Service Restaurants \\
\hline
\end{tabular}




\section{LISTA DE FIGURAS}

Figura 1 - Ativos Específicos e Custo de Governança............................................................ 21

Figura 2 - Relação de variáveis no Modelo de 2004 ............................................................... 38

Figura 3 - Uma tipologia para Formas Híbridas ................................................................... 43

Figura 4 - Contrastando Formas de Organização ………………………………………....... 45

Figura 5 - Tipologia de Formas Híbridas (2010) ………...................................................... 50

Figura 6 - Relação de variáveis no Modelo de 2010............................................................... 51

Figura 7 - Dipersão de Direitos de Propriedade (Pooling Resources) - Parte I........................ 52

Figura 8 - Dispersão de Direitos de Propriedade (Pooling Resources) - Parte II...................... 53

Figura 9 - Dispersão de Direitos de Propriedade (Pooling Resources) - Parte III ................... 54

Figura 10 - Dispersão de Direitos de Propriedade (Pooling Resources) - Parte IV ................. 55

Figura 11 - A cadeia produtiva alimentícia ........................................................................... 57

Figura 12 - Categorias (segmentos) em food service ……........................................................5

Figura 13 - Índice de Delegação de Autoridade..................................................................... 70

Figura 14 - Complexidade no ponto de venda ……………................................................. 75

Figura 15 - A influência das variáveis no constructo de CPV ............................................... 78

Figura 16 - Alocação de tarefas básicas em arranjos franqueados.............................................. 84 
Figura 17 - Organogarama do restaurante (Hamburgeria) ................................................ 98

Figura 18 - A equipe de contato da máster franquia (operações) ....................................... 100

Figura 19 - Alocação dos direitos de decisão na Hamburgeria (quadro geral) ...................... 110

Figura 20 - A complexidade no ponto de venda da Hamburgeria ...................................... 119

Figura 21 - Mecanismos de governança complementares associados à Hamburgeria .......... 129

Figura 22 - Organogarama de uma loja da Pizza Delivery ............................................. 137

Figura 23 - Organograma da equipe dedicada na franqueadora da Pizza Delivery .............. 139

Figura 24 - Alocação dos direitos de decisão na Pizza Delivery (Quadro Geral) .................. 153

Figura 25 - A complexidade no ponto de venda da Pizza Delivery ................................... 159

Figura 26 - Mecanismos de governança complementares associados à Pizza Delivery ........ 166

Figura 27 - A equipe dedicada na Máster Franquia da Cafeteria..................................... 173

Figura 28 - Alocação dos direitos de decisão na Cafeteria (quadro geral) .......................... 182

Figura 29 - A complexidade no ponto de venda da Cafeteria .......................................... 187

Figura 30 - Mecanismos de governança complementares associados à Cafeteria ................. 195

Figura 31 - Proposta de modelo para a relação entre CPV e centralização (parte 1)............ 209

Figura 32 - Proposta de modelo para a relação entre CPV e centralização (parte 2) ............. 210

Figura 33 - Proposta de modelo para a relação entre CPV e centralização (parte 3) ............ 211 


\section{LISTA DE GRÁFICOS}

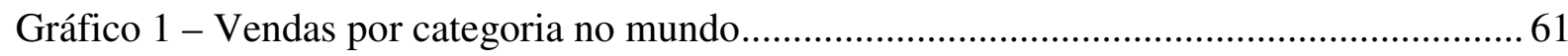

Gráfico 2 - Atividades do franqueado da Pizza Delivery ............................................... 141 


\section{LISTA DE QUADROS}

Quadro 1 - Estruturas e Mecanismos de Governança ...................................................... 24

Quadro 2 - Principais operadoras de food service ............................................................. 58

Quadro 3 - Mecanismos de governança do modelo de Ménard (2010) e centralização .......... 82

Quadro 4 - Mecanismos de governança e centralização para China in Box e Vivenda do

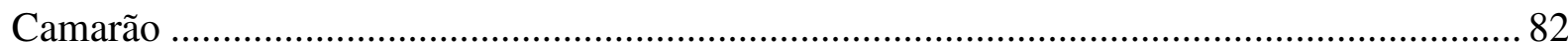

Quadro 5 - Mecanismos de governança principais da Hamburgeria .................................. 128

Quadro 6 - Resumo esquemático do Caso Hamburgeria ................................................. 130

Quadro 7 - Mecanismos de governança principais da Pizza Delivery ................................. 165

Quadro 8 - Resumo esquemático do Caso Pizza Delivery ............................................... 167

Quadro 9 - Mecanismos de governança principais da Cafeteria ......................................... 194

Quadro 10 - Resumo esquemático do Caso Cafeteria...................................................... 196

Quadro 11 - Comparação da CPV entre os casos............................................................ 199

Quadro 12 - Comparação do tamanho das equipes entre os casos ..................................... 200

Quadro 13 - Comparação da alocação de tarefas básicas entre os casos ............................. 203

Quadro 14 - Comparação da ocorrência dos mecanismos de governança do modelo de Ménard

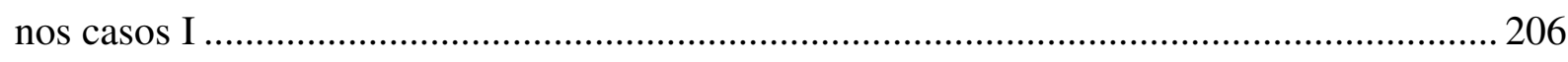

Quadro 15 - Comparação da ocorrência dos mecanismos de governança do modelo de Ménard nos casos II. 206 


\section{INTRODUÇÃO}

As organizações são o objeto de estudo de várias áreas do conhecimento das ciências sociais aplicadas. Este trabalho pretende focar o estudo das organizações pela ótica econômica, mais especificamente pela ótica econômica neoinstitucionalista.

Adotando-se esta visão econômica, pretende-se examinar as organizações inseridas em cadeias de valor e que adotam estruturas de governança híbridas. Para o pensamento neoinstitucionalista, formas híbridas podem ser entendidas como o conjunto de formas organizacionais usadas como estrutura de governança além do mercado e da hierarquia (WILLIAMSON, 1991; MÉNARD, 2004; MÉNARD 2010).

Formas híbridas também podem ser definidas a partir de suas características. Ménard (2010, p.2) as define como "arranjos entre firmas, em que os agentes compartilham uma série de direitos de decisão e direitos de propriedade, enquanto conservam sua independência e posse de outros ativos". Para Ménard, arranjos como: o franchising, o supply chain, as joint ventures, as redes, os cluster e as cooperativas são todos formas híbridas.

O presente trabalho pretende examinar especificamente a forma híbrida franchising, visando entender a dinâmica de sua incidência no setor da alimentação fora do lar. Conforme aponta a Euromonitor (2011; 2012), o franchising é a principal opção organizacional quando se trata de cadeias de lojas (restaurantes) neste setor.

Nesta discussão, o foco será dado pela busca de resposta para o seguinte problema de pesquisa:

O que determina a alocação de autoridade em cadeias de franquias no setor de food service?

Para responder a este problema de pesquisa elegeu-se a linha teórica desenvolvida por Claude Ménard $(2004 ; 2010)$ para o estudo das formas híbridas, pois o autor sugere um modelo de análise que incorpora a discussão da alocação de autoridade em arranjos híbridos. Utilizando este ferramental, será discutida a proposição de que: quanto maior a complexidade no ponto de venda de cadeias franqueadas (lojas que demandam grande esforço operacional ${ }^{1}$ ), maior a

\footnotetext{
${ }^{1} \mathrm{O}$ termo complexidade no ponto de venda será definido em mais detalhes no Capítulo 7.
} 
descentralização do arranjo.

A rigor, o objetivo final desta análise será propor um modelo econômico ${ }^{2}$ sobre o que estaria determinando a escolha de forma organizacional feita pelos agentes do setor, ou seja, o que estaria determinando a alocação de autoridade (grau de centralização) em cadeias franquiadas, no setor de alimentação fora do lar no Brasil.

Para alcançar tal objetivo, o trabalho está estruturado da seguinte forma:

Após esta introdução, será apresentada uma revisão do aporte teórico neoinstitucionalista, focando nos pontos relevantes à compreensão do modelo para análise de formas híbridas de Ménard (2010).

Em seguida, nos Capítulos 3 e 4, o modelo de análise de Ménard será apresentado, abrindo espaço para a compreensão da evolução desta linha teórica, a partir do trabalho inicial do autor em 2004.

O passo seguinte será apresentar um retrato do setor de food service, a partir de informações secundárias, que será feito no Capítulo 5.

Tendo definido as base teóricas, uma revisão específica sobre a forma como a teoria neoinstitucionalista trata o tema do franchising, será apresentada no capítulo seguinte (6). A seguir, no Capítulo 7, será discutida a proposta de análise da alocação de autoridade em cadeias franqueadas no setor de food service, elaborada com base no trabalho de Ménard. Os três capítulos posteriores (8, 9 e 10) são dedicados a apresentar os resultados obtidos da aplicação do estudo de múltiplos casos (uma hamburgueria, uma cafeteria e uma pizza delivery), sugerido na proposta de análise vista no Capítulo 7.

Por fim, após os casos, uma discussão dos resultados será apresentada no Capítulo 11, culminando com a sugestão de um modelo que retrate os determinantes da alocação de autoridade em redes de franquia no setor de food service.

\footnotetext{
${ }^{2}$ Deve-se esclarecer que o termo 'modelo econômico' usado na proposição do objetivo deste trabalho refere-se a um 'modelo de racionalidade econômica'e não a um 'novo modelo para a economia'.
} 


\section{APORTE TEÓRICO}

O neoistitucionalismo, que sustenta o modelo de Ménard (2010), é uma vertente da teoria econômica. Diferente da visão clássica sobre a firma, que a enxerga como uma função de produção e não tem como objetivo qualificar seu conteúdo, a Nova Economia Institucional (NEI) dá ampla importância às características e diferenças entre as firmas e sua influência no desempenho econômico. $\mathrm{O}$ arcabouço teórico neoinstitucional permite entender a racionalidade dos limites da firma ao propor um modelo de análise das relações entre as organizações que pertencem a uma cadeia de valor. A análise da evolução dessa abordagem é o que se propõe neste tópico, que pretende debruçar sobre os desenvolvimentos recentes que tratam dos arranjos híbridos.

\subsection{A firma e o mercado como alternativas de governança}

No início do século passado, em 1937, Coase publicou o que veio a ser um dos $\operatorname{artigos}^{3}$ mais influentes da teoria econômica. Discutindo a preocupação clássica entre comprar ou fazer (make or buy), Coase sugeriu que a firma e o mercado deveriam ser encarados como estruturas alternativas de governança. Para Coase, mantendo-se a mesma base tecnológica, surgiria uma diferença de custos ao comparar essas duas opções de produção, e o agente econômico acabaria por optar pela alternativa menos custosa.

Coase não especificou que custos seriam esses, nem os tipificou. Também não foi Coase que passou a chamar tais custos de Custos de Transação ${ }^{4}$. A contribuição de Coase foi mostrar que mercado e firma são alternativas de produção e de que para cada uma destas alternativas há um custo diferente.

\footnotetext{
${ }^{3}$ The nature of the firm (1937).

${ }^{4} \mathrm{O}$ termo passou a receber essa denominação a partir da releitura dos trabalhos de Coase por Williamson (1975; $1985 ; 1991)$.
} 


\subsection{Williamson e a Economia dos Custos de Transação}

A partir da proposta de Coase, Williamson deu uma contribuição fundamental para o desenvolvimento da NEI. Williamson $(1975 ; 1985 ; 1991)$ conseguiu formular uma proposta (modelo teórico) em que os tais custos identificados por Coase, agora chamados de custos de transação, deveriam variar conforme os atributos da transação: frequência, especificidade dos ativos e incerteza. Desta forma, à medida que a firma optasse por determinada forma de governança para minimizar os custos de transação a serem incorridos, ela estaria alinhando sua opção de governança aos tais atributos da transação.

Williamson (1996, p. 379) desenvolveu seu modelo conceituando custos de transação da seguinte forma:

Os custos ex-ante de delinear, negociar e salvaguardar um acordo e, mais ainda, os custos ex-post de maladaptação e ajuste que ocorrem quando a execução dos contratos fica desalinhada como resultado de erros, omissões e problemas não antecipados 5 .

Para entender melhor o modelo de Williamson, vale percorrer alguns pontos teóricos. Para tanto, deve-se rever os pressupostos comportamentais adotados pelo autor, observar a unidade de análise de sua proposta e, por fim, discutir em mais detalhes o mecanismo de alinhamento sugerido por ele.

\subsubsection{Pressupostos comportamentais}

O trabalho de Williamson foi altamente influenciado por Herbert Simon (WILLIAMSON, 1996). É desta influência que Williamson assume em seu trabalho que duas características fundamentais da natureza humana deveriam ser consideradas para caracterizar o agente econômico: sua capacidade cognitiva e sua preocupação consigo mesmo (autointeresse). Da questão cognitiva evolui o conceito de Racionalidade Limitada e, do autointeresse, o conceito de Oportunismo, conforme apresentado a seguir.

\footnotetext{
${ }^{5}$ Nas palavras do autor: "The ex-ante costs of drafting, negotiating, and safeguarding an agreement and, more especially, the ex-post costs of maladaptation and adjustment that arise when contract execution is misaligned as a result of gaps, errors, omissions, and unanticipated disturbances" (WILLIAMSON, 1996, p. 379).
} 


\subsubsection{Racionalidade Limitada}

Como relata o próprio Williamson (1996), ele não foi influenciado apenas pelos trabalhos de Simon, mas também pela convivência com a pessoa do professor e pesquisador na Carnegie Mellon, enquanto era aluno de pós-graduação. Na Carnegie Mellon, Simon conduzia um grupo de pesquisa sobre a natureza do comportamento humano, que culminou com a proposta de que o agente econômico não deveria ser visto como uma entidade capaz de lidar plenamente com a informação recebida. Nesta nova visão, o agente teria a intenção de agir racionalmente, mas sua performance seria limitada, o que difere da visão clássica de racionalidade plena (ou hiper-racionalidade) (SIMON, 1947; SIMON, 1957).

Ao usar o conceito de Racionalidade Limitada, deve-se lembrar de que a limitação vem da estrutura cognitiva do agente e que, desta forma, pode-se considerar cada agente como entidade única.

Uma das principais características da Economia dos Custos de Transação (ECT) de Williamson, e da NEI como um todo, é a visão de que os contratos serão sempre incompletos. Mesmo no caso de os agentes gastarem grande esforço na elaboração do contrato, ele sempre será incompleto e não será possível prever todas as possibilidades de problemas contratuais ex-post. Como explica Williamson (2001, p. 6691), é a racionalidade limitada do agente que conduz a este resultado.

Discutindo um pouco mais a influência da Racionalidade Limitada e da Incompletude Contratual na Economia dos Contratos, vale resgatar o conceito introduzido por Llewellyn (1931) de que os contratos deveriam ser vistos como uma estrutura (framework) capaz de guiar os ajustes necessários na condução das transações. O insight de Llewellyn, fruto da adoção da Racionalidade Limitada como pressuposto comportamental, é uma das bases do conceito de Contratos Relacionais, desenvolvido mais tarde por MacNeil (1974; 1978), e peça fundamental do modelo de Ménard (2010). O tema de Contratos Relacionais será retomado em mais detalhes na Seção 2.2.4. 


\subsubsection{Oportunismo}

A segunda característica que compõe a natureza do agente econômico apontado por Williamson é o autointeresse. Nessa perspectiva, o agente econômico presta-se, em alguns momentos, a agir ativamente em seu benefício próprio, ou seja, oportunisticamente. Pesando sempre os custos e benefícios de seus atos, o agente poderá agir até de maneira antiética para satisfazer seu autointeresse (WILLIANSON, 1996). O oportunismo é o cerne do problema de hold-up ${ }^{6}$, uma das principais fontes de custos de transação. Após o mecanismo básico de alinhamento e da ECT serem apresentados, será discutido, em mais detalhes, o problema de hold-up.

\subsubsection{A transação como unidade de análise}

Após assumir os pressupostos comportamentais, Williamson (1996) definiu a transação como unidade de análise para sua proposta de Teoria da Firma. Influenciado pelo trabalho de Commons (1932), Williamson definiu a transação como unidade de análise, pois ela permitia compreender as decisões tomadas na firma. Para Williamson é a capacidade de conter as características de mutualidade, conflito e ordem (apontadas por Commons, anteriormente) que faz da transação a unidade de análise ideal (WILLIAMSON, 1996).

\subsubsection{Alinhamento e ECT}

Conforme apresentado no início da Seção 2.2, o ponto fundamental do trabalho de Williamson $(1991$; 1996) foi identificar atributos da transação que pudessem caracterizá-la e, ao mesmo tempo, indicar qual seria a relação destes atributos com a ocorrência dos custos de transação, que levaria a escolha eficiente de governança. Dando este passo, Williamson (1991; 1996) conseguiu operacionalizar a visão apresentada por Coase (1937) de que a firma atua como uma entidade minimizadora de custos de transação.

\footnotetext{
${ }^{6} \mathrm{O}$ conceito será visto em detalhes na Seção 2.2.3.1.
} 
Em 1991, Williamson publicou o modelo que vinha desenvolvendo desde o início de sua pesquisa e que lhe valeu o Nobel em 2009. Neste modelo, o autor identificou a especificidade dos ativos, a frequência e a incerteza como os atributos capazes de retratar a transação. Em seu modelo, a especificidade dos ativos e a incerteza influenciariam positivamente a ocorrência de custos de transação, enquanto a influência da frequência seria no sentido oposto.

Para visualizar o que vem a ser o alinhamento entre os atributos da transação e a estrutura de governança ideal, ou seja, a estrutura minimizadora de custos de transação, vale observar o modelo desenvolvido por Williamson (1991, p. 284) que ilustra a relação entre a especificidade dos ativos e o custo de governança apresentado a seguir na Figura $1^{7}$.

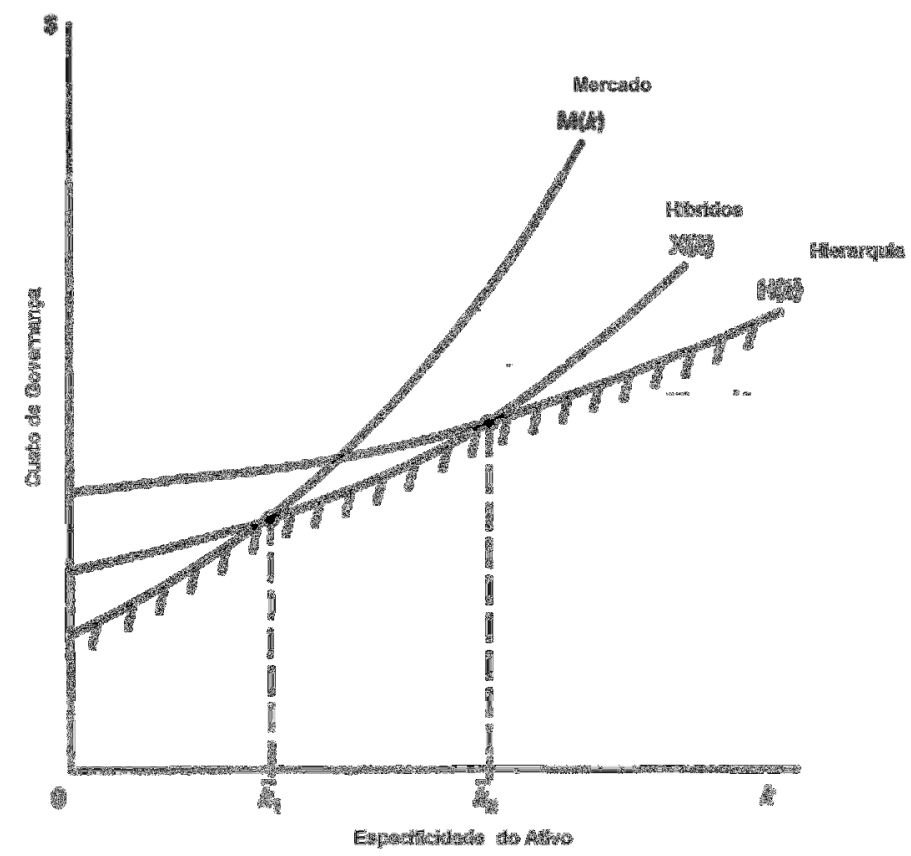

Figura 1 - Ativos Específicos e Custo de Governança

Fonte: Williamson, 1991, p. 284 (traduzido para a Língua Portuguesa pelo autor)

De acordo com o modelo proposto por Williamson (1991), na ocorrência de baixa especificidade de ativos, a opção que minimiza o custo de governança é o mercado. Para especificidades intermediárias, a opção minimizadora é a forma híbrida e para incidência de alta especificidade de ativos, o ideal é fazer uso da hierarquia.

\footnotetext{
${ }^{7}$ A versão original em inglês da Figura 1 está disponível no Anexo III.
} 
Com relação ao atributo frequência ${ }^{8}$, para Williamson (1991), em interações recorrentes, os custos de se contratar e monitorar determinada transação estariam diluídos devido às várias repetições da referida transação, fazendo do atributo frequência uma variável de influência negativa na ocorrência de custos de transação.

Sobre a incerteza, Williamson (1991) deixa claro que está se referindo ao conceito trazido por Knight (1972) sobre eventos para os quais não se pode prever a ocorrência, algo distinto do conceito de risco, que se refere a eventos cuja probabilidade de ocorrência pode ser modelada.

Sendo a especificidade dos ativos o atributo de maior relevância no modelo de Williamson (1991), observa-se que as firmas tornam-se susceptíveis a ações de seus parceiros, ao se defrontarem com graus não desprezíveis de especificidade, como discutido a seguir.

\subsubsection{Especificidade dos ativos, quase-renda' e o problema de hold-up}

Para compreender o que está envolvido no conceito de especificidade do ativo e o motivo que sua existência pode gerar custos de transação, é necessário entender o conceito correlato de quase-renda e o problema de hold-up.

Klein, Crawford e Alchian (1978) explicam que existem situações em que o retorno esperado do investimento de determinado agente econômico depende da ação de um segundo agente, com quem ele transaciona ${ }^{10}$. Em resumo, quando existe essa dependência, os investimentos podem ser chamados de específicos, pois são específicos àquela relação, e os ativos gerados por investimentos específicos devem ser chamados de ativos específicos. Havendo investimento específico, a relação entre os agentes poderá gerar quase-renda, que seria a diferença entre o retorno de um ativo em seu principal emprego e aquele que seria obtido em sua segunda melhor alternativa de uso (FARINA; AZEVEDO; SAES, 1997).

\footnotetext{
${ }^{8}$ Autores que consideram o efeito de self-enforcement (KLEIN; CROWFORD; ALCHIAN, 1978) acreditam que a busca por conservar e construir reputação influencia a diminuição dos custos de transação em relações recorrentes.

${ }^{9}$ Em inglês: quasi-rent.

${ }^{10}$ Williamson chama de Transformação Fundamental a transferência da atenção do agente econômico de sua relação com o mercado, para a sua relação com um único agente deste mercado (resultante da dependência).
} 
A principal consequência do investimento em ativos específicos é que, fora do âmbito que lhes confere especificidade, tais ativos perdem valor, ou seja, se for necessário realocar o investimento feito, qualquer segunda opção trará um retorno inferior ao obtido pelo investimento na relação inicial. O que está por trás do retorno extraordinário dos investimentos nessas situações é a complementaridade. Quando existe complementaridade na relação entre os agentes, pode-se esperar retornos extraordinários.

Devido à dependência do agente em relação à sua contraparte na geração da quase-renda, o agente que faz o investimento em ativos específicos acaba ficando susceptível a um eventual comportamento oportunista de seu parceiro, que pode tentar se aproveitar dessa dependência para tentar expropriar parte da quase-renda gerada. Tal comportamento oportunista é chamado de hold-up (KLEIN; CRAWFORD; ALCHIAN, 1978). Temendo o comportamento oportunista de seu parceiro, o agente acaba incorrendo em custos adicionais para se proteger de possíveis tentativas de expropriação. Conforme a definição apresentada no início da seção 2.2, tais custos são custos de transação.

A relação entre a especificidade dos ativos e o risco de oportunismo em relações contratuais (contractual hazards) permite o entendimento da forma pela qual o próprio Williamson (1996) define a ECT, como o processo de "identificação, explicação e mitigação dos riscos contratuais pela governança ${ }^{11,}$ (WILLIAMSON, 1996, p.14).

Williamson (1991) aponta seis tipos de especificidades de ativos que devem ser consideradas em qualquer análise: especificidade locacional, física, humana, de marca, temporal e de ativos dedicados (investimentos em um cliente específico).

\subsubsection{Mecanismos e estruturas de governança: esclarecendo a nomenclatura}

A Economia dos Custos de Transação trouxe uma possibilidade de análise empírica que foi muito bem-vinda na comunidade acadêmica. Foram inúmeros os trabalhos científicos derivados da aplicação do modelo de Williamson (MAHONEY, 2005). Consequentemente, a

${ }^{11}$ Nas palavras do Autor: "identification, explication, and mitigation of hazards through governance" (WILLIAMSON, 1996, p.14). 
nomenclatura usada para apontar as variáveis do modelo acabou recebendo um tratamento particular dos autores e pesquisadores que discutem a teoria da firma. Vale, portanto, repassar os casos mais comuns de nomenclatura usada para apontar as estruturas e os mecanismos de governança.

Conforme discutido anteriormente, o insight de Coase que dá início à ECT refere-se ao mercado e à firma como: alternative modes of organization (COASE, 1937, p. 386). O próprio Coase, em 1992, já se refere às estruturas de governança por institutional structure[s] of production (COASE, 1992, p. 713).

Já considerando as organizações híbridas como uma alternativa ao mercado e à hierarquia, Williamson (1996, p. 4) refere-se a elas usando o termo: institutions of governance. Ménard, por sua vez, usa termos como: modes of organization (2004, p. 354), mecanismos de coordenação (2004, p. 348) e estruturas de governança (2004, p. 368) como sinônimos. Williamson (1996, p. 378) também adota o termo estrutura de governança, e o define como: "o arcabouço institucional em que a transação é definida" ${ }^{12,}$. Neste momento, fica sendo relevante diferenciar dois conceitos: o de Estrutura de Governança e o de Mecanismo de Governança, para evitar confusão devido à existência de sinônimos usados na literatura.

Mecanismos de Governança, conforme o título da obra de Williamson de 1996, The Mechanisms of Governance, refere-se ao principal mecanismo usado para coordenar as transações em cada caso particular de [estrutura de] governança. Sendo assim, o mecanismo de governança usado pelo mercado seria o sistema de preços, o mecanismo usado por formas híbridas seria o contrato e o mecanismo usado pela hierarquia seria a autoridade, conforme ilustra o Quadro 01 apresentado a seguir.

\begin{tabular}{|c|c|}
\hline Estrutura de Governança & Principal Mecanismo de Governança \\
\hline Hierarquia (Integração Vertical) & Autoridade \\
\hline Forma Híbrida & Contratos \\
\hline Mercado & Sistema de Preços \\
\hline
\end{tabular}

Quadro 1 - Estruturas e Mecanismos de Governança

Fonte: elaborado pelo autor, com base em Williamson (1996)

12 Nas palavras do Autor: the institutional matrix in which the integrity of the transaction is decided" (WILLIAMSON, 1996, p. 378). 


\subsubsection{Contratos Relacionais}

Na seção anterior, ficou clara a importância dos contratos como principal mecanismo de governança utilizado por formas híbridas. Como Ménard (2010) valoriza fortemente a característica relacional dos contratos para construir seu modelo de análise, apresenta-se como pertinente uma breve revisão deste conceito nesta seção, para facilitar o entendimento do referido modelo nos capítulos seguintes.

Anteriormente, na seção 2.2.1.1, quando se discutiu o pressuposto comportamental de Racionalidade Limitada, foi introduzida a ideia que, devido a esta característica da natureza humana, os contratos acabam sendo sempre incompletos. Em 1931, Llewellyn já apontava o uso de contratos como estrutura (framework) geral para conduzir transações, em contraposição ao design de contratos detalhados ${ }^{13}$.

Percebendo a importância de elementos que não estavam presentes nos contratos, mas afetavam o andamento dos acordos mesmo assim, MacNeil (1974; 1978) introduziu o conceito de contractability e non-contractability. É importante perceber que estes conceitos vão além do que compreende o conceito de contrato formal e informal, pois os elementos não contratáveis estão ligados às expectativas dos agentes perante as suas relações contratuais, o que vai muito além de simplesmente estabelecer se determinada clausula é formal ou informal. Para compreender o conceito de Relational Contract, é necessário ter em mente a questão temporal e visualizar o que os agentes esperam conseguir ao longo do tempo. $\mathrm{O}$ conceito de contratos relacionais capta a influência de situações que envolvem decisões ligadas à presença de expectativas, de laços de confiança, de esperança e até da boa vontade dos agentes envolvidos numa transação.

Logo, considerando-se os elementos apresentados até agora, contratos relacionais seriam aqueles capazes de lidar de maneira mais eficiente com situações em que os acordos envolvem (muitos) elementos não contratáveis (non-contractables). Ménard (2010, p. 18) deixa claro que vê os contratos relacionais pela ótica econômica, ou seja, vê o agente econômico ponderando suas atitudes no presente em função de ganhos (ou perdas) no futuro.

\footnotetext{
${ }^{13} \mathrm{Na}$ literatura sobre franchising é muito comum encontrar relatos sobre essa forma de contratação (ver, por exemplo, BLAIR; LAFONTAINE, 2005).
} 
O autor salienta a importância da reputação (POPPO; ZENGER, 2002) como constructo capaz de traduzir uma série de elementos relevantes e non-contractables. Valorizando o constructo da reputação desta forma, Ménard novamente apresenta-se alinhado a Williamson (1985), que também tem essa visão sobre os contratos relacionais.

\subsection{Formas híbridas}

Tendo estabelecido a posição de importância que as formas híbridas ocupam como alternativa de governança na Economia dos Custos de Transação, pode-se detalhar um pouco mais suas características.

Há duas formas de caracterizar as formas híbridas: uma delas é expondo suas características, ou seja, tentando mostrar como elas são. A segunda é compreender seus contornos a partir da definição do que elas não são. Esta segunda forma de abordar o conceito de forma híbrida, estabelecendo uma contra definição, tem origem na análise discreta de formas organizacionais proposta pela ECT de Williamson (1991). De acordo com esta teoria, formas organizacionais diferentes da hierarquia e diferentes do mercado serão as chamadas formas híbridas. O termo usado é proposital, para indicar que estas formas carregam características de ambas as formas extremas do modelo, ou seja, têm elementos típicos do mercado e, ao mesmo tempo, elementos de hierarquia. Neste sentido, Ménard (2010, p. 4) define as formas híbridas como: “o conjunto dos relacionamentos entre empresas baseados numa coordenação diferente do mercado e da integração vertical ${ }^{14 \%}$.

A importância dessa discussão está centrada na possibilidade de tratar as formas híbridas como uma classe de estrutura de governança, formada por diferentes tipos de organizações, que mantêm características em comum. Nesta visão, estruturas como: subcontratação, franchising, redes de empresas, parcerias, cooperativas, clusters, supply chain, alianças, joint ventures e outras fazem parte de uma família de estruturas e têm características em comum. Ménard é um dos autores que enxerga as formas híbridas assim, como uma classe ou família de estruturas organizacionais e, desta forma, seu trabalho, ao caracterizar, analisar e tipificar

\footnotetext{
${ }^{14}$ Nas palavras do autor: "the richness of relationships among businesses resorting to means of coordination other than the price mechanism or direct integration." (MÉNARD, 2010, p. 4).
} 
as formas híbridas, traz sempre a preocupação de fazer isto dentro de um contexto (ou modelo) que retrate estas estruturas como um conjunto de formas com características comuns e passíveis de análise.

Ao comentar os pontos fundamentais de seu modelo de 2004, Ménard deixa clara sua preocupação com esta questão, apontando-a como 'proposição central' de seu trabalho. Nas palavras do autor: “... a questão central deste trabalho é que os arranjos híbridos formam uma classe específica de estruturas de governança ${ }^{15 ، ~(M E ́ N A R D, ~ 2004, ~ p . ~ 368) . ~}$

\subsubsection{Definição}

O conceito de forma híbrida está completamente ligado à evolução da ECT de Williamson. Na obra Markets and Hierarchies, publicada em 1975, Williamson definiu as formas híbridas como intermediate forms of contracting, sem colocá-las como uma alternativa de governança, pois o autor via essas formas organizacionais como instáveis.

Em 1985, no livro The Economic Institutions of Capitalism, Williamson passou a dar uma importância maior às formas híbridas ao verificar a relevância e extensão de sua ocorrência. No artigo Comparative economic organization: the analysis of discrete structural alternatives, de 1991, o modelo de Williamson já contava com o termo atual e já considerava as formas híbridas como uma opção à hierarquia e ao mercado.

Ménard (2004) resume o conteúdo do conceito na ocorrência de três características neste tipo de relacionamento: 1) Os participantes dos arranjos são legalmente autônomos; 2) A coordenação das atividades ligadas à interação dos participantes ocorre sem grande influência do sistema de preços; 3) As transações entre os agentes (troca de produtos, serviços e mesmo de tecnologia) ocorrem num ambiente onde a propriedade não é unificada.

Ménard (2004) explica que as formas híbridas devem ser vistas como acordos (arranjos) entre firmas. Para o autor, esses acordos ocorrem sempre em situações onde há certo grau de

\footnotetext{
${ }^{15}$ Nas palavras do autor: "...the central proposition of this paper [which] is that hybrid organizations form a specific class of governance structures...” (MÉNARD, 2004, p. 368).
} 
competição entre os agentes, existem investimentos específicos (interdependência) e existe algum uso da ferramenta contratual na relação (MÉNARD, 2004). Em seu artigo de 2010, o autor inclui elementos da Teoria dos Direitos de Propriedade em sua retórica e evolui para a seguinte definição (MÉNARD, 2010, p. 2):

formas híbridas podem ser definidas como arranjos em que dois ou mais parceiros disponibilizam um conjunto de direitos de decisão e direitos de propriedade ao arranjo, mantendo, ao mesmo tempo, a propriedade sobre outros ativos, necessitando de mecanismos específicos para coordenar a produção conjunta e alocar a renda gerada eficientemente ${ }^{16}$.

Ménard (2010) destaca que as atividades realizadas por intermédio de arranjos híbridos esbarram sempre numa situação em que os participantes são forçados a tomar decisões conjuntamente, pois ao aderirem ao arranjo, os participantes acabam cedendo alguns direitos de propriedade ao grupo. Em seguida, os integrantes dos arranjos passam a ter parte de seus direitos de propriedade resguardados, intactos (conservando autonomia sobre eles), e parte de seus direitos ligados ao restante do grupo, perdendo controle sobre eles, fazendo com que a decisão sobre essa fração só possa ocorrer a partir da concordância dos participantes. Nota-se que o autor escolheu a propriedade e o controle como as principais dimensões para caracterizar as formas híbridas. Esta escolha não é à toa, e está alinhada à maneira como muitos autores caracterizam a firma e, principalmente, está alinhada à forma como a ECT caracteriza a hierarquia. Tendo as formas híbridas características da hierarquia, conforme explicado na última seção, esta escolha de Ménard faz todo sentido.

Além de definir as formas híbridas em função da dispersão e alocação dos direitos de propriedade $^{17}$ dos integrantes destes arranjos, ao lançar sua definição, Ménard também indica os dois principais 'desafios' que deverão ser encarados ao se fazer a opção híbrida: a necessidade de mecanismos específicos para coordenar a atividade conjunta e a dificuldade de alocar eficientemente a renda gerada.

\footnotetext{
${ }^{16}$ Nas palavras do Autor: "hybrids can be defined as arrangements in which two or more partners pool strategic decision rights as well as some property rights, while simultaneously keeping distinct ownership over key assets, so that they require specific devices to coordinate their joint activities and arbitrate the allocation of payoffs" (MÉNARD, 2010, p. 2).

${ }^{17}$ Uma breve revisão sobre o conceito de Direitos de Propriedade será feita na Seção 2.5.
} 


\subsubsection{Motivação}

Uma forma de complementar o entendimento da definição de formas híbridas é entender a motivação dos agentes para usá-las como alternativa. A seguir, serão discutidos com um pouco mais de detalhe estes dois 'desafios' apontados por Ménard e sua influência sobre a opção pela alternativa híbrida mais eficiente.

\subsubsection{Coordenação de atividades conjuntas}

Williamson (2001) aponta como preocupação central no estudo da economia das organizações o fenômeno de adaptação. De acordo com ele, as trocas (transações) no mercado ocorrem de maneira autônoma (espontânea), com o auxílio do sistema de preços, conforme a posição clássica de Hayeck (1945). Já no ambiente híbrido, ou mesmo sob hierarquia, as transações somente ocorrem havendo cooperação entre os agentes, conforme a posição de Barnard (1932).

Williamson (1996) assume que o insight de Barnard (1932) sobre a necessidade de cooperação é uma das bases da ECT. É o próprio Barnard (1932) que indica a necessidade de 'processos administrativos' para viabilizar tal cooperação. Detalhando um pouco mais o que está envolvido na atividade produtiva, percebe-se que existe todo um esforço a ser feito para garantir um andamento harmônico entre os agentes quando há divisão de tarefas. Preocupações práticas com o estabelecimento de padrões de qualidade e quantidade e o delineamento de um cronograma conjunto podem ser exemplos típicos deste esforço. Além da harmonização da atividade produtiva, também existem preocupações com o monitoramento do que se espera dos agentes e esforços em estabelecer mecanismos que garantam o cumprimento dos acordos firmados.

Promover a coordenação da atividade produtiva é função da estrutura organizacional. Neste sentido, a maior motivação da opção por formas híbridas reside na capacidade dessas formas coordenarem determinado conjunto de transações de maneira mais eficiente (sob o menor custo) que o mercado ou a hierarquia. Segundo Ménard (2010) e sua definição de formas 
hibridas apresentada na seção anterior, a situações específica em que a coordenação eficiente ocorre é aquela em que "dois ou mais parceiros disponibilizam um conjunto de direitos de decisão e direitos de propriedade ao arranjo, mantendo, ao mesmo tempo, a propriedade sobre outros ativos $^{18, "}$ (MÉNARD, 2010, p. 2).

A questão de se preocupar e tentar impedir o eventual comportamento oportunista dos agentes é um ponto fundamental a ser gerido pela estrutura organizacional nos casos em que existe um compartilhamento de direitos de propriedade e, consequentemente, dependência entre os agentes na tomada de decisão. Nestes casos, há muito espaço para problemas de hold-up. Desta forma, a possibilidade de lidar com o oportunismo também pode ser apontada como uma das grandes motivações para a adoção de formas híbridas. Ménard (2004, p. 363) usa essa abordagem para definir híbridos da seguinte forma:

Arranjos híbridos estabelecem uma estrutura de governança voltada à resolução de um problema fundamental advindo da interação entre firmas: como economizar nos custos de contratação necessários a assegurar um comportamento não oportunista entre os parceiros do arranjo! ${ }^{19}$

\subsubsection{Alocação de pay-offs}

O segundo desafio apontado por Ménard como problemática fundamental dos agentes que optam por arranjos híbridos é encontrar uma maneira eficiente de distribuir a renda gerada pelo grupo. Alchian e Demsetz (1972) discutem essa problemática mostrando que atribuir a parcela correta da renda a cada participante de uma ação conjunta é muito difícil, porque a contribuição exata de cada um para a completude de um trabalho não pode ser efetivamente observada na maioria dos casos. Para arranjos multilaterais, como os híbridos, cuja ação conjunta é o ponto de partida da atividade econômica, a escolha de uma estrutura de governança com mecanismos apropriados para lidar com o desafio da distribuição eficiente da renda é fundamental.

\footnotetext{
${ }^{18}$ Nas palavras do autor: "two or more partners pool strategic decision rights as well as some property rights, while simultaneously keeping distinct ownership over key assets" (MÉNARD, 2010, p. 2).

${ }^{19}$ Nas palavras do autor: "[hybrids] define a mode of governance oriented towards solving the fundamental problem of interfirm networks: how to economize on contracting costs necessary to insure nonopportunistic behavior among autonomous partners" (MÉNARD, 2004, p. 363).
} 


\subsection{Direitos de propriedade}

Ao examinarmos a definição de formas híbridas, vimos que Ménard usa elementos da Teoria de Direitos de Propriedade para discutir suas características. Uma breve revisão dos conceitos envolvidos nessa teoria será apresentada a seguir.

De acordo com Cooter e Ulen (1988), direitos de propriedade são conceituados como o conjunto de direitos sobre um recurso que seu proprietário está livre para exercer, e cujo exercício é protegido contra a interferência de outros agentes. Alchian (1987, p. 1031) define direito de propriedade como: “o direito de usar, transformar e se apropriar da renda gerada por determinado ativo ${ }^{20}$.

A relação básica entre o conceito de direito de propriedade e a economia vem a partir do reconhecimento de que a transação é uma troca de direitos de propriedade. Essa relação foi inicialmente indicada por Demsetz (1967). Para tanto, o autor retoma o conceito de que a imperfeição na definição de direitos de propriedade é capaz de gerar externalidades, positivas ou negativas. Sendo assim, o autor sugere que, enquanto os custos de internalizar as externalidades forem menores que os ganhos de fazê-lo, os agentes deste modo o farão, promovendo a definição dos direitos de propriedade, num processo de busca por eficiência.

Alchian e Demsetz (1972) utilizam o conceito de definição de direitos de propriedade para fazer uma contribuição importante na análise econômica do processo produtivo. Os autores mostram que existem situações em que é muito difícil atribuir a parcela correta da contribuição de cada agente envolvido em uma atividade conjunta. Em outras palavras, quando os direitos de propriedade estão mal definidos, não se sabe ao certo qual é a contribuição exata de cada participante para atingir o objetivo final numa atividade em grupo. Os autores também mostram que além dessa dificuldade intrínseca, surge uma preocupação típica ao se tentar fazer a divisão do resíduo nessas circunstâncias: a preocupação com o possível comportamento oportunista dos agentes, que podem querer se aproveitar de uma situação de incerteza (gerada pela baixa definição dos direitos de propriedade) para tentar expropriar renda de seus parceiros.

\footnotetext{
${ }^{20}$ Nas palavras do autor: "the right to use assets, to change their form or substance, and to appropriate returns" (ALCHIAN, 1987, p. 1031).
} 
Logo, pode-se apontar a ligação entre a Teoria de Direitos de Propriedade e a Abordagem de Governança da ECT. Essa ligação também está baseada na definição, ou não, dos direitos de propriedade. Assim, quanto mais definidos forem os direitos de propriedade trocados numa transação, menores as externalidades negativas geradas e menores serão os custos de transação $^{21}$, o que influencia diretamente o processo de escolha da estrutura de governança, conforme vimos nas explicações de Williamson (1991).

\subsection{North e a influência do ambiente institucional}

Até agora foram discutidos vários pontos da NEI ligados ao nível micro de análise da interação entre os agentes, pois dado que a ECT discute a racionalidade econômica da transação a partir dos seus atributos, assumindo o ambiente institucional como dado. Os tópicos abordados a seguir complementam a ECT devido à sua abordagem macro, preocupando-se com a influência de elementos exógenos à transação sobre a interação dos agentes econômicos.

Douglas North é o principal autor da linha de análise macro (ou macroinstitucional, como classifica Williamson (1996)). North $(1990 ; 1994)$ tem seu trabalho voltado à influência do ambiente institucional sobre a interação dos agentes. Ele aponta o ambiente como um dos determinantes das oportunidades e ameaças que surgem frente às organizações e mostra como o ambiente (as instituições) influência a eficiência econômica.

\subsubsection{Instituições e organizações}

De acordo com North (1990), instituições são 'as regras do jogo', ou seja, as regras que orientam a interação entre as pessoas, e, consequentemente, orientam a interação entre os agentes econômicos. As instituições podem ser formais ou informais, sendo que, as indicadas pelo Estado são denominadas formais, e aquelas frutos de outras convenções são

\footnotetext{
${ }^{21}$ Foss e Foss (2005) oferecem uma discussão complementar a esta, ao apontar a influência da definição dos direitos de propriedade sobre a alocação eficiente de recursos nas transações.
} 
denominadas informais. Instituições informais são formadas por regras, padrões individuais, costumes e outras convenções compreendidas na cultura de uma população. North (1990; 1994) considera ambos os tipos como relevantes para compor o ambiente institucional.

No que se refere às organizações, North $(1990 ; 1994)$ define que estas surgem por meio da agregação de atores (indivíduos) com objetivos em comum. Portanto, firmas, clubes, partidos políticos, organizações de classe, são alguns exemplos de organizações, sendo que essas podem ser públicas ou privadas. Enquanto North define o ambiente institucional como as 'regras do jogo', as organizações ficam definidas como os participantes desse jogo, ou seja, os próprios jogadores. Entendendo o ambiente institucional dessa forma, percebe-se que ao definir as regras do jogo, definem-se também as oportunidades e ameaças que irão se apresentar frente às organizações. Desta forma, o ambiente institucional deve ser visto como um dos determinantes da escolha estratégica da firma.

\subsubsection{Instituições, direitos de propriedade e custos de transação}

O conceito de 'regra do jogo' deve ser compreendido não apenas pela parte da existência do regramento, mas também pelo mecanismo que garante seu cumprimento (NORTH, 1994). A tomada de decisão dos atores pode ser muito distinta à medida que eles sabem que podem ser punidos, ou não, pelo descumprimento de uma determinada regra. Neste sentido, as instituições, à medida que definem as regras do jogo (e seus mecanismos de garantir seu cumprimento), acabam definindo toda uma estrutura de incentivos e punições a que estarão sujeitos os agentes, o que também pode ser chamado de arcabouço institucional.

Para a NEI, a ligação entre a análise macroinstitucional e microinstitucional está na influência do ambiente institucional sobre a definição dos direitos de propriedade. Conforme explica North $(1990 ; 1994)$, o arcabouço institucional que envolve a relação entre os agentes é capaz de influenciar diretamente a definição dos direitos de propriedade transacionados. Esta influência pode ser verificada sob dois aspectos. O primeiro aspecto é a influencia na definição dos atributos dos direitos transacionados, podendo diminuir divergências de opinião sobre a transação, geradas pela limitação cognitiva dos agentes (Racionalidade Limitada). O segundo aspecto é a influência sobre a proteção desses direitos, visto que, conforme disposto 
no início dessa seção, o efeito da definição dos direitos de propriedade sobre a economia somente será verificado se houver segurança de que suas prerrogativas serão resguardadas (EGGERTSSON, 1990).

Evidencia-se, assim, a ligação entre análise macro e microinstitucional, a partir da capacidade de o ambiente influenciar a definição e proteção dos direitos de propriedade, o que determina a ocorrência dos custos de transação ${ }^{22}$ e, consequentemente, influencia a escolha eficiente de governança (conforme explica a ECT de Williamson).

\subsubsection{Instituições privadas}

Para terminar a revisão sobre ambiente institucional, será apresentado em mais detalhes o conceito de instituições privadas (private institutions), devido à importância dada por Ménard a este conceito para compor seus modelos de análise de formas híbridas.

Conforme Brousseau e Raynaud (2006), a compreensão das características das instituições privadas vem à tona quando o ambiente institucional é analisado sob uma ótica multinível. Brousseau e Raynaud (2006) compartilham das ideias de North (1990; 1994) quanto à influência do ambiente institucional sobre a coordenação das transações, e de que a chave para esse efeito está na definição e proteção dos direitos de propriedade. Eles propõem que o ambiente institucional, tratado uniformemente por North (1990; 1994), deveria ser dividido em dois subgrupos para análise. Tal divisão formaria o grupo das instituições privadas e o grupo das instituições genéricas.

Instituições genéricas são aquelas impostas aos agentes de forma mandatória, sem deixar opção de escolha e sem permitir negociações quanto ao seu conteúdo. Geralmente, tal conteúdo é pouco específico. Nesse grupo encontram-se as leis impostas pelo Estado e algumas convenções culturais não negociáveis, como por exemplo, a linguagem.

Instituições privadas são aquelas cuja adesão é voluntária e existe, sim, espaço para a negociação de seu conteúdo, o qual é bem mais específico que o das instituições genéricas.

\footnotetext{
${ }^{22}$ Conforme visto na seção 2.5 , sobre direitos de propriedade.
} 
Nesse grupo encaixam-se estruturas como, por exemplo, clubes, associações de classe e códigos de auto regulação. Cabe observar que tanto as instituições privadas como as genéricas são coletivas, influenciando um grupo de indivíduos ao mesmo tempo. As instituições genéricas são destinadas a grandes grupos, enquanto as privadas, geralmente, influenciam grupos menores.

Seguindo a classificação de Brousseau e Raynaud (2006), a coordenação das transações passaria a ser analisada a partir de três níveis, ou seja: as instituições genéricas, as instituições privadas e os arranjos institucionais (arranjos contratuais bilaterais). Os autores consideram que as instituições genéricas apontadas por eles remetem ao conceito de ambiente institucional proposto por North (1990), sendo assim, eles estariam incluindo o nível intermediário das instituições privadas na estrutura de análise, que, na proposta de North (1990), somente contava com o ambiente institucional e os arranjos contratuais bilaterais.

Para Brousseau e Raynaud (2006), o surgimento e a adoção das instituições privadas ocorrem quando a estrutura de coordenação oferecida pelas instituições genéricas somadas aos contratos bilaterais não são capazes de suprir as necessidades dos agentes ou são muito caras. O modelo proposto por Brousseau e Raynaud (2006) admite que os agentes irão usar os três níveis de coordenação da forma que maximize seus benefícios. Eles poderão, inclusive, compor o uso das três estruturas ao mesmo tempo, equilibrando as falhas de uma com as capacidades de outra, se isso lhes oferecer vantagem.

Como será visto mais a frente, no Modelo de Ménard (2010), as private institutions apontadas por Brousseau e Raynaud (2006) aparecem como um dos determinantes da escolha eficiente de governança. A seguir, serão discutidos os modelos de 2004 (capítulo 3) e 2010 (capítulo 4) de Ménard para análise de formas híbridas. 


\section{MÉNARD 2004 E AS FORMAS HÍBRIDAS}

Ménard (2004) desenvolve seu modelo baseando-se em dois determinantes básicos à escolha da forma organizacional que as firmas têm que fazer. Mantendo-se fiel à tradição neoinstitucionalista e à ECT de Williamson, Ménard (2004) parte do princípio de que são a incerteza e a especificidade dos ativos as principais variáveis capazes de influenciar o tipo de forma híbrida mais apropriada à interação de um conjunto de agentes. Conforme foi apontado até o momento, existe um grande paralelo da proposta de Ménard com a ECT. Deve-se atentar a uma diferença crucial: no modelo de Ménard (2004), a preocupação não é com a acomodação de uma única transação, mas com um conjunto delas.

\subsection{Investimento e interdependência}

Ao indicar a especificidade dos ativos como um dos determinantes da escolha híbrida, Ménard (2004) chama a atenção para uma característica de investimentos feitos para esta finalidade, que é a dependência entre as partes envolvidas na transação. A renda esperada do investimento depende da relação dos agentes (cooperação), pois a tomada de decisão sobre os ativos oriundos de tais investimentos é conjunta. Ménard $(2004 ; 2010)$ costuma usar o termo em inglês to pool resources para se referir à disposição (investimento) de participar de atividades conjuntas.

Ao optar por participar de um arranjo híbrido e deixar certa porção de sua propriedade a disposição do grupo (to pool resources), o agente econômico irá incorrer numa situação de dependência. Para Ménard (2004), é a intensidade dessa dependência o ponto mais importante a ser considerado. O autor sugere que, para governar relações de maior dependência, é necessário maiores mecanismos de controle ${ }^{23}$ e mais centralização ${ }^{24}$ visando à eficiência da forma organizacional escolhida.

\footnotetext{
${ }^{23}$ Nas palavras do autor: "the more specific mutual investments are, the higher are the risks of opportunistic behavior, and the tighter are the forms of control implemented" (MÉNARD, 2004, p. 354).

${ }^{24}$ Nas palavras do autor: "the greater is the appropriation concern, which grows with the specificity of investments, the more centralized the coordination tends to be" (MÉNARD, 2004, p. 357).
} 
A racionalidade subjacente às colocações feitas por Ménard (2004) é a mesma que está por trás do problema de hold-up. Em ambos os casos, a dependência torna os agentes susceptíveis ao comportamento oportunista de seus parceiros. Desta forma, é necessário criar mecanismos para proteger os investimentos do comportamento oportunista e, ao mesmo tempo, coibir esse tipo de comportamento no grupo. Para caracterizar os investimentos em relação à interdependência gerada, Ménard (2004) sugere que se deva classificá-los de acordo com a estratégia que está sendo usada pelos agentes: se é uma estratégia baseada em complementaridade ou se é uma estratégia baseada em investimento conjunto. Classificando dessa forma, pode-se esperar uma intensidade de interdependência mais forte em casos de investimentos conjuntos e mais branda em casos de simples complementaridade.

\subsection{Incerteza}

A incerteza é o segundo determinante apontado por Ménard (2004). Uma ressalva deve ser feita: o autor vê a incerteza como variável que depende da existência de investimento específico (interdependente) para produzir efeito sobre a escolha da forma organizacional final. Sobre as variáveis apontadas até agora, de acordo com a posição do autor, pode-se dizer que a interdependência dos investimentos poderia ser classificada como variável independente, a forma organizacional como variável dependente e a incerteza como variável moderadora $^{25}$. A Figura 2, apresentada a seguir, ilustra essa relação.

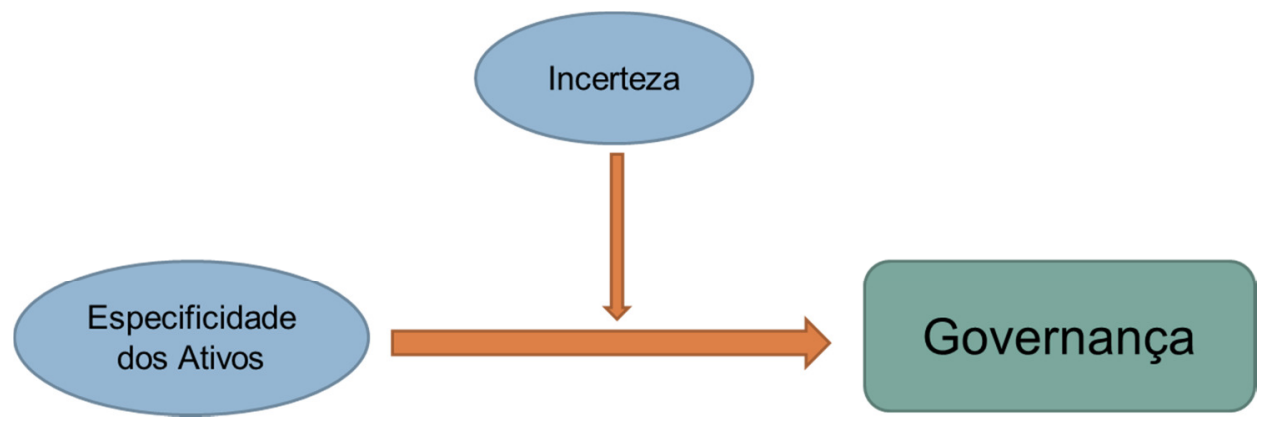

Figura 2 - Relação de variáveis no Modelo de 2004

Fonte: elaborado pelo autor, com base em Ménard (2004)

\footnotetext{
${ }^{25}$ Variável moderadora é aquela que influencia a ação de uma variável independente (MARCONI; LAKATOS, 2000, p. 197).
} 
Ménard (2004) explica que a incerteza pode gerar dificuldades processuais, influenciando o processo de adaptação da relação dos agentes no tempo, conforme explicado anteriormente ao definir-se o conceito de formas híbridas (Seção 2.3.2.1 - coordenação de atividades conjuntas) e ao serem explicitadas as bases da ECT (Seção 2.2.3).

Para Ménard (2004), um tipo específico de incerteza deve ser observada como mais atenção, a incerteza gerada por receio de comportamento oportunista de algum participante do arranjo devido a brechas, falhas e limitações dos contratos firmados. O autor refere-se a este tipo de incerteza por consequential uncertanty. A importância de se detectar a consequentional uncertanty está na sua íntima ligação com o comportamento oportunista dos agentes, pois, para Ménard (2004), que se mantém fiel à ECT de Willamson, quanto maior o risco de comportamento oportunista, mais centralizada deverá ser a forma de governança para acomodar as transações (para mais detalhes, ver Ménard, 2004, p. 358).

\subsection{O Modelo de 2004 e seus mecanismos de governança}

Ménard (2004) argumenta que três dimensões devem ser contempladas ao formar-se um mecanismo de governança: a capacidade de equalizar os riscos contratuais, de arbitrar adequadamente a divisão da renda gerada e a capacidade de garantir que as regras internas aos arranjos sejam cumpridas. Um dos mecanismos que pode contemplar todas as dimensões apontadas por Ménard (2004) é o mecanismo contratual. Mas, em determinadas situações, os contratos não conseguem, sozinhos, prover toda a coordenação necessária para que as transações ocorram. Para Ménard (2004), quando isso ocorre, outros mecanismos são necessários para complementar a composição da governança das transações em arranjos híbridos.

Antes de seguir para a discussão de cada dimensão e dos mecanismos apontados por Ménard (2004), deve-se esclarecer que o autor vê a governança híbrida como a somatória destes mecanismos, em que a presença de um não implica a exclusão de outro. Em seu modelo, os mecanismos completam-se, sendo que em determinadas situações um dos mecanismos é usado mais intensamente que os outros, podendo ser apontado como principal. 
Outro ponto importante para a compreensão do modelo de Ménard (2004) é de que o autor valoriza a característica relacional ${ }^{26}$ dos contratos e de seu uso como estrutura básica (framework) na negociação e formatação dos arranjos. A seguir serão discutidas com mais detalhes cada uma das três dimensões ${ }^{27}$ apontadas por Ménard como desafio a ser resolvido pelos mecanismos de governança.

\subsubsection{Equalização do risco contratual nas relações híbridas}

O contrato é o primeiro instrumento a ser indicado para reduzir riscos processuais na coordenação e diminuir a possibilidade de comportamento oportunista dos agentes. Contratos definem especificações técnicas sobre a qualidade e quantidade dos produtos transacionados, além de conectar os agentes num cronograma comum. Os contratos ajudam a selecionar os participantes do arranjo, diminuindo a possibilidade de participação de free riders ${ }^{28}$, além de indicarem o número máximo e mínimo de participantes do arranjo. A duração dos contratos influi no horizonte da relação dos agentes e abre espaço para consideração de selfenforcement $^{29}$.

Além dos contratos, Ménard (2004) indica o mecanismo de reputação como uma possibilidade de lidar com as dificuldades de adaptação e oportunismo. Para Ménard (2004), a reputação também influi na escolha dos integrantes dos arranjos e coíbe o oportunismo dos agentes no longo prazo devido a eventual perda de valor que um agente incorreria caso resolvesse se comportar como um free rider e fosse descoberto: ele teria sua reputação destruída.

\footnotetext{
${ }^{26}$ Conforme discutido em detalhes na seção 2.2.4.

27 A capacidade de equalizar os riscos contratuais, de arbitrar adequadamente a divisão da renda gerada e a capacidade de garantir que as regras internas aos arranjos sejam cumpridas.

${ }^{28}$ Free rider é um termo usado para se referir ao agente econômico que pratica ações oportunistas sobre um grupo de que participa, expropriando valor (BAUMOL, 1952).

${ }^{29}$ Conforme definido na seção 2.2.3.
} 


\subsubsection{Divisão da quase-renda}

Conforme discutido anteriormente ${ }^{30}$, a alocação de pay-offs é um dos grandes desafios dos arranjos híbridos. A dificuldade intrínseca de se observar a contribuição exata de cada participante do arranjo para o objetivo final da organização pode ser um grande problema.

Ménard (2004) explica que os contratos conseguem lidar bem com situações em que existe a possibilidade de observar-se a contribuição de cada agente sobre o resultado final produzido pelo grupo, mostrando-se alinhado à visão de Alchian e Demsetz (1972) apresentada na Seção 2.4. Um exemplo disso nas relações de franchising seria o uso de royalties ${ }^{31}$, neste exemplo uma porcentagem sobre o valor total vendido parece retratar de forma fiel o esforço do franqueado.

Em casos em que a observabilidade do esforço e contribuição dos agentes é baixa, Ménard (2004) sugere outros mecanismos para arbitrar a distribuição dos pay-offs. O primeiro deles é a própria reputação de cada agente. Neste caso, o valor da reputação irá minimizar a possibilidade de uma atitude oportunista diante da situação em que não se pode efetivamente medir o desempenho de cada um. Uma segunda possibilidade é a indicação de poder discricionário para que alguém decida a melhor forma de resolver a questão. Esse tipo de dinâmica pode ocorrer de duas formas. A primeira delas é a indicação de delegados por parte dos integrantes do arranjo para negociar a melhor solução entre si. Comitês e assembleias seriam bons exemplos disso. A segunda forma é a criação de uma entidade para decidir os rumos do investimento conjunto. Neste caso, a situação é a em que os participantes do arranjo cedem direitos a uma entidade formal que passa a ter o poder de decisão (autoridade) sobre os investimentos e os rumos da atividade conjunta do arranjo. Como exemplo, pode-se citar a formação de joint-ventures para gerir parcerias emtre empresas.

Ménard (2004) utiliza o termo private government para referir-se a estas instituições (ou mecanismos) com capacidade de coordenar a ação dos agentes, devido à autoridade que lhes é conferida. Por serem entidades provenientes do próprio arranjo (cujo poder de coerção não

\footnotetext{
${ }^{30} \mathrm{Na}$ seção 2.3.2.2.

${ }^{31}$ Detalhes sobre taxa de roylties serão vistos na Seção 6.1.
} 
provém do Estado), elas são classificadas como instituições privadas (private). Por terem autoridade, são capazes de exercer controle e governança, daí o termo private government. Ménard (2004) está alinhado à forma como Brousseau e Raynaud (2006) definem instituições privadas (private institutions); nesta visão, os mecanismos de governança indicados são endógenos ao arranjo e complementam a coordenação exercida pelos contratos, conforme visto anteriormente, na Seção 2.6.3.

\subsubsection{Salvaguardas (enforcement issues)}

A terceira dimensão apontada por Ménard (2004) é a capacidade de garantir o cumprimento do acordo firmado. Para tanto os mecanismos têm que ser capazes de monitorar as atividades e, quando necessário, punir os indivíduos que não respeitarem 'as regras internas do jogo'.

Contratos podem ter clausulas que salvaguardam o acordo, mas em alguns casos isso não é suficiente. Ménard (2004) explica que, em situações de grande interdependência entre os agentes e forte risco de oportunismo, é mais adequado contar com a ajuda de outras instituições de governança (private government) munidas de autoridade para disciplinar os integrantes dos arranjos.

Ménard (2004) apresenta quatro possibilidades de mecanismos capazes de promover enforcement além dos contratos. Dois deles atuam por meio de autoridade, e os outros dois por meio de poder de exclusão. Os que atuam por meio de autoridade são: as Instituições de Governança Formais (formal government), ou seja, entidades formais criadas pelos participantes do arranjo como no exemplo dado das joint-ventures; e a Liderança (leadership), em que uma dada empresa pode exercer influência sobre o grupo (como no caso de empresas líderes em cadeias de suprimento), estando munida de poder discricionário para tanto. Redes de Relacionamento (relational networks), ou seja, um conjunto de normas formais adotada por um grupo e a Reputação (denominada pelo autor como: Trust), são os mecanismos que atuam por meio de seu poder de exclusão para disciplinar os agentes. 


\subsection{O Modelo 2004}

Sendo assim, Ménard (2004) alinha os mecanismos de governança discutidos na última seção à especificidade dos ativos (e à interdependência, consequentemente). No modelo, devido à forma como a incerteza é abordada por Ménard (2004) como variável moderadora, ela deve ser vista como adjuvante da variável especificidade dos ativos. A Figura $3^{32}$, apresentada a seguir, ilustra o modelo.

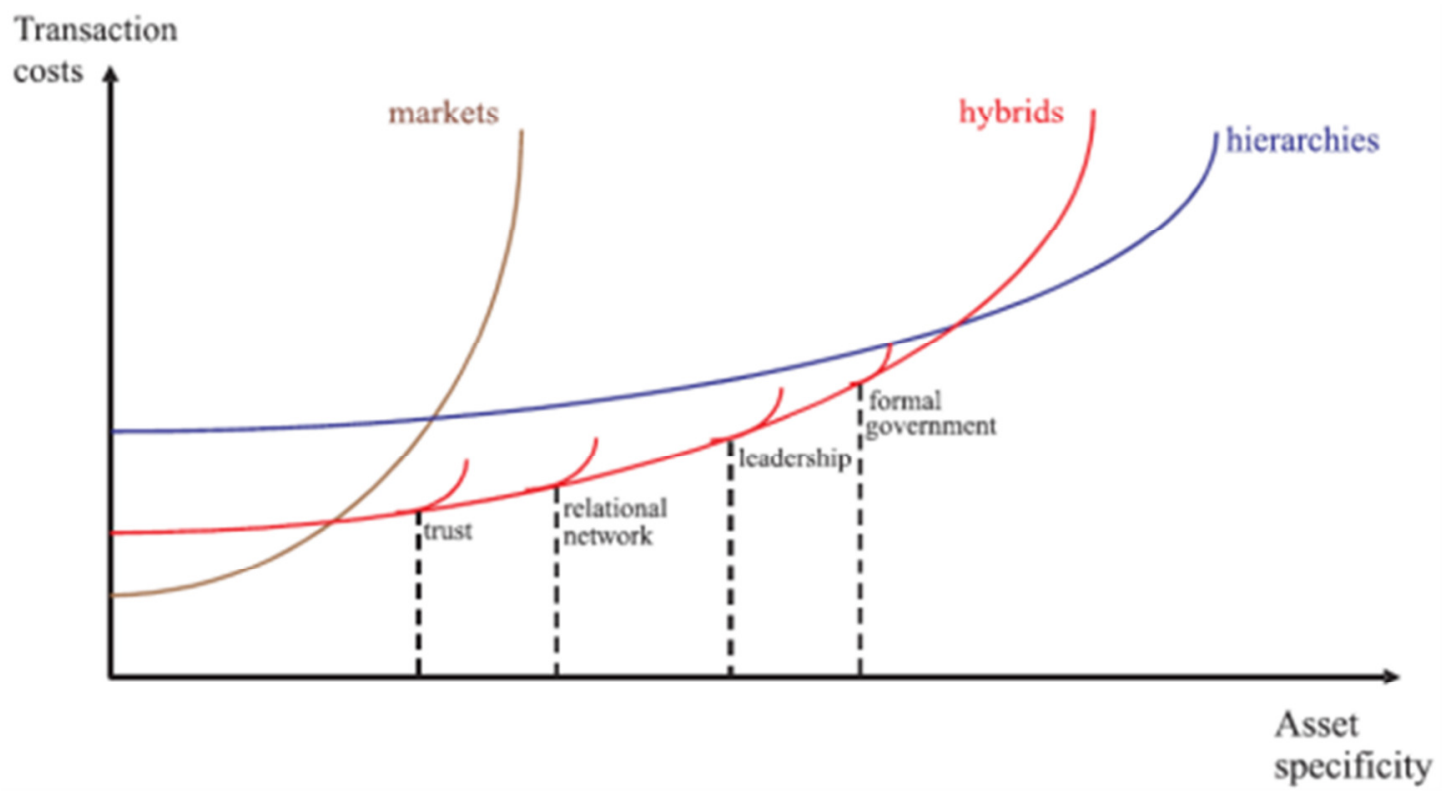

Figura 3 - Uma tipologia para Formas Híbridas Fonte: Ménard (2004, p. 369)

Observando o modelo, percebe-se que a formalidade dos mecanismos evolui com o aumento da interdependência. Na Figura 3, a formalidade evolui da esquerda para a direita, conforme aumenta a especificidade dos ativos. Exceto a Reputação, todos os mecanismos apresentados são formais. A centralização da decisão também pode ser observada no modelo. De acordo com Ménard (2004), a centralização irá aumentar juntamente com a intensidade da interdependência. Comparando os mecanismos do modelo em relação a esta característica, a proposta também parece consistente. Por último, vale apontar que a intensidade de autoridade compreendida por esses mecanismos também é distinta e aumenta no sentido da interdependência. Desta forma, instituições de governança formais serão aquelas a possuir o maior poder entre os mecanismos apresentados.

\footnotetext{
${ }^{32}$ Uma versão traduzida para o português da Figura 3, encontra-se disponível no Anexo III.
} 


\section{MÉNARD 2010 E AS FORMAS HÍBRIDAS}

No Capítulo 2, ao definir-se o conceito de formas híbridas, foi mencionado que Ménard (2004; 2010) as descreve como arranjos em que os participantes compartilham direitos sobre um conjunto de ativos. Também foi afirmado que um passo importante no desenvolvimento de seu trabalho foi a incorporação de elementos da Teoria de Direitos de Propriedade em sua modelagem.

A definição de formas híbridas para Ménard (2004; 2010) gira em torno do envolvimento de agentes em atividades conjuntas. Conforme foi explicado anteriormente, os agentes dispõem de uma parte de seus ativos e os deixam à disposição da iniciativa conjunta. $\mathrm{O}$ termo adotado por Ménard para se referir a este processo de investimento é [to] pool resources.

Ménard (2010) propõe um modelo para comparar a alocação dos direitos de propriedade em que duas firmas, envolvidas em atividades conjuntas, transacionam sob a égide das três estruturas de governança básicas: mercado, formas híbridas e hierarquia, podendo fazer uso de um centro estratégico como mecanismo de governança auxiliar na transação.

A Figura $4^{33}$, apresentada a seguir, ilustra a discussão apresentada por Ménard (2010).

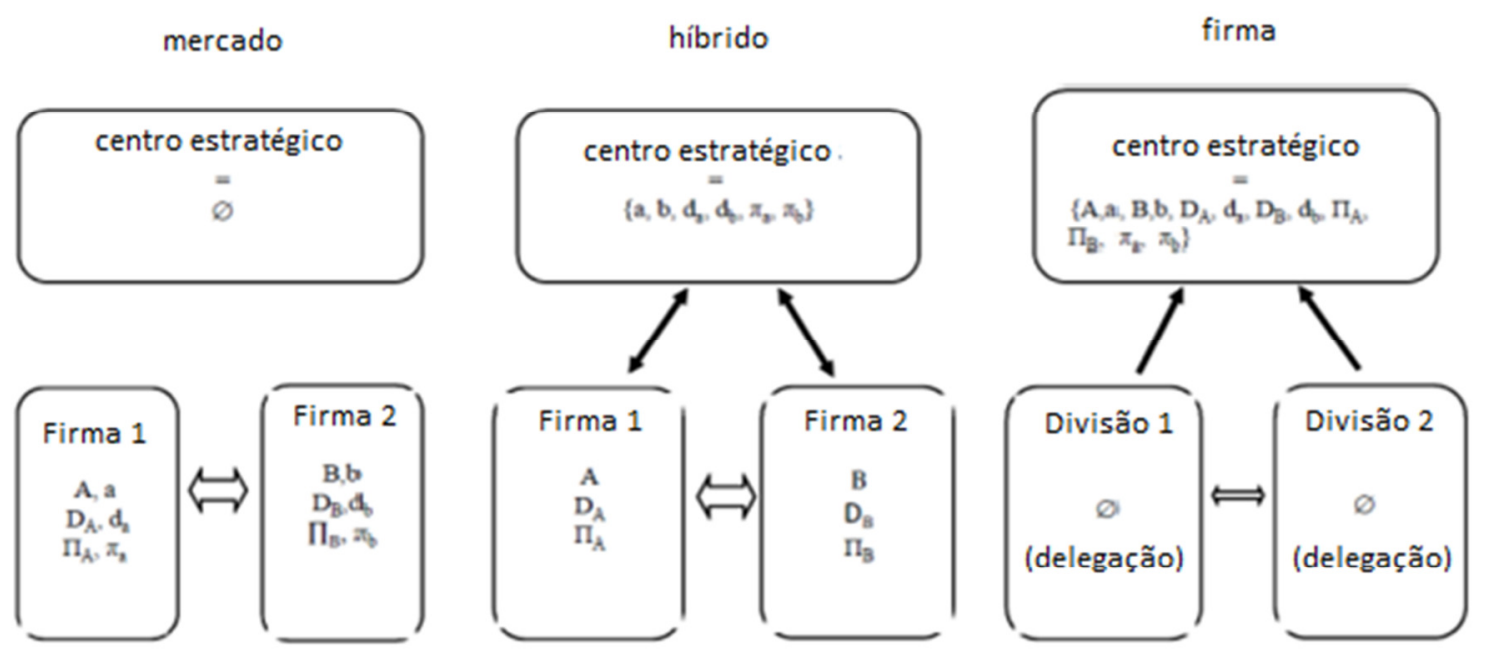

Figura 4 - Contrastando Formas de Organização

Fonte: Ménard, 2010, p. 15 (traduzido para a Língua Portuguesa pelo autor)

${ }^{33}$ A versão original em inglês da Figura 4 está disponível no Anexo III. 
Neste modelo, duas firmas: Firma 1 (F1) e Firma 2 (F2) transacionam. F1 detém os ativos:\{A e a e F2 detém os ativos: $\{\mathrm{B}$ e b $\}$. Os ativos: $\{\mathrm{a}$ e b $\}$ têm seu desempenho dependente à relação entre as duas firmas. As rendas geradas pelos ativos são: $\{\mathrm{PA}, \mathrm{pa}, \mathrm{PB}$ e pb\}. Os direitos de decisão sobre os ativos são: $\{\mathrm{DA}, \mathrm{da}, \mathrm{DB}$ e db\}. Os direitos de decisão: $\{$ da e db $\}$ dependem de coordenação, devido à característica de interdependência dos ativos que representam.

De acordo com o modelo, três padrões distintos de alocação de direitos de propriedade ocorrem à medida que variam as estruturas básicas de governança. Sob a égide do mercado, o centro estratégico não participa da transação. Na hierarquia, o centro estratégico detém todos os direitos e ativos, pois ele passa a fazer parte da firma. Quando a transação ocorre utilizando-se de uma forma híbrida, o centro estratégico detém apenas os direitos relacionados aos investimentos interdependentes.

Para Ménard (2010), havendo investimento interdependente, a alocação híbrida é a mais eficiente. De acordo com o aporte teórico usado pelo autor, é esta a alocação que minimiza a ocorrência de custos de transação.

\subsection{Determinantes da opção híbrida}

Em relação ao Modelo de 2004, o novo modelo não diverge quanto aos seus determinantes. A incerteza e a interdependência dos investimentos continuam sendo as variáveis apontadas como determinantes da opção híbrida. Como no trabalho de 2004, Ménard continua afirmando que o tipo de incerteza influencia a decisão tomada. Agora, ele já não utiliza mais o conceito de consequencial uncertainty, mas deixa claro que a incerteza causada pela possibilidade de comportamento oportunista é muito importante para o estudo em questão. Ademais, o investimento conjunto, como no modelo de 2004, continua sendo o centro do modelo e o responsável pela interdependência, sendo que a evolução na modelagem fica por conta da operacionalização destes investimentos usando parâmetros da Teoria dos Direitos de Propriedade. 


\subsection{Mecanismos de governança}

Ménard aponta quarto mecanismos de governança básicos para compor seu Modelo de 2010: os contratos relacionais, os centros estratégicos, as entidades exógenas e as redes de informação.

\subsubsection{Contratos relacionais}

O único mecanismo de governança presente no modelo de 2010 que persistiu desde o modelo 2004 é o dos contratos relacionais. A importância desse instrumento mantém a mesma racionalidade do que já foi apresentado durante a explicação do Modelo 2004, em que, em acordos repletos de elementos não contratáveis (non-contractabilitys), o contrato básico, um framework, funciona como guia para o relacionamento entre os agentes ao longo do tempo, ou seja, para que ajustes extracontratuais possam ocorrer.

Ménard (2010) vê o contrato relacional como uma ferramenta que aceita a complementaridade de outros mecanismos de governança para compor a coordenação mais adequada às transações no arranjo híbrido. Este atributo dos contratos relacionais é muito valorizado por ele.

\subsubsection{Centros estratégicos}

Entidades formais, endógenas ao arranjo, podem ser formadas para ajudar a coordenar as transações. Para que uma entidade dessas possa ser tomada por centro estratégico é necessário que os agentes deleguem direitos de propriedade a ela sobre os investimentos e atividades conjuntas do grupo. Para atuar como centro estratégico a instituição formada (private institution) deve ter autoridade sobre a atividade do grupo.

Não é necessário que o centro estratégico seja uma entidade especialmente criada pelos 
integrantes do arranjo. Uma das empresas do grupo pode ter a função de centro estratégico à medida que assuma uma posição de autoridade frente às outras integrantes. Esse ponto permite um paralelo com o Modelo de 2004, mostrando a evolução dos mecanismos de Leadership e Formal Government.

\subsubsection{Entidades exógenas (third parties)}

O centro estratégico tem como característica básica ser endógeno ao arranjo, e surge à medida que os agentes delegam autoridade a esta entidade. Ménard (2010) observa outro grupo de entidades capazes de influenciar a coordenação das formas híbridas, que não fazem parte do arranjo e que obtém sua autoridade do poder público: as Third Parties, que podem ser consideradas como entidades exógenas. Fazendo um paralelo com as definições de Brousseau e Raynaud ${ }^{34}$ (2006), as third parties de Ménard (2010) são uma fração das entidades genéricas apontadas pelos autores, que equivalem à definição de ambiente institucional de North (1990).

Ménard (2010) observa que estes mecanismos de coordenação são importantes quando a influência do ambiente institucional na relação dos agentes é relevante. Entidades exógenas podem ser públicas, como no caso de agências reguladoras (como a ANP, Agência Nacional do Petróleo, para o mercado de combustíveis), ou privadas, como no caso de empresas certificadoras.

O conceito de entidade exógena também permite pensar em entidades informais desempenhando as funções de mecanismo de governança. Em situações em que o poder de exclusão de uma instituição informal é suficiente para complementar a coordenação dos agentes, isso poderá ocorrer. Essa afirmação permite um paralelo do mecanismo de entidades exógenas com o mecanismo de trust, baseado em reputação, no Modelo de 2004.

${ }^{34}$ Discutidas na Seção 2.6.3. 


\subsubsection{Redes de informação}

O último mecanismo apontado por Ménard (2010) está ligado às dificuldades geradas pela assimetria de informação sobre o relacionamento dos agentes.

Se fosse possível diminuir tal assimetria, muitas relações e transações seriam facilitadas. O mecanismo se refere a redes ou sistemas de informações que facilitam a eleição de standarts de qualidade, a participação de vários agentes em cronogramas comuns, a troca de informação com rapidez e exatidão e até o compartilhamento de informações e conhecimento.

Redes de Informação também podem ser formais e informais. Entre os mecanismos apresentados por Ménard (2010), as redes de informação seriam os mais descentralizados em relação a sua capacidade de exercer autoridade e controle.

\subsection{Tipificando as formas híbridas}

Ménard (2010) conclui sua modelagem estabelecendo relações entre os mecanismos em si e, principalmente, entre os mecanismos e a alocação de direitos de propriedade.

Sobre a interação entre os mecanismos, o autor toma duas posições. Na primeira delas, ele admite que todas as formas híbridas são influenciadas por contratos relacionais, sendo esse um mecanismo que permeia qualquer arranjo híbrido. A segunda posição é enxergar a possibilidade de multiplicidade na ocorrência dos outros mecanismos, sendo que um é sempre mais relevante e acaba por tipificar o arranjo. Estas duas posições também são observadas no Modelo de 2004.

Para compreender a relação da alocação dos direitos e a opção por diferentes mecanismos de coordenação, ou seja, a racionalidade por trás da diversidade das formas híbridas, vale observar o modelo apresentado pelo autor, esquematizado a seguir na Figura $5^{35}$.

\footnotetext{
${ }^{35}$ Uma versão traduzida para o portugues da Figura 5 encontra-se disponível no Apêndice III.
} 


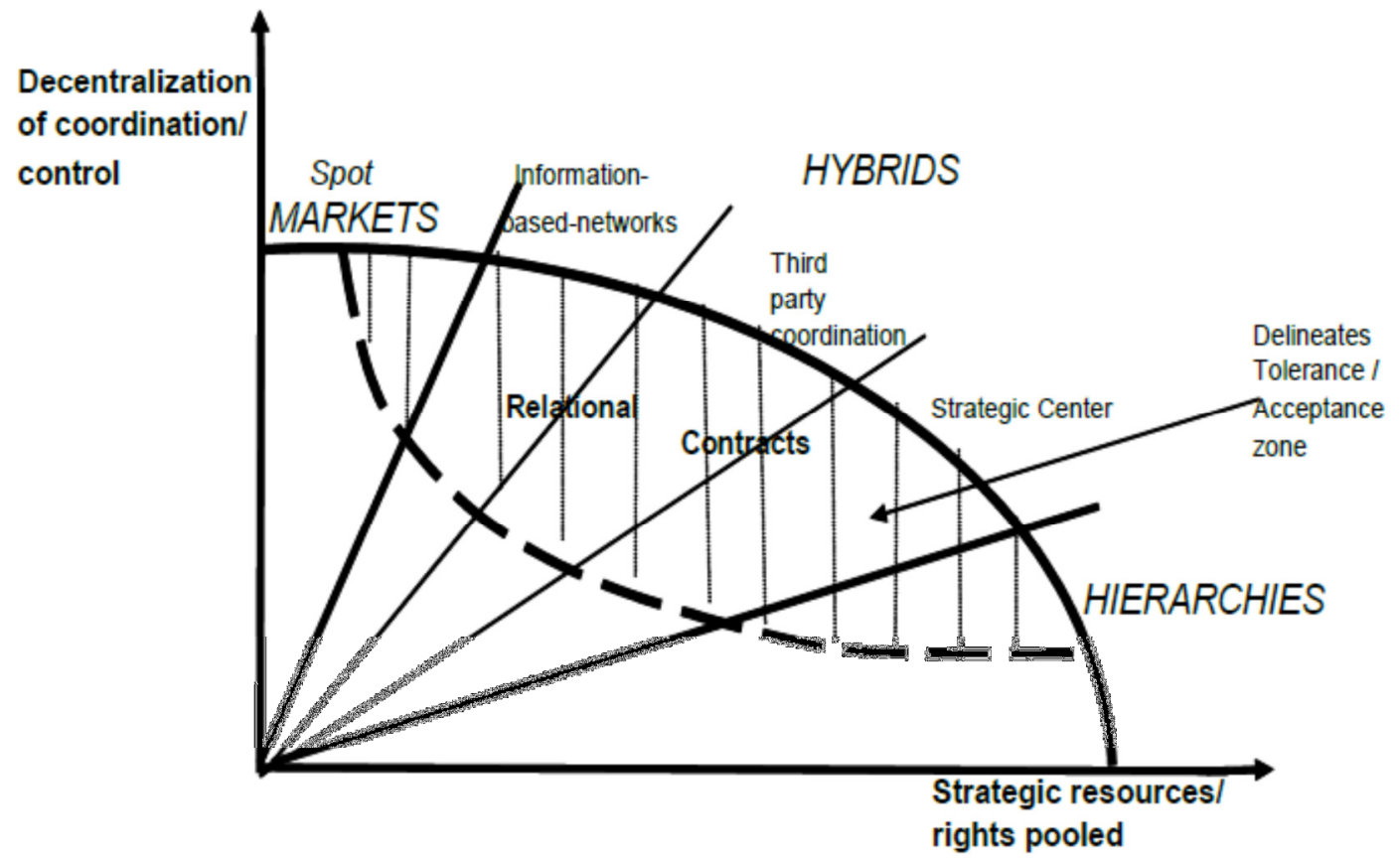

Figura 5 - Tipologia de Formas Híbridas (2010) Fonte: Ménard (2010, p. 50)

O modelo descreve duas variáveis determinando o arranjo híbrido. As variáveis são: 1) a dispersão dos direitos de propriedade e 2) a descentralização da coordenação.

O termo Strategic resources/rights pooled, constante do eixo das ordenadas, refere-se à forma como os direitos de propriedade sobre os investimentos foram alocados entre os agentes, conforme explicado no início do capítulo, ao discutir a Figura 4.

De acordo com o modelo descrito na Figura 5, quanto mais densa for a parcela de direitos de propriedade sobre os investimentos voltada à atividade coletiva, maior a necessidade da utilização de entidades específicas de coordenação (mecanismos de coordenação), sendo maior a tendência da utilização de centros estratégicos. No modelo, a opção mais adequada após o centro estratégico seria a de entidades exógenas e por último a de rede de informações (porque cada mecanismo tem uma capacidade intrínseca para o exercício de controle). Notase que o termo 'densidade“ foi usado propositadamente, como faz o próprio Ménard (2010, p. 14), para designar características de volume e relevância dos direitos.

A segunda variável apontada por Ménard, decentralization of coordination/control, também é um constructo que envolve mais de uma dimensão. O autor inclui ai, tanto a intensidade (tightness) como a centralidade da coordenação (MÉNARD, 2010, p. 14). Desta forma, em situações em que pouca centralização é suficiente para coordenar as transações, a opção por redes de informação seria a mais eficiente, seguida por entidades exógenas e, por último, viria a opção por centros estratégicos. 


\subsection{Relacionando as variáveis do Modelo}

Ao apresentar sua sugestão de tipificação de formas híbridas, Ménard (2010) aponta a relação das variáveis: dispersão dos direitos de propriedade e descentralização da coordenação, como determinantes da forma de governança eficiente.

É importante deixar claro que os determinantes desse processo continuam sendo a especificidade dos ativos (interdependência do investimento) e a incerteza, conforme colocado anteriormente e conforme sugere seu modelo anterior, de 2004.

Para se ter um entendimento mais completo da proposta de Ménard, as variáveis apresentadas na tipologia (dispersão dos direitos de propriedade e descentralização da coordenação) devem ser vistas como variáveis mediadoras ${ }^{36}$, a especificidade dos ativos (interdependência dos investimentos) como variável independente e a incerteza como variável moderadora ${ }^{37}$ do Modelo.

A Figura 6, apresentada a seguir, ilustra essa colocação. Conforme deixa claro o próprio autor (MÉNARD, 2010), a racionalidade por trás da interação das variáveis de seus modelos (2004 e 2010) é a mesma sugerida pela ECT de Williamson, cujo papel de destaque é a especificidade dos ativos.

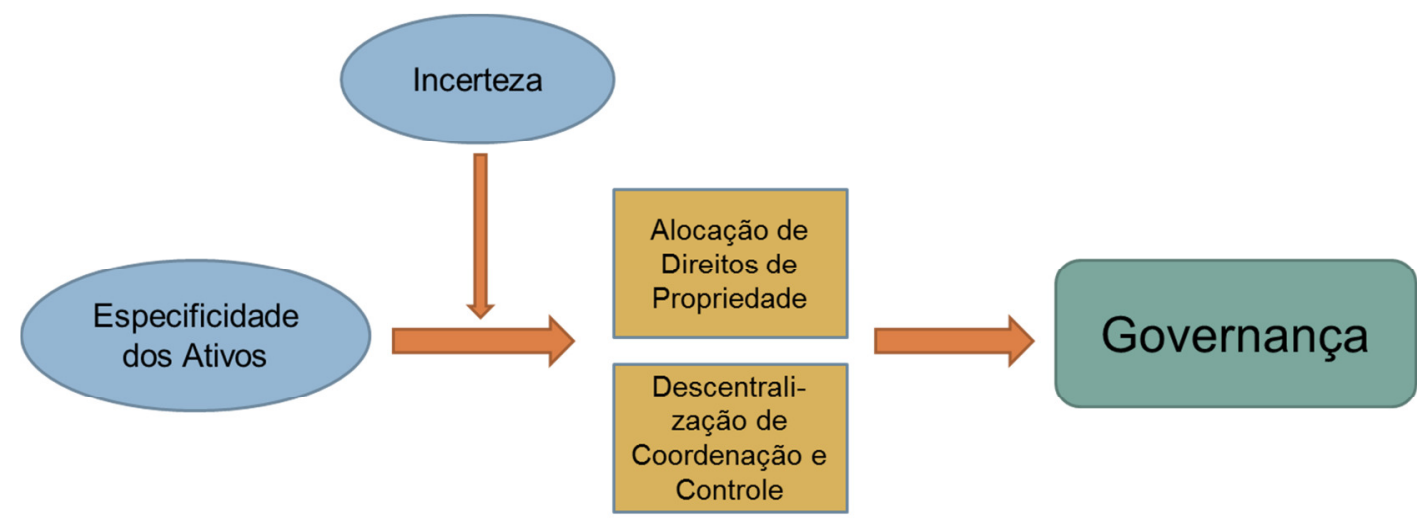

Figura 6 - Relação de variáveis no Modelo de 2010

Fonte: Elaborado pelo autor

\footnotetext{
${ }^{36}$ Variáveis mediadoras, ou intervenientes, intermediam a influência da variável independente sobre a variável dependente (MARCONI; LAKATOS, 2000, p. 211).

${ }^{37}$ Variável moderadora é aquela que influencia a ação de uma variável independente (MARCONI; LAKATOS, 2000, p. 197).
} 


\subsection{Ilustrando o Modelo de Ménard (2010)}

A ilustração apresentada a seguir foca o processo de dispersão de direitos de propriedade descrito no modelo de Ménard (2010), a partir de um exemplo hipotético de quatro firmas que se envolvem numa iniciativa conjunta.

Na Figura 7, apresentada a seguir, observa-se um conjunto de quatro firmas independentes (F1; F2; F3 e F4), as quais detêm ativos do tipo estrela e bolinha. Cada firma tem o conjunto completo de direitos de propriedade sobre seus ativos, representados pelas flechas duplas direcionadas de seus núcleos de comando em direção a seus ativos. No caso da Firma 1, o núcleo de comando seria a esfera central amarela e seus ativos a estrela amarela e as bolinhas verdes (a1, a2 e a3).

O termo núcleo de comando está sendo usado como uma forma de representar o poder total da firma sobre os ativos (um centro decisório). Os quadrados azuis seriam os limites legais das firmas.
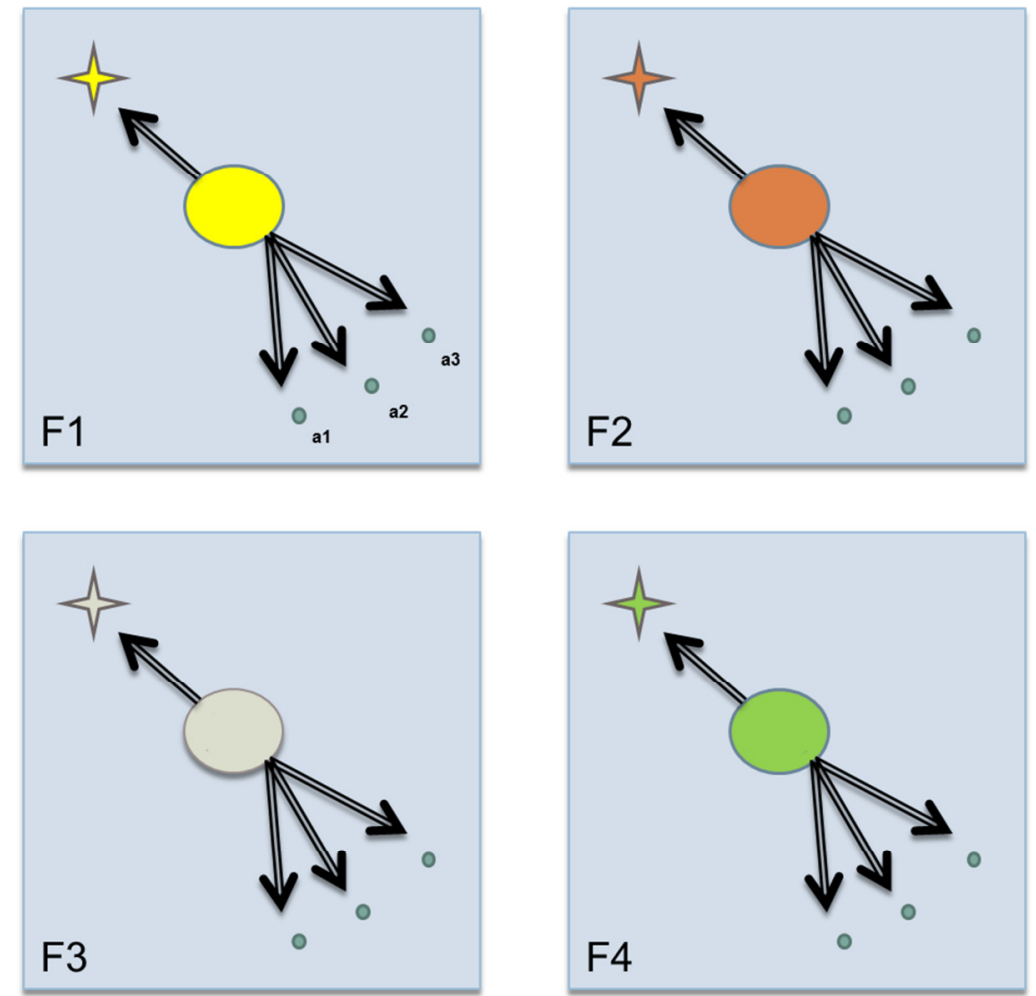

Figura 7 - Dipersão de Direitos de Propriedade (Pooling Resources) - Parte I Fonte: Elaborado pelo autor 
Na Figura 8, apresentada a seguir, observam-se firmas pooling resources, ou seja, elas passam a interagir e dispõem de ativos para a iniciativa conjunta. No exemplo, a Firma 1 coloca à disposição do grupo os ativos a1, a2 e a3. Nota-se que sua influência sobre sua estrela amarela continua intacta (flecha dupla), mas sua influência sobre as bolinhas verdes diminui (passando de flechas duplas para flechas simples). Nota-se também que o tamanho das bolinhas verdes aumenta (sendo agora denominadas: A1, A2 e A3), refletindo o aumento de seu valor quando têm a possibilidade de participar do grupo (devido à complementaridade entre estes ativos).

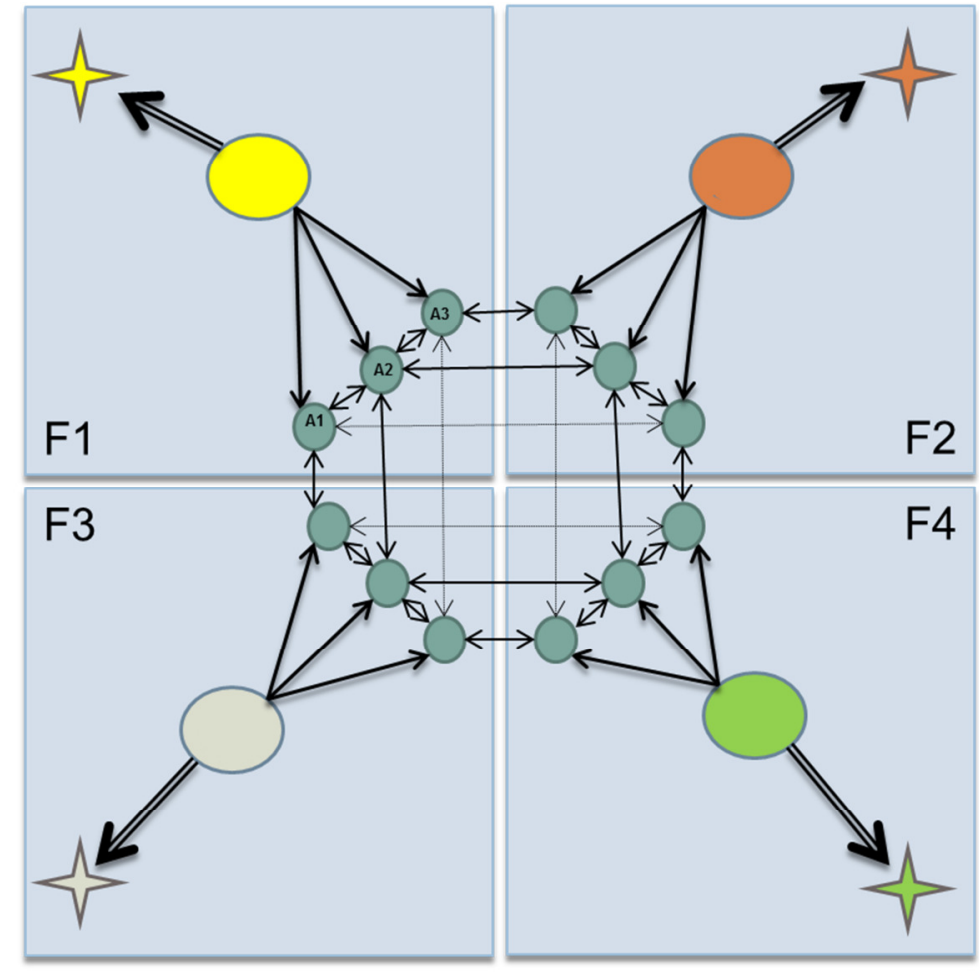

Figura 8 - Dispersão de Direitos de Propriedade (Pooling Resources) - Parte II Fonte: Elaborado pelo autor

Ainda na Figura 8, observam-se setas (flechas finas) interligando os ativos do pool, mostrando a interdependência entre estes ativos. Uma parcela dos direitos de propriedade originais foi transferida das firmas para o pool (processo de dispersão de direitos de propriedade). A partir desse momento, as decisões sobre o ativo A1, serão tomadas em função de F1 (flecha simples do núcleo de comando) e das outras três firmas (rede de influência do pool).

No exemplo sugerido pela Figura 8, poucos direitos de propriedade são transferidos ao pool. Nota-se que não ocorreu centralização do poder sobre os direitos adquiridos pelo pool. Assim, 
poderia-se classificar o exemplo como uma relational network, de acordo com o Modelo de Ménard (2010).

Na Figura 9, apresentada a seguir, uma quantidade maior de direitos de propriedade migra das firmas para a iniciativa conjunta (flechas simples dos núcleos de comando em direção às bolinhas verdes são substituídas por flechas simples mais finas). Neste exemplo, os direitos do pool começam a ser centralizados na Estrutura F5, um centro estratégico (de acordo com o Modelo de Ménard (2010)).

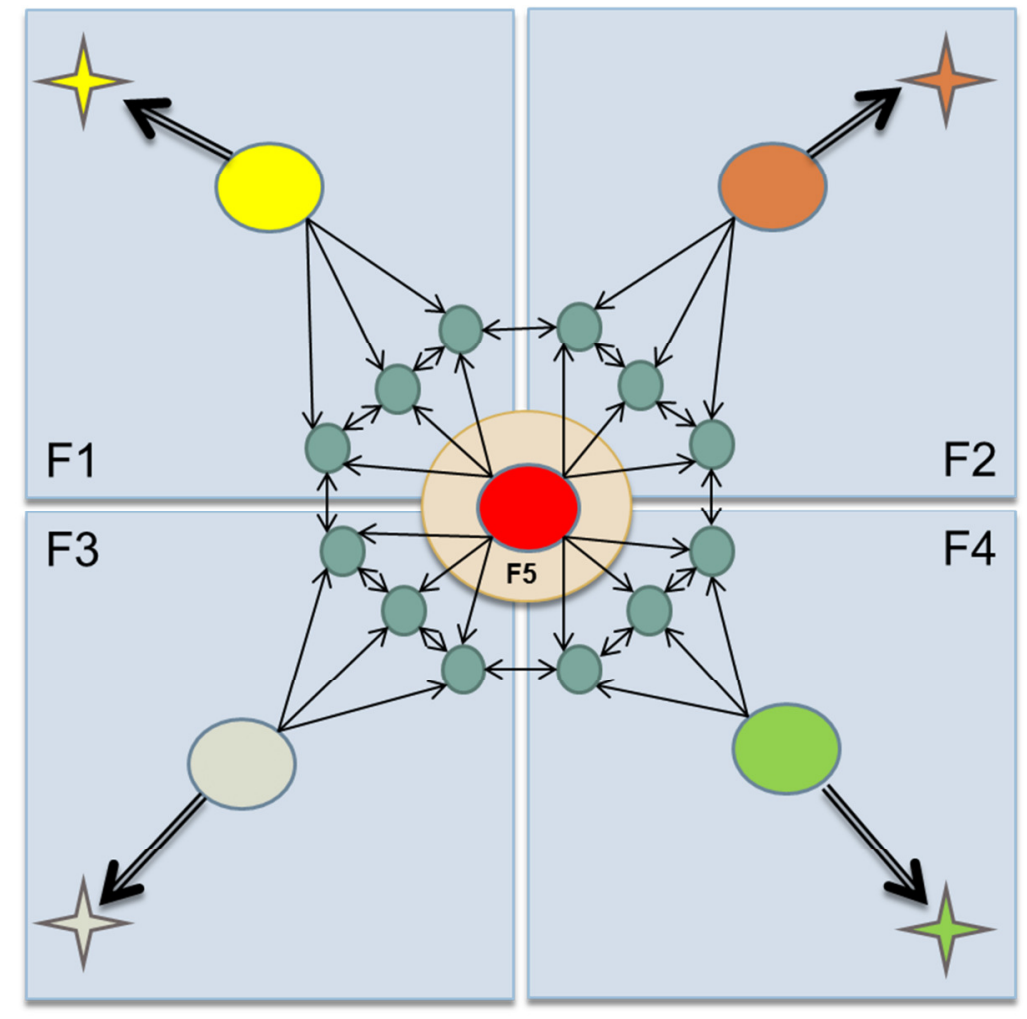

Figura 9 - Dispersão de Direitos de Propriedade (Pooling Resources) - Parte III Fonte: Elaborado pelo autor 
Na Figura 10, apresentada a seguir, mais direitos são cedidos ao pool. Estes direitos ficam centralizados no Centro Estratégico F5, que passa a atuar como uma nova firma, mantendo todos os ativos do tipo bolinha dentro de suas fronteiras legais. Essa nova configuração poderia ser entendida como um exemplo da formação de uma joint venture. A partir desse momento, as firmas já não influenciam diretamente os ativos cedidos inicialmente ao pool, mas têm influência sobre a Joint Venture.

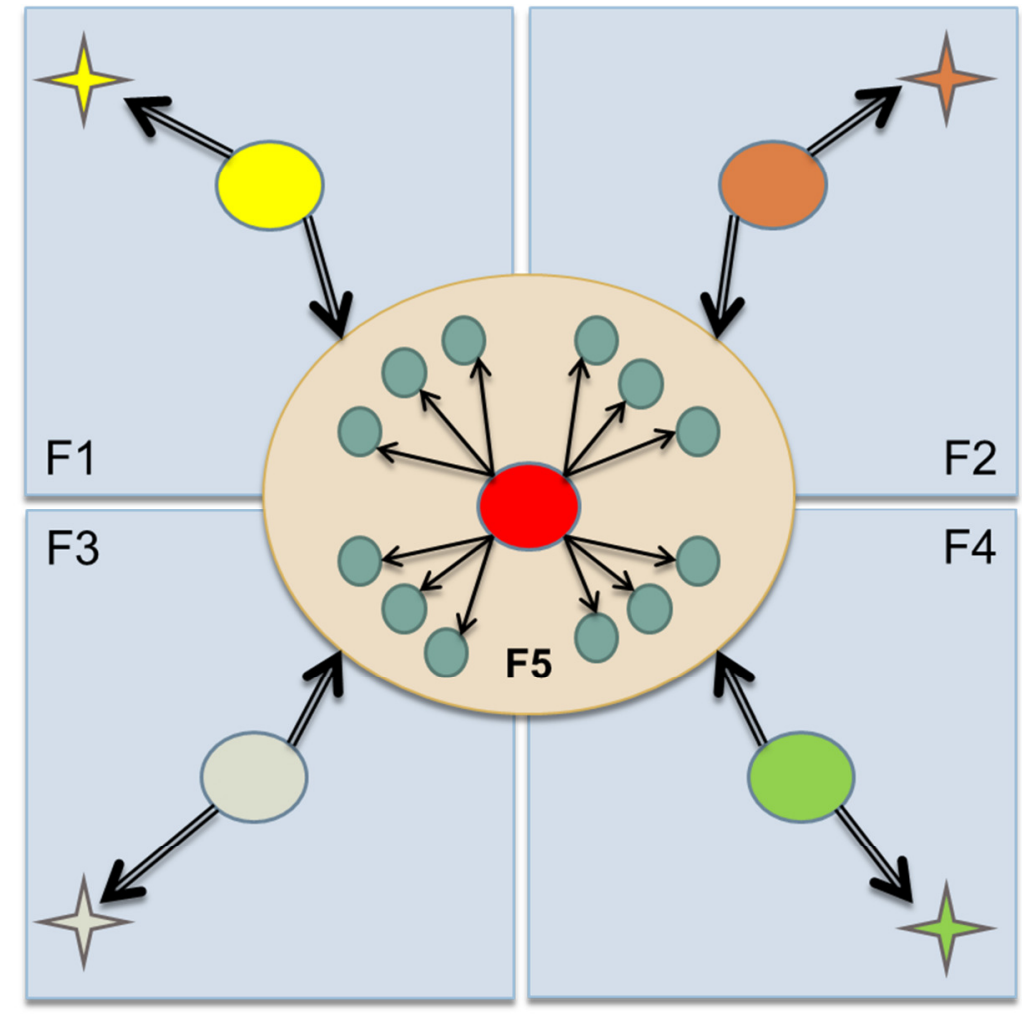

Figura 10 - Dispersão de Direitos de Propriedade (Pooling Resources) - Parte IV Fonte: Elaborado pelo autor

Terminada a apresentação da base teórica deste trabalho, a seguir, no Capítulo 5, será feita uma revisão específica sobre as características do setor de food service no Brasil. 


\section{O SETOR DE ALIMENTAÇÃO FORA DO LAR}

Para visualizar as atividades realizadas neste setor, assim como as empresas que o compõem, pode-se observar a cadeia produtiva alimentícia, desde a produção agrícola até o consumo final, conforme ilustra a Figura 11, apresentada a seguir.

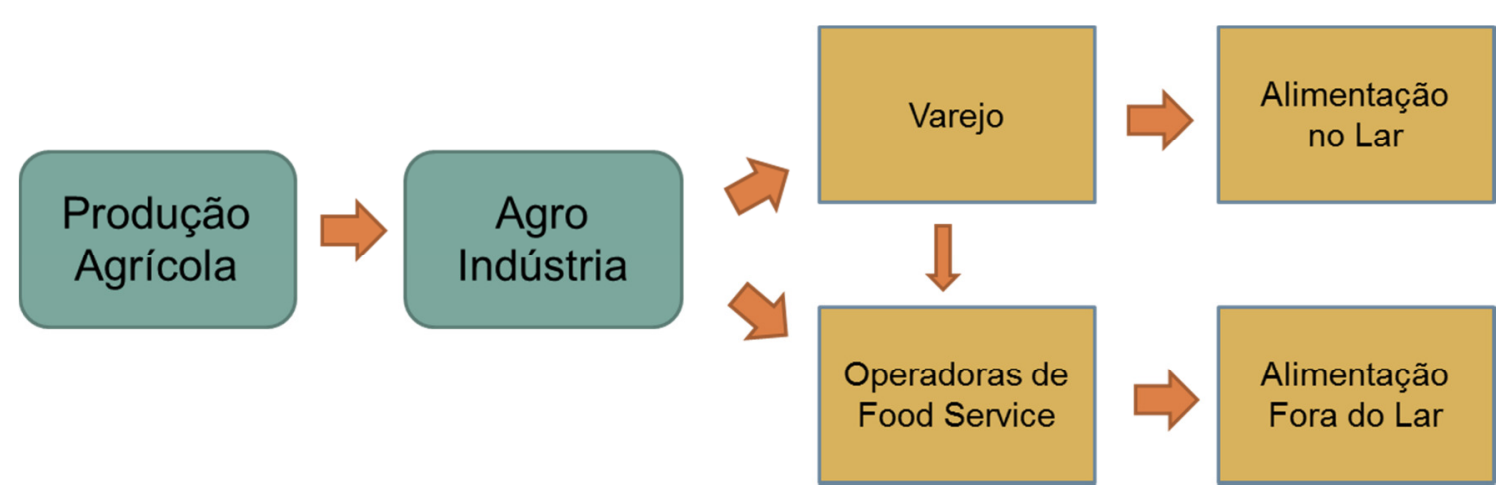

Figura 11 - A cadeia produtiva alimentícia Fonte: elaborado pelo autor

De acordo com esta figura, percebe-se a introdução do termo operadora de food service para designar o agente cuja atividade é oferecer o alimento para consumo fora do lar. O termo operadora está sendo usado aqui de acordo com a forma como é usado em inglês, pois no Brasil algumas pessoas usam este termo de maneira diferente. No Brasil, quando uma empresa de food service utiliza-se de uma estrutura organizacional baseada em franching ${ }^{38}$, algumas vezes o termo é usado para designar o franqueado, ou seja, exatamente o contrário da forma usada aqui. Neste trabalho, numa relação do tipo franchising, a operadora será sempre a franqueadora.

Observando em mais detalhes a relação da indústria de alimentos (na Figura 11, representada pelo termo Agroindústria) e as operadoras de food service, pode-se reconhecer os agentes que formam cada um desses blocos. A indústria de alimentos é responsável por suprir as operadoras com matérias primas básicas para a confecção de alimentos, como: açúcar, farináceos, laticínios e cárneos. Neste setor encontram-se empresas como, por exemplo: Sadia, Nestle, Unilever, Procter \& Gamble e Cargill. Outra componente deste bloco são as empresas de embalagens, como: Tetra Pack e Alpha Laval.

\footnotetext{
${ }^{38}$ Detalhes sobre essa forma organizacional serão dados no Capítulo 6.
} 
As operadoras de food service são os agentes que produzem os alimentos e oferecem condições para a alimentação fora do lar, assumindo a forma de: restaurantes, lanchonetes, bares, cafés, pubs, quiosques, padarias, praças de alimentação e outras mais.

A Euromonitor $(2011$; 2012) sugere que o primeiro filtro que se deve utilizar para compreender esse bloco tão heterogêneo das operadoras de food service é o tamanho de suas operações. Neste sentido, haveria apenas dois grupos: o agrupo das grandes empresas em formato de cadeia (chained) e as empresas pequenas com operações unitárias (também chamadas de stand alone).

Com relação à estratégia organizacional dessas cadeias, vale destacar que, de acordo com a Euromonitor $(2011 ; 2012)$, 90\% delas têm parte de suas operações sob contrato de franquia. Empresas como a argentina Arcos Dorados Holdings, a IMC (International Meal Company), a brasileira BFFC (Brasil Fast Food Corporation) e a mexicana ALSEA são exemplos de importantes holdings que operam cadeias no Brasil e no exterior. O Quadro 2, apresentado a seguir, dá mais detalhes da atuação dessas empresas apontando as marcas comercializadas por elas.

\begin{tabular}{|c|c|c|c|c|}
\hline EMPRESA & Arcos Dorados & $A L S E A S A B^{39}$ & $B F F C$ & $I M C$ \\
\hline $\begin{array}{l}\text { PRINCIPAIS } \\
\text { MARCAS }\end{array}$ & McDonald`s & $\begin{array}{l}\text { Domino's Pizza, } \\
\text { Starbucks, } \\
\text { Burger King, } \\
\text { Chili's, } \\
\text { California Pizza, } \\
\text { PF Chang`s }\end{array}$ & $\begin{array}{l}\text { Bob`s, } \\
\text { Pizza Hut, } \\
\text { KFC, } \\
\text { Doggis, } \\
\text { Yoggi }\end{array}$ & $\begin{array}{c}\text { Viena } \\
\text { Delicatessen, } \\
\text { Viena Express, } \\
\text { Brunella, } \\
\text { Frango Assado, } \\
\text { Carl`s Jr. }\end{array}$ \\
\hline
\end{tabular}

Quadro 2 - Principais operadoras de food service

Fonte: elaborado pelo autor, com dados de: Euromonitor (2011; 2012) e Lachini (2013)

A seguir, na Seção 5.1, será apresentada uma revisão sobre como o mercado de food service pode ser segmentado, evidenciando a importância do carácter de serviço nesta atividade, a partir de quatro exemplos de segmentação. Em seguida, na Seção 5.2, o caráter de serviço será visto em mais detalhes a partir da discussão do conceito de Experiência de Consumo. $\mathrm{O}$ capítulo finaliza com a Seção 5.3, que apresenta as principais influências do ambiente institucional sobre esta atividade.

\footnotetext{
${ }^{39}$ A ALSEA SAB é a operadora Domino`s Pizza e Starbucks no México. No Brasil a Domino`s Pizza é operada pela Umbria/Trigo e o Burger King é da 3G Capital Management.
} 


\subsection{A classificação das atividades do setor}

Os exemplos apresentados a seguir mostram que é possível classificar as operações de acordo com os segmentos de mercado atendidos. Essa segmentação é, geralmente, baseada no tipo (cusine) de alimento oferecido e nas características do serviço de atendimento (como: rapidez, estrutura física, local, conforto, disponibilidade de espaço, requinte do ambiente, equipe de atendimento etc).

A seguir serão apresentadas as classificações para os segmentos do mercado de food service da Euromónitor, do Anuário de Alimentação Fora do Lar, do USDA (United States Department of Agriculture) e da CHD Expert. Nota-se que todas levam em conta esses dois parâmetros principais: produto (food) e serviço (service) em suas propostas de classificação.

\subsubsection{A classificação das atividades do setor segunda a Euromonitor}

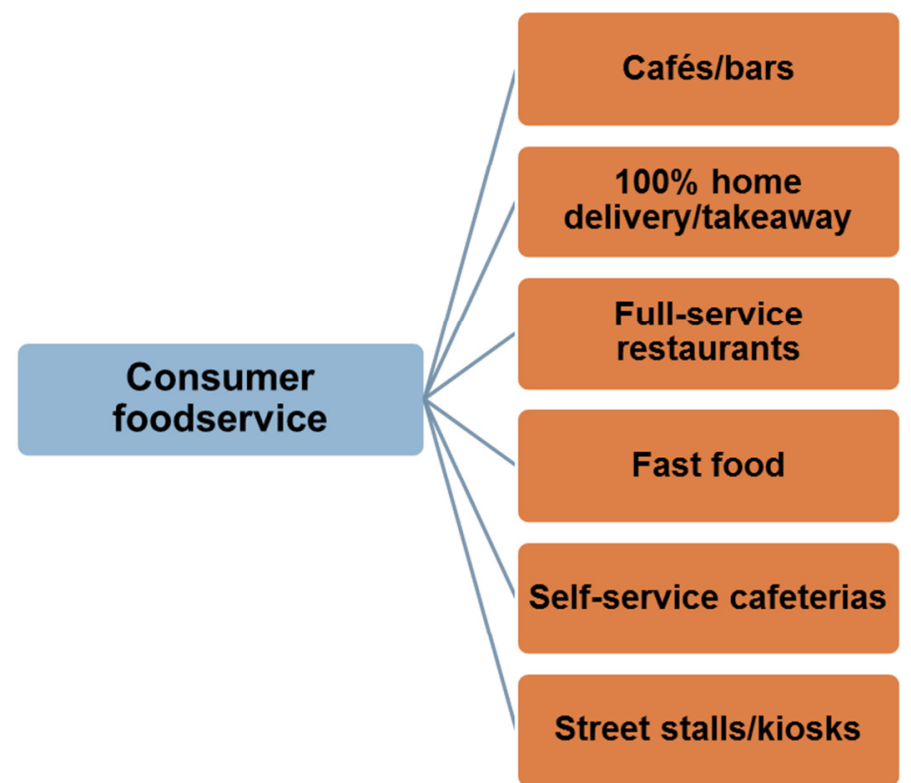

Figura 12 - Categorias (segmentos) em food service

Fonte: Euromonitor (2011, p. 3) 
A Figura $12^{40}$, apresentada anteriormente, aponta as seis principais categorias ${ }^{41}$ (segmentos) do food service, na visão da Euromonitor (2011; 2012). Na figura, são apresentadas as categorias comerciais (não ligadas ao governo, apontadas como: consumer food service)

Cafés/bars refere-se a estabelecimentos ligados ao consumo de bebidas. Esta categoria pode ser dividida em 4 subcategorias (ou product categories), a saber: a) bars/pubs, b) cafés, c) juice/smoothies ${ }^{42}$ bars e d) special coffee Shops. Para o mercado brasileiro a subcategoria de special coffee shops tem representantes importantes, como: A Casa do Pão de Queijo, o Café do Ponto, o Rei do Mate e a Starbucks. Os cafés, mais comuns na cultura europeia, são pouco representativos e os bars/pubs são volumosos e, geralmente, operados individualmente (stand alone).

A categoria de 100\% home delivery/takeaway está ligada a estabelecimentos que não oferecem acomodações para seus clientes consumirem seus produtos ${ }^{43}$. No Brasil, os maiores representantes desta categoria são as pizzarias delivery e em segundo lugar a culinária asiática. Nos EUA, os hambúrgueres e as pizzas detêm a maior participação do segmento, que também conta com uma expressiva participação de chicken (frango frito), bakery (massas e baked potato), mexican food e asian food.

A importância da comida asiática no segmento de takeaway é impar devido ao enorme volume de consumo de refeições neste formato em países asiáticos como China e Japão. Nestes países, os noodles são o principal produto do segmento.

A categoria de full service restaurants (FSR) envolve uma experiência de consumo completa, no local, oferecida pelo estabelecimento. Historicamente, a cozinha europeia tem sua relevância pela tradição (além do volume de negócios). O mercado americano é expressivo devido ao seu tamanho e pungência. Já o mercado asiático tem uma característica bastante peculiar, sendo esse tipo de hábito, o de consumir em restaurantes, muito importante e presente na cultura oriental. Pode-se afirmar que o consumo em full service restaurants é um

\footnotetext{
${ }^{40}$ Optou-se por não apresentar esta figura em português, pois todos os termos estão traduzidos no texto e serão utilizados no trabalho em inglês.

${ }^{41}$ A Euromonitor usa o termo categoria como sinônimo de segmento.

${ }^{42}$ Smoothies são bebidas geladas, geralmente frutadas, comuns nos EUA.

${ }^{43}$ Nota-se um conflito entre a nomenclatura da lingua inglesa e portuguesa. O consumo no caso do delivery ocorre na maioria das vezes no lar do consumidor, o que distoa da classificação de Alimentação Fora do Lar.... Apesar deste conflito, o delivery e o take away serão tratados neste trabalho como atividades integrantes do setor de food service.
} 
dos pilares das interações sociais na Ásia, sendo usado para celebrar casamentos, festas religiosas e todo tipo de confraternização. Devido ao tamanho e característica do consumo asiático, metade de todo o volume de refeições fora do lar do mundo são atribuídos ao consumo em full service restaurants, conforme ilustra o Gráfico $1^{44}$, apresentado a seguir.

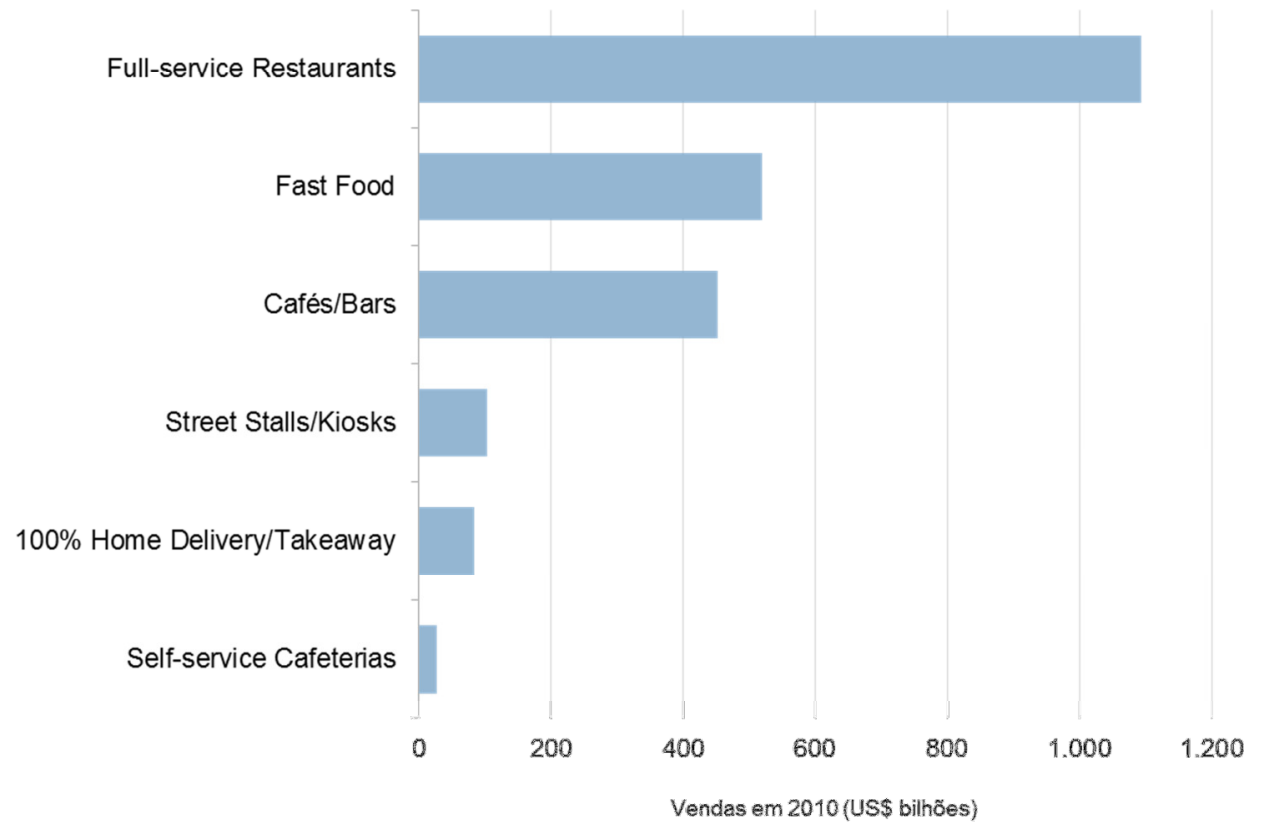

Gráfico 1 - Vendas por categoria no mundo Fonte: Euromonitor $(2011$, p. 8$)$

O fast food é a categoria mais forte entre as cadeias de food service. Seguido pelas self-service cafeterias e pelas $100 \%$ home delivery/takeaway, estas três categorias são os segmentos mais bem sucedidos das grandes empresas do setor (em contraste com o enorme número de FSR, stand alone, do mercado chinês).

A gama de produtos oferecidos via fast food é ampla. Entre seus product categries, pode-se citar: burgers, asian, bakery products, chicken, covenience store fast food, fast casual dining, latin american fast food, ice cream fast food, pizza e fish fast food. A influência da cultura americana neste segmento é forte e está ligada ao desenvolvimento deste arranjo ter sido fruto de sua cultura nacional, tendo como protagonistas o McDonald`s e o Burger King. Observando novamente o Quadro 2 apresentado anteriormente, nota-se claramente a massiva ocorrência de marcas americanas de fast food entre as principais marcas comercializadas pelas

\footnotetext{
${ }^{44}$ Optou-se por não apresenetar este gráfico em português, pois todos os termos estão traduzidos no texto e serão utilizados no trabalho em inglês.
} 
grandes operadoras do setor.

Devido a esta forte influência do mercado americano, a subcategoria dos hambúrgueres acaba sendo mundialmente o maior volume do setor. O segundo maior negócio é da culinária asiática, mas esta posição é devida ao expressivo volume do próprio mercado local (conforme comentado anteriormente).

A categoria das cafeterias também é bastante heterogênea. Nesta categoria estão agrupados estabelecimentos como o restaurante por quilo brasileiro (e restaurantes buffet), as padarias (no conceito brasileiro), as in store dining places, as lanchonetes e as lanchonetes de beira-deestrada. Apesar de nomes importantes como as redes europeias Funch (francesa) e Tank and Rast, especialistas em atendimento ao longo de estradas, a categoria de cafeterias é fraca em marcas de expressão. Devido a esta característica, a Euromonitor (2011) refere-se às cafeterias de maneira geral, como a largely unbrended category... Profissionais ambulantes estão representados na categoria de street stalls/kiosks. Novamente, pelo fato de a cultura asiática ser bastante receptiva a esta alternativa, esta categoria passa a ter expressão global.

\subsubsection{A Classificação segundo o Anuário de Alimentação Fora do Lar}

O Anuário de Alimentação Fora do Lar de 2013 também sugere uma segmentação para a atividade de food service. Esta publicação nacional indica quinze 'canais' (termo usado pela publicação em sua classificação), compondo o setor $^{45}$ (FARIA, 2013, p. 27). O Anuário não aponta subcategorias (ou sub-canais) e acaba mesclando os caráteres de produto e serviço em sua proposta. Para o Anuário, os agentes que atuam no mercado podem ser agrupados em:

- Restaurantes comerciais

- Cadeias de fast food

- Padarias, confeitarias.

- Bares

- Lanchonetes

- Pizzaria e delivery,

- Hotéis / motéis

${ }^{45}$ A publicação não fornece detalhes sobre a metodologia usada para segmentar o mercado de food service. 
- Rest. de empresas/empresas de ref. coletivas

- Catering aéreo e de transportes

- Governamentais e merenda escolar

- Saúde e hospitais

- Conveniência

- Doceria e quiosque

- Sorveterias e chocolaterias

- Vending

\subsubsection{A Classificação das atividades do setor segundo o USDA}

O Departamento de Agricultura do Governo Americano também sugere uma classificação. Nesta proposta, fica patente a preocupação com o tipo de serviço sendo prestado, que assume a posição de principal característica para agrupar os agentes. Para o USDA, os segmentos são: (UNITED STATES DEPARTMENT OF AGRICULTURE, ECONOMIC RESEARCH SERVICE, 2014a; 2014b):

- Full-service restaurants (restaurantes com serviço completo);

- Limited-service eating places (restaurantes com serviço parcial)

- Hotels and motels (hotéis e motéis)

- Schools and colleges (escolas e faculdades)

- Stores, bars, and vending machines (lojas, bares e outo serviços)

- Recreational places (entretenimento)

- Others, including military outlets (outros, incluindo as facilidades militares)

\subsubsection{A Classificação das atividades do setor segundo a CHD Expert}

A empresa especializada em oferecer informações de mercado para o setor de alimentação, CHD Expert, usa uma classificação própria. A empresa sugere que, antes de realizar qualquer classificação, deve-se separar o mercado institucional e comercial. Para o mercado comercial, a CHD Expert usa uma classificação parecida com o USDA, reforçando o tipo de serviço como fator principal para categorização, utilizando os termos Full Service e Limited Service, 
exatamente da mesma forma como faz o USDA. O tipo de produto é usado somente para apontar os subgrupos de cada segmento, assim como faz a Euromonitor (CHD EXPERT, 2014).

Na classificação da CHD Expert, os segmentos são:

- Full service restaurants - FSR (restaurantes com serviço completo)

- Limited service restaurants - LSR (restaurantes com serviço parcial)

- Lodging (acomodações e hotelaria)

- Transport food service (alimentação para viajantes e indivíduos em trânsito)

- Food service on concession, leisure, sport, cultural sites (locais de recreação)

- Event catering, party service (alimentação em eventos)

- Bars / Adult beverages oriented outlets (bares adultos)

\subsection{A experiência de consumo de serviços}

As atividades que se propõem a oferecer serviços aos seus consumidores, como é o caso da atividade de food service, têm sempre um ponto comum: o desafio de oferecer um produto intangível. Hoffman et al. (2009) explicam que os produtos comercializados podem ser divididos em: bens e serviços, e, a diferença entre eles seria a 'carga' de intangibilidade de cada um. Na prática não existiriam produtos puramente tangíveis, ou intangíveis, mas sim, um continuum em que a tangibilidade iria decaindo dos produtos predominantemente tangíveis (bens) para os produtos predominantemente intangíveis (serviços). Nesta ótica, Shostack (1977) caracteriza a atividade de food service como uma atividade que deve ocupar uma posição central neste continuum, dado que a atividade exibe tanto características tangíveis como intangíveis.

Bens como carros são mais tangíveis e podem ser facilmente avaliados por eventuais compradores ex-ante. Já os serviços, como um corte de cabelo, têm um teor de intangibilidade maior e fica muito difícil para um comprador avaliar seus atributos ex-ante. Assim, o comprador somente consegue efetivamente avaliar um produto intangível experimentando-o. Desta forma, o processo de experimentação (a experiência do serviço, ou, a experiência do consumo de serviços) passa a ser um ponto crítico na dinâmica do consumo de serviços 
(HOFFMAN et al., 2009).

Langeard et al. (1981) sugerem quatro determinantes para a experiência de serviços: a estrutura visível (servicescape), a equipe de atendimento, os outros clientes e os sistemas e organização das empresas.

A experiência de serviços é um processo que ocorre em local determinado. No caso de food service, ocorre geralmente nas dependências do restaurante, e percebe-se que a estrutura física visível deste local, bem como a ambientação, influenciam a percepção do consumidor.

O segundo fator que influencia diretamente a percepção do cliente durante a experiência de consumo é a equipe de contato, que promove a interação entre o cliente e a prestadora de seviço. A equipe de contato (atendimento) é responsável por transferir as informações entre as partes e representar a prestadora frente ao cliente (THOMPSON, 1967); desta forma, acaba participando e influenciando diretamente o processo.

Alinhados a Grove e Fisk (1997), o terceiro determinante sugerido por Langeard et al. é a presença de outros clientes na experiência de serviço de um dado consumidor. Observando estes três primeiros determinantes, pode-se afirmar que o processo também poderia ser descrito como um 'encontro', em que o cliente interage com o prestador de serviços e com os outros clientes, gerando uma experiência única.

Além de uma estrutura física, da equipe de atendimento e dos outros clientes, para que a experiência ocorra a contento, a prestadora deverá oferecer sistemas e a organização processual necessária. Para Langeard et al. (1981) este último item (sistemas e organização) é o único determinante da experiência de consumo não visível aos olhos do cliente.

\subsection{Ambiente institucional brasileiro}

Como a maioria dos mercados, o setor de food service é fortemente influenciado pelo ambiente institucional. Dois pontos sobre o setor merecem destaque: o hábito (preferência) alimentar da população e o padrão de higiene e limpeza exigido dos estabelecimentos 
comerciais dedicados à alimentação fora do lar.

O primeiro, a influência do hábito peculiar de cada povo e de cada região, remete às intuições informais de North $(1990 ; 1994)$. É a cultura específica de cada região que faz da China a campeã em estabelecimentos do tipo FSR e fez dos EUA o berço do fast food.

A outra faceta do ambiente institucional, agora ligada às instituições formais, é a legislação sanitária. Como a segurança alimentar está ligada a inúmeros padrões de higiene, limpeza e boas práticas nos processos fabris (industriais ou artesanais), a legislação que estabelece os padrões a serem seguidos no que tange à alimentação é muito importante. O Governo é responsável pela legislação que se aplica ao setor e o órgão da Vigilância Sanitária é responsável por supervisionar e fazer cumprir as leis em questão.

A seguir, no Capítulo 6, será apresentada uma revisão específica de como a Teoria Neoinstitucionalista vem discutindo o arranjo híbrido baseado em franchising. 


\section{ECONOMIA DAS ORGANIZAÇÕES E FRANQUIAS (Franchising Economics)}

Conforme apontado no capítulo anterior, de acordo com a Euromonitor (2011; 2012), 90\% das redes de food service têm parte de suas operações sob contrato de franquia. Desta forma, dada a magnitude dessa opção pelo arranjo franqueado, a seguir será feita uma breve revisão do conceito de franquia e de como a teoria econômica aborda especificamente a questão do franchising.

\subsection{A franquia}

Basicamente, pode-se classificar as franquias como Tradicionais e como franquias de Modelo de Negócio (ZOTT; AMIT; MASSA, 2010). Essa classificação somente é válida para os países que reconhecem o modelo de distribuição por meio de concessionárias e distribuidoras como sendo parte do modelo de franquias.

Concessionárias que revendem automóveis e postos que distribuem combustíveis são um bom exemplo do que se considera uma franquia tradicional nos Estados Unidos (BLAIR; LAFONTAINE, 2005), em que a venda de produtos entre o franqueador e o franqueado é o ponto fundamental da relação entre estes dois agentes. Já a franquia de Modelo de Negócios não exige comercialização de produtos entre os pares, e tem como característica principal o uso da marca e da estrutura de negócios do franqueador por seus franqueados (ZOTT; AMIT; MASSA, 2010). A imensa gama de cadeias de fast food, como McDonald`s e Burger King, são exemplos de franquia de modelo de negócios.

\subsubsection{O contrato de franquia}

O contrato de franquia estabelece uma relação comercial entre dois agentes: o franqueador (franchisor) e o franqueado (franchisee). Esta relação comercial é regulada por leis, como, no Brasil, a Lei $\mathrm{n}^{\circ}$ 8.955/94 do Ministério do Desenvolvimento, da Indústria e do Comércio Exterior que dispõe sobre as responsabilidades básicas de franqueador e franqueado, em uma 
relação deste tipo. De acordo com a legislação brasileira, os termos: franchising, sistema de franquias e franquia empresarial devem ser tomados como sinônimos (MINISTÉRIO DO DESENVOLVIMENTO DA INDÚSTRIA E DO COMÉRCIO EXTERIOR, 2006).

Conforme a descrição de Rubin (1978), Silva e Azevedo (2006; 2007), Blair e Lafontaine (2005) e Vance (2010), nesta relação comercial o franqueador transfere alguns direitos ao franqueado, tais como: o direito ao uso de sua marca e/ou o direito ao acesso ao seu modelo de negócio, para que o franqueado explore comercialmente este negócio em determinada praça, por um determinado período de tempo.

Já o franqueado compromete-se a exercer de fato a exploração do negócio arcando com os custos da operação (ex.: investimentos para abrir uma loja, como: ponto comercial, reforma do ponto para adequar-se ao padrão da rede, compra de equipamentos e capital de giro). $\mathrm{O}$ franqueado também fica responsável pela operacionalização do negócio, ou seja, o dia a dia da operação, comprometendo-se a seguir o modelo de negócios do franqueador (respeitando seu padrão de qualidade, não tomando atitudes que possam desgastar sua marca frente ao público), além de comprometer-se a remunerar o franqueador a partir de uma forma de pagamento composta pela soma de uma taxa de franquia, taxa de royalties e taxa de propaganda.

A taxa de franquia é um valor fixo (lump sum) inicial pago ao franqueador e representa a entrada do franqueado na rede. Assim, ele passa a ter acesso ao modelo de negócios e a ter direito ao uso da marca. Os royalties são uma taxa mensal, geralmente uma porcentagem do faturamento da operação, que é destinada ao franqueador. Os royalties também podem ser calculados como uma porcentagem sobre as compras efetuadas pela operação, ou mesmo estarem embutidos no valor de insumos que o franqueado deva adquirir do franqueador. A taxa de propaganda (ou publicidade) é mais uma taxa mensal sobre o percentual vendido e deverá ser usada pelo franqueador em seu esforço de marketing para a rede como um todo.

Ménard (2004; 2010) descreve o uso do contrato de franquia como sendo padronizado, apresentando pouca variação (ou nenhuma) internamente à rede e pouca variação entre redes diferentes também. Devido a esta pouca variação contratual, Ménard (2010) sugere que para captar os nuances da relação entre franqueado e franqueador é necessário ficar atento aos componentes não contratáveis do acordo, além do que está formalizado no contrato. 


\subsection{Franchising e Teoria da Agência}

Apesar de a Teoria da Agência não ser parte da NEI, vale comentar sua perspectiva em relação ao franchising, por ela ser muito utilizada em estudos acadêmicos que discutem este assunto e por ser comumente usada de maneira complementar à $\mathrm{ECT}^{46}$. Deve-se frizar que a proposta aqui não é detalhar a análise do franchising a partir da Teoria da Agência, mas apenas apontar os principais pontos de sua utilização, pois ela, efetivamente, não faz parte da base teórica que suporta o modelo de Ménard.

Proposta inicialmente por Rubin (1978), a perspectiva do franchising dada pela Teoria da Agência seria uma resposta ao problema de monitoramento das unidades de uma cadeia. Devido ao custo altíssimo de se monitorar unidades dispersas, a firma adotaria o arranjo de franchising para que surgisse um dono em cada unidade (loja) da rede, que teria todo interesse em monitorar a operação de sua unidade.

O problema de monitoramento de cada unidade fica resolvido, mas surge outro tipo de problemática do tipo Agente e Principal a ser considerado: a relação entre o franqueador (Principal) e o franqueado (Agente). Nesta relação, o agente passa a ter acesso à marca e ao modelo de negócios do principal, enquanto o principal se compromete a cuidar da gestão da rede. Havendo assimetria de informação na relação, surge um problema de agência típico de risco moral (risco de oportunismo pós-contratual) (RUBIN, 1978; LAFONTAINE, 1992; LAFONTAINE, SLADE, 1997; LAFONTAINE, SHAW, 1999; GIBBONS, 1998; GIBBONS, 2005; SILVA, AZEVEDO, 2007; AZEVEDO, 2009; VANCE, 2010).

\subsection{Franchising e a Economia dos Custos de Transação}

Williamson (1996) e Ménard (2004; 2010) sugerem que o franchising deve ser visto como uma situação de relação bilateral entre dois agentes: o franqueado e o franqueador. Nesta ótica, os agentes fazem investimentos específicos, dando origem a uma relação contratual híbrida. O franqueador investe em sua marca (especificidade de marca), enquanto o franqueado investe seu tempo (especificidade humana) e aporta o capital necessário para manter sua unidade da rede (especificidade física).

\footnotetext{
${ }^{46}$ Como fazem, por exemplo: Silva e Azevedo (2007); Azevedo (2009) e Vance (2010).
} 
Conforme observado no capítulo anterior, a complementaridade entre os investimentos específicos cria o incentivo para cooperação entre os agentes, dando a possibilidade da formação de uma cadeia, em que o franqueador relaciona-se com inúmeros franqueados, bilateralmente, ao mesmo tempo. Por outro lado, cada agente passa a se preocupar em proteger seus direitos de propriedade contra possíveis ações oportunistas por parte de seus parceiros comerciais. Adicionalmente, eles ainda terão de lidar com os desafios de coordenação da ação conjunta e de alocação de pay off (MÉNARD, 2010).

\subsection{Alocação de autoridade em franchising}

Como no caso do estudo das hierarquias, a centralização também é um ponto de interesse quanto se trata de compreender arranjos híbridos baseados em franquia. Conforme aponta Azevedo (2009), compreender a racionalidade do processo de alocação de autoridade em cadeias franqueadas é fundamental para o conhecimento deste tipo de arranjo. $\mathrm{O}$ referido autor contribui para a compreensão do processo de alocação de autoridade em redes franqueadas sugerindo que as redes, cuja necessidade de estandardização é maior (como no caso de redes cujas marcas têm maior valor), tendem a ser mais centralizadas.

Uma contribuição específica de Azevedo (2009) no estudo da descentralização está na proposta de um índice de delegação de autoridade. A Figura 13, apresentada a seguir, ilustra a composição do índice, em que o aumento do: monitoramento, da incidência de lojas próprias e das prescrições do manual do franqueado, levaria à centralização.

( $\uparrow N^{3}$ de lojas próprias / lojas franqueadas

( $\uparrow$ Tarefas do Manual do Franqueado $\succ(\downarrow)$ Delegação

( ) Intensidade do monitoramento 


\subsubsection{ECT e alocação de autoridade}

Uma proposta que deve ser considerada quando se discute alocação de autoridade em cadeias franqueadas é a proposta de Grossman, Hart e Moore (doravante: GR\&M) sobre o processo de barganha por direitos de propriedade em relações marcadas por investimento específico (GROSSMAN, HART, 1986; HART, MOORE, 1990). Para os autores, a centralização dos direitos de propriedade neste tipo de situação é mais eficiente quando o agente, cujo investimento específico foi maior, integrar os direitos de propriedade em jogo.

Usando a ideia básica sugerida por GH\&M, se a franquia for vista conforme sugerem Williamson (1996) e Ménard (2010), isto é, como um arranjo híbrido em que há investimento específico por ambos os agentes de uma relação bilateral entre franqueado e franqueador, estes agentes irão barganhar pelos direitos de propriedade pertencentes ao arranjo. Nessa barganha, quanto maior for o investimento específico feito por um agente, maior será seu esforço para controlar os direitos de propriedade em jogo na relação.

\subsection{Controle em redes franqueadas}

Aghion e Tirole (1997) observaram que existe uma diferença entre um agente ter formalmente um direito de decisão e ter efetivamente o controle sobre esta decisão. Neste sentido, não basta um agente ter um direito de decisão, é necessário haver condições (mecanismos) que garantam o exercício real deste direito.

Azevedo (2009) sugere que se deva adotar esta perspectiva defendida por Aghion e Tirole (1997) quando se discute a alocação de autoridade em cadeias de franquiadas. Para Azevedo, quanto mais intensa for a capacidade de monitoramento do franqueado pelo franqueador, maior será sua capacidade de exercer seus direitos (controle real) e maior será a centralização do arranjo. 


\subsection{Diferentes arranjos baseados em franchising}

Ao discutir as diferenças entre o franchising brasileiro e francês, Silva e Azevedo (2007) identificaram pelo menos três categorias de arranjos baseados em franquia: a franquia convencional, a franquia parcial e a locação de gerência (SILVA; AZEVEDO, 2007, p. $139^{47}$ ).Para esses autores, o contrato de franquia convencional segue o modelo descrito na seção anterior. Já o contrato de franquia parcial retrata um acordo em que o ponto comercial é escolhido e arrematado (compra ou aluguel) pelo franqueador, deixando todos os outros custos (e responsabilidades operacionais) para o franqueado. Por fim, o contrato de locação de gerência celebra um acordo em que, além de arrematar o ponto comercial, o franqueador também se responsabiliza pelos custos da operação, como: reforma, equipamentos e capital de giro. Assim, cabe ao franqueado apenas operacionalizar o dia a dia de sua unidade.

\subsection{Ambiente institucional e franchising}

O mesmo trabalho de Silva e Azevedo (2007) também pode ser apontado como um exemplo de mais uma linha de estudo econômico do franchising: o estudo da influência do ambiente institucional sobre esta forma híbrida. Neste trabalho os autores compararam operações em food service no Brasil e na França, apontando a relevância da influência do ambiente institucional na escolha das estruturas de governança.

${ }^{47}$ Quadro disponível no Anexo I. 


\section{ANÁliSE EMPÍRICA: A ALOCAÇÃo DE AUTORIDADE EM CADEIAS FRANQUEADAS}

\subsection{Retomando o problema de pesquisa e objetivos}

Conforme apresentado no Capítulo de Introdução, o problema de pesquisa deste trabalho pôde ser resumido na seguinte indagação:

O que determina a alocação de autoridade em cadeias de franquias no setor de food service?

Para responder a este problema de pesquisa, elegeu-se a linha teórica desenvolvida por Claude Ménard (2004; 2010) para o estudo das formas híbridas, no intuito de discutir a alocação de autoridade no setor de food service, especialmente em cadeias que adotam a franquia como estratégia organizacional. A rigor, o objetivo final desta discussão será propor um modelo econômico $^{48}$ sobre o que estaria determinando a escolha de forma organizacional feita por estes agentes.

De acordo com o que foi abordado nos Capítulos 3 e 4, dedicados aos trabalhos de Ménard (2004; 2010), o autor vê as formas híbridas como uma classe de formas organizacionais, com características de governança próprias, sendo determinadas pela alocação de autoridade no arranjo, o que está totalmente alinhado à discussão pretendida no problema de pesquisa deste trabalho.

Além do alinhamento teórico em função da alocação de autoridade, o fato de Ménard (2004; 2010) ver as formas híbridas como uma classe organizacional implica a aceitação da relevância das características do setor de cada firma na análise, o que garante o alinhamento com a preocupação específica do problema de pesquisa com o setor de food service.

\footnotetext{
${ }^{48}$ Deve-se esclarecer que o termo 'modelo econômico' usado na proposição do objetivo deste trabalho refere-se a um 'modelo de racionalidade econômica'e não a um 'novo modelo para a economia'.
} 


\subsection{Hipótese}

A hipótese do trabalho sobre quais os determinantes da escolha da forma organizacional pelos agentes surge a partir da observação do setor de food service, sob a perspectiva proposta por Ménard (2010).

A observação indireta, feita a partir de contato com dados secundários, gerou a revisão apresentada nos Capítulos 5 (O setor de food service). Para complementar esta revisão, foi feita uma entrevista de caráter exploratório na empresa de consultoria em franchising: Francap, no mês de fevereiro de 2014, tendo como entrevistado o Sr. André Friedheim, sócio diretor da empresa.

A Francap é uma empresa de consultoria que desenvolve planos de expansão para agentes que desejam optar pelo sistema de franquia, mas não têm todo conhecimento necessário para fazêlo independentemente. A empresa foi pioneira no setor que atua, desenvolvendo este trabalho há mais de 20 anos (FRANCAP, 2014). Além de oferecer o serviço de consultoria, a Francap também atua como gestora de operações em alguns empreendimentos no setor de franquias, principalmente em food service.

A entrevista com a Francap pode ser caracterizada como uma entrevista em profundidade, que foi estruturada seguindo os seguintes tópicos: a) características do setor de franchising no Brasil, b) contrato de franquia e c) formas organizacionais em food service no Brasil e no mundo. A discussão destes tópicos com o entrevistado gerou um melhor entendimento do funcionamento do setor e trouxe um conhecimento mais detalhado sobre os tipos de formas organizacionais efetivamente adotadas pelos agentes.

Com base na revisão sobre franchising economics (Capítulo 6), na revisão sobre as características do setor de food service (Capítulo 5), e na entrevista com a Francap, foi proposto um constructo para caracterizar uma unidade qualquer de food service. Este constructo é formado pelos dois elementos fundamentais que definem um restaurante: seu caráter fabril (manipulação dos alimentos) e seu caráter de serviços (atendimento).

A este constructo foi dado o nome de Complexidade no Ponto de Venda (CPV). A hipótese 
deste trabalho é que sua relação com a alocação de autoridade nas cadeias de food service segue a seguinte lógica:

H: Quanto maior a complexidade no ponto de venda, maior a descentralização esperada numa rede de franquias de food service

A seguir, será discutida a composição do constructo de complexidade para, posteriormente, retomar a discussão da hipótese recém-proposta.

\subsubsection{A complexidade no ponto de venda}

A Figura 14, apresentada a seguir, ilustra as características captadas pelo constructo de complexidade proposto.

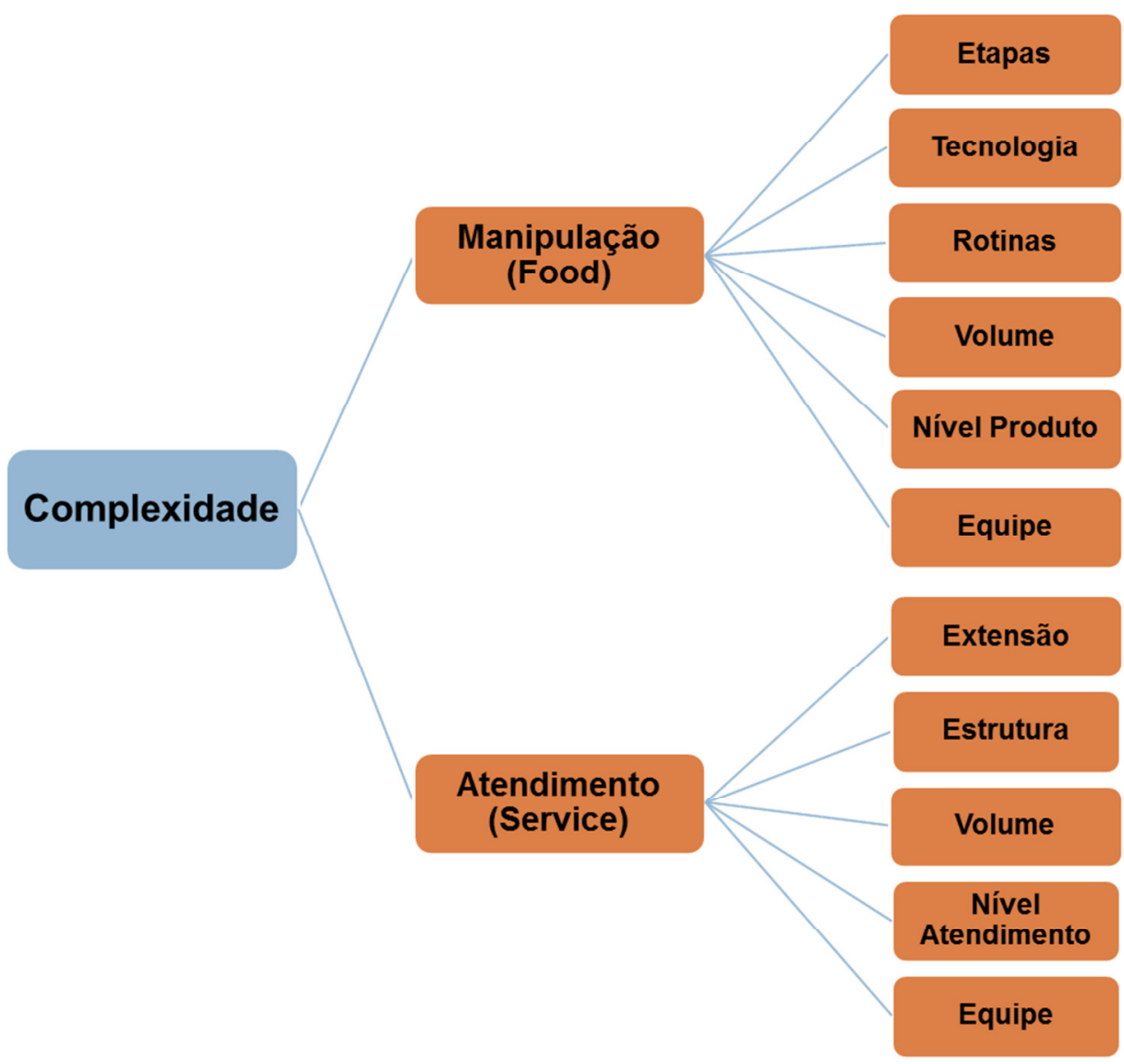

Figura 14 - Complexidade no ponto de venda

Fonte: elaborado pelo autor 
A ideia básica deste constructo é a de que: (i) as situações que necessitam de mais conhecimento específico para serem geridas são mais complexas; (ii) as decisões que têm um leque maior de possibilidades de resposta são mais complexas; (iii) os processos que envolvem um maior número de decisões, interações e transações, as quais exigem um esforço maior dos gestores para chegar a um fim, são mais complexos.

\subsubsection{O caráter fabril}

O caráter fabril do constructo é determinado pelo número de etapas do processo de produção, pela tecnificação ${ }^{49}$ do restaurante, pela intensidade na adoção de rotinas operacionais, pelo volume de alimentos produzido em determinado nível de qualidade e pelo tamanho da equipe envolvida nessa atividade.

Um processo fabril pode ter mais ou menos etapas a serem percorridas na cozinha de um restaurante. Quanto mais etapas, mais esforço é exigido de sua equipe. Quanto mais etapas, maior a possibilidade de erros.

Um restaurante pode ser mais ou menos tecnificado. Algumas casas ${ }^{50}$ produzem seus pratos de maneira artesanal, sem qualquer utilização de tecnologia. Outras casas, como por exemplo: as cadeias de fast food, são intensamente tecnificadas, utilizando utensílios desenvolvidos especialmente para aumentar sua produtividade, assim como máquinas e tecnologia da informação. Desta forma, quanto mais artesanal for uma cozinha, maior será a dificuldade de operá-la e maior será a complexidade no ponto de venda.

A adoção de rotinas também é um elemento que deve ser observado para retratar o caráter fabril de um restaurante. Rotinas podem ser usadas em cozinhas tecnificadas ou não. Os restaurantes que investem em desenvolver e implantar rotinas têm menos variação na tomada de decisão em suas cozinhas, devido ao maior nível de codificação dos processos e das tarefas impostas às suas equipes (TEECE; PISANO; SHUEN, 1997). Cozinhas que adotam rotinas

\footnotetext{
${ }^{49}$ Indica a intensidade de uso de tecnologia no processo fabril.

${ }^{50}$ Termo usado pelos agentes do setor de food service para designar um estabelecimento comercial (restaurante).
} 
são mais fáceis de gerenciar, denotando uma menor complexidade no ponto de venda.

O volume de alimentos produzido numa cozinha também influencia a dificuldade em operála. Mantendo a estrutura tecnológica constante, se houver um aumento significativo da produção, o gerenciamento de um fluxo maior de insumos, e de um número maior de funcionários para operar a cozinha, irá gerar um aumento na complexidade operacional. A sofisticação dos pratos também influencia no esforço operacional a ser feito, sendo mais difícil manter níveis altos de qualidade e sofisticação culinária.

Um fator particular é o número de funcionários envolvidos na manipulação dos alimentos. Quanto maior a equipe de funcionários dedicada à atividade de produção num restaurante, maior a dificuldade de gerenciamento desta loja.

\subsubsection{O caráter de serviços}

O caráter de serviços do constructo é determinado pela extensão do atendimento, pela estrutura deste atendimento, pelo volume de clientes atendidos no restaurante a certo nível de atenção e pelo tamanho da equipe envolvida nessa atividade.

O serviço oferecido num restaurante pode variar quanto à sua extensão. Em um restaurante full service o atendimento é completo e a equipe interage com o cliente durante toda sua experiência de consumo. Já a proposta de um restaurante fast food é mais limitada, e a equipe interage com o cliente só até o momento em que ele recebe seu prato, deixando-o sem atendimento durante o ato de consumo. A proposta de um quiosque é mais simples ainda, pois não existe atendimento nem estrutura para acomodar o ato de consumo, assim, quando uma pessoa compra um alimento num quiosque, ela o carrega para consumir em outro local.

Quanto maior a extensão do atendimento, maior deverá ser o esforço da equipe em servir o cliente. Desta forma, quanto mais extenso o atendimento, mais complexo o ponto de venda.

O nível do atendimento também é determinante. Quanto mais sofisticado o atendimento, maior o esforço exigido, e, quanto mais clientes a atender numa mesma loja, idem. 
Em food service, o atendimento tem um componente típico, além do contato humano, que é a estrutura física do restaurante. Tal estrutura engloba a decoração do ambiente, a disponibilidade de mesas e cadeiras, de banheiro etc. Um restaurante com salão próprio oferece mais comodidade (atendimento) do que um box $x^{51}$ em uma praça de alimentação.

Quanto mais estrutura, maior o esforço em manutenção. Desta forma, quanto maior a estrutura, maior a complexidade do ponto de venda. Seguindo o mesmo racional do carácter fabril, quanto maior a equipe de funcionários dedicada à atividade de atendimento num restaurante, maior a dificuldade de gerenciamento a loja.

A Figura 15, apresentada a seguir, ilustra a relação de cada um dos onze itens que compõe o constructo com a complexidade resultante esperada para um dado ponto de venda. Nota-se uma contribuição positiva da maioria dos itens do construto (todos, exceto: tecnologia e rotinas) na complexidade final esperada.

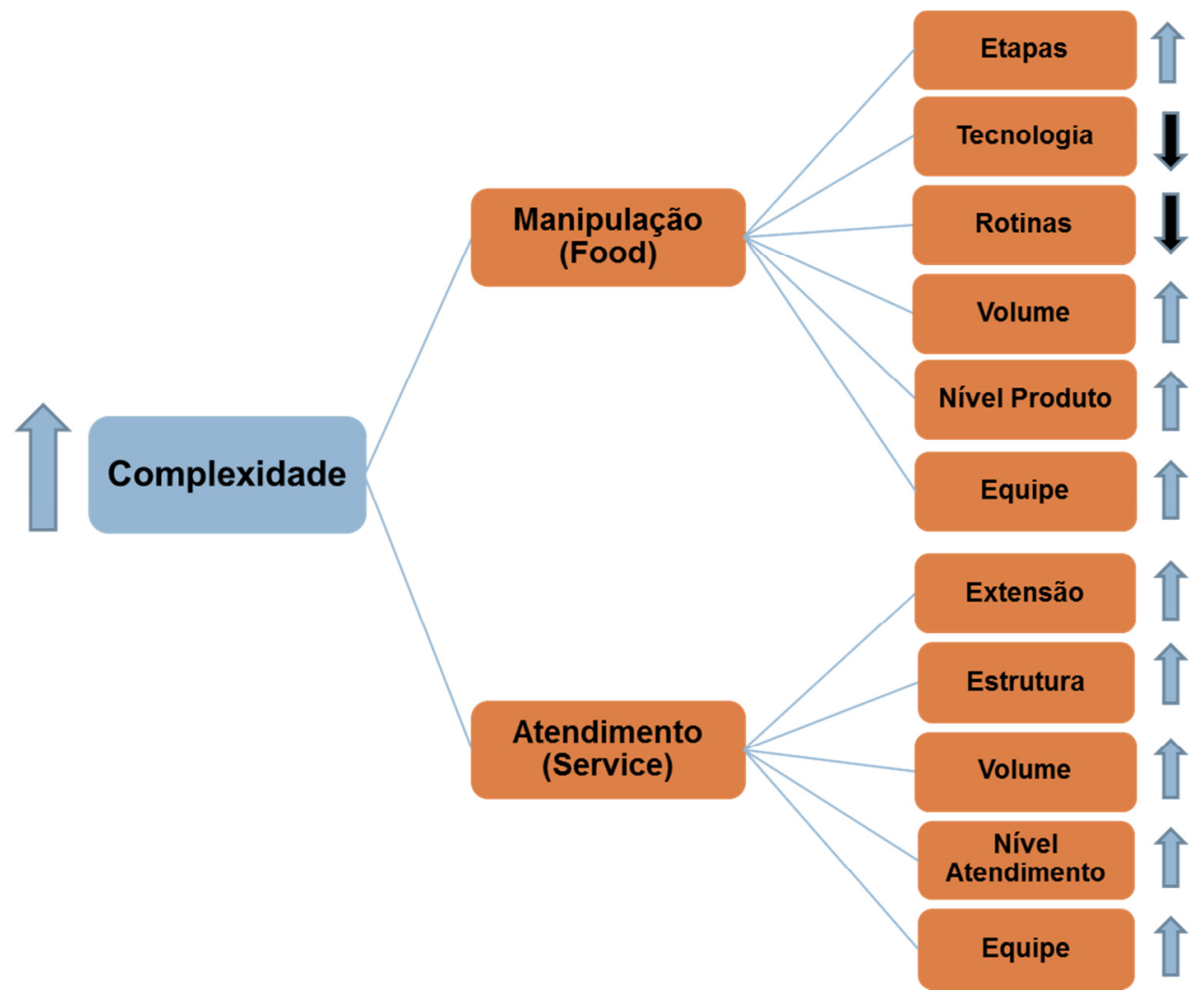

Figura 15 - A influência das variáveis no constructo de CPV

Fonte: Elaborado pelo autor

\footnotetext{
${ }^{51}$ Termo usado pelos agentes do setor de food service para designar uma lója tópica (restaurante) de shopping center sem salão próprio.
} 


\subsubsection{A relação entre complexidade e descentralização}

Conforme apontado anteriormente, na proposição da hipótese deste trabalho, espera-se observar um aumento na descentralização das cadeias de food service que operam restaurantes mais complexos. A racionalidade econômica por trás dessa relação segue a proposta de Grossman, Hart e Moore, apresentada em detalhes no Capítulo 6, Seção 6.4.1, em que os autores apontam o agente responsável pelo maior investimento específico como o maior interessado em verticalizar a produção para ficar com os direitos residuais (já que tal investimento específico é o responsável pela renda gerada).

Conforme colocado no Capítulo 6, numa relação de franquia em food service, o investimento específico ocorre da seguinte maneira: a matriz investe na marca (especificidade de marca) e no desenvolvimento de seu sistema e o franqueado faz um investimento específico no restaurante (especificidade física) e se dispõe a atuar como operador (especificidade humana).

Desta forma, seguindo a visão de Grossman, Hart e Moore, espera-se que, em uma cadeia de food service, os franqueados sejam mais ávidos por contratos que lhes confira uma porção maior de direitos de propriedade sobre o arranjo, quanto maior for seu investimento específico humano e físico.

A complexidade no ponto de venda participa deste racional como uma proxy para restaurantes que exigem alto investimento específico dos operadores (franqueado). Quanto mais complexo o ponto de venda, maior a necessidade de dedicação do franqueado no dia a diado restaurante (maior o investimento em especificidade humana). Quanto mais complexo o ponto de venda, maior o investimento necessário em estrutura física (especificidade física).

Vale comentar que também é possível encontrar uma referência sobre esta posição esperada do franqueado na pesquisa de Azevedo (2009, vide detalhes na p. 16). Ao comparar o desafio de gerenciar uma unidade franqueada de um hotel com uma unidade franqueada de uma pequena loja de sorvetes, o autor sugere que o desafio de lidar com um número maior de tarefas (hotel) deve exigir maior alocação de autoridade junto ao operador (franqueado). 


\subsection{Metodologia}

Este trabalho visa avaliar a descentralização em cadeias de franquias do setor de food service, qualitativamente. Para tanto, foi desenvolvido um estudo de múltiplos casos, que usa como ferramenta de análise o modelo de Ménard (2010). Yin (1989) indica a metodologia de estudo de múltiplos casos para situações em que o pesquisador deseja captar insights sobre certos fenômenos a partir de uma observação particular, tentando propor ideias passíveis de generalização a partir do estudo de casos específicos.

Baker e Gil (2012) também discutem a aplicação desta metodologia, classificando os estudos de caso como casos clínicos quando estes são capazes de encaminhar os seguintes desafios: a) descrever para os pesquisadores qual é o modelo teórico que querem propor; b) fornecer um guia de como modelar um determinado fenômeno; c) analisar a possibilidade de formular teoremas; d) providenciar evidências para testar novas hipóteses/teorias (BAKER; GIL, 2012, p.196).

Tendo como objetivo gerar um modelo sobre as determinantes da escolha organizacional em cadeias de food service, a escolha do estudo múltiplo de casos fica sendo uma escolha bastante alinhada à proposta de casos clínicos recém-apresentada, especialmente no tocante aos itens 'a'e 'b', propostos por Baker e Gil (2012).

A escolha da metodologia de estudo de múltiplos casos também converge com a proposta de Ménard (2010), que vê as formas híbridas como uma classe organizacional, em que a comparação entre casos permite identificar as características da família de estruturas como um todo.

\subsubsection{Amostra}

Tendo definido como objeto de estudo o sistema de franquias do setor de food service brasileiro, foram eleitos três casos para compor o trabalho. A escolha dos casos foi pautada pela aparente complexidade no ponto de venda de cada cadeia e foi dada preferência aos casos 
cujas CPVs fossem diferentes entre si, para que a comparação entre suas estratégias organizacionais pudesse ser a mais rica possível. Deste modo, foram escolhidos os casos de: uma pizzaria delivery, uma cafeteria e uma hamburgeria, para compor o estudo, tendo como condição eletiva o uso do sistema de franquia como, pelo menos, parte de seu design organizacional. A escolha foi feita tendo a expectativa de que a hamburgeria teria a maior CPV e que a pizzaria delivery teria a menor CPV, entre os componentes do estudo.

\subsubsection{Método de análise}

Collis e Hussey classificam o método de análise de estudos que discutem um fenômeno, qualitativamente, sob uma determinada perspectiva teórica como: Procedimento Analítico Geral (COLLIS; HUSSEY, 2005 p. 246). Neste trabalho, conforme discutido na seção anterior, esta perspectiva teórica será dada pela utilização do modelo de Ménard (2010) como ferramenta capaz de avaliar a descentralização em cadeias de franquias.

Ménard (2010) caracteriza as organizações híbridas de acordo com a forma como os direitos de propriedade estão alocados no arranjo. Desta forma, o autor oferece um framework para avaliar o processo de descentralização, em que se deve esperar a incidência dos mecanismos de governança apontados pelo autor, conforme o nível de descentralização.

Como visto no Capítulo 4, os mecanismos de governança do Modelo de Ménard (2010) são: o contrato, os centros estratégicos, as third parties e as redes de informação. Para o autor, formas organizacionais centralizadas terão contratos detalhados ex-ante, deixarão pouco espaço para acertos ex-post, além de utilizarem pouco seu caráter relacional na interação entre os agentes.

No modelo de 2010, o mecanismo de centro estratégico é o escolhido em arranjos mais centralizados. Em casos de centralização intermediária, o mecanismo mais adequado seria a third party, e, em casos de baixa centralização o mecanismo minimizador de custos de transação seria a rede de informação. 
O Quadro 3, apresentado a seguir, resume a incidência dos mecanismos de governança, podendo ser usado como guia para classificar os arranjos observados. Neste quadro, o caráter de complementariedade entre os mecanismos, tão defendido por Ménard $(2004 ; 2010)$, é contemplado, evidenciando as possíveis combinações que ocorreriam à medida que a centralização $^{52}$ de um dado arranjo aumentasse.

\begin{tabular}{|c|}
\hline $\begin{array}{c}\text { Contratos } \\
\text { Relacionais }\end{array}$ \\
\hline $\mathbf{x x x x x x x}$ \\
\hline $\mathbf{x x x x x x}$ \\
\hline $\mathbf{x x x x x}$ \\
\hline $\mathbf{x x x x}$ \\
\hline $\mathbf{x x x}$ \\
\hline $\mathbf{x x}$ \\
\hline $\mathbf{x}$ \\
\hline
\end{tabular}

\begin{tabular}{|c|c|c|}
\hline $\begin{array}{c}\text { Information- } \\
\text { Based-Networks }\end{array}$ & Third Party & $\begin{array}{c}\text { Centro } \\
\text { Estratégico }\end{array}$ \\
\hline $\mathbf{x}$ & & \\
\hline \multirow[t]{2}{*}{$\mathbf{x}$} & $\mathbf{x}$ & \\
\hline & $\mathbf{x}$ & \\
\hline $\mathbf{x}$ & & $\mathbf{x}$ \\
\hline \multirow[t]{3}{*}{$\mathbf{x}$} & $\mathbf{x}$ & $\mathbf{x}$ \\
\hline & $\mathbf{x}$ & $\mathbf{x}$ \\
\hline & & $\mathbf{x}$ \\
\hline
\end{tabular}

Quadro 3 - Mecanismos de governança do modelo de Ménard (2010) e centralização Fonte: elaborado pelo autor, com base em Ménard (2010)

Tomando como exemplo os casos da Vivenda do Camarão e China In Box descritos por Azevedo (2009) em sua discussão sobre alocação de autoridade em cadeias franqueadas, pode-se classificá-los no modelo de Ménard (2010), conforme ilustra o Quadro 4, apresentado a seguir.

\begin{tabular}{|c|}
\hline $\begin{array}{c}\text { Contratos } \\
\text { Relacionais }\end{array}$ \\
\hline $\mathbf{x x x x x x x}$ \\
\hline $\mathbf{x x x x x x}$ \\
\hline $\mathbf{x x x x x}$ \\
\hline $\mathbf{x x x x}$ \\
\hline $\mathbf{x x x}$ \\
\hline $\mathbf{x x}$ \\
\hline $\mathbf{x}$ \\
\hline
\end{tabular}

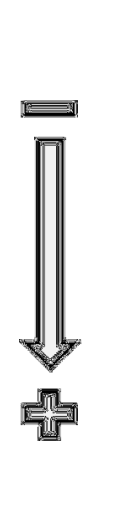

\begin{tabular}{|c|c|c|}
\hline $\begin{array}{c}\text { Information- } \\
\text { Based-Networks }\end{array}$ & Third Party & $\begin{array}{c}\text { Centro } \\
\text { Estratégico }\end{array}$ \\
\hline $\mathbf{x}$ & $\mathbf{x}$ & \\
\hline $\mathbf{x}$ & $\mathbf{x}$ & \\
\hline $\mathbf{x}$ & $\mathrm{x}$ & $\mathbf{x}$ \\
\hline $\mathbf{x}$ & $\mathbf{x}$ & $\mathbf{x}$ \\
\hline & & $\mathbf{x}$ \\
\hline & & $\mathbf{x}$ \\
\hline
\end{tabular}

China in Box

Quadro 4 - Mecanismos de governança e centralização para China In Box e Vivenda do Camarão Fonte: elabora do pelo autor, com base em Ménard (2010) e Azevedo (2009)

Azevedo (2009) descreve a China In Box como uma organização menos centralizada que a Vivenda do Camarão. Ele comenta que a China In Box utiliza bem mais as interações internas

\footnotetext{
${ }^{52}$ A flecha indica o aumento da centralização.
} 
da rede para produzir conhecimento do que a Vivenda do Camarão. A descrição de Azevedo (2009) corrobora com o Modelo de Ménard (2010), que aponta uma estrutura menos centralizada nos arranjos que utilizam uma composição de mecanismos formada por um centro estratégico e redes de informação (China in Box), contra um arranjo que utiliza predominantemente o centro estratégico (Vivenda) para coordenar sua rede.

\subsubsection{Alocação de tarefas como proxy para alocação de direitos de propriedade}

A seção anterior foi dedicada à discussão da utilização dos mecanismos de governança do modelo de Ménard (2010). Agora, resta discutir como operacionalizar a alocação de direitos de propriedade nas cadeias de food service. McElheran (2013) enfrentou um desafio parecido com este, da operacionalização de alocação de direitos de propriedade, ao estudar o processo de delegação de autoridade sobre a decisão de compra de insumos tecnológicos em empresas de varejo. A autora sugere que o processo de compra, seu objeto de estudo, seja operacionalizado a partir das principais tarefas (tasks) que o compõem. Seguindo a linha de pensamento clássica da Teoria de Direitos de Propriedade, conforme sugere Alchian $(1987)^{53}$, cada tarefa, que é facilmente observada, deve ser entendida como um conjunto de direitos de propriedade.

Para exemplificar o uso de tarefas para operacionalizar a alocação de direitos de propriedade em food service, vale conjecturar como esta proposta seria aplicada à classificação de tipos de franquias de Silva e Azevedo (2007), discutida em detalhes no Capítulo 6. Estes autores identificaram três variações de franquia: a franquia tradicional, a parcial e a alocação de gerência. Silva e Azevedo (2007) comentam que na franquia tradicional o ponto de venda, a reforma e o gerenciamento da equipe correm por conta do franqueado. Na franquia parcial, o ponto é responsabilidade da franqueadora, e a reforma e o gerenciamento da equipe continuam alocados no franqueado. Na locação de gerência, a única responsabilidade do franqueado é o gerenciamento da equipe. A escolha e a negociação do ponto, a decisão de abrir a loja (investimento) e o gerenciamento da equipe são tarefas básicas que devem ser cumpridas em qualquer cadeia de food service.

\footnotetext{
${ }^{53}$ A visão sugerida por Achian foi discutida em detalhes no Capítulo 2, Seção 2.4.
} 
A Figura 16, apresentada a seguir, ilustra as diferentes formas como estas decisões são alocadas nos arranjos definidos por Silva e Azevedo (2007).

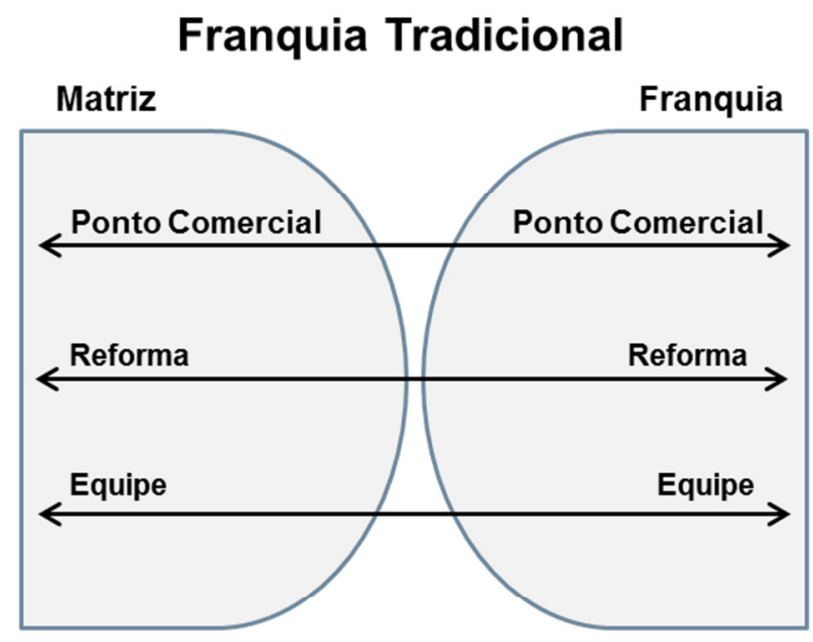

\section{Franquia Parcial}

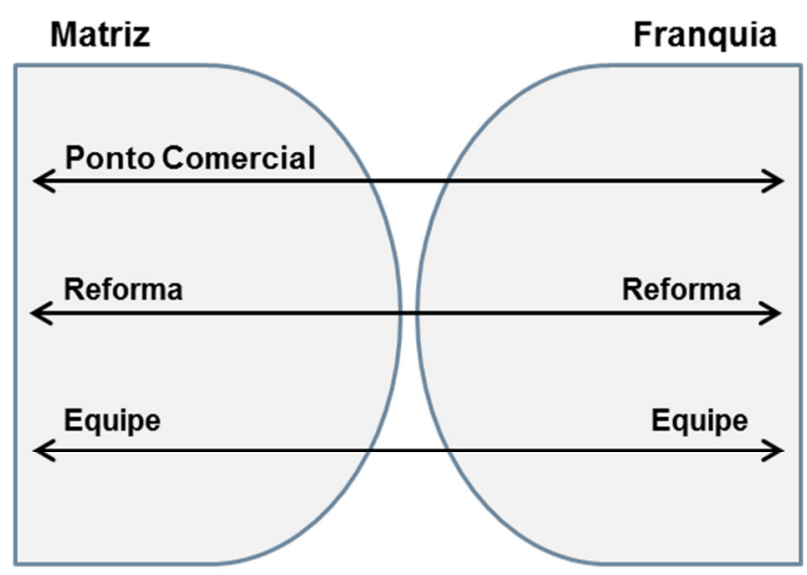

\section{Locação de Gerência}

Matriz

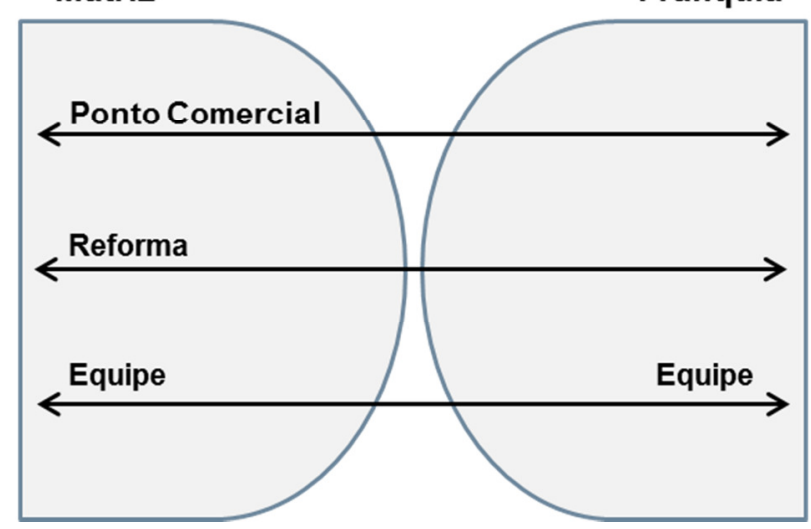

Figura 16 - Alocação de tarefas básicas em arranjos franqueados Fonte: elaborado pelo autor, com base em Silva e Azevedo (2007) 
A proposta analítica da alocação das tarefas feita nos moldes da Figura 16 é sempre binária, ou seja, somente permite dois tipos de resultado: a alocação centralizada de uma tarefa (na matriz ou na máster franquia) ou a alocação compartilhada com a periferia (dividindo a responsabilidade com a unidade franqueada ou integrada).

Em um estudo de delegação, a informação obtida a partir deste tipo de análise deverá ser capaz de ajudar a explicar a opção de design organizacional dos agentes, pois, conforme Grossman, Hart e Moore, quanto maior o investimento específico, maior a avidez por controle. $\mathrm{Ou}$, quanto maior o investimento específico de um agente, maior será sua avidez por reter direitos de propriedade do arranjo sob seu controle.

\subsubsection{2 $O$ conjunto de tarefas necessário à análise}

Tendo definido as tarefas como proxy para os direitos de propriedade, surge a necessidade de determinar o conjunto total de direitos em jogo que definem uma rede qualquer de food service, para ser possível uma comparação entre os diferentes arranjos organizacionais. No exemplo citado anteriormente, Silva e Azevedo (2007) abordaram a questão limitando-se a discutir a alocação de três tarefas. Para uma abordagem comparativa devem ser identificadas todas as tarefas pertinentes à atividade de food service e observar sua alocação.

Utilizando a divisão básica da administração de empresas nas funções de: marketing, produção, recursos humanos e finanças (MAXIMIANO, 2012), e confrontando estas funções com a revisão específica da atividade de food service contida no Capítulo 5, foram identificadas as seguintes tarefas como o conjunto básico de atividades (tarefas) desenvolvidas por um agente qualquer deste setor $^{54}$ :

- O desenvolvimento dos produtos;

- O desenvolvimento de promoções e propaganda;

- A expansão da rede e a escolha do ponto comercial;

\footnotetext{
${ }^{54}$ A identificação das tarefas será aborda em mais detalhes, ainda neste capítulo, na Seção 7.3.3, ao se discutir a elaboração do roteiro de questões para as entrevistas.
} 
- Precificação;

- Marketing de vizinhança;

- Marketing institucional;

- Definição do mix de produtos da loja;

- Atividade de compras;

- Uso de sistemas de gestão no restaurante;

- Formação e gerenciamento da equipe do restaurante;

- Gerenciamento financeiro.

Desta forma, tanto a análise como a coleta dos dados deverão abordar este conjunto de tarefas.

\subsubsection{O efeito de complementariedade entre os contratos}

Ménard (2004; 2010) dá grande importância ao mecanismo contratual em seus modelos, enfatizando o caráter relacional dos contratos, como visto anteriormente nos Capítulos 3 e 4. Porém, o autor não indica exatamente um caminho para lidar com uma situação de diversidade contratual num mesmo arranjo.

Conforme a entrevista inicial, de caráter exploratório, realizada junto à Francap, percebeu-se que as cadeias de food service podem apresentar arranjos que envolvem mais de um tipo de contrato. Para lidar com este cenário, resolveu-se adotar uma postura holística, que respeitasse a influência de cada contrato no arranjo, não limitando a análise às transações puramente regidas por contratos de franquia.

Argyres e Liebeskind (1999) discutem o assunto da complementariedade dos contratos apontando uma situação de interdependência gerada pela influência dos mecanismos entre si. O próprio Ménard (2004; 2010), por sua vez, é adepto da ideia de complementariedade entre mecanismos de governança, mas o autor só discute o fenômeno quando este ocorre entre os mecanismos apontados em seus modelos, não entrando no mérito da diversidade contratual num mesmo arranjo. Seguindo a postura sugerida por Argyres e Liebeskind (1999), este trabalho tenta captar a influência da presença de diferentes contratos, compondo um mesmo arranjo. 
Segundo o entrevistado André Friedheim, sócio diretor da Francap, os principais contratos observados nos arranjos de cadeias de food service, são:

- Contrato de licenciamento - CLI

- Contrato de franquia - CFR

- Contrato de máster franquia - CMFR

- Contrato de sociedade (joint venture) - CS

- Contrato de trabalho (vínculo empregatício) - CT

- Contrato de prestação de serviço (operação de varejo) - CPS

- Contrato de fornecimento - $\mathrm{CF}$

- Contrato de locação - CL

- Contrato de venda (spot) - CV

- Cotrato de venda (gerenciado por distribuidor logístico) - CV

Antes de discutir o método de coleta, vale destacar dois controles a serem considerados na análise:

\subsubsection{Estratégia competitiva como variável de controle}

A análise de design organizacional pretendida neste trabalho é basicamente estática, ou seja, como qualquer análise baseada na ECT, é uma análise que não incorpora elementos exógenos à discussão, como por exemplo: decisões estratégicas com horizonte no futuro. Sendo assim, deve-se atentar à limitação da análise para situações em que a escolha mais eficiente (minimizadora de custos de transação) do arranjo híbrido estiver sendo influenciada por eventuais circunstâncias estratégicas, para que não se tire conclusões enviesadas.

Tomando como exemplo hipotético uma grande corporação proprietária de várias empresas, inclusive de uma cadeia de food service e supondo que, em determinado momento, a condição financeira da corporação seja de insolvência, a firma poderia incentivar ao máximo a adoção do sistema de franquia em sua cadeia de food service, para diminuir seu problema financeiro corporativo, mesmo que esse arranjo não fosse o mais eficiente para o negócio. 


\subsubsection{5 $O$ ambiente institucional como variável de controle}

Outra fonte de erro seria comparar empresas imersas em ambientes diferentes. Conforme discutido no Capítulo 6, o ambiente institucional pode ser determinante da escolha híbrida. Sendo assim, a postura neste trabalho é a de comparar empresas que estejam sob a influência do mesmo ambiente institucional.

\subsubsection{Método de coleta}

Para a coleta de informação primária, resolveu-se pela aplicação de uma entrevista em profundidade, semi-estrutrada, com um executivo de contato em cada cadeia do estudo (para mais detalhes, ver COLLIS; HUSSEY, 2005 p. 160).

Como apontado anteriormente na Seção 7.3.2.3, estruturou-se o questionário em torno das atividades compreendidas em todas as funções típicas da administração (Maximiano, 2012). Este recurso foi adotado para garantir uma abordagem completa das possíveis atividades (tarefas) executadas nas empresas em questão.

Para viabilizar a estruturação da discussão em torno das funções de: marketing, produção, finanças e recursos humanos, percebeu-se que seria necessário identificar os principais atores (principais cargos) que atuam nestas empresas, pois as atividades e tarefas estão sempre ligadas a um indivíduo ou grupo (divisão, departamento ou setor) de indivíduos. O conjunto de cargos foi então dividido em: equipe dedicada na máster franquia (e/ou matriz), equipe interna da loja, além de uma seção particular dedicada à atuação do franqueado. Também foram dedicadas seções particulares à: governança da cadeia, à complexidade no ponto de venda e à estratégia competitiva de cada empresa.

O roteiro final foi fruto de três pré-testes. Apesar de ter ficado muito extenso, e conter 
algumas questões que se sobrepõem, optou-se por mantê-lo desta forma para garantir uma varredura completa sobre os temas de interesse no estudo. Os pré-testes foram realizados com a Hamburgeria.

A seguir, será apresentado um resumo esquemático deste roteiro ${ }^{55}$.

\section{PARTE I - ESTRUTURA ORGANIZACIONAL}

1) A equipe de supervisão das lojas

2) A equipe 'dedicada' na máster franquia e na matriz

3) A equipe da loja

4) O sócio operador

PARTE II - GOVERNANÇA

1) Controle e monitoramento

2) Mix contratual (a rede)

\section{PARTE III - TAREFAS (OPERAÇÕES EM ADMINISTRAÇÃO)}

1) Marketing e vendas
a) Sobre o desenvolvimento conceitual do produto
b) Sobre a promoção e propaganda local
c) Sobre a promoção e propaganda coletiva
d) Sobre a expansão
e) Sobre a precificação
f) Sobre a linha de produtos comercializada no $\mathrm{pdv}$

2) Produção
a) Sobre a atividade de compras
b) sobre o desenvolvimento técnico de produtos
c) sobre o uso de sistemas de gestão (software) na loja

3) Recursos Humanos

a) Sobre a formação e gerenciamento da equipe da loja:

4) Finanças

\footnotetext{
${ }^{55} \mathrm{O}$ conteúdo completo das questões está disponível no Anexo II deste trabalho.
} 
PARTE IV - COMPLEXIDADE

1) Preparo técnico x preparo artesanal (Food)

2) Atendimento (Serviço)

a) Extensão

b) Estrutura para consumo

PARTE V - ESTRATÉGIA COMPETITIVA

\subsubsection{Limitações da pesquisa}

Alguns pontos desta proposta de pesquisa devem ser comentados com relação às suas limitações:

\subsubsection{Sobre a utilização do constructo de CPV}

Quanto ao constructo de complexidade no ponto de venda, está claro que sua utilização somente é possível mediante o uso da capacidade de comparação do pesquisador e dos entrevistados.

Para efetivamente usar o constructo como ferramenta capaz de refletir a complexidade no ponto de venda sugere-se uma classificação de três níveis: alto, médio e baixo. Cabe ao pesquisador, com a ajuda dos entrevistados, comparar as cadeias do mercado e encontrar a classificação adequada para cada uma delas. Desta forma, mesmo não havendo uma definição exata do que compõe cada medida, como a avaliação é feita sempre pelo mesmo pesquisador, entende-se que haverá equidade entre as medidas, ou seja, a escala adotada será a mesma para qualquer observação feita pelo pesquisador.

Uma segunda limitação do uso do constructo de CPV é a necessidade de se determinar o peso de cada item a partir das entrevistas, para efetivamente ponderar um resultado final. 


\subsubsection{Mecanismos do Modelo de Ménard (2010)}

O framework adotado para classificar a centralização a partir da adoção dos mecanismos de governança do modelo de Ménard (2010) é uma proposta elaborada pelo autor deste trabalho, devido ao fato do próprio Ménard (2010) não indicar um modelo específico ${ }^{56}$. Não é um framework consolidado na literatura acadêmica.

\subsubsection{Confidencialidade}

Por motivo de confidencialidade não serão revelados os nomes dos executivos das redes de food service entrevistados, nem o das empresas que participaram do estudo de múltiplos casos.

${ }^{56}$ Como também pode ser percebido em seu estudo de caso sobre a indústria de moagem de trigo na França (MÉNARD; REYNAULD, 2010) em que os autores não sugerem um modelo ou framework para análise. 


\section{O CASO HAMBURGERIA}

Um segmento consolidado no setor de food service é o das hamburgerias, não apenas pela presença mundial destes restaurantes, como por ter sido neste segmento que ocorreu pela primeira vez, com sucesso, a organização em sistema de franquias na alimentação fora do lar, em 1955, protagonizada pelo McDonald`s (MCDONALD`S, 2014; LOVE, 1988).

No Brasil, os principais concorrentes neste segmento são restaurantes que não trabalham apenas com hambúrgueres em seu cardápio, mas apresentam um mix de marketing ${ }^{57}$ baseado em lanches que os coloca como concorrentes diretos. Entre as principais marcas ${ }^{58}$, destacamse: McDonald`s, Burger King, Bob`s, Habib`s, Subway e Giraffas. Dentre os concorrentes o McDonald`s, o Burger King e o Subway são cadeias internacionais de origem americana, enquanto Habib`s, Bob`s e Giraffas são empresas brasileiras.

Em relação à linha de produtos: McDonald`s, Bob`s e Burger King têm seus lanches baseados no hambúrguer, sendo que McDonald`s e Bob`s oferecem hambúrgueres chapeados ${ }^{59}$ enquanto Burger King trabalha com o hambúrguer grelhado. O Habib`s também oferece o hambúrguer (chapeado) aos seus clientes, mas sua linha de produtos estende-se também por salgados brasileiros, pizzas e refeições.

O Giraffas, que nasceu como uma típica hamburgeria, atualmente também oferece refeições 'empratadas' ${ }^{60}$ além dos lanches. O Subway difere um pouco dos concorrentes, dado que não trabalha com hambúrgueres, mas oferece uma linha de sanduiches baseada na combinação de pão 'submarino' ${ }^{61}$ com roast beef, aos seus clientes (GUERRA, 2010; GIRAFFAS, 2014).

O público alvo destes restaurantes são as classes A, B e C, sendo que Subway, Giraffas e Habib`s têm um foco maior nas classes B e C, apresentando uma estratégia mais voltada a preço.

\footnotetext{
${ }^{57}$ Mix de Marketing é um termo que reflete a ideia dos 4Ps de Marketing do Modelo de McCarthy (KOTLER; KELLER, 2006).

${ }^{58}$ Este conjunto de empresas foi apontado pelo entrevistado no estudo de caso como concorrentes diretos. Esta nota também fica melhor no próprio texto.

${ }^{59}$ Termo usado no mercado de food service para se referir ao cozimento ou fritura 'na chapa'.

${ }^{60}$ Termo usado no setor de food service para designar restaurantes que oferecem pratos e talheres aos consumidores, durante a experiência de consumo.

${ }^{61} \mathrm{O}$ nome da cadeia foi dado em função deste "estilo" de sanduiche em pão submarino (SUBWAY, 2014).
} 
Quanto à estrutura de atendimento, estas cadeias de restaurantes operam lojas externas (de rua) e lojas em centros comerciais, como shopping centers. O Giraffas tem uma estratégia mais voltada a centros comerciais, principalmente no sudeste. Já o McDonald`s, Bob`s, Burger King e Habib`s atuam tanto em centros comerciais como em ambiente externo, oferecendo muitas vezes o serviço de drive thru a seus clientes.

\subsection{A Hamburgeria}

A Hamburgeria estudada é uma cadeia internacional. Seu design organizacional adotado mundialmente é o de franquia, tendo geralmente $90 \%$ de suas lojas neste formato organizacional e $10 \%$ em integração vertical. Os Estados Unidos é o país com mais restaurantes da rede e apresenta exatamente este mix contratual ${ }^{62}$. No Brasil e na América do Sul, a rede é controlada por uma Máster franquia e apresenta uma característica organizacional diferente do padrão mundial, preservando mais lojas próprias que franquias. No Brasil, a rede tem cerca de 830 lojas, sendo $70 \%$ delas próprias e apenas $30 \%$ franqueadas.

A cadeia tem 62 franqueados no Brasil e a maioria deles é mono operador. Um número pequeno de franqueados opera mais de uma loja, chegando a existir franqueados com até 17 unidades. Os franqueados que têm mais unidades próprias têm suas operações em: Brasília, Salvador, interior do Estado de São Paulo e Fortaleza. Em média, um restaurante brasileiro vende $\mathrm{R} \$ 350$ mil reais por mês e tem cerca de 60 funcionários.

\subsubsection{A unidade de negócios da Hamburgeria: o restaurante}

Para se obter uma visão geral da unidade de negócios da Hamburgeria, será feita nesta seção uma passagem pela linha de produtos e pela estrutura básica (física) de atendimento da loja, de maneira descritiva. A intenção neste ponto é fornecer um primeiro retrato das características peculiares à rede, para seguir aprofundando a discussão nas próximas seções.

\footnotetext{
${ }^{62}$ O termo mix contratual é adotado por Azevedo, Silva, e Silva (2002) para designar a proporção de lojas próprias de uma cadeia.
} 


\subsubsection{A estrutura física de atendimento do restaurante}

Existem dois tipos de loja: as lojas de rua e as lojas de centros comerciais. As lojas de centros comerciais são, principalmente, as lojas de shopping centers. Neste caso, elas podem ser de dois tipos: as lojas que não oferecem acomodação privativa (mesas e cadeiras) aos clientes e aquelas que têm salão próprio. As lojas que não têm salão próprio são geralmente menores e estão sempre localizadas em praças de alimentação, cabendo ao cliente utilizar o salão da própria praça. Essas lojas são denominadas de Lojas Box ou Box em praça de alimentação.

Além dos boxes, também ocorrem lojas maiores em praças de alimentação, com lobby, ou seja, salão próprio. Neste caso, o cliente pode usar tanto o salão do restaurante como o da praça de alimentação. Apesar de terem salão próprio, essas lojas não ocorrem em outros locais dos shopping centers, além das praças de alimentação.

As lojas de rua também são divididas em dois grupos: o de restaurantes com drive thru e o de restaurantes sem drive thru. Existem cerca de 470 lojas de rua no Brasil, contra 360 em shopping centers. As lojas sem drive thru são menores, não oferecem o serviço de drive thru nem o de estacionamento. Essas lojas são chamadas de Lojas de Calçada, ou, Lojas In Store. Dentre as lojas de rua, as In Store ocorrem em menor número, cerca de 100 unidades. As lojas de rua maiores têm estacionamento próprio e passa-carro ${ }^{63}$, oferecendo atendimento drive thru e a comodidade do estacionamento aos seus clientes. São cerca de 370 unidades neste formato. Estas lojas também são chamadas de Lojas Drive.

\subsubsection{A linha de produtos}

A Hamburgeria estudada oferece como principal produto em seu cardápio uma variação de sanduiches baseados no hambúrguer chapeado. Hambúrgueres de carne bovina, frango e peixe, somam-se ao acompanhamento principal, a batata frita, e ao refrigerante, formando o 'carro chefe" do restaurante. Além da linha de sanduiches, o restaurante conta com uma linha

\footnotetext{
${ }^{63}$ Passa-carro é a estrutura pavimentada do drive thru, por onde o carro circula no interior a loja, durante a compra.
} 
de sorvetes para sobremesa e uma cafeteria completa. A hamburgeria não oferece alimentação 'empratada', nem refeições de qualquer tipo que difira de sua linha de sanduiches, exceto os produtos de cafeteria e sua linha de sorvetes.

\subsubsection{A organização da oferta da linha de produtos no restaurante}

A oferta da linha de produtos está organizada conforme a proposta de atendimento aos clientes, formando dois grandes grupos: o de serviço e o de segmentos. O que determina essa organização é a característica de independência operacional de cada grupo. Compreender esta forma peculiar de organização da rede é essencial para o entendimento da dinâmica e fluxo de trabalho em suas unidades.

A área de serviço corresponde ao balcão de atendimento, local onde o cliente interage com o balconista no interior da loja para realizar o pedido, e o salão onde o cliente se acomoda e faz o consumo da refeição, quando este existe.

Quanto aos segmentos, existem quatro deles: os desert centers, as cafeterias, o drive thru e o delivery. O desert center é um balcão ou quiosque separado fisicamente do balcão da área de serviço, que se dedica única e exclusivamente à venda da linha de sorvetes. Estes desert centers podem estar dentro da própria loja (próximos à área de serviço ou na entrada da loja) ou fora dela. No caso das lojas de rua, eles costumam estar fora do salão, na parte externa da loja. Quando estão fora da loja ocorrem como quiosques espalhados pelos shopping centers, o que evidencia a independência deste tipo de operação.

O drive thru também é considerado um segmento separado do atendimento da loja. Ele só ocorre em lojas de rua com passa-carro e pode funcionar independentemente da área de

serviços. É comum Lojas Drive manterem seus serviços de drive thru ativo durante a madrugada, sem que o atendimento no salão esteja funcionando.

O terceiro segmento, a saber, é a cafeteria, que oferece uma linha de cafés, salgados e doces típicos das cafeterias brasileiras. Este segmento geralmente ocorre em uma área reservada no salão de lojas grandes. 
O delivery também é considerado um segmento e, além da estrutura interna de recebimento e operacionalização dos pedidos, conta também com uma estrutura central compartilhada entre as lojas que faz o atendimento ao cliente e, posteriormente, encaminha os pedidos às lojas.

Além das áreas de atendimento, uma unidade tem sempre uma área reservada à preparação dos alimentos, uma 'cozinha', que é chamada de Área de Qualidade. Desta forma, pode-se definir um restaurante da rede pelo conjunto de: uma área de serviço, segmentos e área de qualidade.

Quanto aos segmentos, cada loja irá apresentar uma composição própria, direcionada às características da demanda em sua área de atuação. Para as lojas de shopping, os desert centers são o segmento mais forte, para as lojas de rua o drive thru é o mais significativo e, para toda rede o delivery é o segmento menos significativo.

\subsection{Agentes e atores}

A seguir, serão descritos os principais atores averiguados na cadeia, seguindo a proposta de esquematização colocada no Capítulo 7 de observar separadamente a equipe interna da loja, a equipe dedicada na máster franquia e o franqueado.

\subsubsection{A equipe interna da loja}

A equipe interna da loja segue o seguinte organograma de cargos, conforme ilustra a Figura 17, apresentada na página seguinte: 


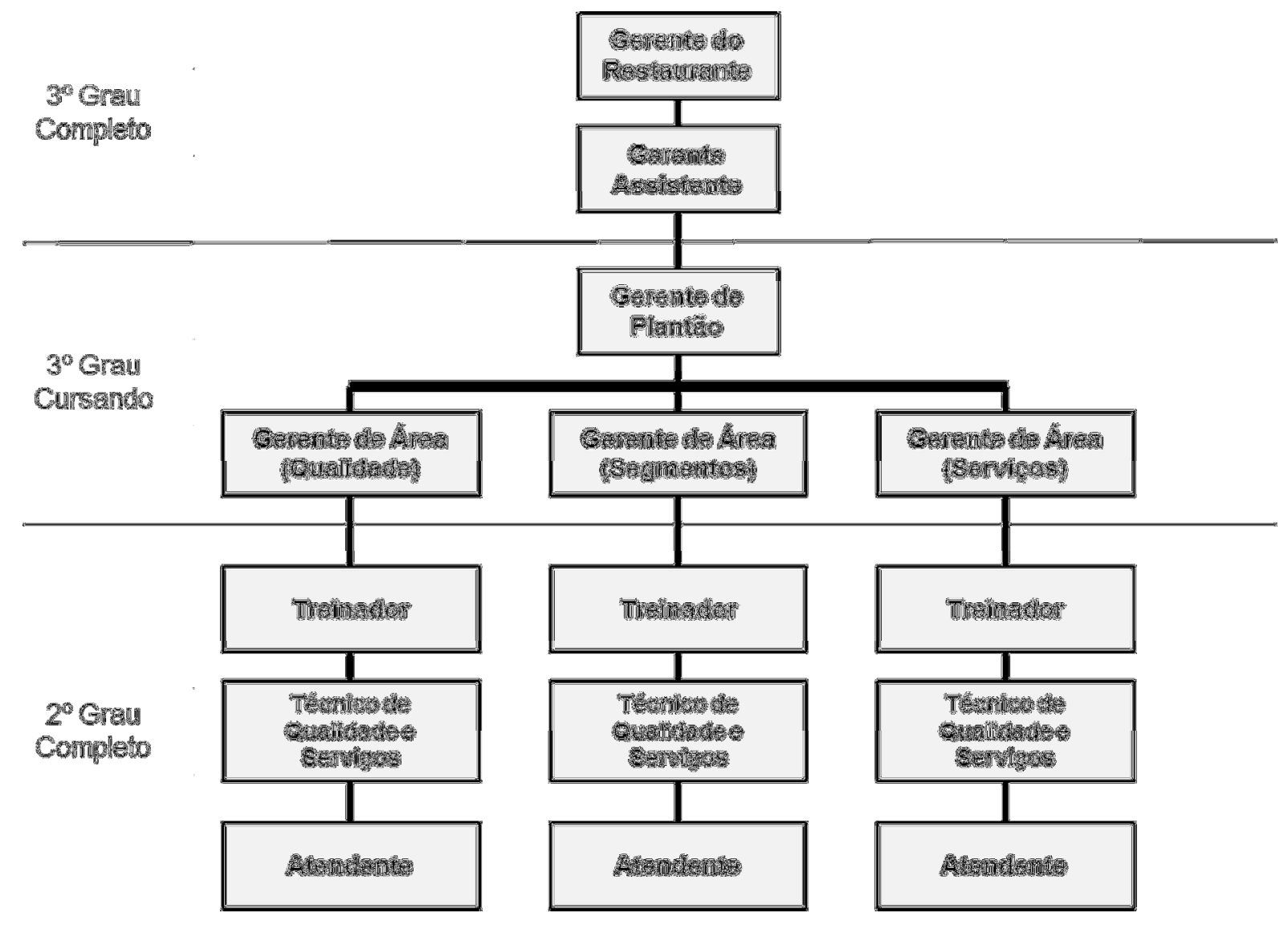

Figura 17 - Organogarama do restaurante (Hamburgeria)

Fonte: elaborado pelo autor, com base nas entrevistas

Todo novo integrante da equipe ingressa no restaurante como atendente. Ele recebe seu treinamento inicial on the job, sob a responsabilidade dos treinadores, até tornar-se técnico de qualidade e serviços. Os treinadores dedicam $80 \%$ de seu tempo à aplicação direta de treinamento para a equipe. $\mathrm{Na}$ fase de treinamento do atendente, o profissional deve passar por 35 estações de trabalho diferentes. Assim que conseguir terminar esta etapa, ele é promovido a técnico de qualidade e serviços, o que leva aproximadamente três meses.

O trabalho de limpeza da loja, atendimento do cliente e preparação dos alimentos é todo realizado pelos atendentes, técnicos de qualidade e serviços e treinadores. Estes profissionais têm geralmente o segundo grau completo.

A supervisão do trabalho é realizada pelo gerente de plantão e pelos gerentes de área (qualidade, segmentos e serviço). Devido à característica do negócio de food service, um restaurante pode operar em diversos momentos do dia, oferecendo café da manhã, almoço, lanches, jantar e até atendimento 24h. No caso da rede estudada, a cadeia chega a oferecer 
todos os tipos de atendimento em algumas lojas, sendo necessário dividir claramente os horários e equipes durante um dia de trabalho, o que reforça a necessidade da figura do gerente de plantão.

Gerentes de plantão e de área devem estar pelo menos cursando o $3^{\circ}$ grau. Gerentes de plantão e de área, assim como atendentes, treinadores e técnicos de qualidade e serviço mantém uma relação celetista horista com o restaurante. A supervisão total da loja é feita pelo gerente do restaurante e pela figura de um gerente assistente, que somente ocorre em casos específicos como o de lojas muito movimentadas. $\mathrm{O}$ gerente do restaurante e o assistente são profissionais que devem ter o $3^{\circ}$ grau completo. Gerentes de restaurante e gerentes assistentes mantêm uma relação celetista sem limite de horas com o restaurante, porque assumem cargos de confiança. O gerente de um restaurante pode se reportar à máster franquia, no caso de integração vertical, ou se reportar à figura do franqueado, no caso de uma loja franqueada.

As próximas duas seções examinam as características da equipe dedicada à rede na matriz e as características específicas do franqueado, respectivamente.

\subsubsection{A equipe dedicada na matriz}

No caso da cadeia estudada, toda a operação da América do Sul é gerenciada por uma máster franquia. A máster franquia se organiza em departamentos para apoiar a cadeia de lojas, como: o de marketing, de operações, de treinamento e de supply chain.

O departamento de operações faz o contato direto entre a máster franquia e os restaurantes. Conforme ilustra a Figura 18, apresentada na página seguinte, para as lojas próprias, na equipe de operações, o consultor de operações é o chefe direto dos gerentes de restaurante. 


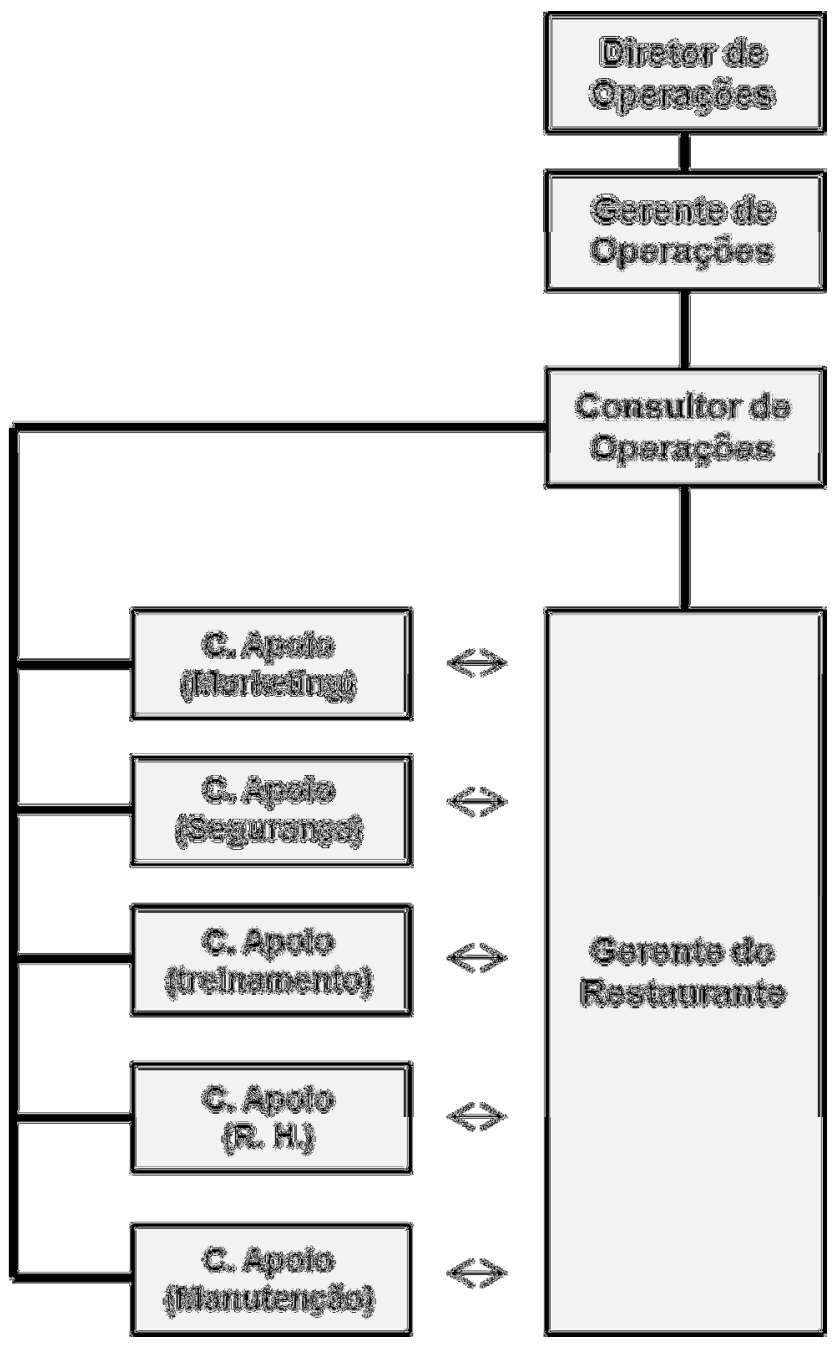

Figura 18 - A equipe de contato da máster franquia (operações)

Fonte: elaborado pelo autor, com base nas entrevistas

O consultor de operações também é responsável por uma série de consultores de apoio que interagem matricialmente com os gerentes de restaurante. Esses consultores facilitam o fluxo específico de informação de cada departamento da máster franquia com as lojas. No Brasil, a equipe de profissionais corporativos alocada especificamente no departamento de operações gira em torno de 140 pessoas.

A seguir, será retratada a relação do restaurante com a máster franquia, quando a loja é franqueada, a partir das atribuições do próprio franqueado. 


\subsubsection{O franqueado}

$\mathrm{O}$ contrato de franquia na rede estudada determina que o franqueado seja integralmente dono de seu restaurante. Ele é denominado internamente como owner operator. Espera-se que o franqueado se dedique exclusivamente ao negócio e seja efetivamente capaz de operar sua loja. Sua dedicação ao negócio implica uma jornada de dez horas diárias. De acordo com o entrevistado, esta expectativa é cumprida à risca na rede, o que a diferencia de muitas outras redes de franquia. O entrevistado comenta que nem sempre foi assim no Brasil e que já houve época em que o conjunto de franqueados não seguia à risca essa determinação, mas, nos últimos 20 anos, esse problema foi equacionado com sucesso.

É comum um parente próximo do franqueado participar da operação da loja, mas nunca, em hipótese alguma, substituir o franqueado. A rede tem, inclusive, uma proposta de sucessão familiar para os restaurantes franqueados em que estimula os filhos dos donos a assumirem o lugar dos pais, em um momento oportuno.

Nas lojas franqueadas, o gerente do restaurante reporta-se ao franqueado, o qual passa a ser o elo da loja com o departamento de operações, diferente da loja própria em que o gerente da loja faz contato direto com o consultor de operações.

Conforme apontado anteriormente na seção 7.1, a maioria das franquias é mono operadora, mas no caso de franqueados que detêm um número maior de lojas é comum a composição de uma equipe de operações própria para apoiar o franqueado.

Apesar de o consultor de operações oferecer exatamente o mesmo apoio às lojas próprias e franqueadas, a intensidade do contato acaba sendo um pouco menor com as lojas franqueadas, devido à agenda mais restrita do franqueado para receber o consultor de operações ou os consultores de apoio.

O franqueado na rede em questão tem duas responsabilidades que lhe tomam a maior parte de seu tempo: a primeira delas é cuidar de todo fluxo financeiro da loja e a segunda é gerenciar a equipe interna da loja, sendo responsável direto pelas contratações. 


\subsection{Atividades, responsabilidades e tarefas}

A seguir, serão descritas as principais tarefas averiguadas na cadeia e sua alocação.

\subsubsection{O desenvolvimento dos produtos}

O desenvolvimento conceitual de novos produtos é capitaneado pelo departamento de marketing da máster franquia. Apesar de alguns produtos consagrados serem fruto do desenvolvimento da matriz global, que remete à história da rede no tempo, o dia a dia de novos desenvolvimentos para a América do Sul sofre pouca influência do exterior. Em um desenvolvimento, além do departamento de marketing, participam as altas gerências de outros departamentos, principalmente de supply chain e de operações. Também participam representante do chamado comitê de marketing, estrutura organizacional formada para captar informações e articular ideias de diversos profissionais da empresa, inclusive de franqueados. Gerentes de restaurante não participam do comitê de marketing.

Apesar de haver uma estrutura (comitê de marketing) capaz de incluir a sugestão dos franqueados, assim como captar insights das lojas próprias trazidos pela equipe de operações, a entrevista deixou claro que a influência real das informações vindas das lojas (próprias e franqueadas) pouco contribui no processo de desenvolvimento de novos produtos.

Dois motivos contribuem para que esta decisão seja tão centralizada: o primeiro é a alocação da decisão ao departamento de marketing com pouco, ou nenhum, investimento em captar insights da periferia da rede. O segundo motivo é o próprio perfil da rede de restaurantes que tem uma linha de produtos muito estável, necessitando estrategicamente de poucos novos desenvolvimentos. O desenvolvimento técnico dos produtos, como: formulação, desenvolvimento processual da montagem dos lanches, adequação dos equipamentos das lojas e aprovação de fornecedores é totalmente centralizado também. 


\subsubsection{O desenvolvimento e veiculação de promoções e propaganda}

O desenvolvimento de promoções e propaganda tem uma dinâmica parecida com a do desenvolvimento de produtos. Da mesma forma, existe uma estrutura organizacional que irá captar os interesses dos franqueados: os chamados comitês de marketing. No caso das lojas próprias, as informações pode fluir pela estrutura do departamento de operações.

Novamente, apesar de existir a possibilidade de captar insights da periferia da rede, na prática, a decisão é centralizada. As informações sobre as características da demanda e como os consumidores avaliam os produtos da rede são obtidas pela encomenda de pesquisas de opinião. O Departamento de Marketing produz o material de promoção e propaganda utilizando o apoio de agências de publicidade.

Devido às características do negócio de fast food, a empresa foca sua estratégia de propaganda em campanhas promocionais que gerem fluxo de clientes nas lojas e campanhas institucionais que protejam e enalteçam a marca da rede. As campanhas institucionais também são desenvolvidas e veiculadas de maneira centralizada.

Todas as lojas da rede devem aderir às campanhas promocionais. A diferença na adesão das lojas ocorre em relação às ferramentas locais de promoção, que são desenvolvidas pelo departamento de marketing, podendo ser adequadas às especificidades da demanda de cada loja. Não há contribuição das lojas no desenvolvimento dessas ferramentas, nem no desenvolvimento de alguma ferramenta especial. O que pode ocorrer é a escolha de mix promocional específico para ações num determinado ponto de venda.

Tanto em lojas próprias como em lojas franqueadas, os consultores de apoio e o departamento de marketing podem ajudar um ponto de venda especifico a escolher um conjunto de ferramentas promocionais (como: cuponagem, panfletagem e ações conjuntas com outros varejistas), que esteja mais alinhado às características de seu ponto de venda.

Com relação à promoção no ponto de venda, surge uma das poucas diferenças entre a tomada de decisão nas lojas próprias e a tomada de decisão nas unidades franqueadas: o franqueado pode influenciar na escolha de seu mix de promoção, assumir investimentos no processo e até 
mesmo articular ações conjuntas com outros varejistas pessoalmente. No entanto, o departamento de marketing sempre deverá aprovar qualquer ação escolhida pelo franqueado.

\subsubsection{A expansão da rede e a escolha do ponto comercial}

A questão de expansão da rede e escolha do ponto comercial deve ser vista com cuidado, pois sua realidade, atualmente, é um pouco diferente do ocorrido inicialmente quando a rede instalou-se no Brasil.

A prospecção de pontos de venda e avaliação da adequação desses pontos para os negócios da rede é totalmente centralizada, sendo feita por profissionais que atuam de forma parecida com corretores de imóveis, sendo chamados de Representantes de Imóveis, ou 'Reps'! Estes profissionais fazem parte da equipe de operações da Máster Franquia.

Quando um ponto é identificado e a rede decide montar uma nova loja, a oportunidade poderá ser oferecida à rede de franqueados caso a estratégia de Mix Contratual esteja favorável a mais uma loja franqueada. Caso contrário, a loja será própria. Em ambos os casos, a Máster Franquia é quem negocia a aquisição do ponto junto ao proprietário do imóvel e também é o agente que arremata o ponto. Depois de arrematá-lo, a Máster Franquia poderá abrir mais uma loja própria ou locar o ponto para um franqueado. No processo de expansão por franquia, sempre será dada prioridade aos atuais franqueados para que estes assumam uma nova loja da rede, contra a ideia de se abrir a oportunidade para um novo franqueado.

A escolha do ponto é uma decisão de peso no varejo e, conforme explicado até aqui, é centralizada no caso estudado. Deve-se salientar que, durante a implantação da rede, ocorreram casos em que os franqueados participaram dessa tomada de decisão. Alguns franqueados eram os próprios donos de certos pontos comerciais e vieram diretamente à rede oferecer a oportunidade de negócio. Em outros casos, alguns franqueados com perfil empreendedor foram capazes de identificar certos pontos com grande potencial e trazer essa informação à rede. Na maioria das vezes, esse tipo de situação ocorria no interior, onde o conhecimento específico do local é mais difícil de ser adquirido pela empresa do que pelo franqueado local. 
Apesar dos casos citados anteriormente sobre a participação de franqueados nessa tomada de decisão, o entrevistado deixou claro que a dinâmica atual da expansão é totalmente centralizada e dá prioridade ao crescimento dos franqueados que integram a rede, em vez de estimular o crescimento do número de franqueados.

\subsubsection{Precificação}

A precificação também é uma decisão centralizada na Máster Franquia. As lojas próprias não têm qualquer influência na tomada desta decisão, recebendo uma tabela de preços estipulada pela Máster Franquia, de acordo com sua visão da demanda potencial do ponto venda e da necessidade de margem operacional para cada item vendido.

As lojas franqueadas recebem um pouco mais de direitos de decisão no que tange a essa questão. Elas podem usar uma banda de preço que tem uma variação de mais ou menos $10 \%$ em relação ao preço estabelecido pela Máster Franquia. Esta é a única margem de manobra do franqueado, que não pode mudar o 'tabelamento' imposto pela Máster Franquia além desse desvio previamente acordado.

\subsubsection{Definição do mix de produtos da loja}

Esta é mais uma decisão bastante centralizada na rede. A escolha de quais itens serão ofertados e quais segmentos serão instalados em cada loja é uma decisão centralizada e concentrada no departamento de operações. As lojas próprias não influenciam essa decisão, que é tomada antes mesmo da equipe da loja ser designada. Na loja franqueada, ocorre a participação do franqueado na decisão, que deverá aprovar sua sugestão com a Máster Franquia, ou seja, a palavra final será sempre a da Máster Franquia. O entrevistado chegou a afirmar categoricamente que a participação do franqueado nesta decisão é pouco significativa. Seria esperado que um franqueado com loja em centro comercial, com perfil empreendedor, fosse capaz de influenciar essa decisão, caso ele pudesse negociar junto à administração do Shopping Center a possibilidade de instalar desert centers em alguns corredores 
movimentados do shopping. Mas, no caso específico da cadeia estudada, conforme discutido na seção 7.7, a negociação com o locatário é feita pela Máster Franquia, reforçando a forte centralização apontada pelo entrevistado.

\subsubsection{Atividade de compras}

As compras são uma atividade importante e intensa em trabalho humano para o setor de food service. O fluxo diário de recebimento de ingredientes caracteriza definitivamente o trabalho com alimentação. Na cadeia estudada, as compras são centralizadas e cabe ao Departamento de Supply Chain operacionalizar essa atividade.

A Hamburgeria vem investindo no desenvolvimento de uma relação estreita com seus fornecedores desde o inicio de sua história. Este amadurecimento trouxe para os dias de hoje a contratação de uma empresa de logística para auxiliar o abastecimento da rede.

O processo de compras tem início com a aprovação qualitativa de um fornecedor e a negociação de preços. Esta fase é gerida pelo Supply Chain da Máster Franquia. Em seguida, o Parceiro Logístico da cadeia irá se responsabilizar por operacionalizar as entregas dos insumos nas lojas. A cadeia conta com um armazém central, onde concentra seu estoque de itens comprados e onde alguns fornecedores (de pães e cárneos) instalaram suas fábricas para estar em sintonia com o processo de logística da Hamburgeria. Cumpre observar que dificuldades de abastecimento decorrentes de sazonalidade não são significativas na cadeia de suprimento da rede.

A Hamburgeria não fornece qualquer insumo à rede, nem é dona de fábricas de alimento que atuam como fornecedores da rede. Além de negociar e aprovar a compra de insumos para a fabricação das refeições, o mesmo processo é feito em relação à compra das embalagens descartáveis que são usadas para a comercialização dos lanches.

A necessidade de compra de cada loja é informada ao Parceiro Logístico pelos gerentes de restaurante. Mesmo em lojas franqueadas, a função de apresentar pedidos de compra é do gerente e não do franqueado. Deve-se observar que a apresentação desses pedidos não implica 
uma tomada de decisão pelo gerente, pois o que ele está fazendo nada mais é que informando sua necessidade de insumos para alcançar o volume padrão de estoque que ele deve manter em sua loja, conforme lhe foi ensinado em seu treinamento, confirmando uma total centralização desta decisão.

É claro que a atuação de um Parceiro Logístico implica descentralizar parte dos direitos de propriedade, mas o que importa no caso deste trabalho é verificar que o direito de decisão descentralizado não migrou da Máster Franquia para a rede de lojas!

\subsubsection{Uso de sistemas de gestão no restaurante}

Sistemas de gestão são usados nos restaurantes, principalmente para controlar estoques, o ponto de funcionários e a produção das refeições. Existe um comitê de informática que atua nesta área, que conta com a participação de franqueados também. Na prática o comitê auxilia mais em questões de implantação do que na escolha propriamente dita de qual sistema deverá ser adotado ou de qual deverá ser a abrangência da atuação do sistema sobre a operação do restaurante. Novamente a centralização é observada.

\subsubsection{Formação e gerenciamento da equipe do restaurante}

O primeiro passo para o estabelecimento de uma equipe para um restaurante é a contratação. A Máster Franquia atua diretamente na contratação da equipe de suas lojas próprias e oferece aos franqueados o mesmo recurso oferecido às suas lojas próprias para tanto.

Os gerentes das lojas ainda são responsáveis pela captação de $50 \%$ a $60 \%$ dos candidatos que ingressam na rede, recebendo currículos de interessados (captação) e enviando ao Departamento de Recursos Humanos para serem avaliados e, se aprovados, poderem ser contratados. Desta forma, a aprovação é feita pelo Departamento de Recursos Humanos, com a participação do gerente do restaurante. Basicamente, o gerente conduz um processo, cujos contornos são efetivamente desenhados (decididos) de maneira centralizada, pelo 
Departamento de Recursos Humanos. Um Gerente Selecionador, que faz parte da equipe do Departamento de Recursos Humanos, atua nas lojas dando suporte para otimizar o processo de contratação de funcionários. Outra forma de atuação da Máster Franquia é mantendo uma Central de Seleção no centro da cidade, montada especificamente para captar novos funcionários, que são direcionados aos restaurantes.

Apesar de a Máster Franquia oferecer solução de contratação para seus franqueados, a formação das equipes segue um caminho diferente nas franquias. Conforme visto na Seção 7.4, o franqueado se dedica intensamente à captação e gerenciamento de seus funcionários. Ele tem o direito de escolher seus próprios funcionários sem aprovação da Máster Franquia, apenas se comprometendo a respeitar sempre as leis trabalhistas vigentes no relacionamento com sua equipe.

Um franqueado é capaz de avaliar e contratar um funcionário novo em três dias, se for necessário. Já a Máster Franquia faz isso de forma bem mais demorada levando em média 60 dias para fechar uma contratação. Além da agilidade maior do franqueado na contratação, ao participar deste processo o franqueado traz o conhecimento específico da sua loja à discussão, sendo mais eficiente a escolha do perfil do funcionário à sua loja do que seria uma central de recrutamento que tem menos capacidade de perceber qualquer diferença de nuance entre as lojas e suas necessidades particulares.

O perfil empreendedor do franqueado também pode fazer diferença quando comparamos lojas próprias e franqueadas. A capacidade individual do franqueado, se ele for um indivíduo empreendedor, e dedicar-se pessoalmente ao processo de captação e gerenciamento de sua equipe, pode gerar resultados superiores aos da central de recrutamento.

Após a contratação, o treinamento é fundamental para garantir a integração do funcionário às rotinas do restaurante. Os treinamentos são todos desenvolvidos e formatados pela Matriz e pela Máster Franquia, e são considerados um dos maiores patrimônios da empresa, e razão de seu sucesso. Na Máster Franquia o Departamento de Treinamento dedica-se a desenvolver e promover treinamento e difusão de conhecimento e rotinas pela rede.

Além do desenvolvimento das rotinas de treinamento é necessário aplicar o treinamento, ou seja, fazer com que o treinamento efetivamente ocorra e não seja apenas uma lista de ideias 
escritas num manual de instrução. Duas figuras são primordiais no sucesso dos treinamentos na loja: o franqueado (ou o gerente da loja própria) e os treinadores. O franqueado atua criando condições, apoiando, estimulando e controlando a aplicação dos treinamentos. Na loja própria, a figura do gerente do restaurante assume essa responsabilidade. A parte operacional do treinamento é aplicada pelos treinadores, que dedicam pelo menos $80 \%$ de seu tempo a isso, usando sempre a técnica de treinamento on the job.

Conforme visto na Seção 7.4, o gerenciamento da equipe, detalhado na seção atual, é uma das duas atividades principais do franqueado. A segunda atividade é o gerenciamento financeiro da loja, que será o tema da próxima seção.

\subsubsection{Gerenciamento financeiro}

Gerir o fluxo de caixa de um restaurante é uma atividade intensa. São muitos itens sendo vendidos e comprados, além de muitos funcionários sendo pagos, admitidos e demitidos. Especialmente no caso da Hamburgeria estudada, o gerenciamento do fluxo de caixa deve ser muito bem feito, dado que a margem de lucro da operação é baixa e qualquer eventual perda pode influenciar fortemente o resultado final.

O gerenciamento financeiro refere-se à atividade contábil de gerenciar o fluxo de caixa da loja, e não implica em outras atividades descritas anteriormente como: negociar preços com fornecedores, determinar (precificar) o preço final no ponto de venda ou efetuar compras.

Na loja franqueada, a responsabilidade de gerenciar o fluxo de caixa do restaurante é do franqueado, que efetivamente gasta seu tempo realizando essa atividade. É comum o franqueado ser casado e contar com a ajuda de seu cônjuge na operação da loja, ocorrendo deste cônjuge, pessoa de confiança do franqueado, assumir parte desse dever. 


\subsubsection{Alocação dos direitos de decisão: quadro geral}

A Figura 19, apresentada a seguir, ilustra a alocação típica de direitos de propriedade da Hamburgeria estudada. No caso, um arranjo altamente centralizado.

\section{Master Franquia}

Franquia

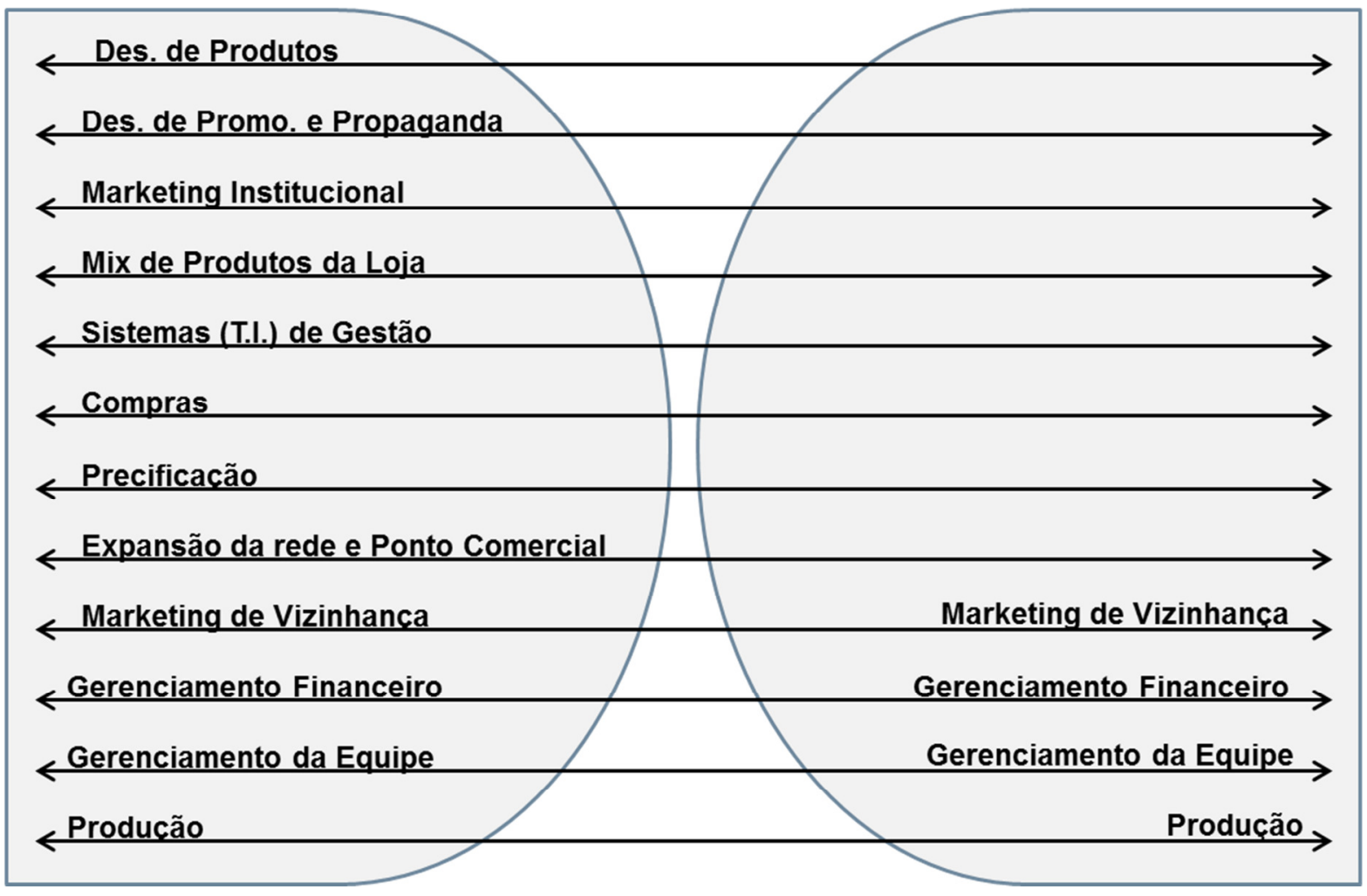

Figura 19 - Alocação dos direitos de decisão na Hamburgeria (quadro geral)

Fonte: Elaborado pelo autor com base nas entrevistas

\subsection{Complexidade}

Durante a discussão da Metodologia no Capítulo 7, foi colocado que a complexidade no ponto de venda tem um caráter fabril (manipulação) e um caráter de serviços (atendimento). O caráter fabril é determinado pelo número de etapas do processo produtivo, pela intensidade tecnológica adotada, pela aderência ao uso de rotinas, pelo volume de produção e qualidade dos alimentos produzidos e pelo tamanho da equipe envolvida neste processo. O caráter de 
serviços do constructo é determinado pela extensão do atendimento, pela estrutura deste atendimento, pelo volume de clientes atendidos no restaurante a certo nível de atenção (qualidade do atendimento) e pelo tamanho da equipe envolvida nessa atividade.

\subsubsection{Etapas no processo produtivo}

O número de etapas do processo produtivo é médio. Como em qualquer lanchonete, há necessidade de fritar os hambúrgueres, cortar pões e vegetais, adicionar molhos etc. O processo assemelha-se a uma linha de montagem! Apesar de tratar-se apenas de sanduiches, há necessidade de porcionamento ${ }^{64}$ e aplicação de tratamentos térmicos (como a fritura), o que indica um número médio de etapas no processo produtivo.

\subsubsection{A intensidade técnica do preparo}

Conforme visto no início deste estudo de caso, a área designada ao preparo é denominada de Área de Qualidade, ou seja, a cozinha do restaurante.

Os itens produtivos, aqueles que entram na formulação das refeições, variam em torno de 100 tipos, sendo a maioria dos itens industrializados, chegando à loja prontos ou semi-prontos. Eles podem ser divididos em: cargas secas (40\%), cargas congeladas (30\%) e cargas resfriadas $(30 \%)$.

As cargas secas são itens como: catch up, molhos, óleo para fritura, xaropes para máquinas de refrigerante etc. Cargas congeladas incluem o hambúrguer (pronto para ser frito), a batata descascada em palitos (pronta para ser frita) etc. As cargas resfriadas incluem itens in natura como vegetais e pães já forneados ${ }^{65}$.

\footnotetext{
${ }^{64}$ Termo técnico usado no setor de food service para se referir ao processo de fracionamento do alimento.

${ }^{65}$ Termo técnico usado no setor de food service para se referir ao processo de cocção em forno.
} 
Todos os utensílios de cozinha usados são tecnificados, muitos deles foram desenvolvidos pela própria matriz ou em parcerias da matriz com fornecedores. O preparo, cuja principal atividade é a fritura do hambúrguer e montagem do sanduiche (incluindo a condimentação), segue procedimentos típicos de uma linha de montagem industrial.

A tecnificação é uma característica comum no segmento estudado. O entrevistado fez questão de frisar que acharia improvável que qualquer concorrente direto da Hamburgeria pudesse usar um nível de tecnificação mais simples do que o seu.

\subsubsection{Rotinas}

O preparo é altamente formatado em relação às rotinas. As rotinas foram intensamente formatadas na matriz e na Máster Franquia. Elas constam do manual do franqueado e estão disponíveis em formato impresso às lojas próprias também.

Todo o preparo é padronizado, não existindo qualquer procedimento fabril que não tenha sido descrito e roteirizado previamente. A montagem do sanduiche deve seguir certa ordem, o hambúrguer deve ser frito numa dada temperatura e por um tempo certo, e os ingredientes devem ser adicionados formando o mesmo lay out sempre. O resultado dessa padronização é um produto final com pouquíssima variação de atributos de qualidade, para que o cliente não perceba qualquer variação entre os restaurantes da rede.

Esta característica de utilização intensa de rotinas explica a necessidade e importância dada pela empresa ao treinamento dos funcionários. Das 35 estações de treinamento percorridas pelo atendente em seu percurso para tornar-se um técnico de qualidade e serviço ${ }^{66}, 45 \%$ delas são estações dedicadas ao preparo dos alimentos.

Rapidez é um atributo que exige o uso de utensílios tecnificados, mas depende mais ainda do desenvolvimento de rotinas específicas de preparo.

\footnotetext{
${ }^{66}$ Conforme descrito na Seção 7.3.1.
} 


\subsubsection{Volume da produção}

Devido à proposta de valor ofertada ao cliente incluir fortemente o atributo de rapidez, a agilidade da linha de produção dos lanches é enorme, caracterizando profundamente o processo fabril do restaurante. No caso do preparo de um sanduiche, espera-se que isso ocorra em um prazo de 35 a 50 segundos.

O tempo de preparo de todo um pedido não deve ultrapassar 210 segundos e o tempo total gasto por um cliente desde que entra na fila para ser atendido e o momento em que recebe sua bandeja com a refeição não deverá ser maior que 310 segundo. Tudo faz parte da proposta: made for you, adotada pela empresa, em que os lanches são confeccionados somente mediante o pedido do cliente, não havendo preparo antecipado de sanduiches como fazem algumas cadeias de fast food.

A rapidez no atendimento está alinhada à estratégia de marketing da empresa de trabalhar com um produto de margem baixa e alto giro, exigindo um volume de vendas grande, consequentemente, também um elevado volume de produção. Um alto executivo do setor, concorrente desta Hamburgeria, chegou a afirmar ${ }^{67}$ que o subgrupo das Hamburgerias fast food caracteriza-se por ter um dos maiores volumes de produção por restaurante, no setor de food service.

\subsubsection{Nível do produto}

A sofisticação do prato é baixa e a embalagem do lanche é descartável. Um contraponto a esta proposta é dado pela rapidez do atendimento, padronização dos produtos e frescor dos lanches (made for you).

\footnotetext{
${ }^{67}$ Esta informação foi colhida em um contato direto com este executivo, que não chegou a se caracterizar como uma entrevista completa. O contato foi feito no primeiro semestre de 2014.
} 


\subsubsection{Equipe de produção}

Uma das características do preparo é a intensidade de uso de mão de obra. Para a Hamburgeria em foco, esta intensidade é grande. Pode-se dizer que uma loja simples, ou seja, sem segmentos, deve ter aproximadamente $50 \%$ de sua equipe alocada na área de qualidade. Para compreender esta dinâmica, deve-se observar que, quanto mais segmentos, menor será a porcentagem da equipe alocada na Área de Qualidade, pois os segmentos são todos classificados como atividade de atendimento (serviço).

Conforme observado no início deste capítulo, na Seção 8.1, uma loja típica da Hamburgeria no Brasil tem, em média, 60 funcionários. Assim, pode-se estimar que o número médio da equipe responsável pela produção dos alimentos seja de $30^{68}$ funcionários. No caso específico da Hamburgeria, estima-se que o restaurante trabalhe, em média, com 2,5 turnos, devido ao grande número de restaurantes com Drive aberto de madrugada. Desta forma, uma cozinha típica deve ser operada por, no mínimo, 12 funcionários dedicados à manipulação dos alimentos.

\subsubsection{A extensão do atendimento}

A extensão do atendimento é média.

O que caracteriza o fast food é a rapidez no atendimento, o pagamento antecipado e o momento do consumo ser desprovido de contato direto do cliente com os funcionários do restaurante. Mesmo não havendo contato com funcionários o consumo é feito in loco, o que leva a uma caracterização de média extensão do atendimento.

\footnotetext{
${ }^{68}$ Provavelmente o número o número médio da equipe responsável pela produção dos alimentos não é este. Um motivo seria que a maioria das lojas têm segmentos, sendo necessário usar uma estimativa menor que $50 \%$ para compor a Equipe da Área de Qualidade. Outro motivo é que algumas atividades que envolvem manipulação, como o preparo das batatas fritas e dos sorvetes, não são classificados como atividades da Área de Qualidade e não estão sendo contabilizados neste cálculo. Como o número exato não interfere na discussão proposta neste trabalho, pois o que importa é o número total de funcionários (a soma entre os funcionários da área de preparo e atendimento), será mantida a estimativa de uma equipe media de 30 pessoas ligadas à atividade de produção.
} 


\subsubsection{A estrutura de atendimento}

A estrutura é bastante significativa no resultado final do serviço oferecido aos clientes da Hamburgeria.

Conforme descrito no início deste capítulo, na Seção 8.1.2, de acordo com as características da estrutura de atendimento, as lojas da Hamburgeria dividem-se em Lojas tipo Box em Praça de Alimentação, Lojas com Lobby em Praça de Alimentação, Lojas de Rua In Store e Lojas de Rua Drive.

Uma observação deve ser feita ao comparar a estrutura de atendimento de uma loja de shopping e uma loja de rua: essa comparação tem suas limitações! Na prática, uma loja incrustrada em um centro comercial, como um shopping center, oferece inúmeras comodidades que um restaurante de rua, mesmo que seja uma Mega Store, não consegue oferecer, pois a loja de shopping oferece a proximidade de um centro de lazer e compras, o que não ocorre com as lojas de rua. Ao comparar suas estruturas, deve-se limitar a comparação às estruturas internas, não comparando, por exemplo, o Play Ground de uma loja de rua com um Play Ground disponível em um shopping onde há um restaurante da Hamburgeria.

Sob a ótica operacional, o impacto da existência da estrutura de atendimento em uma loja é muito grande. Cada item oferecido ao cliente requer cuidados por parte do lojista. Quanto maior a estrutura oferecida, mais horas de limpeza e manutenção deverão ser investidas. Quanto mais diversa for a estrutura, mais conhecimento específico a unidade deverá ter para gerir a operação.

A principal diferença operacional surge na comparação de uma loja de rua com uma loja de shopping. No caso da loja de rua, o lojista tem que se preocupar com inúmeros itens e situações que não ocorrem às lojas de shopping, como:

- Estacionamento (limpeza, sinalização, acesso/cancela, gerenciamento de eventuais acidentes automotivos, iluminação); 
- Pista Drive $e^{69}$ (iluminação, sinalização e limpeza);

- Segurança patrimonial do cliente, da equipe e da loja (gerenciamento de situações de: assalto à loja, roubo de pessoas no interior da loja, roubo no estacionamento e roubo de carros);

- Energia elétrica (fornecimento, gerenciamento de situações de apagão);

- Escoamento do lixo (gerenciamento de horários de coleta, estrutura de armazenamento, estrutura para coleta simples e seletiva, gerenciamento/contenção de mau cheiro);

- Caixas de Água (estrutura, gerenciamento do abastecimento, limpeza);

- Banheiros (limpeza, abastecimento de utensílios, manutenção);

- Gerenciamento de situações de caos urbano que fazem com que a loja tenha que ser fechada às pressas (alagamentos, conflitos urbanos);

- Área externa (limpeza e manutenção do entorno, inclusive dos jardins);

- Vizinhança (interação com vizinhos, pedestres e eventuais pedintes, manutenção da calçada);

- Play Ground (limpeza, manutenção de equipamentos, gerenciamento de segurança infantil na interação com o parquinho).

A loja com a estrutura mais completa na rede é a Loja Drive ${ }^{70}$. Essa afirmação leva em conta que qualquer loja Drive é automaticamente uma loja de rua, o que implica toda gama de tarefas recém descritas, e, segundo o entrevistado, o Drive é o segmento que causa maior impacto em 'horas não produtivas, ${ }^{, 71}$.

A Loja Drive oferece uma estrutura de atendimento com salão próprio para o cliente consumir sua refeição, banheiros privativos, estacionamento e drive thru. Lojas Drive são geralmente grandes e acomodam desert centers, cafeteria, salão para festas infantis e até um Play Ground. No caso de delivery, apesar deste segmento ser pouco explorado na rede, quando ele ocorre é geralmente encontrado nas lojas Drive.

\footnotetext{
${ }^{69}$ Pista Drive é um termo usado no setor de food service para referir-se ao passa-carro.

${ }^{70}$ Loja que oferece o serviço de drive thru.

${ }^{71}$ Horas não produtivas são as horas gastas com a qualquer atividade que não seja ligada diretamente ao atendimento do cliente e produção dos lanches, ou seja, horas reservadas à manutenção e limpeza da loja principalmente.
} 
O Drive Thru deve ser entendido como o conjunto entre a estrutura de atendimento (a cabine) e a pista drive (passa carro). Na prática, a pista está sempre ligada à existência do estacionamento, sendo que o padrão acaba sendo a ocorrência de ambos concomitantemente. Desta forma, um dos motivos do segmento exigir tantos cuidados advém da necessidade de cumprir as tarefas ligadas ao estacionamento e à pista drive.

A grande maioria dos Drive Thrus fica aberto 24 horas, mesmo que a loja encerre seu atendimento após as 23:00hs ${ }^{72}$. Tal horário de funcionamento implica um turno de empregados específico para manter o drive aberto, que, além de ser contratado para dedicação exclusiva ao drive, atua de madrugada, acumulando mais encargos trabalhistas que os outros turnos, impondo à gerência uma nova gama de tarefas para supervisionar esta nova equipe num horário extra.

Uma Loja In Store difere da Loja Drive pela ausência de estacionamento, passa carro e atendimento drive thru. Sendo assim, caracterizam-se pelo acúmulo de todas as outras tarefas de uma loja de rua que não estão ligadas ao drive e ao estacionamento.

Lojas In Store ocorrem geralmente em pontos comerciais onde o volume de pedestres que circulam no entorno é muito grande como, por exemplo, o centro da cidade de São Paulo. O atendimento nestes locais dispensa o drive, porque, na prática, o tipo de imóvel não permite acomodar um estacionamento, ou, às vezes, não há circulação de automóveis no local, como é o caso do centro de São Paulo. Em alguns casos o preço do aluguel do imóvel por metro quadrado é tão elevado que não vale a pena implantar o drive.

As lojas de Shopping carregam muito menos tarefas e 'horas não produtivas‘ que as lojas de rua. As lojas maiores têm salão próprio privativo (lobby) para que o cliente possa fazer sua refeição de maneira mais confortável, ou seja, em ambiente exclusivo. Podem ter outros segmentos como desert centers e cafeteria também.

O que caracteriza a estrutura de atendimento de um Box em Praça de Alimentação é a ausência de área privativa, o que denota menos serviço oferecido ao cliente do que uma loja com lobby e menos custo em 'horas não produtivas'.

\footnotetext{
${ }^{72} \mathrm{O}$ nome dado ao regime de atendimento exclusivo no drive durante a madrugada é: horário estendido.
} 


\subsubsection{Volume do atendimento}

O volume de clientes atendidos num mesmo restaurante da Hamburgeria é muito grande, conforme explicado na Seção 8.4.4.

\subsubsection{Nível do atendimento}

O atendimento é levado num nível intermediário.

Os funcionários que interagem com os clientes são treinados para ser cordiais e educados, sem ir além no relacionamento com os clientes. Além de ser uma interação simples, o atendimento é muito rápido, permitindo pouco contato do balconista com o cliente. A equipe de contato não oferece qualquer apoio ou tratamento personalizado aos frequentadores do restaurante.

\subsubsection{A equipe de atendimento}

A equipe destinada ao atendimento é grande. Seguindo a mesma lógica da discussão sobre o número de indivíduos ligados à produção recém-discutida (Seção 8.4.4), estima-se uma equipe total de 30 funcionários dedicados por restaurante ao atendimento, ou seja, algo em torno de 12 pessoas na equipe por turno de trabalho.

\subsubsection{Complexidade: quadro geral}

A seguir, conforme ilustra a Figura 20, será retomado o quadro completo do constructo de complexidade no ponto de venda, com o intuito de incluir na figura as informações observadas sobre o caso específico da Hamburgeria estudada. 
Deve-se ressaltar que as entrevistas revelaram que entre todos os itens que formam o constructo, o entrevistado indicou o número total da equipe como sendo o de maior impacto sobre a complexidade no ponto de venda. Quanto aos outros itens, não houve indicação que pudesse levar a uma ponderação de seus impactos.

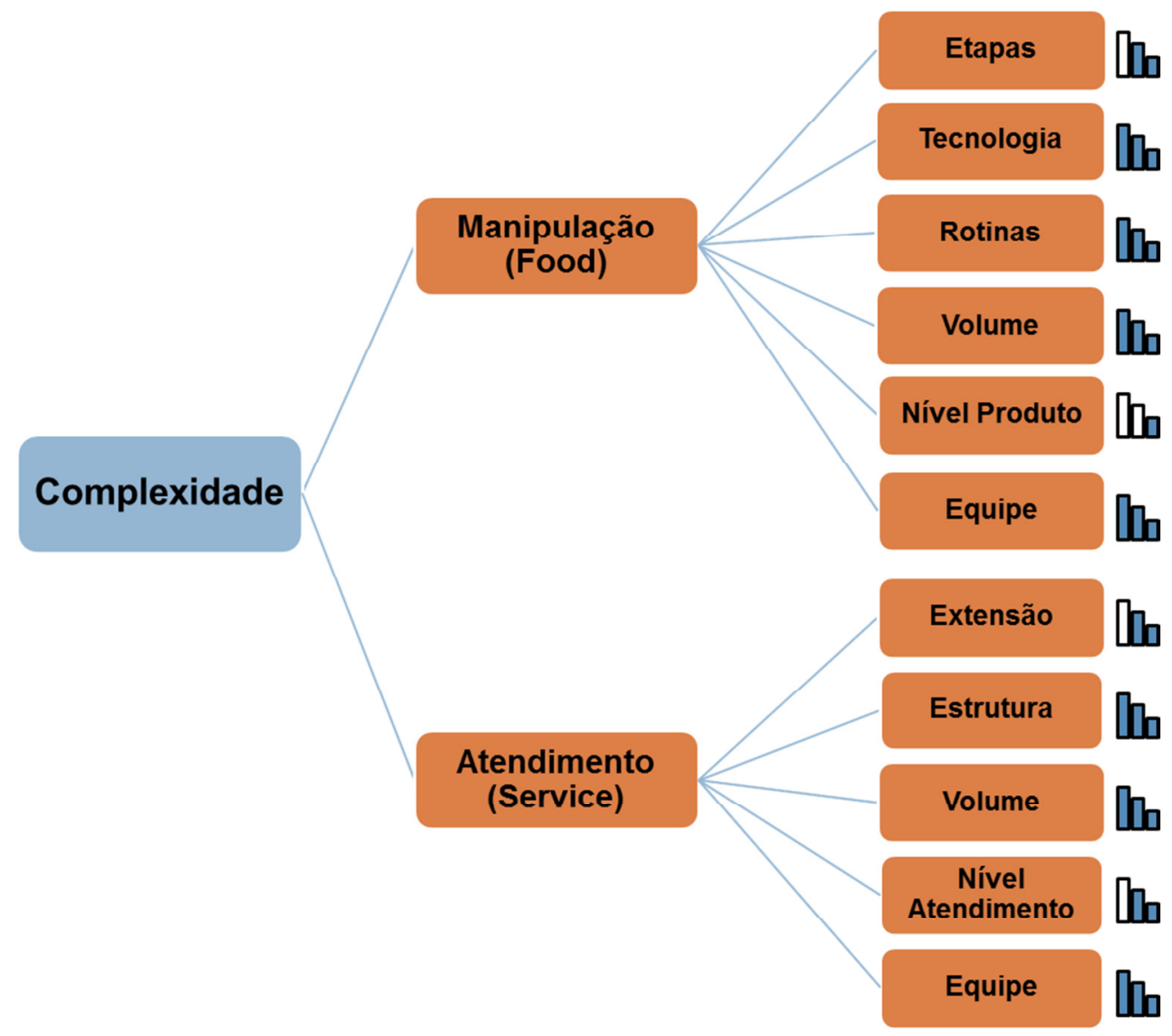

Figura 20 - A complexidade no ponto de venda da Hamburgeria

Fonte: elaborado pelo autor, com base nas entrevistas

\subsection{A governança da relação entre a Máster Franquia e seus restaurantes}

Utilizando o modelo de Ménard (2010) como estrutura de análise da governança na relação entre uma máster franquia e seus restaurantes, será apresentada a seguir uma discussão sobre como cada um dos mecanismos apontados pelo autor ocorre na hamburgeria do caso estudado, detalhando a relação máster franquia \& lojas próprias e máster franquia \& lojas franqueadas. 


\subsubsection{O contrato de franquia ${ }^{73}$}

O contrato de franquia da Hamburgeria é um contrato bastante completo. Sua intenção é deixar poucas possibilidades de renegociação para o futuro. Existe um esforço em tentar prever possíveis conflitos e deixar trilhado um caminho ex-ante para uma solução.

Entre os itens do contrato, pode-se destacar um extenso detalhamento de obrigações que o franqueado deverá assumir para não comprometer, ou, usando a terminologia do próprio entrevistado: 'arranhar", a marca da rede. Estas obrigações incluem o compromisso de pagamento de royalties e taxa de propaganda, e de adesão ao sistema da rede. O compromisso contratual também exclui o direito de alienação independente da franquia pelo franqueado.

A adesão ao sistema da rede é intensamente detalhada no manual do franqueado, sendo, na opinião do entrevistado, um dos mais completos de franquias no mercado de food service. No manual são descritos os processos básicos do restaurante, os treinamentos, e toda sorte de ações necessárias para operar um restaurante da rede. A característica de formatação intensa de processos descrita na seção anterior é tema do manual, determinando as rotinas que deverão ser adotadas nos restaurantes.

No caso das lojas próprias, o contrato de trabalho, em regime de cargo de confiança entre a Máster Franquia e o Gerente do Restaurante, ou, entre Máster Franquia e Gerente Assistente, é a ferramenta formal que rege a relação em questão. Neste caso, diferente do contrato de franquia, não há qualquer especificação de itens específicos a seguir, o que é substituído pelo poder de Fiat conferido pelo contrato à Máster Franquia, obrigando o gerente a cumprir os procedimentos da empresa, mesmo que não especificados em contrato.

Para garantir o cumprimento do contrato de franquia e o cumprimento dos deveres dos gerentes das lojas próprias, alguns mecanismos são utilizados, conforme detalhado adiante.

\footnotetext{
${ }^{73}$ Durante as entrevistas não se obteve acesso direto ao contrato. Não foi aberta a possibilidade da leitura de seu conteúdo. Para contornar esta limitação, discutiu-se verbalmente o conteúdo básico do contrato com o entrevistado, conforme os tópicos listados no Roteiro de Entrevista (ANEXO II).
} 


\subsubsection{Manual e treinamento on the job}

O Manual do Franqueado é uma parte do contrato que estabelece as rotinas a serem seguidas num restaurante da rede. Porém, a simples existência do Manual não faz efetivamente que as rotinas sejam incorporadas a uma loja. Para que o Manual seja seguido fielmente, o Centro Estratégico investe pesadamente em treinamentos para diminuir a dificuldade natural em assimilar conhecimento dos agentes, aumentando a aderência ao Manual. O entrevistado acredita que apenas $30 \%$ das rotinas são assimiladas pela consulta dos franqueados ao Manual. O restante acaba sendo incorporado via treinamento.

Os treinamentos são divididos em dois tipos básicos: aqueles que são trazidos pela equipe de operações (ou qualquer outra equipe) e o treinamento on the job aplicado pelos Treinadores aos Atendentes recém-contratados. A decisão de manter um regime de treinamento contínuo e intenso sobre a equipe acaba facilitando o cumprimento do contrato.

O desalinhamento contratual pode ser gerado por oportunismo, mas também pode ser gerado pela própria ineficiência humana, conforme discutido no Capítulo 2. No caso do investimento em treinamento, o foco é diminuir a dificuldade de interação entre os agentes gerada pela ineficiência inerente ao processo de transferência de conhecimento que ocorre à medida que qualquer nova equipe tentar adotar os procedimentos descritos no Manual. O mesmo raciocínio aplica-se às lojas próprias, em que a equipe e os Gerentes têm que seguir os mesmos procedimentos operacionais e rotinas descritos no Manual do Franqueado.

Outros mecanismos estão mais preocupados com a faceta do oportunismo e focam o monitoramento dos agentes e a punição ao descumprimento contratual, como alguns casos apontados a seguir.

\subsubsection{Inspeção informal via equipe de operações}

Um destes mecanismos é o de inspeção pessoal do restaurante pela equipe de operações. Conforme visto na Seção 8.2.2, a interação da equipe de operações com os restaurantes 
franqueados e lojas próprias é muito alta, ocorrendo semanalmente com o restaurante próprio e quinzenalmente com as franquias. Um dos propósitos dessa dinâmica de interação é a supervisão e o monitoramento, ou seja, enquanto a equipe atua junto à loja no dia a diada operação, ela exerce também essa função.

\subsubsection{Inspeções formais via equipe de operações}

A equipe de operações também faz visitas formais de inspeção, que são pré-agendadas nos pontos de venda, tanto com o Owner Operator das lojas franqueadas, como com os gerentes dos restaurantes próprios. Esta atividade é unicamente dedicada à avaliação da loja. Uma característica deste mecanismo é que a loja sabe o momento que será visitada e pode prepararse para receber os fiscais. $O$ contrato de franquia define a obrigação do franqueado em permitir a vistoria de seu restaurante.

\subsubsection{Atenção da equipe de operações como medida de performance da Máster Franquia aos franqueados}

Uma forma de as lojas franqueadas avaliarem o apoio acordado no contrato que devem receber da Máster Franquia é por intermédio das visitas da equipe de operações e pela entrega de material de treinamento. Para um franqueado, quanto maior for a intensidade dessas visitas e quanto maior for a oferta de material para treinamento de sua equipe, melhor será sua avaliação do cumprimento das obrigações contratuais por parte da Máster Franquia em apoiar o franqueado na adesão ao Sistema da Rede.

Este ponto é bastante sensível, pois a intensidade em si, o número exato de visitas e oferta de treinamentos, não são especificados em detalhes no contrato. Essa falta de definição é comumente conhecida na relação de franquia por ser um dos principais motivos de conflito entre os agentes, mas no caso da Hamburgeria isso não ocorre, pois, segundo o entrevistado, a empresa tem um dos níveis mais altos de investimento em treinamento às suas lojas, franqueadas e próprias, o que não causa frustração em seus franqueados. 


\subsubsection{Mistery Shopper}

Outra forma de inspeção é feita utilizando a ferramenta de Mistery Shopper. Neste caso, que também é formal, pois a gerencia das lojas está ciente e alinhada com essa prática, uma empresa $^{74}$ independente é contratada para inspecionar o ponto de venda.

Neste exercício, um fiscal desta empresa contratada visita uma loja, atuando como um consumidor qualquer, sem se identificar. $\mathrm{O}$ fiscal à paisana observa uma série de elementos como: limpeza da loja, apresentação dos funcionários (uniformes), cordialidade no atendimento e qualidade da refeição. Como o fiscal não se identifica, a loja não tem como saber exatamente o momento da inspeção, não podendo se preparar apenas para o evento, sendo forçada a ficar em eterna prontidão, mantendo sempre o padrão de qualidade necessário para o momento em que for avaliada.

Além de servir para avaliar a loja, o Mistery Shopper acaba sendo uma ferramenta de incentivo à adesão ao sistema, por pressionar os lojistas a manter ininterruptamente o padrão de qualidade desejado para uma eventual fiscalização. Após as visitas, os fiscais emitem um relatório à Máster Franquia sobre as lojas (próprias e franqueadas) que foram visitadas.

\subsubsection{Acompanhamento do fluxo de compras}

Um mecanismo de controle que caracteriza fortemente a relação entre restaurantes e centros estratégicos é o monitoramento direto exercido pelo centro estratégico sobre a entrada de insumos das lojas. No caso da Hamburgeria, esse mecanismo é bastante eficiente. Como visto anteriormente, as lojas têm uma obrigação contratual de comprar todos os insumos por intermédio da Distribuidora Logística apontada pela Máster Franquia, e esta, a Distribuidora, disponibiliza à Máster Franquia um relatório detalhado dos itens adquiridos por cada restaurante. Desta forma, surge uma possibilidade de a Máster Franquia estimar o volume de

\footnotetext{
${ }^{74}$ Não se obteve acesso ao nome da empresa.
} 
negócios de cada restaurante, por intermédio de seu volume de compras. Lojas próprias e lojas franqueadas são monitoradas desta forma.

\subsubsection{Monitoramento via taxa de royalties}

Um mecanismo exclusivo de monitoramento de lojas franqueadas, complementar ao conhecimento do fluxo de insumos dos restaurantes, é o pagamento da taxa de royalties. Essa obrigação, que também é estabelecida contratualmente, permite à Máster Franquia confrontar o valor total vendido (informado via royalty) com o volume total de insumos consumidos na operação, ou com o relatório de informe de vendas, explicado a seguir.

\subsubsection{Monitoramento via lançamentos contábeis}

As lojas próprias também têm um mecanismo exclusivo de controle. Como são próprias, todo o fluxo de caixa do gerenciamento financeiro do restaurante está disponível à inspeção direta pela Máster Franquia. As lojas franqueadas têm também uma obrigação contratual de disponibilizar um relatório financeiro sobre o fluxo de caixa da loja (discriminando o volume vendido), mas o nível de detalhamento e periodicidade é bem menor. Em termos de periodicidade, uma loja própria pode ter suas contas auditadas on line, a qualquer momento, o que não ocorre na relação entre Máster Franquia e Loja Franqueada.

\subsubsection{Monitoramento do esforço da Máster Franquia via elaboração de campanhas}

O monitoramento da Máster Franquia pelos restaurantes também ocorre. Uma forma das lojas franqueadas avaliarem a performance da Máster Franquia é acompanhando o destino de sua contribuição às campanhas de marketing (taxa de propaganda descrita em contrato ou valor conhecido). Contratualmente, o franqueado deve contribuir para que a Máster Franquia desenvolva as campanhas e deve também aderir a elas. Sendo assim, o franqueado estima a 
performance da Máster Franquia pela qualidade das campanhas entregues às lojas. Este mecanismo funciona da mesma forma que a avaliação das visitas de apoio e treinamento descritas na Seção 8.5.1.4.

\subsubsection{Cultura interna forte como mecanismo de enforcement}

A Hamburgeria tem uma cultura forte voltada a sua marca e a aderência ao seu sistema operacional. O orgulho é um dos sentimentos trabalhados nesse processo e pode ser percebido na entrevista a partir de comentários como:

Nós dizemos que, para trabalhar aqui na na Hamburgeria, um sujeito tem que ter "cat chup nas veias..."

Nossos gerentes de lojas próprias são tão comprometidos quanto os franqueados, tendo verdadeira "dor de dono" quando se referem aos "seus" restaurantes...

Eu tenho franqueados tão comprometidos, que alguns chegam a ser mais 'fieis' ao Sistema da Rede que alguns profissionais da própria Matriz ou Máster Franquia... (informação verbal) ${ }^{75}$

O mecanismo de governança do Modelo de Ménard (2010) em questão é o mecanismo contratual. A existência de uma cultura interna forte estimula o self enforcement dos agentes no cumprimento dos contratos, pois valoriza (orgulho) a possibilidade de estar participando do grupo, trazendo receio a cada indivíduo de ser excluído dessa convivência. Este tipo de mecanismo em que os agentes aderem voluntariamente a um determinado padrão de comportamento funciona da mesma forma que o mecanismo de third party de Ménard (2010), podendo sugerir inicialmente a classificação da cultura interna nesta classe de mecanismos. Porém, o autor define as third parties como mecanismos exógenos à transação, fazendo parte do ambiente institucional. Desta forma, em termos de classificação, a cultura interna acaba sendo melhor classificada como sendo a parte informal do mecanismo contratual.

\footnotetext{
${ }^{75}$ Entrevista concedida pelo Executivo da Hamburgeria. Entrevista I. [fevereiro de 2014]. Entrevistador: Fabio Dolnikoff. São Paulo, 2014.
} 


\subsubsection{O caráter relacional do contrato}

O contrato de franquia é bastante detalhado e deixa pouco espaço a renegociações. A rigor, pode-se notar que há relação de confiança entre o franqueado e a Máster Franquia, mas essa confiança (trust) não gera um caráter relacional voltado a possíveis renegociações no futuro entre os agentes.

A relação é pautada por uma expectativa de que os passos futuros da rede serão decididos de maneira centralizada, pelo centro estratégico, e serão seguidos pelos restaurantes. Essa postura de 'seguidor' assumida pelos franqueados é o que melhor define o caráter relacional do contrato entre Máster Franquia e Owner Operators na Hamburgeria.

Vale comentar que a cultura interna forte, discutida na última seção, também não deve ser confundida com uma característica relacional do contrato, simplesmente por seu caráter informal. A cultura interna forte, neste caso de fidelidade ao sistema e à marca, acaba atuando apenas para reforçar a ideia de um centro estratégico forte (centralizador) sendo seguido (via

contrato) por seus restaurantes, não estimulando um ambiente pós-contratual aberto a renegociações.

\subsubsection{O centro estratégico}

A figura do centro estratégico forte (centralizador) assumida pela Máster Franquia é o mecanismo que mais caracteriza o arranjo da Hamburgeria. Nota-se que a existência da Máster Franquia e sua capacidade de reter uma infinidade de direitos de propriedade da cadeia, conforme detalhado até agora, é condição fundamental para o sucesso do arranjo. Praticamente, todos os mecanismos de governança contratuais descritos até agora dependem da existência do centro estratégico, porque, em última análise, o contrato é sempre celebrado entre uma unidade (o restaurante) e o próprio centro estratégico (Máster Franquia). 


\subsubsection{Third parties}

O mecanismo de thir party é pouco usado na governança da cadeia. Sua maior expressão ocorre no momento em que a Máster Franquia exige que o franqueado respeite sempre um conjunto específico de leis do país, no caso: leis trabalhistas e de vigilância sanitária.

O entrevistado opinou sobre a falta de necessidade de amparar-se em third parties devido ao histórico da empresa ter sido sempre pautado pelo pioneirismo em estabelecer padrões de qualidade em suas rotinas, mesmo em momentos nos quais o ambiente institucional não havia sido formatado nesse sentido. Em sua opinião, a maturidade dos padrões operacionais é tão elevada que não há necessidade de adesão a qualquer outro código de conduta.

\subsubsection{Information based networks}

O mecanismo de redes de informação também foi notado no estudo, pela utilização dos vários comitês de trabalho como parte da tomada de inúmeras decisões. Conforme visto na Seção 8.3, a Máster franquia implementa comitês de marketing, de supply chain, treinamento e de tecnologia da informação (TI) para auxiliar a composição de ideias e resolução de problemas nas áreas citadas.

Os comitês são formados por profissionais de diversas áreas da empresa e contam com a participação dos franqueados, todavia, deve-se entender que o comitê funciona mais como um facilitador de fluxo de informação do que como depositório de direitos de propriedade. Na prática estes comitês têm caráter consultivo e não dão direito a seus participantes de tomarem medidas sem aprovação central.

A ocorrência de comitês é comum em outras cadeias, que podem até transferir certa autoridade a estes órgãos. No caso da Hamburgeria, o poder de decisão transferido é mínimo, levando às afirmativas colocadas na Seção 8.3 de que, na prática, a influência do franqueado nas decisões de marketing como um todo são muito baixas. 
Deve-se esclarecer que além dos comitês a rede também tem uma associação. Esta associação, formada apenas por franqueados, representa os interesses destes empresários em negociações com a franqueadora, em casos de conflitos pós-contratuais. Ela não deve ser classificada como mais uma information based network, pois recebe uma quantidade relevante de direitos de propriedade dos franqueados. Aparentemente, a melhor forma de classificá-la seria como um segundo centro estratégico, cuja atuação teve relevância no período de recompra de certas lojas problemáticas pela Máster Franquia (assunto já comentado anteriormente) e que não interfere na dinâmica do dia a dia da relação entre as lojas franqueadas e a Máster Franquia descrita até agora.

\subsubsection{Governança: quadro geral}

O Quadro 5, apresentado a seguir, ilustra a incidência dos mecanismos de governança do Modelo de Ménard (2010) na Hamburgeria. Apesar da existência dos comitês de trabalho, a classificação mais centralizadora parece ser a mais adequada à rede, devido à baixa capacidade de tomada de decisão destes comitês, além do fraco carácter relacional entre franqueados e franqueadora.

\begin{tabular}{|c|}
\hline $\begin{array}{c}\text { Contratos } \\
\text { Relacionais }\end{array}$ \\
\hline $\mathbf{x x x x x x x}$ \\
\hline $\mathbf{x x x x x x}$ \\
\hline $\mathbf{x x x x x}$ \\
\hline $\mathbf{x x x x}$ \\
\hline $\mathbf{x x x}$ \\
\hline $\mathbf{x x}$ \\
\hline $\mathbf{x}$ \\
\hline
\end{tabular}

\begin{tabular}{|c|c|c|}
\hline $\begin{array}{c}\text { Information- } \\
\text { Based-Networks }\end{array}$ & Third Party & $\begin{array}{c}\text { Centro } \\
\text { Estratégico }\end{array}$ \\
\hline $\mathbf{x}$ & & \\
\hline \multirow[t]{2}{*}{$\mathbf{x}$} & $\mathbf{x}$ & \\
\hline & $\mathbf{x}$ & \\
\hline $\mathbf{x}$ & & $\mathbf{x}$ \\
\hline $\mathbf{x}$ & $\mathbf{x}$ & $\mathbf{x}$ \\
\hline & $\mathbf{x}$ & $\mathbf{x}$ \\
\hline & & $\mathbf{x}$ \\
\hline
\end{tabular}

Quadro 5 - Mecanismos de governança principais da Hamburgeria Fonte: elaborado pelo autor, com base nas entrevistas 
A Figura 21, apresentada a seguir, oferece uma visão da cadeia de suprimentos em que se insere a Hamburgeria. Nesta figura, pode-se observar os mecanismos de governança que regem a interação da Hamburgeria com seus parceiros comerciais.

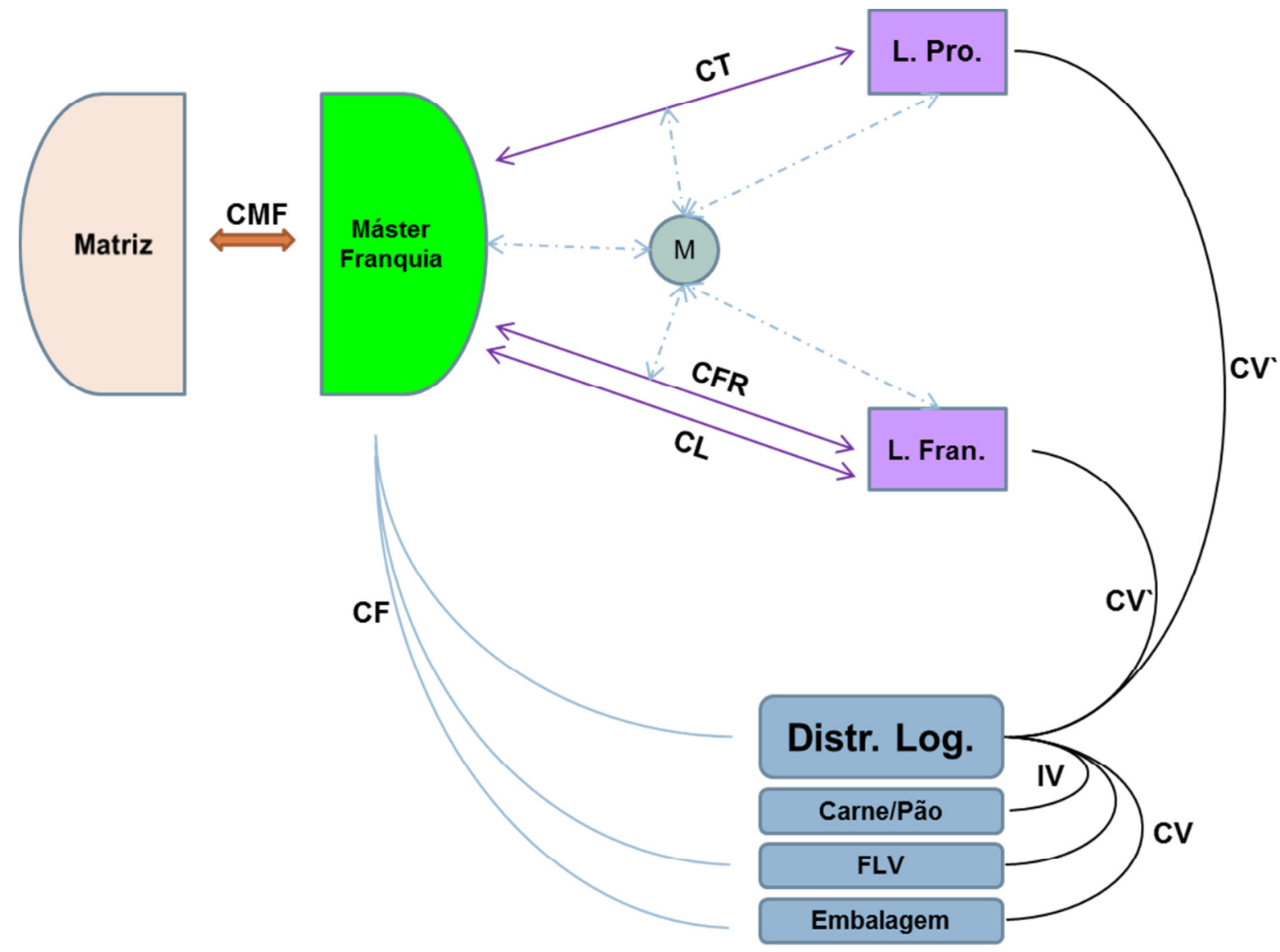

Figura 21 - Mecanismos de governança complementares associados à Hamburgeria Fonte: Fonte: elaborado pelo autor, com base nas entrevistas.

Sob a perspectiva da complementaridade contratual sugerida por Argyres e Liebeskind (1999) e discutida na seção 7.3.2.3, vale destacar dois mecanismos (complementares) de governança que parecem influenciar diretamente a relação bilateral entre a Máster Franquia e suas lojas franqueadas:

O primeiro deles é o contrato de locação de imóvel (CL) celebrado entre a Máster Franquia e o dono do imóvel, e acoplado ao contrato de franquia, que dá suporte à centralização da tarefa de expansão (conforme discussão apresentada na Seção 8.3). O segundo é o conjunto de contratos de longo prazo para fornecimento $(\mathrm{CF})$ de matérias primas celebrado entre a Máster Franquia e o distribuidor logístico, assim como entre a Máster Franquia e alguns 
fornecedores, que suportam a centralização da tarefa de compras (conforme discussão apresentada na Seção 8.3).

\subsection{Resumo do caso}

O Quadro 6, apresentado a seguir, oferece um resumo esquemático com as principais características observadas no Caso da Hamburgeria.

\begin{tabular}{|c|c|}
\hline \multicolumn{2}{|r|}{ HAMBURGERIA } \\
\hline Complexidade & $\begin{array}{c}\text { Alta (indicada por uma grande equipe total, de } 48 \text { profissionais em dois } \\
\text { turnos, por loja). }\end{array}$ \\
\hline $\begin{array}{l}\text { Alocação de Direitos de } \\
\text { Propriedade na rede } \\
\text { (Tarefas Básicas) }\end{array}$ & $\begin{array}{c}4 \text { tarefas são alocadas nas lojas (Produção, Gerenciamento da Equipe, } \\
\text { Marketing de Vizinhança e Gerenciamento Financeiro). }\end{array}$ \\
\hline $\begin{array}{l}\text { Mecanismos de } \\
\text { Governança Principais } \\
\text { (Ménard, 2010) }\end{array}$ & Centro Estratégico e Contrato Detalhado (baixo caráter relacional). \\
\hline $\begin{array}{l}\text { Mecanismos de } \\
\text { Governança } \\
\text { Complementares }\end{array}$ & $\begin{array}{l}\text { a) Contrato de Aluguel entre Centro Estratégico e Locatário viabiliza } \\
\text { centralização da tarefa de Expansão da Rede. } \\
\text { b) Operadora Logística e Contratos de Longo Prazo para fornecimento } \\
\text { viabilizam centralização da tarefa básica de Compras. }\end{array}$ \\
\hline $\begin{array}{l}\text { Controle Efetivo e } \\
\text { Monitoramento }\end{array}$ & $\begin{array}{l}\text { a) Acompanhamento de vendas via Royalties e Taxa de Propaganda. } \\
\text { b) Acompanhamento de compras via Distribuidor Logístico. } \\
\text { c) } 70 \% \text { da rede é integrada (alto controle efetivo). } \\
\text { d) Alta intensidade de Visitas Formais para Inspeção. }\end{array}$ \\
\hline
\end{tabular}

Quadro 6 - Resumo esquemático do Caso Hamburgeria

Fonte: elaborado pelo autor, com base nas entrevistas

Neste quadro, a Hamburgueria foi retratada como uma cadeia de lojas em que a complexidade no ponto de venda é elevada (uma discussão mais completa sobre a classificação da cadeia em função de sua CPV, levando em consideração as outras variáveis do constructo, além do tamanho da equipe, e uma comparação da complexidade entre as cadeias estudadas, será feita no Capítulo 11). 
A governança do arranjo híbrido é feita por meio de um contrato de franquia detalhado (com baixo caráter relacional) entre a Máster Franquia (Centro Estratégico) e lojas franqueadas. Apenas quatro tarefas básicas estão alocadas na periferia da rede, sendo que o contrato de aluguel entre a Máster Franquia e o dono do imóvel e os contratos de longo prazo para fornecimento de matéria prima sustentam a centralização das tarefas de expansão e compras, respectivamente.

O monitoramento é estabelecido de várias maneiras. Entre elas: o acompanhamento das vendas via royalties e taxa de franquia, o acompanhamento das compras via distribuidor logístico (alto controle) e as vistas de inspeção (feitas em alta frequência).

Como a cadeia é franqueada em apenas $30 \%$ de suas lojas, deve-se lembrar de que o controle efetivo sobre a maior parte da rede $(70 \%)$ é total. 


\section{O CASO PIZZA DELIVERY}

O delivery ${ }^{76}$ no Brasil ainda é um segmento pouco consolidado. Apesar de ser significativo em termos de volume de negócios como um todo, a opção pelo delivery como atividade principal ainda é baixa. Na maioria dos casos, o delivery ainda acontece como uma atividade secundária para a maioria dos restaurantes full service. Para o consumidor, a primeira opção em termos de delivery é recorrer aos restaurantes de sua vizinhança. Desta forma, o delivery segue o mesmo padrão pulverizado dos inúmeros restaurantes que compõem o setor de food service no País.

A culinária mais presente no segmento de delivery é a italiana, especificamente ligada à venda de pizzas. Este segmento é tão significativo no Brasil que a característica da pizza nacional chega a ter contornos próprios, fugindo do padrão italiano. No Brasil, o 'recheio' é a parte mais importante do prato, enquanto na Itália (Europa) a massa ainda é a parte mais valorizada. Além da pizza, a culinária oriental, principalmente a chinesa e a japonesa, também tem um lugar de destaque na preferência nacional, quando se trata de delivery.

Apesar da maior parte do delivery estar ligada a restaurantes full service, também existem organizações especializadas nessa atividade. A maioria delas corresponde a operações unitárias, do tipo stand alone, voltadas à produção e entrega de pizzas.

Algumas cadeias também se destacam no segmento de Pizza Delivery. Vale citar: a Domino`s Pizza, A Cezanne, a Dídio Pizza, A Tal da Pizza, Patroni, Pizza Hut e Babbo Giovani. Entre as empresas citadas, a Domino`s e a Pizza Hut são importantes cadeias multinacionais, de origem americana. No Brasil, as duas operam estabelecimentos mistos, oferecendo sempre o delivery junto à possibilidade de consumo em salão próprio. A Tal da Pizza atua da mesma forma. A Dídio Pizza e A Cezanne dedicam-se especialmente ao delivery, enquanto a Babbo Giovani é uma cadeia full service que explora secundariamente a entrega em domicílio.

\footnotetext{
${ }^{76}$ Conforme descrito no Capítulo 5, o delivery é uma categoria de food service em que o alimento é entregue pelo prestador de serviço em um local determinado pelo consumidor. Neste caso, o ponto de venda não oferece estrutura para consume no local.
} 
Depois da pizza, a culinária oriental é a principal opção quando se trata de delivery. A estrutura do mercado é parecida, sendo também uma atividade mais ligada a restaurantes full service do que a empresas especializadas em delivery. Da mesma forma que o segmento de pizzas, a culinária oriental também tem algumas cadeias que se destacam, como: China In Box, Lig-Lig, China House e Gendai.

O China In Box e o Gendai pertencem ao grupo brasileiro Trend Foods, em que a operação de culinária chinesa, a China In Box, é mista, assemelhando-se à proposta de atendimento da Dominos`s. Já o Gendai é bem mais voltado ao atendimento em praças de alimentação, explorando o delivery como atividade secundária. Lig-Lig e China House são exclusivamente voltados ao delivery.

\subsection{A Pizza Delivery}

A cadeia estudada é uma rede inteiramente dedicada ao delivery de pizzas, de nacionalidade brasileira, que opera principalmente na cidade de São Paulo. A rede já acumula mais de 20 anos de experiência neste negócio. A cadeia tem 24 lojas, sendo três delas próprias. Sua atuação é focada no consumo fora da loja, sendo que $95 \%$ de sua produção é distribuída via entrega em domicílio, e 5\% é feita por retirada na loja pelo consumidor final. Em ambos os casos, nunca há consumo na loja.

A estratégia organizacional adotada para as lojas que não são próprias é a franquia, sendo que a grande maioria de seus franqueados é mono operador. A rede atende às cidades da grande São Paulo e a duas cidades do interior paulista. Como será visto mais a diante, a estratégia de expansão da cadeia é extremamente alinhada à otimização logística, havendo pouco interesse da rede expandir suas operações para outros estados no momento. Uma loja da rede fatura, em média, 120 mil reais, operando com uma equipe de 16 funcionários, por um período apenas no dia. Deliveries de Pizza só atendem pedidos no fim da tarde e início da noite. 


\subsubsection{Estrutura física da loja}

Todas as lojas da rede são lojas de rua e a ocupação compreende a parte térrea do imóvel. A localização ocorre, preferencialmente, em ruas e avenidas de grande fluxo de passagem de

carros e pedestres. É importante que a loja, apesar de trabalhar com delivery, seja vista por seus clientes em potencial.

Uma loja contém sempre três divisões: a frente de loja, a cozinha e a área de entrega. A frente de loja é um balcão onde o caixa da loja desempenha suas atividades e é onde um eventual cliente pode ser atendido diretamente. Hoje em dia, o atendimento de telemarketing é centralizado para metade da rede, então, para as lojas que ainda têm seus atendentes próprios, estes atendentes também ficam alocados na frente de loja.

A comunicação entre atendentes e cozinha é eletrônica. Existe um sistema, que é alimentado pelos atendentes, que diz aos operadores da cozinha o que fazer. Desta forma, não há diferença operacional entre lojas com atendimento centralizado ou não, pois o sistema é o mesmo.

Apesar de a pizza ser produzida na cozinha, a embalagem final ocorre na frente de loja, também. A cozinha é o local onde as pizzas são preparadas e forneadas. A característica principal do local é a existência de um forno, de uma bancada (para a montagem das pizzas) e de uma estrutura de câmara fria para guardar os ingredientes perecíveis.

O forno adotado é um forno a gás, de esteira. Esse equipamento é comprado de fornecedores próprios e pode ser removido inteiramente da loja, caso se faça necessário. O forno pode ser abastecido por gás de rua (fornecido pela Comgás) ou por GLP. No caso de uso de GLP, uma estrutura de alvenaria é construída no exterior da loja para abrigar os cilindros de gás que têm de ficar fora da cozinha.

A área de entrega fica no exterior da loja. É o local onde os entregadores aguardam para levar os pedidos, é onde alguns equipamentos de entrega ficam armazenados e é o local onde as motos dos entregadores ficam estacionadas. A Pizza Delivery não tem salão para consumo interno e não permite que um cliente coma no interior da loja, mesmo que ele peça para comer 
em pé, junto ao balcão da frente de loja. Vale comentar que as motos não pertencem às lojas. Elas são propriedade e responsabilidade dos entregadores.

\subsubsection{Linha de produtos}

A linha de produtos é um cardápio típico de pizzas. Oferece 20 tipos de pizzas salgadas, divididas em quatro sabores básicos: as pizzas com queijo, com calabresa, com frango e especiais. As pizzas podem ser pedidas em até dois sabores por unidade. Na linha de pizzas salgadas, a cadeia oferece a pizza em massa tradicional e em massa integral. Além das pizzas salgadas, a rede trabalha com uma linha de pizzas doces. Esta linha é responsável por quase $30 \%$ do faturamento médio de uma loja. Seu sucesso é atribuído à utilização de uma massa especial, desenvolvida internamente, especialmente para este fim. Acompanhando as pizzas, uma loja oferece bebidas como: sucos, refrigerantes e cervejas.

\subsection{Agentes e atores}

A seguir, serão descritos os principais atores averiguados na cadeia, seguindo a proposta colocada no Capítulo 7 de observar separadamente a equipe interna da loja, a equipe dedicada na franqueadora e o franqueado.

\subsubsection{A equipe interna da loja}

A equipe interna da loja segue o seguinte organograma de cargos, conforme ilustra a Figura 22, apresentada a seguir. Nesta ilustração não foi inserida a equipe de atendimento, visto que apenas metade da rede ainda tem estes profissionais na loja e a centralização de todo o atendimento deve acontecer em aproximadamente dois anos. 


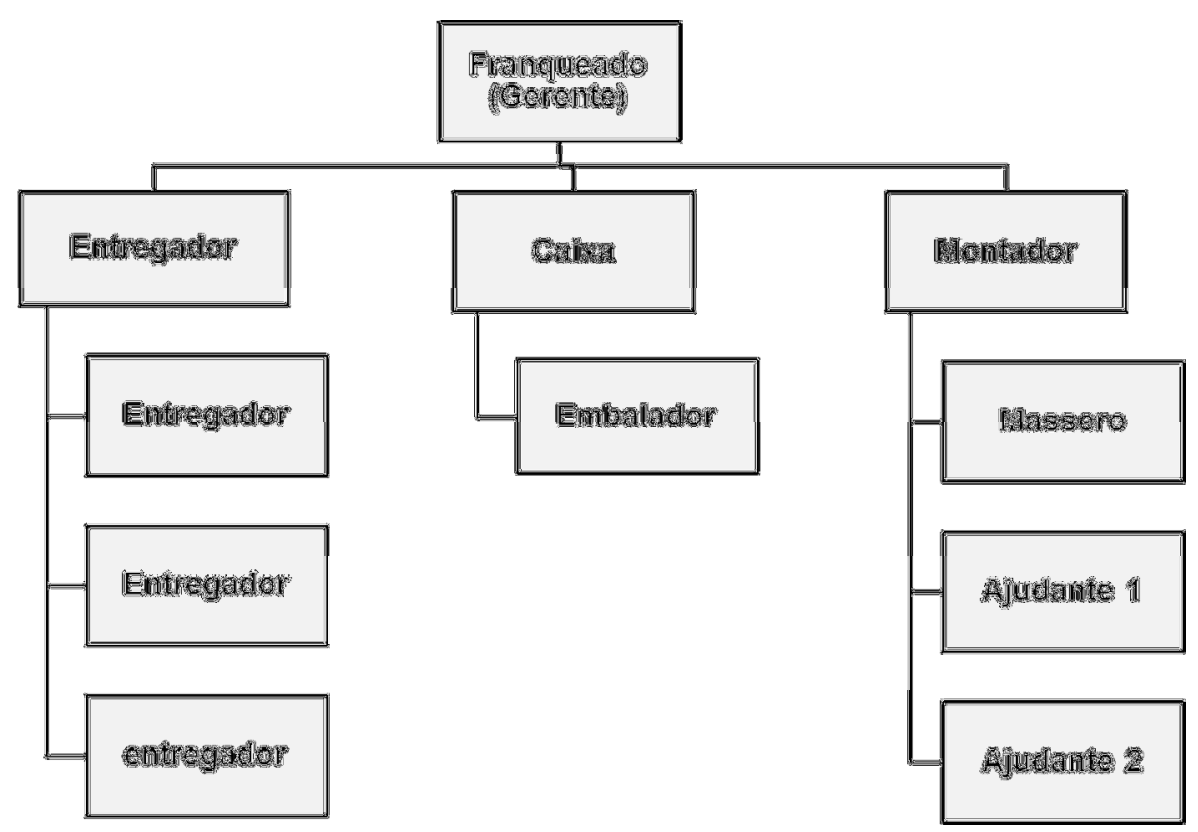

Figura 22 - Organogarama de uma loja da Pizza Delivery

Fonte: elaborado pelo autor com base nas entrevistas

A ilustração mostra uma equipe de 11 pessoas. Esta é a equipe para abertura de uma nova loja. Diferente de outras atividades de food service, uma loja exclusiva de delivery demora um pouco mais de tempo para chegar ao ponto de equilíbrio, sendo assim a equipe vai sendo gradativamente aumentada à medida que o volume de entregas da loja cresce. Na rede, uma das lojas mais antigas, e de maior sucesso, tem cerca de 30 funcionários.

Em termos de crescimento do número de funcionários, espera-se que a equipe passe de 11 a 14 funcionários em dois anos e chegue a 16 funcionários em quatro anos, momento que coincide com a renovação do contrato de franquia.

$\mathrm{O}$ franqueado assume a função de gerente da loja. $\mathrm{O}$ franqueado deve distribuir a autoridade na loja de forma que o montador seja capaz de coordenar a cozinha e o caixa seja capaz de coordenar a frente de loja.

$\mathrm{Na}$ cozinha, apesar de haver especialização do trabalho, todos devem dominar as rotinas de preparar uma pizza do começo ao fim do processo. Uma particularidade deste negócio é a enorme concentração dos pedidos nas noites de quinta-feira a domingo, sendo assim, nos primeiros três dias da semana não há volume de entregas suficiente para justificar uma equipe completa na cozinha e apenas um operador deve ser capaz de conduzir a produção nestes dias. Todos os funcionários têm uma relação celetista com a loja, inclusive os entregadores. 
A figura do gerente profissional também ocorre: nas lojas próprias e em três lojas franqueadas. A orientação da franqueadora é que os franqueados nunca contratem gerentes em suas lojas antes de um período mínimo de dois anos de operação.

\subsubsection{A equipe dedicada na Franqueadora}

No caso da Pizza Delivery, todos os funcionários da Matriz (franqueadora) dedicam-se exclusivamente à rede, pois a empresa não tem outros negócios além da cadeia de food service.

A direção da empresa fica a cargo do sócio fundador. Ele conta com três departamentos para apoiá-lo: os departamentos de operações, marketing e finanças.

O departamento de operações é o maior da empresa, sendo responsável pela expansão, desenvolvimento de produtos e pela coordenação da rede. Este departamento tem seu gerente, dois consultores de campo, um representante de imóveis, uma nutricionista (que tem o apoio de 3 técnicos) e dois assistentes de escritório.

As responsabilidades técnicas, de desenvolvimento de produto, de controle de qualidade e segurança alimentar, ficam alocadas na equipe da nutricionista. Todo o contato com as lojas, próprias ou franqueadas, é feito por intermédio dos consultores de campo.

O Departamento de Marketing tem seu gerente e um assistente, e o Departamento Financeiro apenas o gerente. A empresa conta com o apoio permanente de uma agência de propaganda e uma agência de relações públicas, além de uma empresa que promove ações de marketing especificamente nas redes sociais. 
A Figura 23, apresentada a seguir, ilustra a formação da Equipe dedicada na Franqueadora.

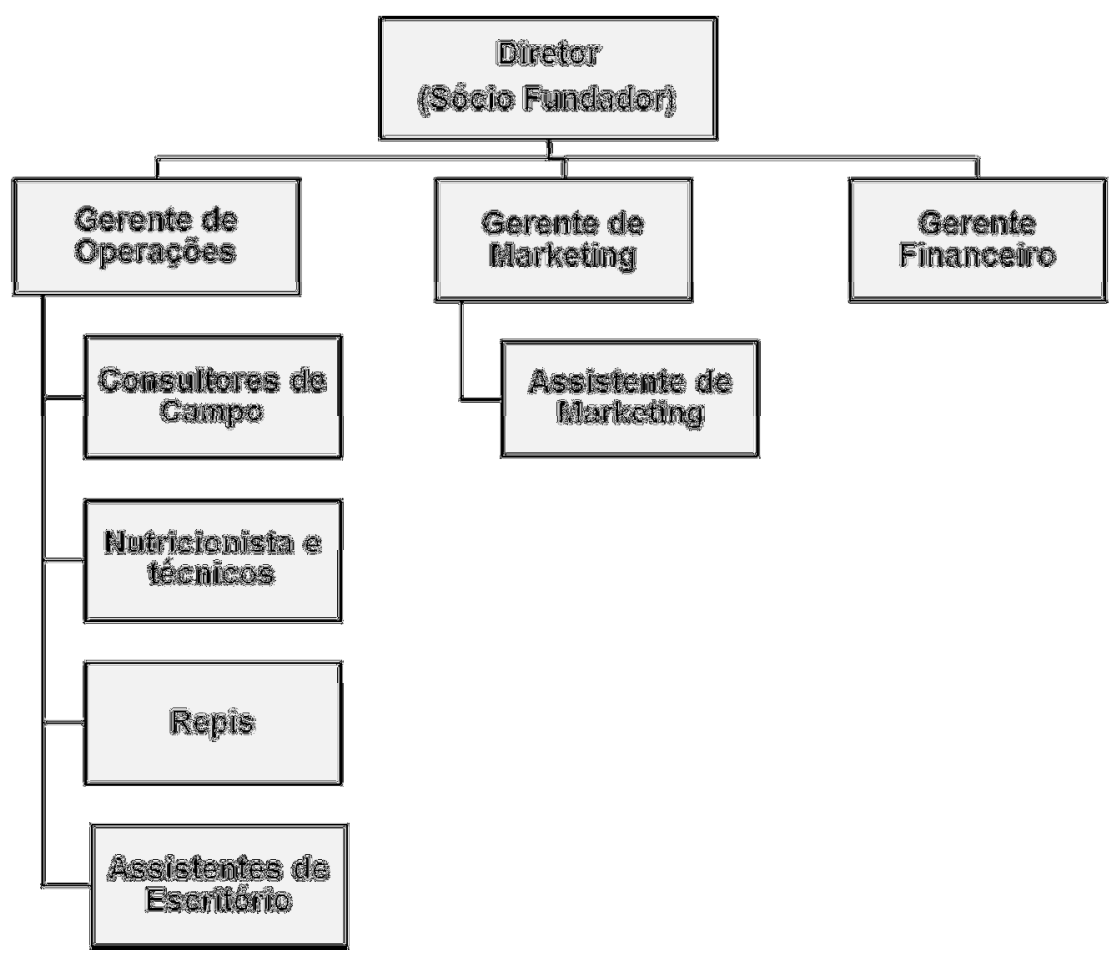

Figura 23 - Organograma da equipe dedicada na franqueadora da Pizza Delivery Fonte: elaborado pelo autor com base nas entrevistas

\subsubsection{O franqueado}

O franqueado deve ser um franqueado operador. Esta é a principal característica do franqueado da Pizza Delivery. Conforme apresentado na seção anterior, na abertura de uma loja nova, o franqueado deverá assumir a gerência da loja e deverá dedicar-se 10 horas por dia ao seu empreendimento. O dia a diado franqueado deve acompanhar o horário de funcionamento da loja, sendo assim, ele acaba dedicando-se ao negócio das $14 \mathrm{~h}$ às $24 \mathrm{~h}$.

Em um dia normal de trabalho, um franqueado deverá dedicar-se inicialmente à atividade de marketing. Esta é uma de suas principais atribuições e espera-se que o franqueado dedique $25 \%$ de seu tempo de trabalho às ações de marketing de vizinhança de sua loja.

As ações de marketing de vizinhança compreendem atividades como: panfletagem (distribuição de cardápios porta a porta, conduzida pelo franqueado e sua equipe), contato 
com condomínios (negociação com porteiros e zeladores para distribuição de material de propaganda e/ou material promocional nos condomínios) e articulação com estabelecimentos comerciais locais para ações conjuntas (ex.: academias de ginástica, postos de gasolina, farmácias etc. Entre estas ações, vale citar o exemplo da relação com academias para promover a pizza de massa integral, desenvolvida exclusivamente pela rede).

A Franqueadora sugere que o franqueado mantenha uma periodicidade em relação às ações de marketing, sempre fazendo as ações no mesmo dia, semana a semana. Estas ações não são interrompidas nunca, nem mesmo quando a loja entra em equilíbrio, tendo formado uma clientela considerável.

Depois de conduzir as ações de marketing previstas para o dia, por volta das $16 \mathrm{~h}$, o franqueado chega à loja e pode se preocupar com atividades de R.H (entrevistar e demitir funcionários), atividades financeiras (folha de pagamentos e fornecedores) e compras (colocação de pedidos). Concomitantemente, o preparo dos ingredientes vai sendo feito por sua equipe na cozinha, o que também é supervisionado pelo franqueado.

Às $18 \mathrm{~h}$, toda a cadeia abre ao público, e o franqueado deve ficar totalmente envolvido na operação de sua loja, que seguirá aberta até às $23 \mathrm{~h}$. Desta forma, espera-se que o franqueado dedique cinco horas diariamente à operação de sua loja, assumindo a função de gerente.

Uma das principais atribuições do franqueado, além de conduzir as ações de marketing de vizinhança, é gerir sua equipe de funcionários. A gerência de equipe inclui a supervisão do trabalho de todos os funcionários e a condução do processo de treinamento. A gerência de equipe ocorre durante todo o tempo em que a loja está aberta ao público, em operação, e é a principal preocupação do franqueado como gerente da loja.

Além de se preocupar com sua equipe durante a operação da loja, o franqueado também dispensa tempo com atividades de R.H (já mencionadas), que fazem parte da gerência de equipe, enquanto a loja permanece fechada ao público. Somando o tempo de dedicação durante a operação e enquanto a loja está fechada, estima-se que $60 \%$ do tempo do franqueado esteja ligado à gerência de sua equipe. 
Apesar de ser de responsabilidade do gerente da loja, em certos momentos, o franqueado pode ter que assumir algumas das atividades operacionais da loja. Em momentos de altíssima demanda, ou quando um funcionário imprescindível vem a faltar, é possível que o franqueado tenha que efetivamente preencher uma lacuna em sua equipe, na cozinha, no atendimento ou até mesmo na entrega. Novamente, fica patente a necessidade de o franqueado ter perfil de operador e não apenas de investidor.

O Gráfico 2, apresentado a seguir, mostra as principais atividades do franqueado e a quantidade de tempo consumido por cada uma dessas atividades diariamente.

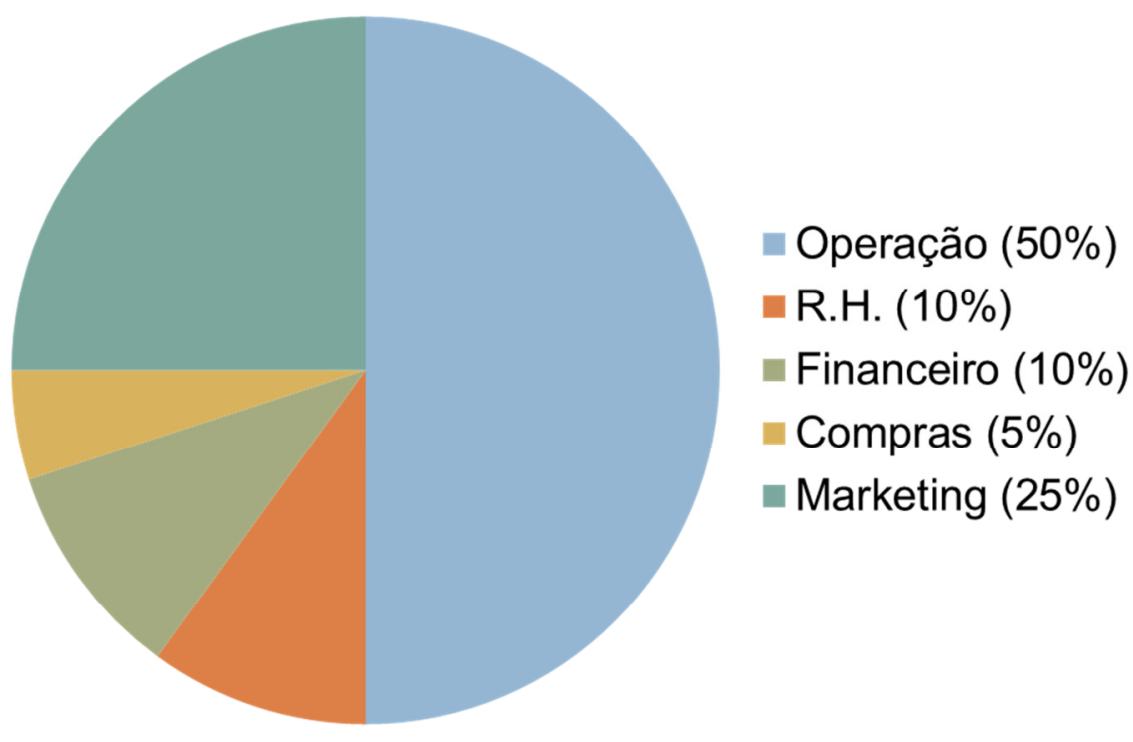

Gráfico 2 - Atividades do franqueado da Pizza Delivery

Fonte: elaborado pelo autor com base nas entrevistas

\subsubsection{O processo de escolha do franqueado}

Se um interessado quiser contatar o escritório da Pizza Delivery, por telefone, ele não irá conseguir. Todo e qualquer contato entre candidatos a franqueado com a empresa é feito por intermédio do site da companhia, tendo como primeiro passo o preenchimento de um cadastro simples pelo candidato, manifestando seu interesse em conhecer a proposta de negócio da Pizza Delivery. 
O site, assim como as embalagens de pizza distribuídas no mercado, servem como veículo de propaganda da oportunidade de negócios oferecida pela franqueadora, e convida os interessados a preencher o cadastro simples, manifestando seu interesse por uma eventual franquia da Pizza Delivery.

Como resposta ao contato dos interessados, a Pizza Delivery promove, quinzenalmente, um evento do tipo palestra em hotel, que é conduzido pelo sócio fundador, onde ocorre o contato pessoal entre as partes.

Neste evento, são apresentadas as linhas gerais da proposta da franqueadora e é entregue aos candidatos um material contendo uma proposta mais detalhada e um plano de negócios com horizonte de dez anos. O evento em si não tem o objetivo de discutir o plano de negócios que está sendo entregue, ele é focado em mostrar aos candidatos o dia a dia de um franqueado para que eles possam formar uma ideia se o perfil da atividade está alinhado ao seu perfil pessoal. A discussão está mais centrada em oferecer ao candidato as informações necessárias para que ele possa averiguar se possui identificação com o negócio ou não.

Desta forma, o evento (palestra) funciona como uma primeira 'peneira' em que o próprio candidato é responsável pela decisão de dar ou não continuidade ao processo. Os candidatos que assistiram à palestra recebem no dia seguinte ao evento um e-mail (com senha de acesso) convidando-os a preencher um cadastro completo no site da empresa, caso ainda estejam interessados em continuar o processo. Neste cadastro, além de apresentar seu perfil de disposição de tempo e capital para investir na rede, o candidato deverá apontar sua área geográfica de interesse.

O cadastro do candidato é analisado e, se ele tiver um perfil bem avaliado pela franqueadora, e tiver um interesse geográfico alinhado ao plano de expansão da rede, o candidato receberá uma Cofi (Circular de Oferta de Franquia) e será convidado para uma atividade de test drive numa loja da rede.

O test drive é um dia de campo completo, em que o candidato tem a oportunidade de acompanhar e participar da operação de uma loja na prática, de preferência a operação de uma loja franqueada, para vivenciar ao dia a dia que ele virá a ter, caso torne-se franqueado da rede. Novamente, o candidato tem uma oportunidade dupla de autoavaliar seu alinhamento 
com o negócio, analisando o conteúdo da Cofi e vivenciando a operação de uma loja na prática. Se o candidato mantiver seu interesse, ele é convidado para uma série de entrevistas com a alta gerência da rede, para que ambos os lados possam ter mais uma oportunidade de avaliar suas contrapartes.

Ultrapassando esta fase, as partes consumam um pré-contrato de franquia, em que a franqueadora se compromete a conceder uma franquia ao candidato para a região combinada, e o candidato efetua o pagamento de parte da taxa de franquia para confirmar seu interesse no negócio. Na maioria das vezes, até este momento o ponto comercial exato onde deverá se estabelecer a nova loja ainda não foi identificado. Assim que o ponto comercial é identificado, é assinado o contrato de franquia definitivo, alinhado ao contrato de aluguel do ponto, que é assinado entre o franqueado e o locatário do imóvel.

Após os dois contratos estarem firmados, começa a reforma do imóvel para que a nova loja possa operar e, ao mesmo tempo, começa o treinamento do franqueado. Aproximadamente 45 dias após o início da reforma, a loja é inaugurada. O treinamento do franqueado coincide com esse cronograma e é finalizado nos mesmos 45 dias. Durante este tempo, o franqueado dedica-se ao treinamento e acompanha pouco a reforma. A supervisão da reforma é feita pela franqueadora.

\subsection{Atividades, responsabilidades e tarefas}

A seguir, serão descritas as principais tarefas averiguadas na cadeia e sua alocação.

\subsubsection{O desenvolvimento dos produtos}

O desenvolvimento de produtos é uma atividade bastante centralizada. As figuras que participam deste processo são: o sócio-diretor (sócio fundador), o gerente de marketing, o gerente de operações, o comitê de marketing, a nutricionista e sua equipe, e a agência de propaganda. Em alguns casos, fornecedores também fazem parte deste processo. 
A empresa tem uma meta anual de fazer quatro campanhas, que envolvem lançamento de produtos. Geralmente o processo tem início no trabalho do gerente de marketing e da agência de propaganda, que formulam uma proposta inicial que é avaliada pela direção e pelo departamento de operações (tanto em relação à viabilidade de fornecimento de matérias primas, como a viabilidade técnica do processo fabril). Esta avaliação conta sempre com a possibilidade de serem realizados testes nas lojas próprias da rede sobre a performance e operacionalidade das propostas levantadas.

Quando a ideia é bem avaliada internamente, ela é levada ao Comitê de Marketing, formado por cinco integrantes: o sócio diretor da franqueadora e quatro franqueados. Note-se que a função do comitê é aprovar ou não uma ação, não tendo a função de trazer sugestões de lançamentos. Outra característica é que as ideias que não são de interesse da franqueadora nem chegam ao fórum de discussão.

Desenvolvimentos como a linha de pizzas doces, que somente foi atingido com a criação de uma massa específica para o produto, assim como o da pizza com massa integral, tiveram esse perfil de andamento.

Outro caminho pode ser trilhado a partir de fornecedores, o que é comum em toda indústria de alimentos. Neste caso, o próprio fornecedor de insumos ou de equipamentos traz uma ideia ou uma proposta nova que usa seus produtos à rede. Depois de captada a proposta, o processo passa a ser o mesmo que o descrito para as propostas geradas pelo marketing.

A expectativa da empresa em relação aos desenvolvimentos está mais ligada a criar um canal de comunicação com seus clientes, gerando um motivo para que a marca seja lembrada, do que emplacar uma novidade arrebatadora no mercado. A rede encara o mercado como sendo bastante estável e vê a necessidade de apresentar novidades mais para 'criar fato' do que efetivamente oferecer novas opções.

De acordo com o entrevistado, o último lançamento significativo neste mercado foi a pizza de rúcula e tomate seco, o que deve ter ocorrido há mais de 15 anos. Todo lançamento é alinhado com o serviço da assessoria de imprensa e da assessoria em mídias eletrônicas, para obter o melhor impacto possível. 


\subsubsection{O desenvolvimento e veiculação de promoções e propaganda}

O desenvolvimento de promoções e propaganda também é bastante centralizado.

Anualmente, a cadeia faz quatro campanhas coletivas, que incluem sempre lançamentos, feitos segundo o cronograma: verão, inverno, data comemorativa (escolhida anteriormente, ex.: carnaval) e natal. Apesar de as campanhas serem coletivas, a rede não investe em propaganda coletiva (institucional) da marca. O único investimento neste sentido é na assessoria de imprensa e na mídia em redes sociais. Em ambos os casos, conforme comentado acima, de maneira centralizada.

Por outro lado, todo material e estratégia de marketing de vizinhança é desenvolvido pela franqueadora. Os panfletos, cardápios e materiais promocionais ligados aos lançamentos são todos desenvolvidos pela agência de propaganda da rede. Ao franqueado cabe arcar com o custo de impressão do material desenvolvido e com a divulgação propriamente dita. Depois que a agência cria o material, o Comitê de Compras, formado pelo Sócio-diretor e três franqueados, aprova os orçamentos de impressão do material. Metade do custo deste material é assumido pelo fundo cooperado e a outra metade deve ser paga por cada franqueado.

O fundo cooperado é um fundo formado pela contribuição mensal de $2 \%$ sobre o faturamento de cada loja. Esta taxa é também conhecida como fundo de propaganda. Na Pizza Delivery, as movimentações e pagamentos via fundo cooperado devem ser aprovadas pelo Comitê de Compras. Uma fonte de recursos adicional do fundo cooperado pode ser via fornecedores, que podem articular com a rede uma ação conjunta e utilizar o fundo como via de contribuição.

Além de desenvolver o material que deve ser usado nas ações de marketing de vizinhança, a franqueadora está envolvida no aprimoramento e orientação dos franqueados para com as técnicas corretas de aplicação das ações. A franqueadora monta uma sugestão detalhada de dias, horários, equipe e rotinas que devem ser adotadas para que as ações sejam efetivas e não um investimento em vão.

Neste ponto de maturidade da rede o conhecimento das rotinas adequadas para o desenvolvimento do marketing de vizinhança é grande. Sobre este assunto, o entrevistado fez 
questão de salientar que, apesar de as trade areas terem suas especificidades, as ações que se deve aplicar são muito parecidas e a diferença no resultado final está mais ligada ao esforço do franqueado em cumprir as metas de divulgação do que a qualquer outra coisa.

\subsubsection{A expansão da rede e a escolha do ponto comercial}

A expansão da rede é gerenciada de maneira centralizada, mas conta também com a participação do franqueado.

Um dos pontos principais, a escolha do ponto comercial, é feito pela franqueadora. Como apresentado anteriormente, o Departamento de Operações conta em sua equipe com um funcionário que se dedica em tempo integral à prospecção de pontos comerciais adequados à rede, o chamado Repis (representante de imóveis).

A busca por novos pontos deve estar alinhada à politica de expansão da rede, que é feita com foco em otimização logística. Desta forma, a cidade de São Paulo passa a ser o epicentro da rede e a expansão é feita em localidades que possam vir a fazer parte da rota de entrega da distribuidora logística que atende à cadeia. Por este motivo, para o ano de 2014, apenas a grande São Paulo e o interior paulista estão no plano de expansão da rede.

Conforme explicado no tópico sobre o processo de escolha do novo franqueado, Seção 9.2.2.1, a escolha definitiva do ponto ocorre após a escolha do franqueado em si. A dinâmica em que o franqueado participa da escolha do ponto ou ajuda ativamente a encontrá-lo não ocorre nesta rede.

Deve-se ficar atento ao fato de que o contrato é firmado entre o locatário do imóvel e o franqueado, dessa forma não é possível dizer que o franqueado não participa desta decisão, pois ele é quem dá a palavra final no caso. Mas, sua participação é moderada, pois, informalmente, a franqueadora toma a frente da escolha do local e até da negociação com o locatário. Na prática, o franqueado apenas aceita ou não a proposta completa da franqueadora, que já vem atrelada a uma avaliação de custo de reforma necessário que o imóvel irá precisar para se adequar à operação de uma unidade da Pizza Delivery. 
Nas palavras do entrevistado (informação verbal) ${ }^{77}$, a proposta de negócios da Pizza Delivery é "chave na mão", ou seja, envolvimento mínimo na montagem da loja por parte do franqueado. $\mathrm{O}$ entrevistado salienta que esta política foi adotada após a rede ter tido muito insucesso em permitir a participação do franqueado neste processo, em várias empreitadas no passado.

\subsubsection{Precificação}

A precificação também é totalmente centralizada. $O$ franqueado não tem nenhuma margem para alterar o preço final do produto. Esta política está alinhada à centralização do atendimento já mencionada anteriormente, pois seria muito difícil centralizar a recepção dos pedidos tendo preços finais variando por região atendida.

A política de centralização do preço final também está alinhada com a proposta de negócios da rede, que tem como objetivo oferecer um sistema de trabalho que inclui um conjunto de parâmetros ótimos para cada item do DRE (Demonstrativo de Resultado) da loja. Todos os parâmetros do DRE estão interligados na geração do resultado final da loja, sendo bastante consistente, por parte da franqueadora, ter uma proposta para cada item em separado.

$\mathrm{Na}$ visão do entrevistado, se a franqueadora escolheu uma determinada área para abrir uma loja é porque seu estudo de geo-marketing indica que nesta área existe demanda para sua linha de produtos no preço padrão da rede, não havendo motivo para ajustar o preço final. Se determinado local não tem consumidores interessados a pagar o preço cobrado pela rede, a franqueadora simplesmente não abre uma loja ali.

\footnotetext{
${ }^{77}$ Entrevista concedida pelo Executivo da Pizza Delivery. Entrevista I. [junho de 2014]. Entrevistador: Fabio Dolnikoff. São Paulo, 2014.
} 


\subsubsection{Definição do mix de produtos da loja}

Esta é mais uma decisão bastante centralizada na rede. A escolha de quais itens serão ofertados não cabe ao franqueado, é uma decisão da franqueadora.

Contratualmente, o franqueado compromete-se a acompanhar a determinação do menu proposto pela franqueadora. Note que nesta rede não há variação de tipos de loja, o que diminui ainda mais a variabilidade na linha de produtos. Além de acompanhar o cardápio proposto pela franqueadora, as lojas franqueadas devem acompanhar os lançamentos de produtos da rede, que estão sempre alinhados às campanhas de marketing da cadeia.

\subsubsection{Atividade de compras}

Conforme exposto no Gráfico 2, na Seção 9.2.2, o franqueado dedica apenas 5\% de seu tempo à atividade de compras, porque, o que ele faz, efetivamente, é colocar pedidos. A aprovação de fornecedores, a negociação dos preços e a escolha do formato de entrega é toda decidida pela franqueadora. O manual de franquia indica um nível de estoque que deve ser mantido e o franqueado coloca os pedidos a fim de repor seu estoque, mantendo-o conforme a orientação da franqueadora.

A rede tem alguns fornecedores que oferecem uma estrutura de entrega completa, ou seja, de baixo custo e numa periodicidade adequada. Este é o caso do fornecedor de embutidos, do fornecedor de laticínios e do fornecedor de bebidas, que abastecem as lojas diretamente. Os outros fornecedores entregam mensalmente uma carga no distribuidor logístico da cadeia, que atende semanalmente as lojas. Todos os fornecedores, incluindo aqueles que atendem a rede via distribuidor logístico, recebem o pedido de compra da rede agregado.

A negociação com cada fornecedor e com o distribuidor logístico é centralizada. O resultado destas negociações é muito importante para o resultado final da rede, que investe seriamente em captar ganhos de escala por meio de negociações coletivas. O próprio diretor da rede, o 
sócio-fundador, é a figura principal no processo de negociação com os fornecedores, sendo apoiado pela gerência de marketing e de operações neste processo.

A rede conta com um comitê de compras, que também participa do processo de aprovação dos fornecedores da rede, mas a participação do comitê é feita no final do processo de aprovação, com interferência mínima. Observa-se que a centralização do abastecimento não é ainda maior porque as lojas estão orientadas a fazer o processo de 'pré-peparo' internamente. Os ingredientes são preparados (cozidos e temperados) e 'porcionados' nas lojas, duas horas antes do início do atendimento aos clientes, diariamente. No futuro, a centralização das compras poderá ser ampliada, caso as lojas passem a comprar apenas produtos semiindustrializados (ingredientes porcionados, pré-processados). Essa mudança aumentaria a centralização como um todo, não apenas no processo de compras.

Além de conseguir ganhos de escala com sua estratégia de compras, a cadeia aposta também em contribuir para a homogeneidade de seus produtos finais e de seus processos em cada loja, por meio de sua estratégia de compras. Diferente de outras cadeias de food service, a Pizza Delivery investe em ter apenas um fornecedor por ingrediente, diminuindo desta forma a possibilidade de variação no processo produtivo, além de aumentar seu poder de barganha frente ao fornecedor concentrando seu poder de compra.

A centralização do processo de compras também serve para diminuir o problema de abastecimento gerado pela sazonalidade em processos de compra de produtos frescos. No negócio de pizzas, este problema concentra-se na compra do tomate, que oferece problemas de abastecimento e volatilidade de preços durante o ano. Mantendo a compra concentrada, a franqueadora consegue articular contratos de longo prazo diretamente com produtores rurais, o que diminui bastante esta problemática para a rede.

\subsubsection{Uso de sistemas de gestão no restaurante}

O uso de sistemas de gestão é intenso na rede e o principal sistema usado é o sistema de captação de pedidos. 
Conforme descrito na Seção 9.1.1, ao discutir a estrutura física da loja, a rede passa atualmente por um processo de centralização da atividade de atendimento telefônico para captação dos pedidos, sendo que em torno de 50\% das lojas utiliza uma central de telemarketing centralizada, comandada pela franqueadora.

Os atendentes da central e os atendentes das lojas que ainda não aderiram à central de telemarketing recebem os pedidos por telefone e utilizam um sistema eletrônico que transmite a cada cozinha, em tempo real, a informação sobre o tal pedido, para que os operadores manipulem os alimentos necessários para atendê-lo. O sistema eletrônico adotado foi desenvolvido centralmente e permite à franqueadora acompanhar em tempo real toda operação de suas lojas próprias e franqueadas. Sem este sistema, não seria possível responder rapidamente aos pedidos dos clientes de maneira organizada, nem centralizar a operação de atendimento telefônico. Adicionalmente, outra atividade que utiliza um sistema específico é a atividade de compras. Novamente, via sistema desenvolvido centralmente, que dá transparência total a esta operação. Em ambos os casos, a escolha do sistema a ser adotado foi totalmente centralizada.

\subsubsection{Formação e gerenciamento de equipe}

A responsabilidade direta sobre a gestão da equipe é do franqueado. A franqueadora participa deste processo, mas a responsabilidade acaba sendo mesmo do franqueado.

A franqueadora oferece o treinamento inicial da equipe. Conforme apontado durante a discussão do processo de escolha do franqueado, na Seção 9.2.3.1, a franqueadora oferece um treinamento intensivo de 45 dias para o franqueado e sua equipe logo após a assinatura do contrato de franquia e do contrato de locação do imóvel. Este treinamento é feito nas dependências do escritório central da franqueadora, e é coordenado pelo Gerente de Operações.

O treinamento é dividido em módulos, como: preparação da pizza, rotinas financeiras, rotinas de marketing de vizinhança, rotinas de treinamento, atendimento ao público etc. Passados os 45 dias de treinamento inicial, espera-se que o franqueado seja capaz de operar sua loja e de 
gerenciar o treinamento de novos funcionários. Todas as rotinas de treinamento são passadas ao franqueado, que se capacita a treinar os funcionários que vierem a fazer parte de sua equipe, após esta fase inicial.

A franqueadora continua dando apoio ao franqueado depois do treinamento inicial no que se refere aos novos funcionários, mas a responsabilidade de treiná-los é do franqueado. Na prática, a franqueadora geralmente aceita receber em suas dependências alguns novos funcionários de uma loja, mesmo após a fase de treinamento inicial, mas esta prática não é feita por obrigação contratual, nem ocorre com tanta frequência. Assim, não existe um compromisso formal em que a franqueadora assume parte da responsabilidade do treinamento dos novos funcionários.

A questão dos novos funcionários é importante, pois o turn over da equipe é acentuado no mercado de food service. O entrevistado acredita que sua média de turn over é um pouco menor que a do mercado em que atua, chegando a $70 \%$ em um ano. Mesmo assim, é muito significativa, fazendo do treinamento e do gerenciamento de equipe um tópico de importância central.

A captação dos funcionários também é responsabilidade do franqueado, desde a equipe inicial. Novamente, a franqueadora oferece ao franqueado uma série de rotinas para este processo também, bem como insiste que o franqueado adote uma política de cargos e salários para sua equipe por ela definida. A franqueadora oferece às lojas uma proposta de estrutura de remuneração com níveis salariais, benefícios e metas para cada funcionário e defende ${ }^{78}$ que esta seja a forma mais eficiente de contratação de uma equipe para atuar neste negócio.

Na política de remuneração adotada pela franqueadora, costuma-se oferecer aos funcionários o piso da categoria e um bônus por desempenho. Entre as metas de desempenho estão condutas como:

- Não faltar, especialmente aos sábados;

- Não faltar, sem ser por motivo de saúde;

- Não consumir mais de $10 \%$ de seu salário na loja;

- Atendentes não devem cometer mais que dois erros por mês ao gerarem pedidos;

\footnotetext{
${ }^{78}$ Este conteúdo está descrito no manual.
} 
- Atendentes não devem se estender por mais que um minuto e meio por chamada;

- Entregadores que erram, esquecendo qualquer item de entrega, recebem apenas o fixo e deixam de receber a taxa de entrega.

Apesar de esta política fazer parte do manual do franqueado e ser obrigação de cada um deles adotá-la, a franqueadora, em última instância, costuma 'orientar' o que o franqueado deve fazer com a equipe, não tendo o costume de punir efetivamente um franqueado que divirja desta orientação. Na prática, a franqueadora consegue a cooperação do franqueado no que diz respeito à adoção de sua política de pessoal por meio de orientação e 'pressão', obtendo o resultado que acha satisfatório evitando chegar a qualquer disputa litigiosa com seus franqueados.

\subsubsection{Gerenciamento financeiro}

A responsabilidade de gerir o fluxo de caixa de uma loja da rede é inteiramente do franqueado.

Como na maioria das cadeias de food service, é necessário bastante atenção para gerir o pagamento de fornecedores e funcionários. No caso da Pizza Delivery há uma simplificação da relação com os fornecedores, pelo fato de ela ser toda articulada centralmente. Mesmo assim, a responsabilidade de efetuar os pagamentos é grande, e é toda assumida pelo franqueado. Não fugindo a uma característica peculiar de muitas redes franqueadas, é comum a participação de parentes próximos do franqueado, geralmente seu cônjuge, nesta atividade.

\subsubsection{Alocação dos direitos de decisão: quadro geral}

A Figura 24, apresentada a seguir, ilustra a alocação típica de direitos de propriedade da Pizza Delivery. Comparativamente, observando apenas a alocação de tarefas, a Pizza Delivery tem 
como principal diferença da Hamburgeria (apresentada no capítulo anterior) a maior descentralização da atividade de "expansão da rede e ponto comercial".

\section{Franqueadora}

\section{Franquia}

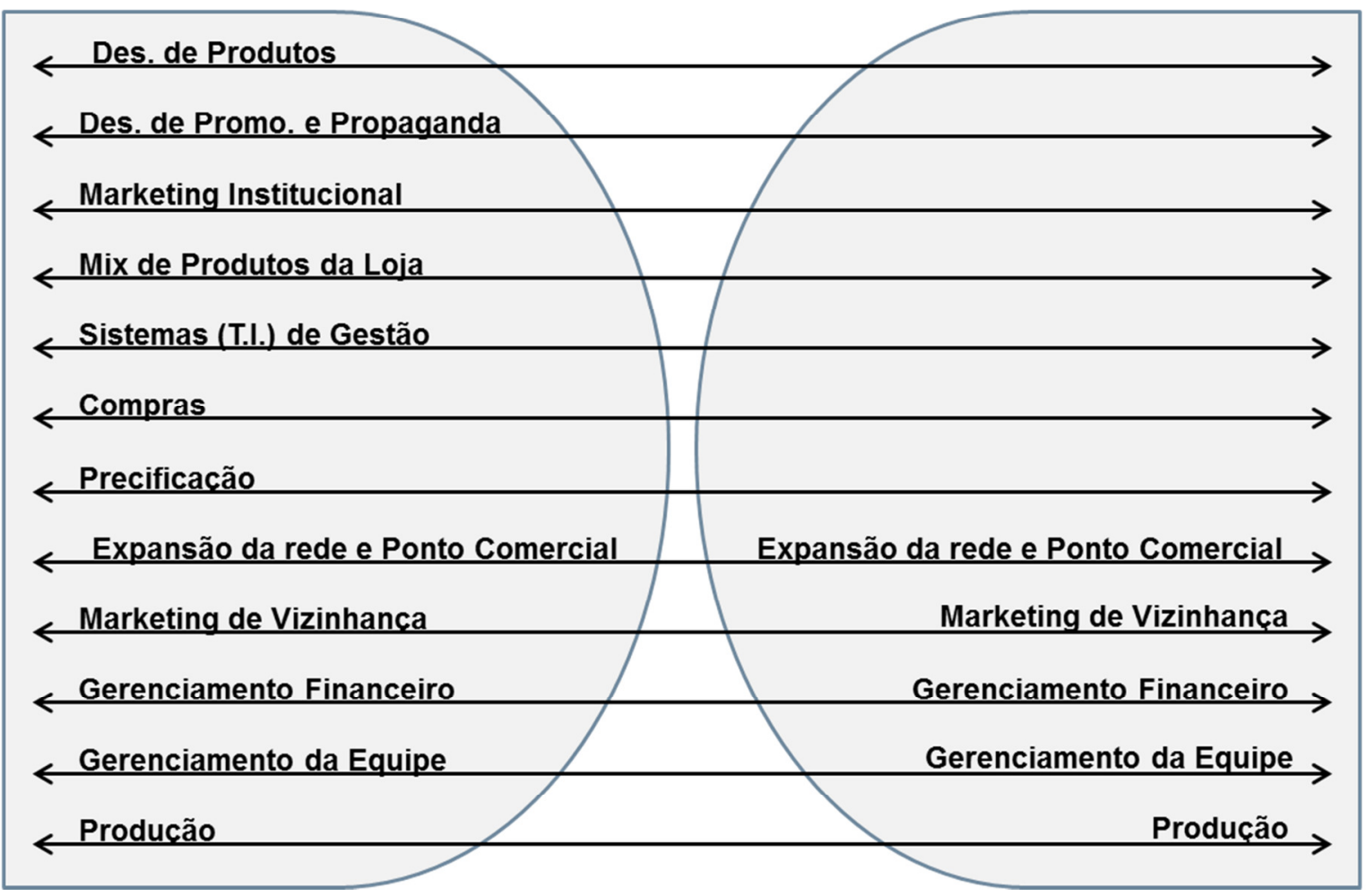

Figura 24 - Alocação dos direitos de decisão na Pizza Delivery (Quadro Geral)

Fonte: elaborado pelo autor com base nas entrevistas

\subsection{Complexidade}

Conforme a proposta de pesquisa apresentada no Capítulo 7, a complexidade é analisada a partir de seu caráter fabril (manipulação) e de seu caráter de serviços (atendimento). O caráter fabril é determinado pelo número de etapas do processo de produção, pela intensidade tecnológica adotada, pela aderência ao uso de rotinas, pelo volume de produção e qualidade (nível) dos alimentos produzidos e pelo tamanho da equipe envolvida neste processo. O caráter de serviços do constructo é determinado pela extensão do atendimento, pela estrutura deste atendimento, pelo volume de clientes atendidos no restaurante a certo nível de atenção 
(qualidade do atendimento) e pelo tamanho da equipe envolvida nessa atividade. A seguir, cada uma destas dimensões referentes ã Pizza Delivery é observada em detalhes.

\subsubsection{Etapas no processo produtivo}

O número de etapas do processo produtivo é médio. A atividade produtiva requer porcionamento de ingredientes, inclui a abertura das massas e o forneamento. Apesar de tratar-se de um único produto, com variações de sabor, há um numero considerável de tarefas, o que indica uma classificação média quanto às etapas no processo produtivo.

\subsubsection{A intensidade técnica do preparo}

A intensidade técnica do preparo é média também. Aparentemente, mais alta que a de seus concorrentes diretos stand alone. Para a Pizza Delivery, existem cinco processos principais no preparo da pizza: o pré-preparo dos ingredientes, o preparo da massa, a montagem da pizza, o forneamento e a embalagem. Todos eles são tecnificados.

O pré-preparo consiste na preparação e porcionamento dos ingredientes. Alguns ingredientes precisam ser cozidos e temperados, como frango, brócolis, berinjela e abobrinha. Outros precisam apenas ser 'porcionados', ou seja, reservados e acondicionados em quantidade suficiente para a confecção de meia pizza.

O preparo da massa utiliza batedeiras semi-industriais. A empresa também conseguiu recentemente incluir em sua cozinha um equipamento automático para 'abrir' a massa, antes da montagem. A montagem é o processo em que um integrante da equipe da cozinha, o montador, utiliza os ingredientes já 'porcionados ‘ para montar a pizza que será forneada. Os 
itens produtivos ${ }^{79}$ utilizados no preparo são aproximadamente 50. Estes itens podem ser agrupados em itens congelados, refrigerados e frescos.

O forneamento é feito em um forno de esteira a gás. Diferente da maioria das pizzarias, que usam o forno a lenha, a Pizza Delivery, que inicialmente também usava forno a lenha, reestruturou-se nos últimos anos e passou a utilizar este equipamento. $\mathrm{O}$ forno de esteira a gás é um equipamento altamente tecnificado, que reduz muito as possibilidades de variações no processo de forneamento da pizza. Ao adotar o forno a gás, a mudança na operação foi tão significativa, que a cozinha deixou de ser comandada por 'pizzaiolos', os quais foram substituídos por 'montadores de pizza'.Cumpre observar que a última parte do processo, que inclui o corte da pizza e seu acondicionamento, também conta com utensílios próprios para esta tarefa.

\subsubsection{Rotinas}

O preparo é razoavelmente bem formatado em relação às rotinas, que foram desenvolvidas pela franqueadora e constam do manual do franqueado.

Algumas opções feitas no desenho do processo produtivo desenvolvido pela franqueadora estão bastante alinhadas à ideia de permitir o estabelecimento de rotinas e conseguir um padrão de produto final com baixa variação. A compra centralizada, com a preferência por um único fornecedor por item produtivo, diminui a variação no processo, facilitando o estabelecimento de rotinas. Ademais, o 'porcionamento' dos ingredientes antes da montagem e a utilização do forno a gás com esteira são opções que também diminuem a variabilidade processual. Por fim, vale lembrar que a comunicação entre o atendente e a cozinha é eletrônica, fazendo com que o pedido entre na cozinha via sistema, o que também facilita a formatação do processo. Considerando-se esse contexto, a Pizza Delivery, comparada a seus concorrentes diretos stand alone, apresenta nível de formatação bem maior; em relação às cadeias de food service, tal nível é intermediário.

\footnotetext{
${ }^{79}$ O termo 'item produtivo' está sendo utilizado aqui com o mesmo sentido ao qual foi utilizado no Caso da Hamburgeria, referindo-se aos itens comprados de fornecedores para a confecção da pizza.
} 


\subsubsection{Volume de produção}

Como o negócio tem seu faturamento totalmente baseado no delivery, é primordial que a loja seja capaz de operar bem em situações de pico de demanda, pois a concentração dos pedidos nas noites de sexta-feira, sábado e domingo é muito alta, e tudo se concentra em um único período de atendimento.

A Pizza Delivery adota uma estratégia de concluir um atendimento em até trinta minutos, em média. A coleta do pedido não deve exceder um minuto e trinta segundos. O preparo e forneamento devem ser concluídos em doze minutos e o restante do tempo é reservado à entrega. Apesar de sofrer com a pressão de entregar a tempo, o volume de alimentos não é grande. Ademais, cada entrega equivale a uma refeição completa para mais de uma pessoa.

\subsubsection{Nível do produto}

A sofisticação do prato é intermediária.

A proposta da Pizza Delivery é atendida ao oferecer uma boa relação entre o custo/benefício aos seus clientes. A Pizza não é a mais sofisticada da cidade, mas é uma ótima opção dentro de sua faixa de preço.

\subsubsection{Equipe de produção}

A intensidade do uso de mão de obra no processo produtivo é intermediária.

Conforme descrito anteriormente, várias decisões foram tomadas para simplificar o processo produtivo. O sucesso desta empreitada teve como resultado uma possibilidade de formatar rotinas e uniformizar o processo produtivo, sem ter a ambição de diminuir significativamente 
a dependência deste processo ao uso mão de obra. Na prática, a equipe de produção equivale a toda equipe da loja, exceto os entregadores, pois o atendimento telefônico é centralizado. Conforme visto na Seção 9.2.1, a equipe de uma loja com aproximadamente quatro anos de operação é de 16 funcionários em um único turno, sendo dez deles ligados à operação fabril e seis às entregas.

\subsubsection{A extensão do atendimento}

A extensão do atendimento é baixa.

A proposta da empresa é não oferecer qualquer estrutura de atendimento, nem acompanhar o cliente durante o consumo. Esta é a característica de qualquer empresa que se propõe a trabalhar exclusivamente com delivery. Vale lembrar que, de acordo com as definições assumidas ao propor o constructo de complexidade no ponto de venda, o atendimento telefônico que ocorre no ato do pedido não deve ser considerado como componente da extensão. Ao discutir a extensão, assim como todos os critérios de atendimento, o constructo se refere ao ato de consumo, ou seja, atendimento durante o ato de consumo.

\subsubsection{A estrutura de atendimento}

A estrutura de atendimento é intermediária.

Apesar de não dispor de estrutura para o consumo, existe uma estrutura de entrega bastante sofisticada, com um número alto de entregadores e motocicletas à disposição desta tarefa. Comparativamente, nenhum estabelecimento deste porte que não tem foco no delivery apresenta uma estrutura de entrega tão grande e aparelhada. 


\subsubsection{Volume do atendimento}

Alinhado ao que foi dito sobre o baixo volume de produtos na seção 9.4.4., efetivamente, o número de pedidos não é grande por loja.

\subsubsection{Nível do atendimento}

Tanto o atendimento telefônico como o contato com os entregadores é educado, cordial e muito rápido. O padrão é bastante parecido com o da Hamburgeria, ou seja, intermediário.

\subsubsection{A equipe de atendimento}

Classificando a equipe de atendimento como a equipe de entregadores, dado que as atendentes do call center estão centralizadas, mesmo assim chega a ser uma equipe intermediária, contando com seis entregadores por loja, operando apenas um turno por dia.

\subsubsection{Complexidade: quadro geral}

A seguir, conforme ilustra a Figura 25, será retomado o quadro completo do constructo de complexidade no ponto de venda, com o intuito de incluir na figura as informações observadas sobre o caso específico da Pizza Delivery.

As entrevistas mostraram que entre todos os itens que formam o constructo, o entrevistado indicou o 'tamanho total da equipe na loja' como sendo o de maior impacto sobre a complexidade no ponto de venda. Quanto aos outros itens, não houve indicação que pudesse levar a uma ponderação de seus impactos. $\mathrm{O}$ entrevistado também insistiu na importância de se considerar o esforço do franqueado e de sua equipe com as práticas de marketing de 
vizinhança como um fator determinante do desafio de cada loja e, consequentemente, determinante da complexidade no ponto de venda. De acordo com o entrevistado, a grande importância e dedicação necessária ao marketing de vizinhança seria uma particularidade de negócios voltados exclusivamente ao delivery.

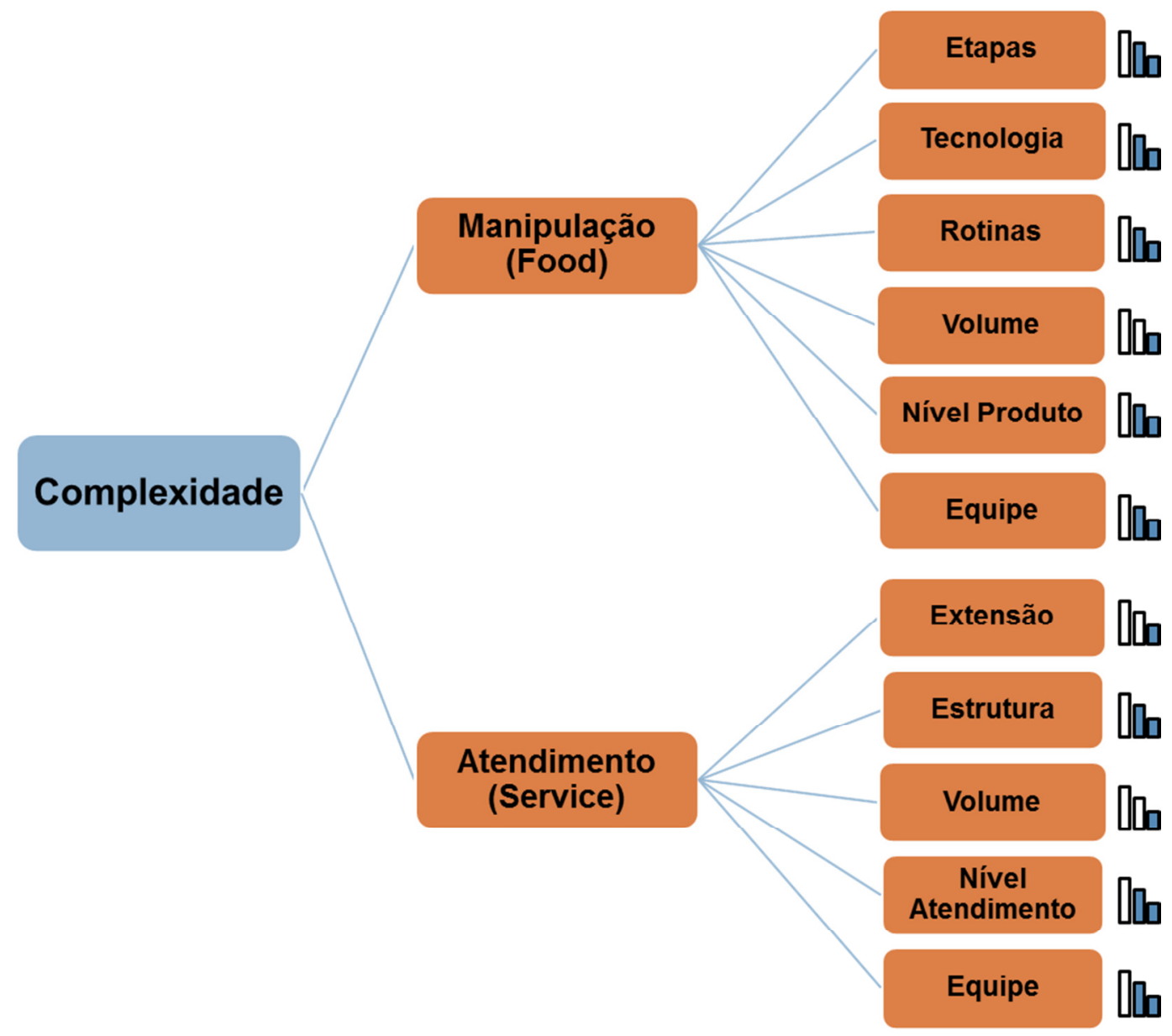

Figura 25 - A complexidade no ponto de venda da Pizza Delivery

Fonte: elaborado pelo autor com base nas entrevistas

\subsection{A governança da relação entre a Franqueadora e suas lojas}

Utilizando o Modelo de Ménard (2010) como estrutura de análise da governança na relação entre uma franqueadora e suas lojas, será apresentada a seguir uma discussão sobre como cada um dos quatro mecanismos apontados pelo autor ocorre na Pizza Delivery, detalhando a relação entre franqueadora \& lojas próprias e franqueadora \& lojas franqueadas. 


\subsubsection{O contrato de franquia ${ }^{80}$}

O contrato de franquia da Pizza Delivery segue um padrão muito próximo ao da Hamburgeria apresentada no capítulo anterior, ou seja, também é um contrato bastante completo. Novamente, a intenção do desenho contratual é deixar poucas possibilidades de renegociação para o futuro.

Na relação entre franqueado e franqueadora, a preocupação está centrada em preservar a marca da franqueadora de possíveis ações por parte do franqueado que possam comprometêla, e possibilitar acesso ao franqueado ao uso da marca e do sistema desenvolvido pela franqueadora. Entre as obrigações assumidas pelo franqueado, está o compromisso de pagamento de royalties, taxa de propaganda e adesão ao sistema da rede. A adesão à rede é formalizada pelo pagamento da taxa de franquia e pelo compromisso assumido em seguir o manual do franqueado. No caso das lojas próprias, o contrato de trabalho entre a Franqueadora e o gerente da loja é a ferramenta formal que rege a relação em questão. Para garantir o cumprimento do contrato de franquia e o cumprimento dos deveres dos gerentes das lojas próprias, alguns mecanismos são utilizados, conforme o detalhamento apresentado a seguir.

\subsubsection{Manual e treinamento}

O Manual do Franqueado é a peça do contrato que estabelece os detalhes sobre como as lojas devem ser operadas. Como apresentado até agora, o Manual da Pizza Delivery não está limitado apenas às rotinas operacionais que uma loja deve seguir. Conforme discutido anteriormente, o manual também formata o perfil de cargos e salários ideal para a equipe de uma loja e indica o equilíbrio ideal entre os itens do Demonstrativo de Resultado a ser perseguido pelo franqueado.

\footnotetext{
${ }^{80}$ Durante as entrevistas não se obteve acesso direto ao contrato. Não foi aberta a possibilidade da leitura de seu conteúdo. Para contornar esta limitação, novamente, discutiu-se verbalmente o conteúdo básico do contrato com o entrevistado, conforme os tópicos listados no Roteiro de Entrevista (ANEXO II).
} 
A franqueadora costuma tomar uma posição de orientadora para com seus franqueados, evitando efetivamente puni-los caso não sigam exatamente todas as determinações descritas no manual. Nas palavras do sócio-diretor, a expectativa da franqueadora é que os consultores de campo detectem qualquer desalinhamento e 'orientem' os franqueados para o caminho prescrito no manual. Na prática, a punição efetiva (litigiosa) por descumprimento do manual costuma não ocorrer.

Como já se esperava, as rotinas a serem seguidas numa loja são uma parte importante do conteúdo do manual, que são reforçadas por uma política de treinamento intenso da equipe das lojas (incluindo o treinamento do franqueado como gerente de loja). Os treinamentos são divididos em dois tipos básicos: aqueles que são trazidos pela equipe de operações (pelo consultor de campo) e o treinamento on the job aplicado pelo gerente (franqueado) aos recém contratados. O mesmo raciocínio é aplicado às lojas próprias, em que a equipe e os Gerentes têm de seguir os mesmos procedimentos operacionais e rotinas descritos no Manual do Franqueado. Por fim, identifica-se que outros mecanismos estão mais preocupados com a faceta da diminuição do oportunismo e focam o monitoramento dos agentes e a punição ao descumprimento contratual, como alguns casos apontados a seguir.

\subsubsection{Inspeções formais via equipe de operações}

O consultor de campo faz duas visitas mensalmente a cada loja, sendo ela uma loja franqueada ou própria. Existem dois tipos de visitas: a visita completa e a visita técnica. Em ambos os casos, as visitas são sempre formais e previamente agendadas. A visita completa dura um dia inteiro, e o consultor tem como objetivo acompanhar todos os processos da loja, preferencialmente nos dias de maior movimento. A visita técnica dura apenas algumas horas e tem por objetivo dar apoio ao franqueado num assunto específico que ele esteja com dificuldade. Se necessário, um técnico da franqueadora acompanha o consultor de campo nesta visita. O contato dos consultores de campo é feito impreterivelmente com os franqueados, mesmo que a loja tenha um gerente profissional. Só nas lojas próprias o contato é feito diretamente com os gerentes. Inspeção e orientação são feitas concomitantemente. Apesar de as visitas terem o intuito de dar apoio ao franqueado, o consultor sempre reporta o andamento da loja à franqueadora. 


\subsubsection{Inspeção informal via equipe de operações}

O contato no dia a dia de qualquer loja com seu respectivo consultor de campo sempre resulta em uma possibilidade informal de supervisão e orientação, porém esse fluxo de informação não chega a ser relevante na relação entre franqueadora e franqueados.

\subsubsection{Atenção da equipe de operações como medida de performance da franqueadora para franqueados}

Algumas redes de franquia não estipulam contratualmente de forma exata a periodicidade das visitas da equipe de operações às lojas franqueadas, dando margem a uma futura frustração por parte dos franqueados quanto ao apoio recebido. Não é este o caso na rede da Pizza Delivery, conforme mostra a seção anterior. Para o franqueado, a qualidade da atenção acaba sendo sua medida de performance da franqueadora, pois a quantidade (duas visitas mensais) foi bem definida desde o início da relação.

\subsubsection{Mistery Shopper}

Esta ferramenta não é utilizada na rede. Nas palavras do entrevistado (informação verbal) ${ }^{81}$ : "se toda loja consegue se preparar duas vezes por mês para visitas agendadas, ela está bem preparada o mês inteiro..."

\subsubsection{Acompanhamento do fluxo de compras}

O acompanhamento é total. As compras são centralizadas e permitem à franqueadora acompanhar a operação de cada uma das lojas.

\footnotetext{
${ }^{81}$ Entrevista concedida pelo Executivo da Pizza Delivery. Entrevista I. [junho de 2014]. Entrevistador: Fabio
} Dolnikoff. São Paulo, 2014. 


\subsubsection{Monitoramento via acompanhamento de vendas}

A Franqueadora tem acesso em tempo real à informação de volume de vendas de suas lojas, dado que o sistema de pedidos é centralizado e aberto. Ademais, a cada três meses cada loja franqueada deve apresentar um relatório de suas vendas à franqueadora. No caso das lojas próprias esse acompanhamento é diário, pois a contabilidade da loja é feita pela matriz.

\subsubsection{Monitoramento via taxa de royalties}

Novamente, este outro indicativo mensal de faturamento permite à franqueadora monitorar bem suas lojas.

\subsubsection{Monitoramento do esforço da franqueadora via elaboração de campanhas}

Uma forma de as lojas franqueadas avaliarem a performance da franqueadora é acompanhando o desempenho das campanhas coletivas propostas ao longo do ano e do material promocional desenvolvido. $\mathrm{O}$ franqueado sempre está atento à qualidade do apoio prestado a ele e à eficácia das propostas mercadológicas trazidas pela franqueadora.

\subsubsection{Cultura Interna como mecanismo de enforcement}

A Pizza Delivery ainda é uma rede jovem e tem apenas 24 lojas. Mesmo assim, foi possível notar a preocupação do sócio diretor em estabelecer uma cultura corporativa que reforçasse o contrato de franquia. Cooperação e padronização parecem ser as bases do código de conduta 'pregado“ pelo sócio-fundador. 


\subsubsection{O caráter relacional do contrato}

O caráter relacional do contrato é muito pequeno. Nas palavras do entrevistado (informação verbal) $)^{82}$ : "o perfil do franqueado da Pizza Delivery deve ser o de uma pessoa que se identifica com um ambiente em que irá seguir uma série de condutas pré-determinadas”. Esta frase reflete bem a postura da franqueadora de não ter qualquer expectativa em dividir suas responsabilidades quanto à rede no futuro, mantendo sempre uma postura transparente e cooperativa (conforme a cultura interna sendo implantada), mas centralizadora.

\subsubsection{O centro estratégico}

A figura do centro estratégico forte (centralizador) assumida pela franqueadora é o mecanismo que mais caracteriza este arranjo. Todos os mecanismos de governança contratuais descritos até agora dependem da existência do centro estratégico, uma vez que o contrato de franquia é sempre celebrado entre uma unidade (a loja franqueada) e o próprio centro estratégico (franqueadora).

\subsubsection{Third parties}

O mecanismo de third party é pouco usado na governança da cadeia. Sua maior expressão ocorre quando a franqueadora exige que o franqueado respeite sempre um conjunto específico de leis do país, sendo que, no caso, as principais seriam: as leis trabalhistas e as de vigilância sanitária (segurança alimentar).

\footnotetext{
${ }^{82}$ Entrevista concedida pelo Executivo da Pizza Delivery. Entrevista I. [junho de 2014]. Entrevistador: Fabio Dolnikoff. São Paulo, 2014.
} 


\subsubsection{Information based networks}

O mecanismo de redes de informação foi notado no estudo, pela utilização dos comitês de trabalho como parte da tomada de inúmeras decisões.

A franqueadora implementou dois comitês de trabalho: o comitê de compras e o comitê de marketing. Em ambos os casos, a maioria dos integrantes são franqueados: no comitê de compras participam três franqueados e o sócio-diretor, e no comitê de marketing são quatro franqueados e o sócio diretor.

Os comitês têm mais um papel de consolidar uma decisão, do que tomar uma decisão de maneira conjunta. Praticamente a decisão é da franqueadora, que traz para o comitê somente as ideias que lhe convém. Apesar de não ter função real de dividir a decisão com a rede, o comitê ajuda a criar um ambiente de transparência e a difundir as decisões tomadas pela rede. A questão de transparência fica patente ao observar-se a existência de um comitê dedicado inteiramente à gestão do fundo comum, ou seja, o comitê de compras.

\subsubsection{Governança: quadro geral}

O Quadro 7, apresentado a seguir, ilustra a incidência dos mecanismos de governança do modelo de Ménard (2010) na rede Pizza Delivery.

\begin{tabular}{|c|}
\hline $\begin{array}{c}\text { Contratos } \\
\text { Relacionais }\end{array}$ \\
\hline $\mathbf{x x x x x x x}$ \\
\hline $\mathbf{x x x x x x}$ \\
\hline $\mathbf{x x x x x}$ \\
\hline $\mathbf{x x x x}$ \\
\hline $\mathbf{x x x}$ \\
\hline $\mathbf{x x}$ \\
\hline $\mathbf{x}$ \\
\hline
\end{tabular}

\begin{tabular}{|c|c|c|}
\hline $\begin{array}{c}\text { Information- } \\
\text { Based-Networks }\end{array}$ & Third Party & $\begin{array}{c}\text { Centro } \\
\text { Estratégico }\end{array}$ \\
\hline $\mathbf{x}$ & & \\
\hline \multirow[t]{2}{*}{$\mathbf{x}$} & $\mathbf{x}$ & \\
\hline & $\mathbf{x}$ & \\
\hline $\mathbf{x}$ & & $\mathbf{x}$ \\
\hline $\mathbf{x}$ & $\mathbf{x}$ & $\mathbf{x}$ \\
\hline & $\mathbf{x}$ & $\mathbf{x}$ \\
\hline & & $\mathbf{x}$ \\
\hline
\end{tabular}

Quadro 7 - Mecanismos de governança principais da Pizza Delivery Fonte: elaborado pelo autor, com base nas entrevistas 
Apesar da existência dos comitês de marketing e de compras, a classificação mais centralizadora parece ser a mais adequada à rede, devido à baixa capacidade de tomada de decisão destes comitês, além do fraco carácter relacional do acordo entre franqueados e franqueadora.

A Figura 26, apresentada a seguir, oferece uma visão da cadeia de suprimentos em que se insere a Pizza Delivery. Nesta figura pode-se observar os mecanismos de governança que regem a interação da Pizza Delivery com seus parceiros comerciais.

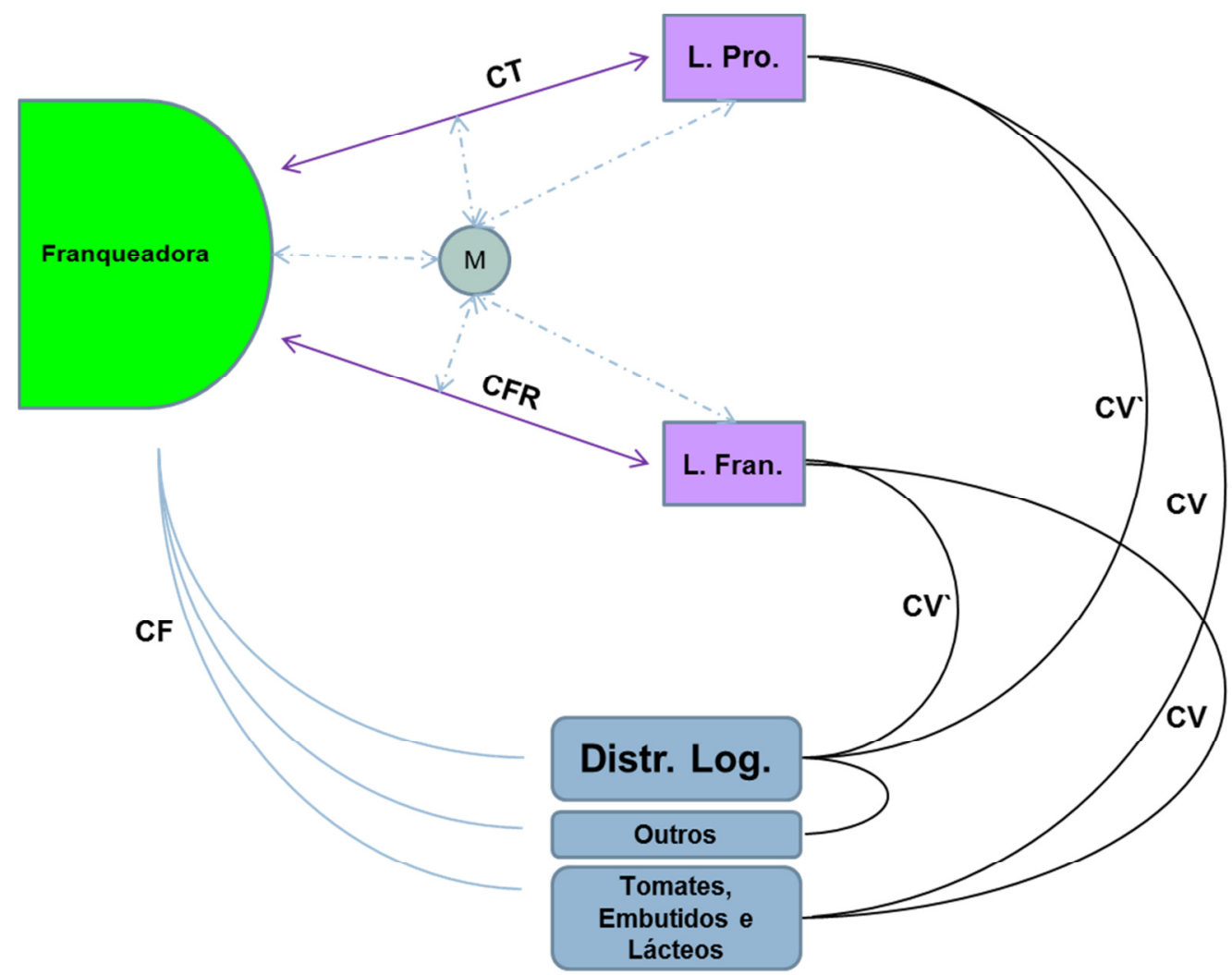

Figura 26 - Mecanismos de governança complementares associados à Pizza Delivery Fonte: elaborado pelo autor com base nas entrevistas

Sob a perspectiva da complementaridade contratual sugerida por Argyres e Liebeskind (1999), discutida na seção 7.3.2.3, vale destacar um mecanismo (complementar) de governança que parece influenciar diretamente a relação bilateral entre a franqueadora e suas lojas franqueadas. Este mecanismo é o conjunto de contratos de longo prazo para fornecimento $(\mathrm{CF})$ de matérias primas celebrado entre a franqueadora e o distribuidor logístico, assim como entre a franqueadora e alguns fornecedores, que suportam a centralização da tarefa de compras (conforme discussão apresentada na Seção 8.3). 


\subsection{Resumo do caso}

O Quadro 8, apresentado a seguir, oferece um resumo esquemático com as principais características observadas no Caso Pizza Delivery.

\begin{tabular}{|l|c|}
\hline \multicolumn{2}{|c|}{ PIZZA DELIVERY } \\
\hline $\begin{array}{l}\text { Complexidade } \\
\text { Média (indicada por uma média equipe total, de 16 profissionais em um } \\
\text { turno, por loja). }\end{array}$ \\
$\begin{array}{l}\text { Alocação de Direitos de } \\
\text { Propriedade na rede } \\
\text { (Tarefas Básicas) }\end{array}$ & $\begin{array}{l}\text { Cinco tarefas são alocadas nas lojas (produção, gerenciamento da equipe, } \\
\text { marketing de vizinhança, gerenciamento financeiro e expansão da rede). }\end{array}$ \\
\hline $\begin{array}{l}\text { Mecanismos de } \\
\text { Governança Principais } \\
\text { (Ménard, 2010) }\end{array}$ & $\begin{array}{c}\text { Centro estratégico e contrato de franquia detalhado (baixo caráter } \\
\text { relacional). }\end{array}$ \\
\hline $\begin{array}{l}\text { Mecanismos de } \\
\text { Governança } \\
\text { Complementares }\end{array}$ & $\begin{array}{c}\text { Operadora logística e contratos de longo prazo para fornecimento } \\
\text { viabilizam centralização da tarefa básica de compras. }\end{array}$ \\
\hline $\begin{array}{l}\text { Monitoramento } \\
\text { Controle Efetivo e }\end{array}$ & $\begin{array}{r}\text { a) Acompanhamento de vendas via royalties e via sistema de pedidos } \\
\text { centralizado. }\end{array}$ \\
\hline
\end{tabular}

Quadro 8 - Resumo esquemático do Caso Pizza Delivery

Fonte: elaborado pelo autor, com base nas entrevistas

Neste quadro, a Pizza Delivery foi retratada como uma cadeia de lojas em que a complexidade no ponto de venda é intermediária (uma discussão mais completa sobre a classificação da cadeia em função de sua CPV, levando em consideração as outras variáveis do constructo, além do tamanho da equipe, e uma comparação da complexidade entre as cadeias estudadas, será feita no Capítulo 11).

A governança do arranjo híbrido é feita por meio de um contrato de franquia detalhado (com baixo caráter relacional) entre a franqueadora (centro estratégico) e as lojas franqueadas. 
Cinco tarefas básicas estão alocadas na periferia da rede, sendo que os contratos de longo prazo para fornecimento de matéria prima suportam a centralização da tarefa de compras.

O monitoramento é estabelecido de várias maneiras, dentre elas: o acompanhamento das vendas via royalties, taxa de franquia e central de pedidos (alto controle efetivo), o acompanhamento das compras via distribuidor logístico (alto controle efetivo) e as vistas de inspeção (feitas em uma frequência intermediária). 


\section{O CASO CAFETERIA}

O hábito de consumo de café no Brasil é muito forte e ocorre em diversas categorias do food service nacional. Restaurantes full service oferecem café, padarias oferecem café e cafeterias encontraram no café o produto central do seu negócio.

No Brasil, as cafeterias têm uma proposta de oferecer um café de alta qualidade, tirado em máquinas especiais para café espresso, associado à oferta de outros alimentos de consumo rápido (já preparados, como por exemplo: pão de queijo), num ambiente com estrutura para consumo no local. De acordo com esta proposta, marcas como: Casa do Pão de Queijo, Rei do Mate, Café do Ponto, Santo Grão, Starbucks, Escada Café, Grão Expresso e Frans Café são concorrentes diretos.

Apesar de algumas marcas citadas terem uma linha de cafés diferenciada, e muito mais extensa que as demais, mesmo apresentando-se ao público como uma especialista em café, o hábito de consumo do brasileiro acaba colocando todas elas como concorrentes diretas. Para o consumidor brasileiro, no tocante ao café, o importante é que haja um bom expresso disponível na loja.

Outra característica do consumidor é associar o consumo do café a um momento de prazer, de indulgência. Esse tipo de hábito reforça a necessidade das cafeterias oferecerem uma estrutura de acomodação mínima para acolher o momento do consumo. Tomar um café após o almoço, ou mesmo uma simples decisão de impulso, são exemplos bem típicos do perfil de consumo ligado ao café. Outras circunstâncias também demandam a disposição de mesas e cadeiras (estrutura) para consumo no local, como o hábito de agendar uma reunião de trabalho ou um encontro social tomando um 'cafezinho'.

Uma terceira característica tipicamente brasileira associada às cafeterias é a associação do café com outros alimentos de consumo rápido, que devem estar disponíveis (prontos) no ato da compra. O pão de queijo é o principal exemplo desta série de 'salgados tipicamente brasileiros“ que são oferecidos em conjunto ao café. A Casa do Pão de Queijo é a maior cafeteria do Brasil e traz em seu nome a importância da associação de outros alimentos à 
proposta deste tipo de estabelecimento. Além de salgados, alimentos como: sucos, doces e sanduiches simples também fazem parte desta proposta.

Geralmente, quando as cafeterias ocorrem em centros comerciais como os shopping centers, as lojas posicionam-se fora das praças de alimentação ${ }^{83}$, dando preferência aos corredores de passagem, sempre oferecendo mesas e cadeiras aos seus consumidores. A opção por quiosques também é bastante comum nesta atividade, contanto que seja possível ao quiosque disponibilizar mesas e cadeiras no seu entorno para seus clientes.

O consumo de café ocorre durante o dia inteiro. Pode estar associado ao café da manhã, ao almoço ou a uma simples compra por impulso. Como a cafeína é um estimulante, a maioria das pessoas já não consome o produto à noite. Desta forma, as cafeterias acabam tendo sucesso permanecendo abertas o dia todo, pois mesmo que o café seja pouco consumido à noite, ainda restam os outros produtos a serem oferecidos aos clientes.

Em shopping centers, o pico de consumo das cafeterias ocorre entre meio dia e meia (após o almoço) e 17 horas. Para operar acompanhando o horário de funcionamento de shopping centers ou mesmo operando lojas de rua, uma cafeteria típica deve contar com dois turnos de funcionários.

\subsection{A Cafeteria}

A cafeteria estudada é uma rede de 92 lojas, que atua por todo território nacional. A estratégia organizacional adotada é a franquia, que ocorre em 100\% dos casos. Atualmente, a cadeia não conta com nenhuma loja própria. A marca é detida por uma torrefadora multinacional que também atua como fornecedora exclusiva do café às lojas. Para coordenar a rede, um escritório nacional independente da Torrefadora atua como Máster Franqueadora da marca, detendo direitos sobre todo o território nacional.

\footnotetext{
${ }^{83}$ Na exceção, como é o caso da Casa do Pão de Queijo no Shopping Ibirapuera (Cidade de São Paulo), a loja procura ficar na saída da praça.
} 
A maioria dos franqueados é mono operador. Há casos em que certos franqueados têm até quatro lojas, mas, na maioria das vezes, isso não ocorre. Hoje em dia, a cadeia conta com 52 franqueados. A rede tem suas lojas somente em centros comerciais. $80 \%$ delas ocorrem em shopping centers e os outros $20 \%$ são lojas de aeroportos e galerias comerciais.

\subsubsection{A estrutura física da loja}

As lojas geralmente contam com duas áreas: uma área de preparo e uma área de atendimento (frente de loja). As lojas são pequenas, quando comparadas a outras operações de food service. Em alguns poucos casos, o problema de espaço é tão significativo, que a loja opera sem uma área específica para o preparo.

Todas as lojas contam com uma máquina de espresso, o único equipamento sofisticado desta operação. Apesar de ser um equipamento de preparo, a máquina de café não fica na área de preparo, ficando à vista dos clientes, na área de atendimento.

A área de preparo conta com uma estrutura simples de lavagem, balcão de manipulação e preparação de alimentos, e um forno elétrico. Já a área de atendimento é estruturada em torno de um balcão onde ocorre a interação dos clientes com os atendentes, tendo como único equipamento as estufas que mantêm os salgados aquecidos.

Ressalte-se que $90 \%$ das lojas oferecem acomodação em mesas e cadeiras aos seus clientes, para consumo no local. Muitas vezes, as mesas e cadeiras são colocadas dentro e fora das lojas, avançando também pelos corredores dos shoppings.

\subsubsection{Linha de produtos}

A linha de produtos da cafeteria é praticamente aquela descrita na introdução deste capítulo. A rede se caracteriza por oferecer um número alto de blends de cafés expressos, quando 
comparada a seus concorrentes. Como uma típica cafeteria, além do café ela oferece pães de queijo e outros salgados, alguns doces, sucos, refrigerantes e sanduiches simples.

\subsection{Agentes e atores}

A seguir, serão descritos os principais atores averiguados na cadeia, seguindo a proposta apresentada no Capítulo 7, de observar separadamente a equipe interna da loja, a equipe dedicada na Máster Franquia e o franqueado.

\subsubsection{A equipe interna da loja}

Uma loja típica conta com dois tipos de funcionários: os atendentes e os assistentes de cozinha. Os assistentes atuam na área de preparo, aprontando os produtos. As principais funções dos assistentes de cozinha são: assar os salgados, preparar sucos, montar sanduiches simples e lavar as louças. Os atendentes efetivamente recebem os pedidos dos clientes e entregam os alimentos, além de manipularem a máquina de espresso. As lojas de maior movimento da rede também contam com a figura do caixa. Nas lojas de menor movimento, qualquer atendente também é capaz de receber os pagamentos.

De acordo com o movimento de cada loja, uma equipe varia em média, entre seis a nove funcionários. Este valor já considera os dois turnos de funcionamento, e também que a grande maioria das lojas fica aberta sete dias por semana, para acompanhar o andamento dos shopping centers.

Quando a equipe tem seis funcionários, um deles deve ser o assistente e os outros cinco deverão ser atendentes. Toda esta equipe é gerenciada pelo franqueado ou por um gerente profissional. Na maioria das vezes, a responsabilidade direta da equipe é do próprio franqueado. 


\subsubsection{A equipe dedicada na Máster Franquia}

A Máster Franquia coloca uma equipe de doze funcionários em dedicação exclusiva à gestão da rede. A Figura 27 apresentada a seguir, ilustra a divisão de cargos e responsabilidades entre estes profissionais.

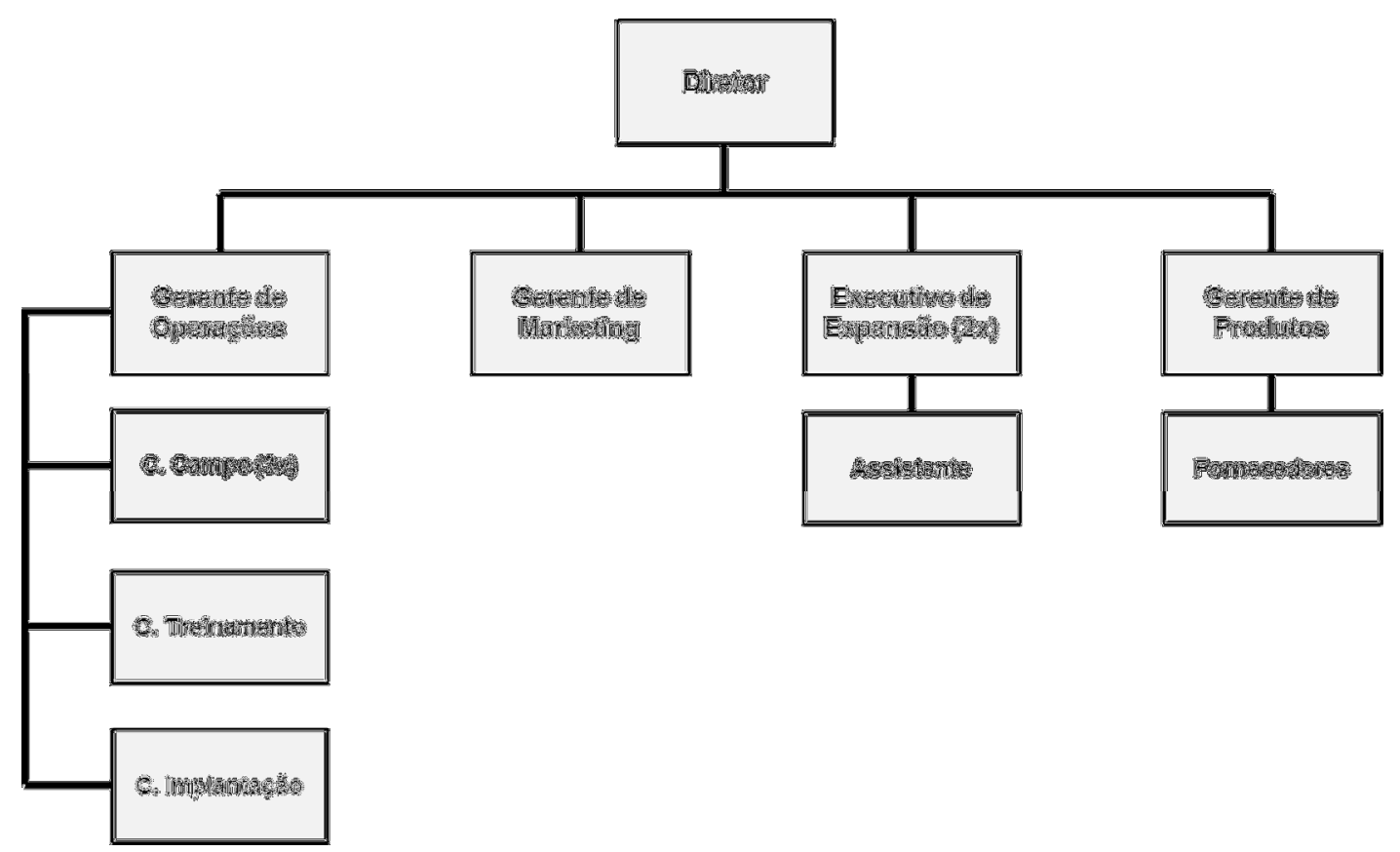

Figura 27 - A equipe dedicada na Máster Franquia da Cafeteria Fonte: elaborado pelo autor com base nas entrevistas

A área de expansão é responsável pela seleção dos pontos de venda e pela triagem dos candidatos a franqueado. Esta área, considerada a área comercial da empresa, é formada por dois executivos de expansão e um assistente. .

A área de operações é responsável por todo apoio no dia a dia dado às lojas. Nessa área, atuam três consultores de campo que se dividem por território de atuação. O primeiro deles atende as lojas de São Paulo e interior deste estado, o segundo consultor atende às regiões norte e nordeste do País e o último atende à região sul. 
A área de operações também mantem um consultor dedicado exclusivamente ao processo de implantação de lojas novas e um consultor dedicado inteiramente ao treinamento dos funcionários da rede.

A área de marketing é responsável pelo desenvolvimento das campanhas anuais da cadeia e pelo desenvolvimento de todo material de marketing de ponto de venda que será usado pela rede. Para estes desenvolvimentos, a empresa conta com o apoio de uma agência de propaganda.

A área de produtos dedica-se ao desenvolvimento de toda linha de produtos oferecida nas lojas, exceto os cafés. Para tanto, a empresa conta com o apoio de uma empresa de nutrição e segurança alimentar. Ainda na área de produtos, um profissional dedica-se ao desenvolvimento dos fornecedores da rede. Deve-se esclarecer que a matriz, a Indústria de Torrefação dona da marca, cuida da gerência institucional da marca e dos desenvolvimentos ligados ao produto café.

\subsubsection{O franqueado}

Em termos contratuais, o franqueado deve se comprometer a operar sua loja e ser o sócio majoritário da franquia, detendo pelo menos $51 \%$ das cotas da empresa. No contrato de franquia, o franqueado é indicado como 'Intuito Persona', ou seja, o indivíduo que deve operar o negócio.

O entrevistado diz que, na prática, os franqueados acabam tendo dois tipos básicos de comportamento em relação à dedicação ao negócio:

De $30 \%$ a $40 \%$ dos franqueados dedicam-se integralmente ao negócio no primeiro ano da operação. A partir do segundo ano, eles passam a dedicar de seis a oito horas por dia no empreendimento. Estes são os franqueados mais dedicados e este perfil de dedicação é mais encontrado nos casos que o franqueado possui mais de uma loja da rede. 
Um segundo perfil de dedicação é aquele em que o franqueado dedica de quatro a cinco horas ao negócio no primeiro ano de operação. A partir do segundo ano, ele passa a dedicar-se aproximadamente duas horas por dia, sendo comum a presença do franqueado na abertura e fechamento da loja. Entre $60 \%$ a $70 \%$ dos franqueados da rede têm este comportamento e são em sua maioria mono operadores.

O entrevistado fez questão de frisar que a visão da Máster Franquia é de que a gestão do negócio é muito mais eficiente (em termos operacionais e em termos de lucratividade) quando o franqueado realmente dedica-se ao negócio. Para a Máster Franquia, que percebe a relação direta entre o número de horas dedicadas ao negócio e o número de lojas de um franqueado, o perfil ideal do franqueado é aquele que chega a ter de três a quatro lojas.

Para operar uma loja adequadamente, o franqueado deve se envolver em duas atividades principais: a gestão de sua equipe e a atividade de compras. Em relação à equipe, como em qualquer outro negócio de food service, o turn over é alto. No caso da Cafeteria, ele é de $100 \%$ ao ano. Esta situação requer uma disposição e capacitação do franqueado para treinar continuamente sua equipe e cuidar de questões burocráticas ligadas a contratações e demissões.

As compras na rede não são centralizadas, nem existe a presença de um operador logístico. Os fornecedores são todos previamente aprovados pela Máster Franquia e o dia a dia das compras deve ser levado pelo franqueado. O entrevistado fez questão de frisar que, apesar dos descontos para a rede serem negociados pela Máster Franquia, uma boa gestão das compras por parte do franqueado consegue auferir certos ganhos também, ou seja, nesta rede as compras não são simplesmente um processo de colocação de pedidos.

Em relação às compras, o entrevistado comenta que um franqueado pode conseguir programar suas compras concentrando-se em um número menor de fornecedores e conseguir um preço ainda melhor. Em alguns casos, o franqueado pode conseguir descontos maiores concentrando suas compras em determinados períodos do mês. Em ambos os casos, percebe-se que existem ações importantes que cabem ao franqueado que podem vir a ser significativas na lucratividade de sua unidade, no que se refere ao processo de compras. 


\subsubsection{O processo de escolha do franqueado}

A Máster Franquia utiliza uma consultoria em RH para auxiliá-la a identificar o candidato ideal. Baseada em sua larga experiência, a Máster Franquia conseguiu identificar alguns perfis pessoais humanos adequados para vir a ser um franqueado de sucesso para esta rede. A Máster Franquia define estes perfis com a consultoria em RH, e esta, por sua vez, aplica uma série de testes comportamentais nos candidatos para ajudar no processo de triagem. Além de trabalhar fortemente a triagem do perfil do candidato, a Máster Franquia também faz uma avaliação financeira do candidato, para saber se ele efetivamente tem o capital necessário para vir a ser um franqueado.

A Máster Franquia desvinculou a escolha do franqueado à escolha específica do ponto comercial. Para ela, a escolha do franqueado é feita em função de um território, que, geralmente, é todo um shopping center. Após a triagem, e a definição do território, a Máster Franquia celebra um pré-contrato de franquia com um candidato escolhido, quando o ponto comercial ainda não foi efetivamente escolhido. Se o ponto de venda já está escolhido é celebrado o contrato definitivo, sem haver necessidade de haver um pré-contrato.

\subsection{Atividades, responsabilidades e tarefas}

A seguir, serão descritas as principais tarefas averiguadas na cadeia e sua alocação.

\subsubsection{O desenvolvimento dos produtos}

Na perspectiva do ponto de venda, o desenvolvimento de produtos e totalmente centralizado. Os desenvolvimentos dos cafés são comandados pela Torrefadora. Nem a loja, nem a Máster Franquia chegam a participar deste processo. Uma equipe interna da Torrefadora detém todos os direitos de decisão sobre este processo. Todos os outros produtos são desenvolvidos pela 
Máster Franquia, por sua área de produtos, conforme explicado anteriormente na Seção 10.2.2. Os novos produtos geralmente são lançados junto das campanhas anuais da rede.

Há um Comitê de Produtos na rede, formado por aproximadamente cinco franqueados e a Máster Franquia. Este fórum de discussão é verdadeiramente usado na captação de ideias e insights para os desenvolvimentos da rede. Apesar de o comitê ser consultivo e a Máster Franquia deter todos os direitos de decisão do fórum, na prática ele acaba sendo uma ótima ferramenta de captação de informação para a área de produtos da Máster Franquia.

\subsubsection{O desenvolvimento e veiculação de promoções e propaganda}

O desenvolvimento de promoções e propaganda é mais uma atividade centralizada na rede. Duas vezes por ano, no início do verão e início do inverno, a Máster Franquia promove suas campanhas coletivas pela rede. Contratualmente todas as lojas são obrigadas a aderir a estas campanhas.

A área de marketing da Máster Franqueadora, apoiada por uma agência de publicidade (que não é a mesma agência da Torrefadora), desenvolve os conceitos que serão trabalhados nas campanhas, inclui os lançamentos dos produtos sendo desenvolvido pela área de produtos e desenvolve todo o material de propaganda no ponto de venda que deverá ser usado pelas lojas durante a campanha. Vale frisar que a taxa de propaganda paga mensalmente pelas lojas deve cobrir exatamente este custo: desenvolver as campanhas e peças promocionais.

No caso dos assuntos ligados às campanhas e propaganda no ponto de venda, também existe um fórum de discussão do tipo comitê de trabalho. Novamente, o comitê tem caráter consultivo e todo direito de decisão está alocado na Máster Franquia. Após concluído o desenvolvimento destas peças, a responsabilidade de produzir e veicular o material promocional é toda das lojas. O desenvolvimento e a veiculação de campanhas institucionais dedicadas à marca do café e da rede de cafeterias são feitas pela Torrefadora. Nem as lojas da rede, nem a Máster Franquia participam desta tarefa e até a agência de propaganda utilizada não é a mesma que a Máster Franquia costuma usar. 


\subsubsection{A expansão da rede e a escolha do ponto comercial}

Como a atuação da rede é focada em shopping centers, a expansão acompanha a forma com que este tipo de estabelecimento costuma comercializar suas lojas, ou seja, antecipadamente. As empresas responsáveis pelo levantamento de novos shopping centers costumam procurar a Máster Franquia para oferecer os pontos adequados a cafeterias bem antes de o shopping ser inaugurado. Nesse processo, a Máster Franquia costuma reservar um ponto que lhe pareça promissor e depois encontrar o franqueado adequado para a futura loja.

No caso de shoppings que já estão operando, o processo é parecido. As administradoras procuram a Máster Franquia e oferecem algum ponto que tenha fica vago recentemente. Em ambos os casos, a decisão final do local e a negociação não cabem ao franqueado. A ele cabe aceitar ou não a proposta, assinando o contrato de locação com o shopping center. Apesar de menos comum, ainda ocorrem casos em que um candidato identifica um ponto comercial e traz a ideia para a Máster Franquia, que aceita avaliar a possibilidade de bom grado.

Quanto ao processo de reforma do ponto para a montagem da loja, a Máster Franquia fornece toda sorte de informações para a reforma da loja, mas não chega a gerenciá-la como faz a Pizza Delivery estudada no capítulo anterior.

\subsubsection{Precificação}

A precificação final do produto é acordada numa banda de mais ou menos $20 \%$, em que o franqueado ajusta seu preço final, conforme achar mais conveniente. Esta banda, duas vezes maior que a utilizada na Hamburgeria, faz com que esta decisão se influenciada efetivamente pelo franqueado.

\subsubsection{Definição do mix de produtos da loja}

Contratualmente todo e qualquer franqueado deve oferecer a linha completa definida pela Máster Franquia em suas lojas, inclusive todos os blends de café. Como a linha não é uma das 
mais extensas, o que já era esperado em se tratando de uma típica cafeteria, não chega a ser algo difícil a ser comprido pelo franqueado.

A Máster Franquia não se apresenta impermeável à ideia de haver algo regional em certas lojas. Apesar de ser algo pouco frequente, um franqueado pode submeter uma solicitação de interesse em incluir algum produto específico para avaliação da Máster Franquia. Em alguns casos, a Máster Franquia avalia a ideia positivamente e, após avaliar também o eventual fornecedor deste novo produto, permite que o franqueado tenha algo específico em sua loja.

\subsubsection{Atividade de compras}

$\mathrm{O}$ acordo (contrato de franquia) entre franqueados e Máster Franquia determina que os franqueados deverão comprar apenas de fornecedores homologados pela Máster Franquia. A área de fornecedores da Máster Franquia dedica-se a desenvolver os fornecedores da rede, basicamente: avaliando a qualidade de seus produtos, e negociando o desconto a ser dado para toda e qualquer loja da cafeteria que vier a comprar de um fornecedor homologado.

A Máster Franquia procura homologar o menor número de fornecedores por item de compra, para obter o maior desconto possível, concentrando seu poder de compra, mas não faz dessa ação uma política irrevogável. Em alguns casos, a própria questão logística inviabiliza a compra devido à distância. Quando tal fato ocorre, a Máster Franquia homologa outro fornecedor, para que as lojas permaneçam competitivas.

Conforme abordado anteriormente, a participação do franqueado nesse processo é importante. O gerenciamento das comprar de cada loja cabe ao franqueado e a eficiência desta operação depende da dedicação dele, pois em alguns casos existe margem de negociação com os fornecedores.

O entrevistado comenta que um franqueado pode conseguir programar suas compras concentrando-se em um número menor de fornecedores e conseguir um preço ainda melhor. Em alguns casos, o franqueado pode conseguir descontos maiores concentrando suas compras em determinados períodos do mês. Em ambos os casos, percebe-se que existem ações 
importantes que cabem ao franqueado, que podem vir a ser significativas na lucratividade de sua unidade, no que se refere ao processo de compras.

Diferente de outras redes de food service, em que o processo de compra fica restrito à colocação de pedidos é feita por um gerente ou membro da equipe interna, na rede da Cafeteria esta tarefa está bastante alocada nas responsabilidades do franqueado.

Deve-se salientar que a relação da rede com o fornecedor de café é muito diferente, pois a compra deste item é compulsória e não há qualquer negociação envolvida neste processo, apenas a negociação inicial entre Máster Franquia e Torrefadora, ocorrida no momento da designação da Máster Franquia.

\subsubsection{Uso de sistemas de gestão no restaurante}

As lojas da Cafeteriam utilizam um sistema eletrônico simples de gestão do caixa e estoques da loja. O processo de adoção deste sistema foi totalmente decidido pela Máster Franquia.

\subsubsection{Formação e gerenciamento de equipe}

A Máster Franquia e o franqueado têm atuação decisiva no que diz respeito à formação e gerenciamento da equipe da loja. A franqueadora responsabiliza-se por todo treinamento da equipe de uma loja nova. Nesses casos, é oferecido ao franqueado e à sua equipe um treinamento intensivo de sete dias, sobre todas as rotinas operacionais de uma loja, além de módulos gerenciais ao franqueado. Este processo é gerenciado pela área de treinamento da Máster Franquia. A área de implantação da Máster Franquia também atua nesse momento, oferecendo apoio e a presença do gerente de implantação para o novo projeto, pelos cinco dias que caracterizam a inauguração de uma nova loja.

Após a inauguração, a área de treinamento mantém o vínculo de apoio ao franqueado

oferecendo acesso a uma plataforma digital desenvolvida especialmente o para treinamento da 
equipe no dia a dia, além de oferecer outros materiais de treinamento. A consultoria de campo também atua neste sentido, dando apoio ao franqueado no gerenciamento de sua equipe.

Apesar de todo o apoio oferecido pela Máster Franquia, o desafio diário de manter a equipe da loja treinada e motivada é do franqueado. Como comentado anteriormente, o gerenciamento da equipe é a atividade que mais toma tempo do franqueado no cuidado com sua loja. A responsabilidade e a palavra final na contratação da equipe são do franqueado. A responsabilidade pelo sucesso dos treinamentos aplicados para manter, também, o nível da equipe após a fase de inauguração.

\subsubsection{Gerenciamento financeiro}

A responsabilidade de gerir o fluxo de caixa de uma loja da rede é inteiramente do

franqueado. É necessária bastante atenção para gerir o pagamento de fornecedores e funcionários. No caso da Cafeteria, esta tarefa fica um pouco atenuada em comparação com outras cadeias de food service, por se tratarem de poucos itens e poucos funcionários por loja.

\subsubsection{Alocação dos direitos de decisão: quadro geral}

A Figura 28, apresentada a seguir, ilustra a alocação típica de direitos de propriedade da Cafeteria. Observa-se que, comparativamente, observando apenas a alocação de tarefas, a Cafeteria tem a maior gama de tarefas descentralizadas quando comparada aos casos da Hamburgeria e da Pizza Delivery.

No caso da Cafeteria, a expansão da rede e escolha do ponto comercial, o processo de compras, o gerenciamento da equipe e o gerenciamento financeiro da loja dependem do franqueado. Apesar de ter sido dito que existe alguma tolerância por parte da Máster franquia em relação a solicitações de lojas para incluir produtos regionais específicos, este tipo de caso é pouco frequente e não merece ser representado no Quadro Geral de Alocação de Tarefas como uma tarefa descentralizada. 
Master Franquia

Franquia

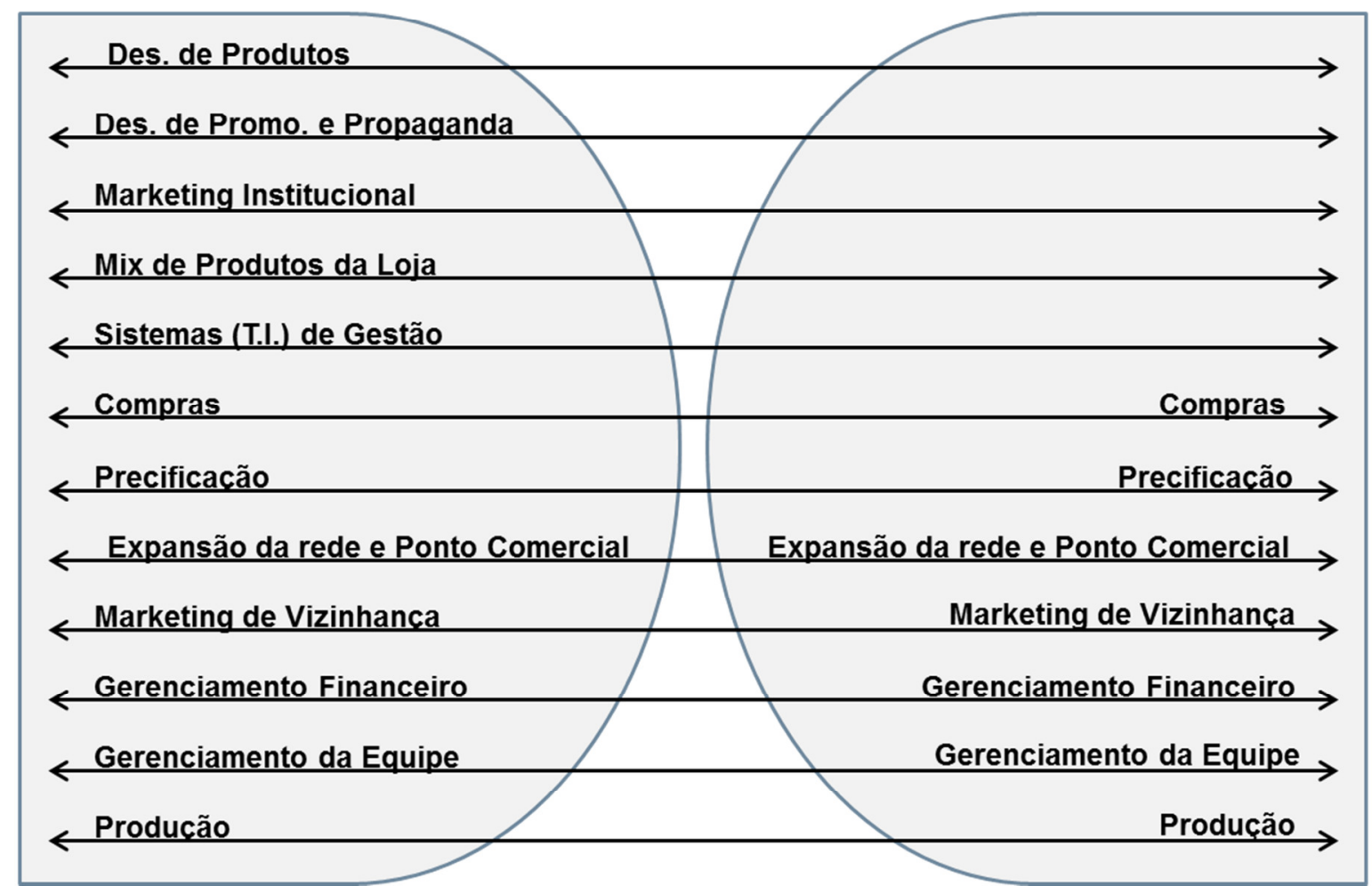

Figura 28 - Alocação dos direitos de decisão na Cafeteria (quadro geral)

Fonte: elaborado pelo autor com base nas entrevistas

\subsection{Complexidade}

Conforme a proposta de pesquisa apresentada no Capítulo 7, a Complexidade é analisada a partir de seu caráter fabril (manipulação) e de seu caráter de serviços (atendimento). O caráter fabril é determinado pela extensão das etapas do processo produtivo, pela intensidade tecnológica adotada, pela aderência ao uso de rotinas, pelo volume de produção e nível de qualidade dos alimentos produzidos e pelo tamanho da equipe envolvida neste processo.

O caráter de serviços do constructo é determinado pela extensão do atendimento, pela estrutura deste atendimento, pelo volume de clientes atendidos no restaurante a certo nível de atenção (qualidade do atendimento) e pelo tamanho da equipe envolvida nessa atividade. A seguir, cada uma destas dimensões referentes ã Pizza Delivery é observada em detalhes. 


\subsubsection{Etapas}

Entre as operações de food service, as cafeterias são uma proposta que procura operar de maneira simples, efetivamente transformando os alimentos o menos possível. A maioria das operações se resume a esquentar um salgado, servir uma bebida pronta ou tirar um café. $\mathrm{O}$ que caracteriza a linha de produtos oferecidos pela Cafeteria é uma necessidade de manipulação baixa, visto que os produtos praticamente não sofrem um tratamento culinário na loja.

Os produtos não são porcionados na loja. Quando há necessidade de se usar algo porcionado, este item já é encomendado fracionado, como por exemplo, o presunto usado nos sanduíches, o qual já vem fatiado. Na maioria das vezes, o que há em termos de processo culinário é esquentar determinado produto, como por exemplo: assar o pão de queijo em fornos elétricos. Observa-se que $90 \%$ dos pedidos da Cafeteria são de: café acompanhado de um salgado. Somente os outros $10 \%$ têm alguma manipulação (ex: montagem de sanduiche) envolvida. Neste escopo, o número de etapas do processo produtivo é sempre baixo.

\subsubsection{A intensidade técnica do preparo}

A intensidade técnica do preparo é média.

A máquina de espresso é um item tecnologicamente sofisticado e sua utilização requer treinamento específico. Mesmo assim, este item isolado não chega a caracterizar a loja como uma operação de perfil tecnológico marcante, e a baixa diversidade de produtos derivados da máquina, basicamente algumas poucas variações do café espresso, contribuem para diminuir o impacto deste item no agregado do carácter de tecnificação da loja. Contando o caráter tecnificado da máquina de espresso e a baixa tecnificação geral dos outros processos, parece razoável classificar a tecnificação geral de uma loja da Cafeteria como intermediária. 


\subsubsection{Rotinas}

A adesão às rotinas é intermediária. As rotinas são definidas pela Máster Franquia e devem ser adotadas pelas lojas, mas deve-se notar que o número de processos é menor do que a média das lojas que se dedicam ao food service, o que atenua esta característica. Outro fator que atenua o carácter de utilização de rotinas é a própria superficialidade das rotinas em questão. Na Cafeteria, a maioria dos processos é simples o que exige rotinas pouco detalhadas. O principal processo culinário de uma cafeteria é a preparação do café, que, na Cafeteria estudada, há uma série de rotinas bem definidas pela Máster Franquia a serem seguidas. Mesmo assim, a presença da máquina de espresso na loja diminui bastante o desafio humano a ser enfrentado, porque a simplificação do processo advinda da utilização desta máquina faz das rotinas algo de fácil assimilação.

\subsubsection{Volume de produção}

O volume de produção pode ser caracterizado como baixo. O volume propriamente dito de material produzido é baixo, utilizando um número de itens produtivos bastante baixo, conforme discutido anteriormente. A loja vende café e salgado, não vende refeições completas. Como foi apresentadoanteriormente, $90 \%$ dos pedidos da Cafeteria são de um café acompanhado de um salgado.

\subsubsection{Nível do produto}

Apesar de a Cafeteria ter uma linha de cafés muito mais sofisticada que seus concorrentes, dois motivos sugerem que a qualidade percebida pelos consumidores seja intermediária: em primeiro lugar, conforme discutido no início deste capítulo, o perfil de consumo do brasileiro não é sensível a este tipo de diferenciação, fazendo de cafeterias mais e menos sofisticadas, concorrentes diretas; em segundo lugar, todos os outros produtos têm uma sofisticação intermediária. Nenhuma cafeteria se propõe a oferecer o que há de mais sofisticado em seus doces e salgados para seus clientes, visto que não é a proposta deste tipo de estabelecimento. 


\subsubsection{Equipe de produção}

A equipe de produção de uma típica loja da Cafeteria é realmente baixa. Conforme disposto na Seção 10.2.1, dedicada à caracterização da Equipe Interna da Loja, os assistentes de cozinha são os responsáveis pelo que se pode chamar de área de produção de uma cafeteria. Em números absolutos, para uma equipe completa de loja, que varia entre seis e nove profissionais, iremos encontrar de um a dois assistentes de cozinha. Esta relação de quatro vezes mais atendente do que assistentes de cozinha é um reflexo da baixa complexidade do processo produtivo da cafeteria, além de ser resultado da alocação do processo de utilização da máquina de café na área de atendimento.

\subsubsection{Extensão do atendimento}

A extensão do atendimento é intermediária. O pagamento é feito no ato do pedido e não há mais interação pessoal significativa dos atendentes com os clientes durante o ato do consumo, que é feito nas dependências da loja. Como no caso da Hamburgeria, a extensão é intermediária.

\subsubsection{Estrutura de atendimento}

A estrutura de atendimento pode ser classificada como intermediária. Apesar de não haver o acompanhamento do consumo, a grande maioria (90\%) das lojas oferece um local reservado para o cliente apreciar seu café ou fazer um lanche simples. Na prática, a Cafeteria, assim como a maioria de suas concorrentes que operam em shopping centers, oferece um conjunto de mesas e cadeiras para que seus consumidores possam usar, durante o ato do consumo. Sem dúvida é um conjunto pequeno, que varia de cinco a dez mesas por loja, acompanhadas por suas respectivas cadeiras. 
A sofisticação do mobiliário é moderada, deixando à privacidade oferecida aos consumidores o posto de característica de maior valor, por se tratar de uma área reservada dentro do shopping. Deve-se lembrar de que a maioria das lojas de food service que operam em shoopings oferecem apenas as dependências das praças de alimentação para seus clientes.

\subsubsection{Volume do atendimento}

O volume de clientes atendidos é intermediário. As lojas geralmente têm seu pico de demanda após o almoço e o período da tarde é geralmente mais forte que o da manhã e o da noite. Apesar das variações, o que caracteriza o atendimento é um fluxo baixo, porém constante que, no cômputo geral de dois períodos em que a loja permanece aberta, chega a ser significativo, podendo ser classificado como intermediário.

\subsubsection{Nível do atendimento}

O nível do atendimento é intermediário e se assemelha muito ao nível básico da maioria das cadeias de fast food. A descrição feita sobre o nível de atendimento no caso da Hamburgeria encaixa-se bem a este caso também, em que as principais características do serviço oferecido são: rapidez, cordialidade e superficialidade.

\subsubsection{A Equipe de atendimento}

Apesar de a equipe de atendimento ser maior que a equipe de produção, deve-se perceber que em números absolutos o número continua sendo pequeno em comparação às equipes de outras cadeias de food service. 


\subsubsection{Complexidade: quadro geral}

A seguir, conforme ilustra a Figura 29, será retomado o quadro completo do constructo de complexidade no ponto de venda, com o intuito de incluir na figura as informações observadas sobre o caso específico da Cafeteria.

As entrevistas revelaram que entre todos os itens que formam o constructo, o entrevistado indicou o número total da equipe como sendo o de maior impacto sobre a complexidade no ponto de venda. Quanto aos outros itens, não houve indicação que pudesse levar a uma ponderação de seus impactos. Notou-se que a visão do entrevistado estava alinhada ao que foi discutido na entrevista da Hamburgeria.

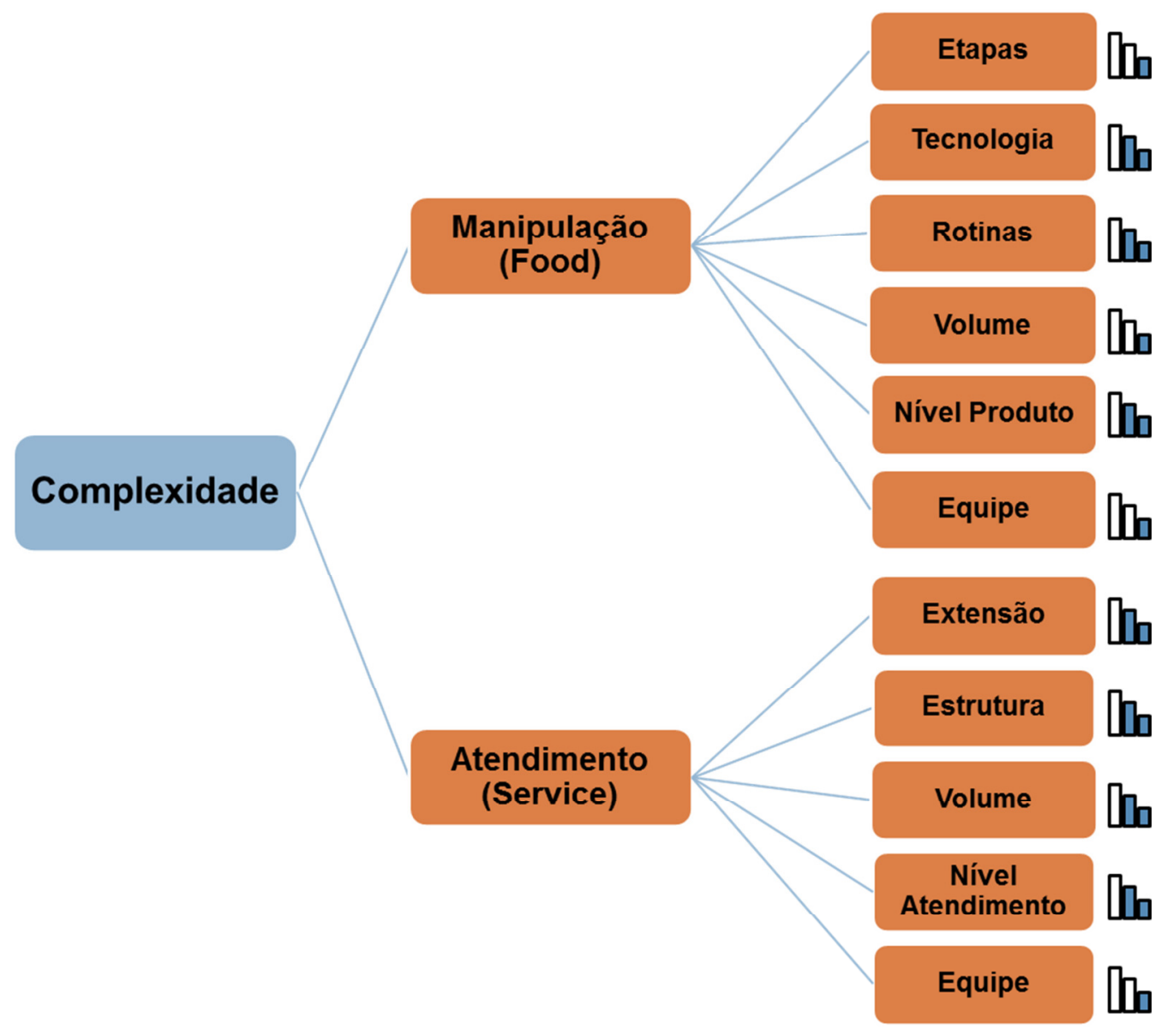

Figura 29 - A complexidade no ponto de venda da Cafeteria

Fonte: elaborado pelo autor com base nas entrevistas 


\subsection{A Governança da relação entre a Máster Franqueadora e suas lojas}

Utilizando o modelo de Ménard (2010) como estrutura de análise da governança na relação entre uma máster franqueadora e suas lojas, será apresentada a seguir uma discussão sobre como cada um dos quatro mecanismos apontados pelo autor ocorre na Cafeteria, detalhando a relação entre Máster Franqueadora \& Lojas Franqueadas.

\subsubsection{O Contrato de franquia}

No caso da Cafeteria, obteve-se acesso ao modelo de contrato padrão entre Máster Franquia e Loja Franqueada. Somente foi possível fazer uma leitura do contrato, não havendo possibilidade de publicar uma cópia deste documento nos anexos deste trabalho. Vale comentar que este modelo é aplicado em todos os casos da rede, não havendo variação da estrutura do contrato de acordo com qualquer eventual peculiaridade de um novo franqueado.

Observou-se que o contrato de franquia da Cafeteria também segue um padrão próximo ao da Pizza Delivery e da Hamburgeria. Também é um contrato bastante completo. Novamente, a intenção do desenho contratual é deixar poucas possibilidades de renegociação para o futuro.

Referente às obrigações assumidas no contrato, o franqueado compromete-se com o pagamento de royalties, taxa de propaganda e adesão ao sistema da rede. A adesão à rede é formalizada pelo pagamento da taxa de franquia e pelo compromisso assumido em seguir o Manual do Franqueado.

O compromisso da Máster Franquia é permitir o uso da marca ao franqueado em determinada região geográfica e aceitá-lo como usuário de seu sistema. Para garantir o cumprimento do contrato de franquia, alguns mecanismos são utilizados, conforme detalhamento apresentado a seguir. 


\subsubsection{Manual e treinamento}

$\mathrm{Na}$ visão do entrevistado, o manual da Cafeteria é uma peça bastante completa. Em comparação aos manuais de suas concorrentes diretas, ele acredita ser um dos mais bem feitos, pois acredita na importância deste instrumento e fez o investimento necessário para tanto. Não fugindo ao padrão, o manual detalha todas as rotinas que o franqueado deve seguir para acompanhar o Sistema preconizado pela Máster Franqueadora. Novamente, o próprio manual impõe uma série de treinamentos para melhorar a aderência do franqueado e sua equipe às rotinas que contém.

Conforme comentado anteriormente, o treinamento da fase de inauguração e todo treinamento de manutenção trazido pelos consultores de campo e pelo consultor de treinamento atuam no sentido de fixar o conhecimento contido no manual ao dia a dia de cada loja. Outros mecanismos estão mais preocupados com a faceta da diminuição do oportunismo e focam o monitoramento dos agentes e a punição ao descumprimento contratual. Este tipo de preocupação parece ser o mote da relação Máster Franquia e Lojas Franqueadas. A seguir, são apresentados os casos mais relevantes.

\subsubsection{Inspeções formais via equipe de operações}

As inspeções formais são uma prática na rede da Cafeteria e os consultores de campo visitam as lojas uma vez a cada 45 dias. As visitas têm dois caráteres: um consultivo e outro de monitoramento. Para um bom aproveitamento da visita, os consultores tentam identificar pontos que devem melhorados na operação da loja, observando e repassando com o franqueado as rotinas do Sistema. Os consultores também acabam trazendo material de treinamento ou qualquer nova informação que a Máster Franqueadora esteja disseminando no momento, reforçando a comunicação interna na rede. Além do caráter consultivo, as visitas também geram relatórios sobre a forma como a loja está sendo operada, o que mostra o caráter de monitoramento deste tipo de contato. 


\subsubsection{Inspeção informal via equipe de operações}

A equipe de operações está sempre disponível para orientar o franqueado de forma remota. Adicionalmente, as consultas esporádicas dos franqueados aos consultores de campo e ao consultor de treinamento também geral uma possibilidade informal da Máster Franquia monitorar suas lojas.

\subsubsection{Atenção da equipe de operações como medida de performance da franqueadora para franqueados}

Os franqueados utilizam este tipo de medida, mesmo que subjetiva, para avaliar o apoio dado pela Máster Franquia ao seu negócio. No caso da Cafeteria, a visita de campo ocorre apenas uma vez a cada 45 dias. Esta frequência é mais baixa que a da Hamburgueria e da Pizza Delivery, porém está na média das redes de cafeteria, como comentou o entrevistado.

\subsubsection{Mistery Shopper}

Esta ferramenta é usada pela Máster Franquia pelo menos duas vezes por ano em todas as lojas. O comprador misterioso da Cafeteria preocupa-se em observar: se a loja visitada emite nota fiscal, se a comunicação visual está sendo respeitada, se o atendimento foi cortês e educado e até mesmo se o pão de queijo estava quente e se o café foi bem tirado. Uma empresa terceirizada é contratada para aplicar esta ferramenta para a Máster Franquia, que não se propõe a gerenciar este processo sozinha. Em casos de suspeita de fraude, a Máster Franquia também utiliza essa ferramenta pontualmente, para avaliar um franqueado duvidoso no cumprimento de suas obrigações com o sistema. 


\subsubsection{Acompanhamento do fluxo de compras}

A Máster Franquia tem acesso a todo fluxo de compras das lojas. Dois acordos são responsáveis por manter esse fluxo de informação: em primeiro lugar um fornecedor só é homologado se tiver o compromisso de mandar periodicamente um relatório das compras de todas as lojas da rede. Em segundo, os franquiados que aderem ao Sistema se comprometem a comprar apenas de fornecedores homologados. Vale comentar que este tipo de acompanhamento tem todo mérito, mas não é tão eficiente quanto centralizar as compras numa distribuidora logística, ou adotar um sistema aberto on line para pedidos de compras. Estas outras formas trazem uma informação de melhor qualidade.

\subsubsection{Monitoramento via acompanhamento de vendas}

Todas as lojas fornecem diariamente, via sistema eletrônico, a informação do que foi vendido no dia, após o fechamento do caixa. Ademais, a cada três meses cada loja franqueada deve apresentar um relatório de suas vendas à franqueadora.

\subsubsection{Monitoramento via taxa de royalties}

Este indicativo mensal de faturamento também permite à franqueadora monitorar suas lojas quanto ao volume de vendas.

\subsubsection{Monitoramento do esforço da franqueadora via elaboração de campanhas}

Assim como em outras redes, os franqueados da Cafeteria assim o fazem: avaliam o esforço da franqueadora por intermédio da performance das campanhas coletivas propostas ao longo do ano e do material promocional desenvolvido. 


\subsubsection{Cultura interna como mecanismo de enforcement}

No caso da Cafeteria, não se detectou nenhum esforço específico da Máster Franquia em trabalhar uma cultura interna forte.

\subsubsection{O caráter relacional do contrato}

Acompanhando os outros casos apresentados neste trabalho, a Cafeteria também apresenta um caráter relacional muito baixo na relação entre Máster Franquia e Franqueado. Percebe-se que o franqueado deste caso também adota uma posição de seguidor, não tendo qualquer expectativa de influenciar as eventuais decisões da rede no futuro.

\subsubsection{O centro estratégico}

Assemelhando-se aos outros casos estudados, a figura do centro estratégico forte (centralizador) assumida pela Máster Franqueadora é o mecanismo que mais caracteriza este arranjo. No caso da Cafeteria, vale ressaltar que a Torrefadora que detém os direitos da marca influencia pouco o dia a dia da rede. Sua participação é mais caracterizada como a de um fornecedor exclusivo que atende a rede do que como uma matriz.

Esta distância vai além de uma baixa influência da Torrefadora sobre a rede, pois na prática as rotinas e o sistema da rede não são desenvolvidos e modificados pela matriz e depois acolhidos pela Máster Franquia como no caso da Hamburgeria. No caso da Cafeteria, o Sistema de Franquia fica totalmente por conta da Máster Franquia. 


\subsubsection{Third parties}

O mecanismo de third party também é pouco usado na governança desta cadeia. Assim como nos outros casos estudados, sua maior expressão acontece no momento em que a Máster Franqueadora exige que o Franqueado respeite sempre um conjunto específico de leis do país em que atua, no caso, as principais seriam: as leis trabalhistas e as de vigilância sanitária (segurança alimentar). Uma peculiaridade observada no caso da Cafeteria foi a inclusão do Código de Ética da ABF no hall de códigos a serem respeitados pelos franqueados, exigidos pela Máster Franquia. Essa observação somente foi possível, porque, neste caso, o contrato de franquia foi efetivamente lido. De qualquer forma, dentro do contexto do caso, em nenhum momento esta peculiaridade mostrou-se significativa, conduzindo à mesma conclusão de que as third parties têm pouco peso na governança da relação entre máster franquia e franqueados.

\subsubsection{Information based networks}

Quanto às information based networks, dois representantes desta classe de mecanismo de governança foram observados: o comitê de marketing e o comitê de compras. Como nas outras redes de food service em foco neste trabalho, também se constatou apenas o caráter consultivo nestes fóruns de discussão. Novamente, o Centro Estratégico (Máster Franquia) detém todo poder de decisão destes grupos de trabalho. 


\subsubsection{Governança: quadro geral}

O Quadro 9, apresentado a seguir, ilustra a incidência dos mecanismos de governança do modelo de Ménard (2010) na rede da Cafeteria.

\begin{tabular}{|c|}
\hline $\begin{array}{c}\text { Contratos } \\
\text { Relacionais }\end{array}$ \\
\hline $\mathbf{x x x x x x x}$ \\
\hline $\mathbf{x x x x x x}$ \\
\hline $\mathbf{x x x x x}$ \\
\hline $\mathbf{x x x x}$ \\
\hline $\mathbf{x x x}$ \\
\hline $\mathbf{x x}$ \\
\hline $\mathbf{x}$ \\
\hline
\end{tabular}

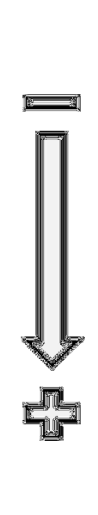

\begin{tabular}{|c|c|c|}
\hline $\begin{array}{c}\text { Information- } \\
\text { Based-Networks }\end{array}$ & Third Party & $\begin{array}{c}\text { Centro } \\
\text { Estratégico }\end{array}$ \\
\hline $\mathbf{x}$ & $\mathbf{x}$ & \\
\hline $\mathbf{x}$ & $\mathbf{x}$ & \\
\hline $\mathbf{x}$ & & $\mathbf{x}$ \\
\hline $\mathbf{x}$ & $\mathbf{x}$ & $\mathbf{x}$ \\
\hline & $\mathbf{x}$ & $\mathbf{x}$ \\
\hline & & $\mathbf{x}$ \\
\hline
\end{tabular}

Quadro 9 - Mecanismos de governança principais da Cafeteria

Fonte: elaborado pelo autor, com base nas entrevistas

Apesar de o Comitê de Produtos ter sido apontado como um importante provedor de informações e ideias provenientes das lojas para a máster franquia, seu caráter puramente consultivo sugere que a mesma classificação centralizada apontada no caso da Hamburgeria e no caso da Pizza Delivery seja usada também. 
A Figura 30, apresentada a seguir, oferece uma visão da cadeia de suprimentos em que se insere a Cafeteria. Nesta figura, pode-se observar os mecanismos de governança que regem a interação da Pizza delivery com seus parceiros comerciais.

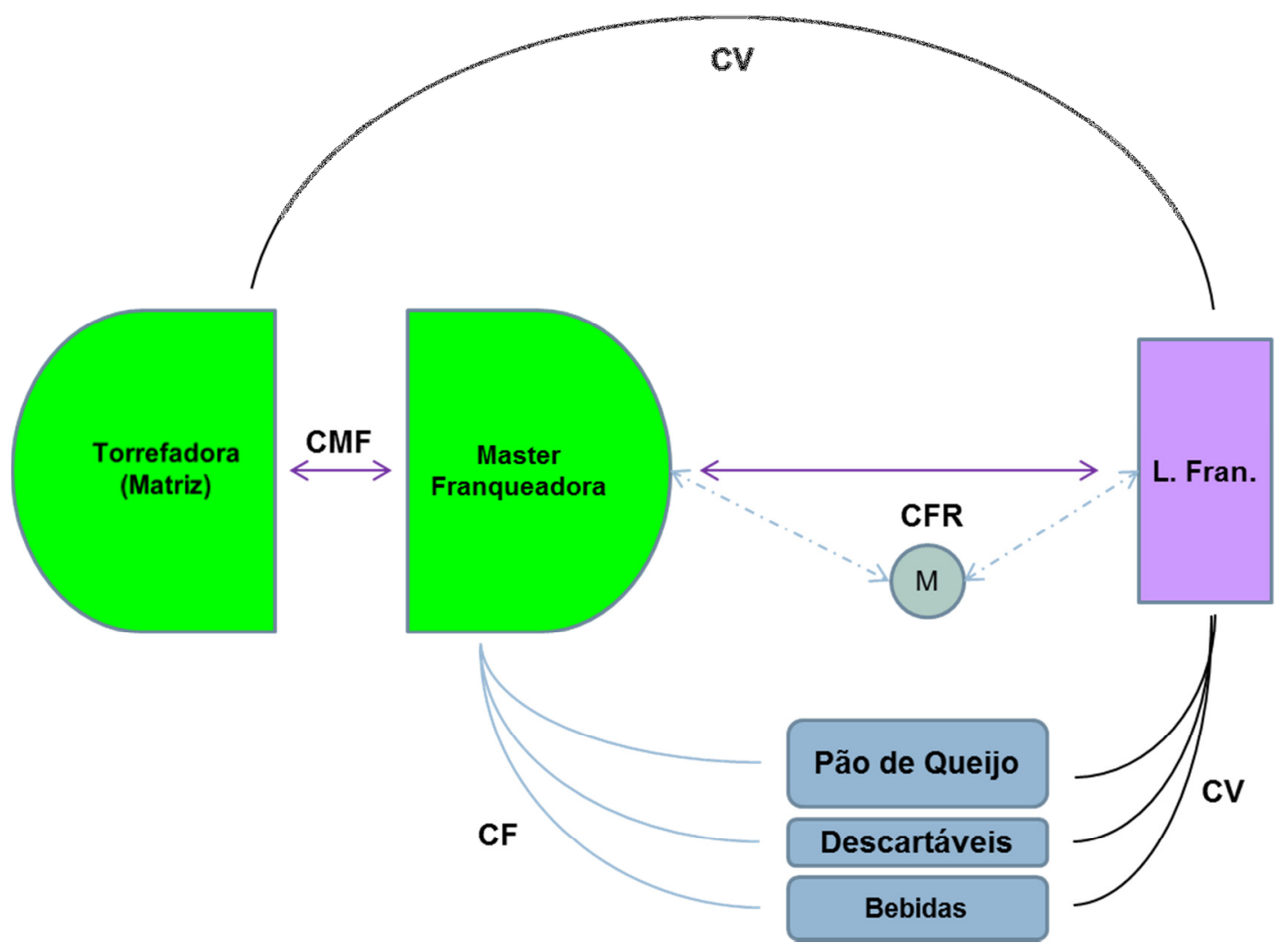

Figura 30 - Mecanismos de governança complementares associados à Cafeteria Fonte: elaborado pelo autor com base nas entrevistas

Sob a perspectiva da complementaridade contratual sugerida por Argyres e Liebeskind (1999), discutida na seção 7.3.2.3, vale destacar que nenhum mecanismo (complementar) de governança foi detectado influenciando diretamente a relação bilateral entre a máster franqueadora e suas lojas franqueadas. 


\subsection{Resumo do caso}

O Quadro 10, apresentado a seguir, oferece um resumo esquemático com as principais características observadas no Caso Cafeteria.

\begin{tabular}{|c|c|}
\hline & CAFETERIA \\
\hline Complexidade & $\begin{array}{l}\text { Baixa (indicada por uma pequena equipe total, de oito profissionais em dois } \\
\text { turnos, por loja). }\end{array}$ \\
\hline $\begin{array}{l}\text { Alocação de Direitos de } \\
\text { Propriedade na rede } \\
\text { (Tarefas Básicas) }\end{array}$ & $\begin{array}{c}\text { Sete tarefas são alocadas nas lojas (produção, gerenciamento da equipe, } \\
\text { marketing de vizinhança, gerenciamento financeiro, expansão da rede, } \\
\text { precificação e compras). }\end{array}$ \\
\hline $\begin{array}{l}\text { Mecanismos de } \\
\text { Governança Principais } \\
\text { (Ménard, 2010) }\end{array}$ & $\begin{array}{l}\text { Centro estratégico e contrato de franquia detalhado (baixo caráter } \\
\text { relacional). }\end{array}$ \\
\hline $\begin{array}{l}\text { Mecanismos de } \\
\text { Governança } \\
\text { Complementares }\end{array}$ & $\begin{array}{l}\text { Não foram observados mecanismos complementares dando suporte a } \\
\text { qualquer centralização de tarefas básicas no centro estratégico. }\end{array}$ \\
\hline $\begin{array}{l}\text { Controle Efetivo e } \\
\text { Monitoramento }\end{array}$ & $\begin{array}{l}\text { a) Acompanhamento de vendas via royalties. } \\
\text { b) Acompanhamento de compras via relatório de fornecedores. } \\
\text { c) Baixa intensidade de visitas formais. }\end{array}$ \\
\hline
\end{tabular}

Quadro 10 - Resumo esquemático do Caso Cafeteria

Fonte: elaborado pelo autor, com base nas entrevistas

Neste quadro, a Cafeteria foi retratada como uma cadeia de lojas em que a complexidade no ponto de venda é baixa (uma discussão mais completa sobre a classificação da cadeia em função de sua CPV, levando em consideração as outras variáveis do constructo além do tamanho da equipe, e uma comparação da complexidade entre as cadeias estudadas, será feita no Capítulo 11). 
A governança do arranjo híbrido é feita por meio de um contrato de franquia detalhado (com baixo caráter relacional) entre a máster franquia (centro estratégico) e as lojas franqueadas. Sete tarefas básicas estão alocadas na periferia da rede, sendo que não foram detectados mecanismos de governança complementares suportando a centralização de qualquer tarefa básica. O monitoramento é estabelecido de várias maneiras. Entre elas: o acompanhamento das vendas via royalties e taxa de franquia, o acompanhamento das compras via relatório de fornecedores e pela realização de vistas de inspeção (feitas em uma frequência baixa). 


\section{DISCUSSÃO DOS RESULTADOS}

Para iniciar a discussão dos resultados, será abordada em primeiro lugar a complexidade no ponto de venda, por esta ser a variável independente da hipótese do trabalho. Em seguida, serão vistos: a alocação de tarefas e os mecanismos de governança, tentando comparar analiticamente o que foi observado em cada caso estudado. Após comparar os casos, será discutida a adequação da hipótese proposta, culminando com a sugestão de um modelo que retrate o processo de descentralização em cadeias de food service franqueadas, em função da complexidade no ponto de venda.

\subsection{Complexidade no ponto de venda}

Conforme discutido nos Capítulos 8, 9 e 10, durante a condução dos casos, buscou-se atribuir a cada item do constructo um determinado peso à sua contribuição para o aumento da complexidade no ponto de venda. Vale relembrar, conforme discutido, que nas três entrevistas realizadas esse aspecto não foi conclusivo.

\begin{tabular}{|c|c|c|c|c|}
\hline & \multirow{2}{*}{ 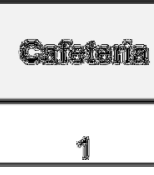 } & \multirow{2}{*}{ 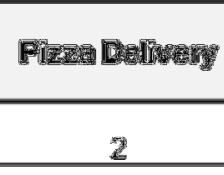 } & \multirow{2}{*}{$\frac{\text { Hewnhurgen }}{2}$} \\
\hline \multirow{6}{*}{ t } & Etapares & & & \\
\hline & Tec. finwerso & 2 & 2 & 1 \\
\hline & Rotinas (inwersof & 2 & 2 & $\mathbb{1}$ \\
\hline & Volume & 1 & 1 & 3 \\
\hline & Moluel Produto & 2 & 2 & it \\
\hline & Equipe & 1 & 2 & 3 \\
\hline \multirow{5}{*}{ 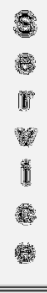 } & Extensete & 2 & 1 & 2 \\
\hline & Estrutuna & 2 & 2 & 3 \\
\hline & Volurne & 2 & $\mathbb{1}$ & 3 \\
\hline & 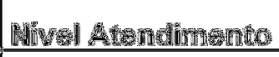 & 2 & 2 & 2 \\
\hline & Exquipe & 1 & 2 & 3 \\
\hline & Total & 날 & 19 & 24 \\
\hline
\end{tabular}

Quadro 11 - Comparação da CPV entre os casos

Fonte: elaborado pelo autor com base nas entrevistas 
O Quadro $11^{84}$, apresentado anteriormente, oferece uma visão de resultado supondo que todos os itens tenham a mesma influência (peso) na composição da complexidade no ponto de venda. Nesse quadro, a escala de classificação: baixa, média ou alta (usada durante a execução dos casos) foi substituída pela escala de valores: 1, 2 ou 3. De acordo com o referido quadro, a sequência crescente de complexidade no ponto de venda entre os casos estudados é:

\section{Cafeteria < Pizza Delivery < Hamburgeria (R1)}

O único resultado unânime obtido das entrevistas sobre a influência particular de cada um dos itens foi de que o 'tamanho total da equipe" seria o mais relevante como causa do aumento na complexidade dos pontos de venda. A escolha desta variável (tamanho da equipe) como melhor proxy para a complexidade no ponto de venda parece bastante alinhada à hipótese deste trabalho. Retomando a discussão teórica feita no Capítulo 7, Seção 7.2.2, assumiu-se que a complexidade no ponto de venda deveria ser vista como uma proxy para restaurantes que exigem alto investimento específico dos operadores. Como a gestão de equipe foi apontada nas entrevistas como a responsabilidade (atividade) que mais consome o tempo do franqueado, essa visão parece alinhada à hipótese do trabalho, à medida que quanto maior a equipe, mais tempo (e esforço) é exigido do franqueado para o seu gerenciamento.

O Quadro 12, apresentado a seguir, oferece uma comparação do tamanho das equipes médias, por loja, dos casos estudados.

\begin{tabular}{|r|c|c|c|}
\cline { 2 - 4 } & Cafeteria & Pizza Delivery & Hamburgeria \\
\cline { 2 - 4 } Total & 8 & 16 & 48 \\
\cline { 2 - 4 } Por Turno & 4 & 16 & 24 \\
\cline { 2 - 4 }
\end{tabular}

Quadro 12 - Comparação do tamanho das equipes entre os casos Fonte: elaborado pelo autor com base nas entrevistas

\footnotetext{
${ }^{84}$ Para facilitar uma apreciação da CPV resultante em cada caso, a classificação das variáveis 'tecnologia' e 'rotinas' neste quadro foi invertida, pois apenas estas duas variáveis têm correlação inversa sobre o aumento da complexidade no ponto de venda, como discutido na Seção 7.2.1.
} 
Fazendo uma comparação, a Cafeteria seria a operação mais simples, seguida pela Pizza Delivery e, por fim, a Hamburgeria seria a mais complexa, o que indica o mesmo resultado R1 apontado pela análise do Quadro 11.

Vale notar que, mesmo que o tamanho da equipe tenha um peso maior que os outros itens, e, seja esse peso qual for, o resultado sempre indicará a mesma sequência.

A seguir serão colocadas observações pontuais, focando cada variável em separado, que reforçam o resultado sugerido até agora:

- A diferença de volume de produto final entregue pela Hamburgeria e as outras duas cadeias é muito grande, o que reforça a ideia do desafio fabril da Hamburgeria ser significativamente maior do que das outras redes.

- A simplicidade processual da Cafeteria, tendo $90 \%$ do seu dia a dia voltado a esquentar pães de queijo e servir cafés, sugere um desafio bem mais simples que o da Pizza Delivery, e muitíssimo mais simples que o da Hamburgeria.

- As rotinas são adotadas para amenizar o desafio fabril. Nota-se que a Hamburgeria é a rede que adota uma proposta de maior aderência às rotinas. Porém, o estudo sugere que apesar de amenizar o desafio fabril, a aderência a rotinas não chega ao ponto de equalizar a complexidade quando são comparadas redes que operam volumes de produtos significativamente diferentes.

- Quanto às rotinas, o caso da Cafeteria deve ser visto com ressalvas, porque, apesar de a Cafeteria dar a devida importância às suas rotinas, este efeito acaba sendo pouco significativo, dada a sua simplicidade processual.

- No tocante ao nível do produto (perfil de sabor), o desafio maior parece estar ligado a manter um padrão de qualidade, do que trabalhar com um perfil de sabor mais elevado. Apesar de a Hamburgeria trabalhar com uma proposta mais simples, parece que tal fato não ameniza seu desafio, porque ela ainda tem que manter padrões rígidos de segurança alimentar para um volume grande de produção. O caso da Pizza Delivery segue o mesmo raciocínio. O estudo destes casos sugere que o perfil de 
sabor está mais ligado a uma opção de posicionamento (qualidade/preço) e utilização de matérias primas mais refinadas (caras e de melhor qualidade), do que com uma manipulação mais complexa. Talvez esta variável somente venha a ser significativa quando se analisam restaurantes de altíssimo padrão.

\subsubsection{Marketing de vizinhança e delivery}

Apesar de tudo que foi apresentado até este ponto indicar a mesma leitura quanto à complexidade no ponto de venda (Cafeteria < Pizza Delivery < Hamburgeria), chama a atenção que: a observação apenas do caráter de serviços e a observação do resultado geral do exercício sugerido no Quadro 11, apontam um resultado invertido (no caso do caráter de serviços, a CPV da Pizza Delivery, somatória: 8, é menor que a da Cafeteria, somatória: 9) ou muito próximo (no caso do resultado geral, os valores 18 e 19) entre a Cafeteria e a Pizza Delivery, levantando certa dúvida se a análise sugerida até agora seria mesmo a mais correta.

Esta questão foi discutida com o próprio sócio diretor da Pizza Delivery, que diz haver uma diferença básica entre um negócio dedicado ao delivery e praticamente todas as outras categorias de food service. Para o entrevistado, quando se trata de delivery, o desafio imposto a uma loja na operacionalização do marketing de vizinhança é significativamente maior.

O estudo de caso da Pizza Delivery realmente oferece indícios de que a visão recémapresentada seja realista. Diferente dos outros casos, o caso da Pizza Delivery apontou a gestão da equipe da loja e a operacionalização do marketing de vizinhança como sendo os dois maiores desafios dos franqueados da rede, sendo que o marketing de vizinhança consumiria cerca de $25 \%$ do tempo de dedicação do franqueado.

A importância do marketing de vizinhança também é reforçada pela expectativa muito mais demorada de ponto de equilíbrio da proposta da Pizza Delivery quando comparada a redes com atendimento de salão. Na proposta da Pizza Delivery, o ponto de equilíbrio ideal depende do esforço no marketing de vizinhança feito pelo franqueado e não apenas da marca e do fluxo de pessoas que circulam no entorno de uma loja (como num shopping). 
A expectativa geral de dedicação do franqueado também contribui para a visão de que a Pizza Delivery acabe sendo um desafio mais árduo que o da Cafeteria. Conforme foi observado na descrição dos casos, a Cafeteria espera uma dedicação máxima de seis horas de seus franqueados, enquanto a Pizza Delivery e a Hamburgeria esperam uma dedicação duas vezes maior.

Dentro desta visão, de que é necessário ajustar o constructo quanto ao marketing de vizinhança em casos especiais de lojas dedicadas exclusivamente ao delivery, a sequência crescente R1 de complexidade no ponto de venda proposta até agora: Cafeteria < Pizza Delivery $<$ Hamburgeria, volta a ser uma proposta consistente.

\subsection{Alocação de tarefas}

O Quadro 13, apresentado a seguir, retoma o que foi observado quanto à alocação de tarefas nos casos estudados.

\begin{tabular}{|l|c|c|c|}
\hline \multicolumn{1}{|c|}{ Tarefas } & Cafeteria & Pizza Delivery & Hamburgeria \\
\hline Desenvolvimento de Produtos & & & \\
\hline Des. de Promoções e Propaganda & & & \\
\hline Marketing Institucional & & & \\
\hline Mix de Produtos da Loja & & & \\
\hline Sistema (T.I.) de Gestão & & & \\
\hline Compras & $\mathbf{X}$ & & \\
\hline Precificação & $\mathbf{X}$ & $\mathbf{X}$ & $\mathbf{X}$ \\
\hline Expansão da Rede e Ponto Comercial & $\mathbf{X}$ & $\mathbf{X}$ & $\mathbf{X}$ \\
\hline Marketing de Vizinhança & $\mathbf{X}$ & $\mathbf{X}$ & $\mathbf{X}$ \\
\hline Gerenciamento Financeiro & $\mathbf{X}$ & $\mathbf{X}$ & $\mathbf{X}$ \\
\hline Gerenciamento da Equipe & $\mathbf{X}$ & $\mathbf{X}$ & \\
\hline Produção & $\mathbf{X}$ & & \\
\hline
\end{tabular}


A Cafeteria aloca sete tarefas básicas às suas lojas: a produção, a gestão da equipe, o gerenciamento financeiro, o marketing de vizinhança, a expansão da rede, a precificação e as compras. A Pizza Delivery aloca apenas cinco tarefas básicas, centralizando as compras e a precificação. Já a Hamburgeria se apresenta mais centralizada ainda, deixando apenas quatro tarefas alocadas às suas lojas.

A observação do Quadro 13 sugere uma alocação decrescente de direitos de propriedade (centralização) ao comparar a periferia (lojas) das redes estudadas. Parece ser possível observar um 'esvaziamento' de direitos de propriedade das lojas, ou seja, uma migração de direitos das lojas para os centros estratégicos (centralização). Vale salientar que o termo 'esvaziamento' está sendo usado para indicar uma diminuição dos direitos de propriedade de uma loja típica e não da cadeia como um todo.

Adotando o termo esvaziamento para indicar a centralização resultante especificamente da alocação de tarefas básicas no centro estratégico, pode-se ordenar os casos estudados quanto ao esvaziamento da seguinte maneira:

\section{Cafeteria $<$ Pizza Delivery < Hamburgeria $($ R2)}

Outra forma de observar o esvaziamento pode ser acompanhando uma única cadeia ao longo do tempo, à medida que ela vai mudando sua estratégia organizacional.

Um exemplo interessante de esvaziamento captado no caso da Pizza Delivery foi a centralização do atendimento telefônico. Conforme descrito ao longo do caso, em um primeiro momento esta tarefa estava alocada na periferia da rede; em um segundo momento sua alocação passou para o centro estratégico.

Um segundo exemplo, também no caso da Pizza Delivery, foi o caso da reforma do ponto comercial. $\mathrm{O}$ entrevistado comentou que a rede inicialmente deixava a reforma do ponto comercial por conta do franqueado, mas acabou centralizando informalmente esta tarefa. Nesse caso, além de observar um esvaziamento de responsabilidade, percebe-se que o ajuste foi feito informalmente, pois o contrato de reforma do ponto junto à empreiteira ainda é assinado pelo franqueado. 


\subsubsection{Esvaziamento e mecanismos complementares}

A observação das cadeias de suprimento como um todo, com foco na complementariedade entre os agentes (complementariedade contratual, baseada em Argyres e Liebeskind (1999), discutida na Seção 7.3.2.3) mostrou-se uma fonte de informação rica para entender o processo de esvaziamento. Nota-se que vários acordos entre os agentes viabilizam a centralização de um conjunto de direitos de propriedade pelos centros estratégicos das cadeias.

Alguns exemplos ajudam a ilustrar esta observação:

- No caso da Hamburgeria, o centro estratégico da rede centralizou a tarefa de expansão e escolha de ponto comercial. Nesta perspectiva, o contrato de aluguel firmado entre a máster franquia e o dono do imóvel deve ser visto como um mecanismo (complementar) imprescindível para viabilizar esta tomada de posição.

- Ainda no caso da Hamburgeria, a tarefa de compras também foi centralizada. Para que essa centralização ocorresse com sucesso, foi necessário que a Máster Franquia desenvolvesse uma relação com um distribuidor logístico. Para dar suporte a este fim, contratos de fornecimento de longo prazo entre o centro estratégico e o distribuidor logístico foram firmados. Neste caso, o distribuidor logístico chega a se comprometer a produzir internamente (integração vertical) uma parcela dos produtos que deverão estar disponíveis à rede de lojas.

- A utilização de um distribuidor logístico e de contratos de fornecimento de longo prazo também faz com que as compras da Pizza Delivery sejam praticamente centralizadas.

\subsection{Os mecanismos de governança à luz do modelo de Ménard (2010)}

A classificação quanto à utilização dos mecanismos de governança apontados pelo modelo de Ménard (2010) foi igual para as três redes, como ilustra o Quadro 14, apresentado a seguir. 


\begin{tabular}{|c|}
\hline Contratos \\
Relacionais
\end{tabular}

Quadro 14 - Comparação da ocorrência dos mecanismos de governança do modelo de Ménard nos casos I Fonte: elaborado pelo autor com base nas entrevistas

Os três estudos de caso indicaram uma mesma estratégia quanto à escolha dos mecanismos de governança apontados por Ménard (2010) no que tange a relação entre os componentes do arranjo. Observando apenas por este ângulo, não se detecta qualquer diferença na centralização dos arranjos.

Vale comentar que, mesmo se a presença dos comitês tivesse sido considerada relevante, e o preenchimento do quadro tivesse sido na linha intermediária, como ilustra o Quadro 15, apresentado a seguir, o resultado final seria o mesmo, porque os três casos continuariam ocupando a mesma posição, sugerindo não haver diferença na centralização.

\begin{tabular}{|c|c|c|c|c|}
\hline $\begin{array}{l}\text { Contratos } \\
\text { Relacionais }\end{array}$ & $\Longrightarrow$ & $\begin{array}{c}\text { Information- } \\
\text { Based-Networks }\end{array}$ & Third Party & $\begin{array}{c}\text { Centro } \\
\text { Estratégico }\end{array}$ \\
\hline $\operatorname{xxx} x \operatorname{xxx}$ & & $\mathbf{x}$ & & \\
\hline $\operatorname{xxxxxx}$ & & $\mathbf{x}$ & $\mathbf{x}$ & \\
\hline $\operatorname{xxxxx}$ & & & $\mathbf{x}$ & \\
\hline $\operatorname{XXXX}$ & & $\mathbf{x}$ & & $\mathbf{x}$ \\
\hline $\mathbf{x x x}$ & $\sqrt{2}$ & $\mathbf{x}$ & $\mathbf{x}$ & $\mathbf{x}$ \\
\hline $\mathbf{X X}$ & & & $x$ & $\mathbf{x}$ \\
\hline $\mathbf{x}$ & & & & $\mathbf{x}$ \\
\hline
\end{tabular}

Quadro 15 - Comparação da ocorrência dos mecanismos de governança do modelo de Ménard nos casos II Fonte: elaborado pelo autor com base nas entrevistas 
Nesta perspectiva, a centralização das cadeias estudadas pode ser representada pela sequência:

\section{Cafeteria $=$ Pizza Delivery $=$ Hamburgeria $(\mathbf{R 3})$}

\subsection{Controle efetivo e grau de adesão ao sistema}

Deve-se atentar ao fato de que algumas diferenças na relação entre centros estratégicos e lojas franqueadas acabam não sendo contempladas pela classificação feita em função do modelo de Ménard (2010). A classificação não conseguiu transmitir a informação de que existem níveis diferentes de adesão ao contrato de franquia sendo praticados nas redes de lojas estudadas.

Conforme visto no Capítulo 6, nesta ideia proposta inicialmente por Aghion e Tirole (1997) e aplicada ao franchising por Azevedo (2009): um mesmo modelo de contrato pode coordenar dois arranjos diferentes se a adesão efetiva ao contrato (maior controle efetivo) perpetuada pelas partes for diferente. Desta forma, sugere-se que a observação dos resultados sob a ótica de Ménard (2010) possa ser enriquecida observando também o grau de adesão ao sistema praticado em cada relação.

Alguns exemplos de conduta detectados nos estudos de caso sugerem diferentes graus de adesão ao sistema sendo praticados nas cadeias estudadas. Nas observações apresentadas a seguir, percebe-se que os centros estratégicos acabam por optar por diferentes níveis de controle efetivo sobre suas lojas franqueadas:

- A intensidade de visitas formais às lojas das três redes é muito diferente. Por este ângulo, espera-se mais controle efetivo sendo praticado pelos centros estratégicos que estão mais presentes no dia a dia de suas lojas. Entre os casos, as lojas mais visitadas (e monitoradas) são as da Hamburgeria, seguidas pelas lojas da Pizza Delivery e, por último, as lojas da Cafeteria.

- A Hamburgeria mostrou sua indisposição em aceitar uma baixa adesão ao seu sistema recomprando lojas que foram consideradas problemáticas (ou seja, lojas cujos franqueados mostraram-se avessos ao sistema). Deve-se lembrar sempre de que, 
diferente das outras redes, a Hamburgeria tem controle efetivo total sobre $70 \%$ de sua rede, visto que essas lojas são próprias.

- A existência de um sistema centralizado de captação de pedidos aumenta a possibilidade de monitoramento das lojas da Pizza Delivery pelo centro estratégico. Por outro lado, a postura de privilegiar sempre a orientação em vez de controle (captada na relação da Pizza Delivery com seus franqueados, descrita na Seção 9.5), permite ao centro estratégico exercitar um grau de tolerância considerável, sempre que quiser.

- A Cafeteria mostra sua alta tolerância à conduta de seus franqueados, aceitando um número significativo deles (60 a 70\%) dedicando-se apenas duas horas diárias às suas lojas.

- A Cafeteria aceita que algumas lojas incluam itens regionais no mix de produtos de certas lojas. Este tipo de postura também pode ser visto como uma forma encontrada pelo centro estratégico de oferecer alguma tolerância ao seu próprio sistema a algumas lojas, em casos especiais.

As observações sugerem que, apesar das três redes utilizarem os mesmos mecanismos de governança principais do modelo de Ménard (2010), elas adotam níveis de controle efetivo diferente, sugerindo a seguinte sequencia crescente de grau de adesão ao sistema (controle efetivo) sendo praticado entre os centros estratégico para com suas lojas:

\section{Cafeteria < Pizza Delivery < Hamburgeria (R4)}

\subsection{Proposta de modelo}

As quatro observações (R1, R2, R3 e R4) feitas a partir da comparação dos casos sugerem a seguinte relação entre complexidade no ponto de venda e o processo de centralização:

Quanto maior a complexidade no ponto de venda, maior será a centralização. 
De acordo com a análise e a comparação dos casos, um aumento da complexidade no ponto de venda (R1) deve levar a: a) uma manutenção dos mecanismos de governança principais (R3); b) um esvaziamento da alocação de direitos nas lojas (R2); e c) um aumento do controle efetivo dos centros estratégico sobre a rede (R4).

A seguir será apresentada uma proposta de modelo sobre a dinâmica da relação entre complexidade e centralização, baseada nas observações feitas a partir dos casos.

Suponha uma cadeia de food service em que o centro estratégico (franqueadora) e as lojas (franquias) competem por uma série de direitos de propriedade (A; B; C; D e E), de acordo com a proposta de Grossman, Hart e Moore, discutida no Capítulo 6.

Suponha, agora, que ocorra um aumento da complexidade nos pontos de venda (R1) desta rede. Hipoteticamente, poderia se pensar que a rede começou a: aumentar o tamanho de suas lojas, produzir um número maior de produtos nas lojas, atender um número maior de clientes, utilizar uma equipe maior, sofisticar seu atendimento etc. A Figura 31, apresentada a seguir, ilustra a situação em que uma franqueadora e suas lojas tomam conhecimento desta mudança, ou seja, do aumento de complexidade nos pontos de venda.

Franqueadora

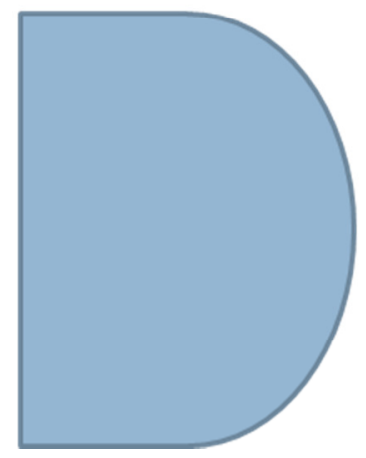

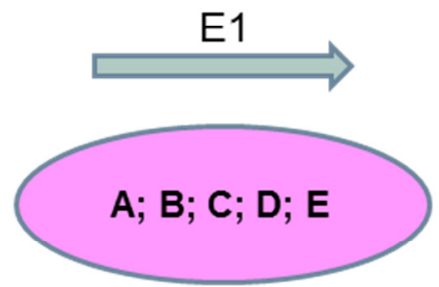

E2

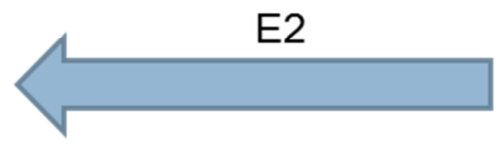

Franquia

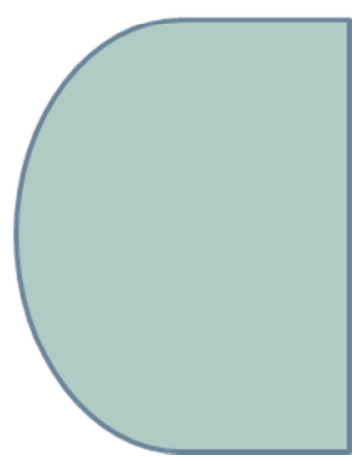

Figura 31 - Proposta de modelo para a relação entre CPV e centralização (parte 1) Fonte: elaborado pelo autor

Dois efeitos (E1 e E2) parecem ocorrer simultaneamente como resposta dos agentes (franquia e franqueadora, respectivamente) ao aumento da complexidade.

O franqueado se vê forçado a dedicar-se mais ao negócio, pois este passa a ser mais difícil de 
operar. Adicionalmente, é possível que ele deva aportar mais investimento (capital) na loja, para adequá-la ao novo perfil. Em ambos os casos, há um aumento do investimento específico por parte do franqueado, que, sob a perspectiva de GH\&M, aumenta a avidez deste agente pelos direitos de propriedade em jogo, pressionando a alocação destes direitos para periferia da rede (Efeito E1), numa franca tentativa de descentralização da cadeia.

O Efeito E1 é o efeito que se esperava quando a Hipótese deste trabalho foi lançada (Seção 7.2). Porém, não se observou descentralização alguma ocorrendo. Muito pelo contrário, o que se observou foi um processo de centralização.

Aparentemente, um segundo efeito, não antecipado na Hipótese deste trabalho, parece ocorrer também: o Efeito E2. Este efeito seria uma resposta do centro estratégico ao aumento da complexidade no ponto de venda, pressionando a alocação dos direitos de propriedade na direção contrária ao pretendido pelo franqueado, numa tentativa de promover a centralização.

Tudo indica que a pressão feita pelo centro estratégico seja muito maior que a pressão promovida pelo franqueado (E2 > E1), levando a uma resultante no sentido da centralização. A Figura 32, apresentada a seguir, ilustra o resultado dessa 'queda de braços'.
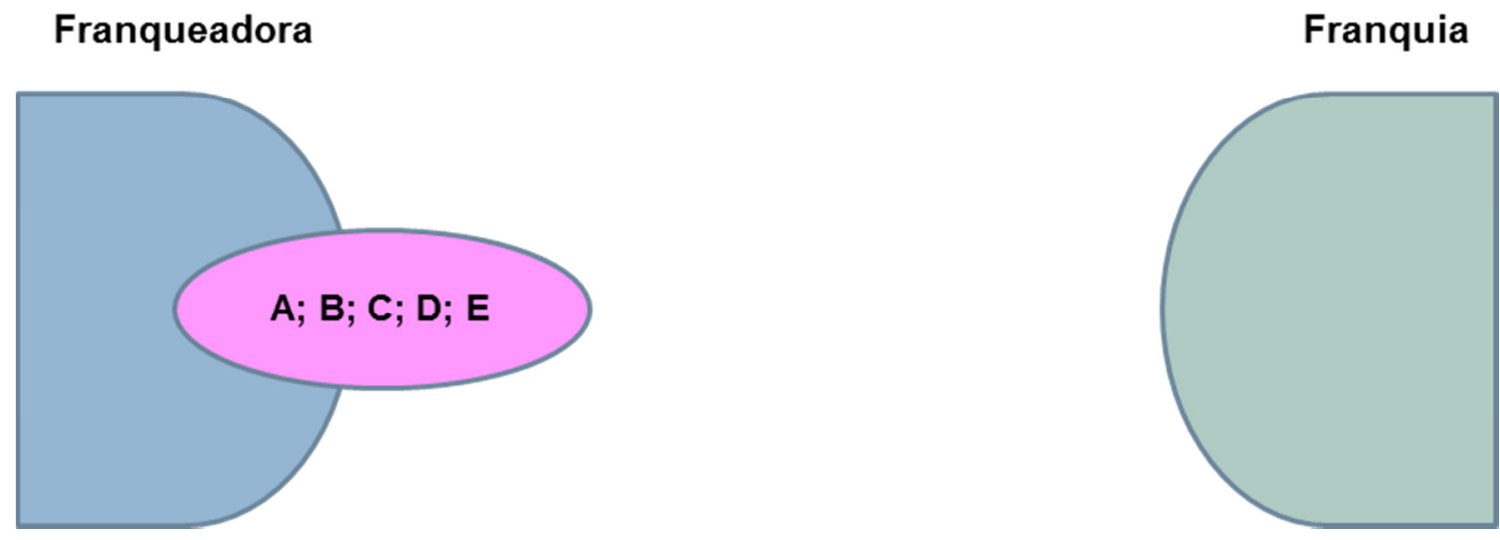

Figura 32 - Proposta de modelo para a relação entre CPV e centralização (parte 2) Fonte: elaborado pelo autor

Uma suposição plausível seja de que um aumento da complexidade no ponto de venda seja visto pela franqueadora como um aumento no risco de ter sua marca comprometida por alguma ação indevida de seus franqueados. A franqueadora percebe que haverá aumento na complexidade operacional das lojas (R1), o que pode gerar uma infinidade de problemas de 
performance, além de criar um ambiente mais propício a eventuais ações oportunistas por parte dos franqueados. Em resposta a essa ameaça, para proteger sua marca, a franqueadora busca ter mais controle sobre as decisões, tentando centralizar a alocação dos direitos de propriedade em jogo.

Porém, em vez de adotar a integração vertical como estratégia para centralização, a franqueadora opta por outro caminho: manter a estratégia organizacional baseada em franchising (R3), centralizar somente algumas tarefas básicas (R2) e aumentar seu controle efetivo sobre as tarefas restantes (R4).

A Figura 33, apresentada a seguir, ilustra a decisão estratégica final da franqueadora. Nesta figura, as tarefas A e B são alocadas no centro estratégico (R2) e as tarefas C, D e E continuam sendo compartilhadas com as lojas (R3). O alo (de cor azul) que passa a envolver as tarefas C, D e E simboliza o aumento de controle efetivo da franqueadora sobre as tarefas que não foram integradas (R4).
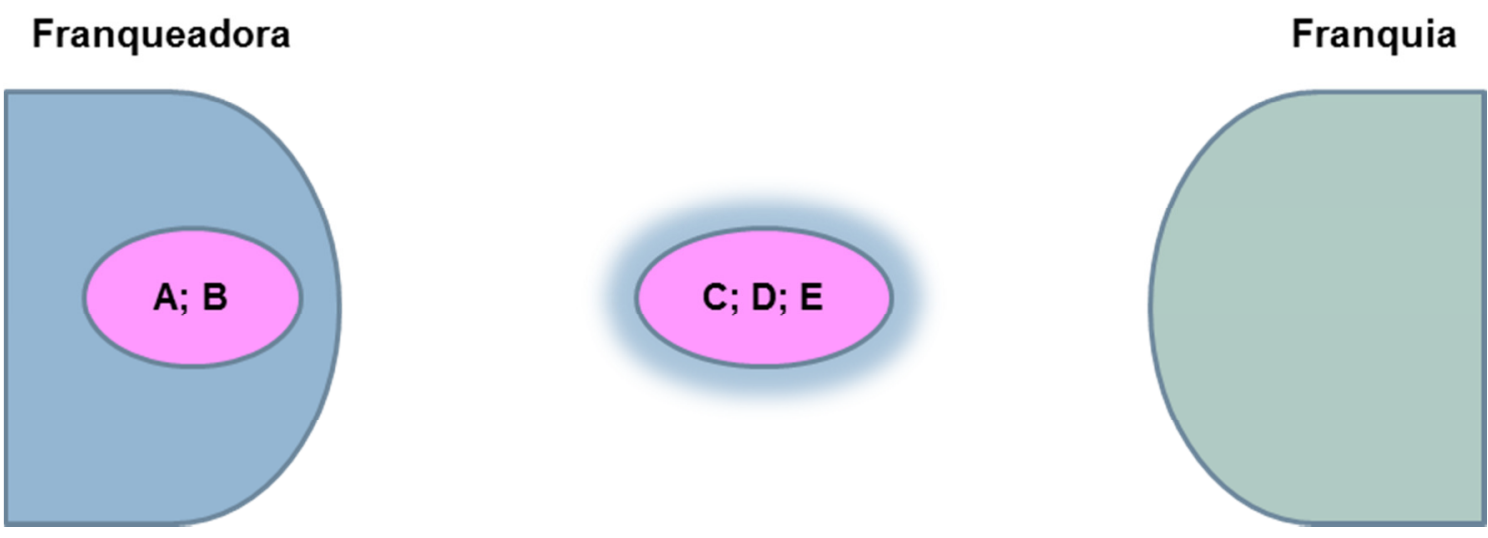

Figura 33 - Proposta de modelo para a relação entre CPV e centralização (parte 3) Fonte: elaborado pelo autor

De acordo com esta proposta, o esvaziamento (R2) funcionaria como uma ferramenta capaz de centralizar uma quantidade significativa de direitos de propriedade. Já o aumento no grau de adesão ao sistema (R4) funcionaria como uma ferramenta mais adequada para promover pequenos ajustes na capacidade de controle dos centros estratégicos.

De acordo com o insight de Coase (1937) sobre a busca da firma por uma estrutura de governança minimizadora de custos de transação (Seção 2.1), se o centro estratégico prefere 
manter a forma híbrida (R3) a verticalizar-se, deve-se entender que os custos de transação gerados pela estratégia franqueada ainda devem ser menores que os da opção verticalizada. Isto leva a crer que possa haver níveis de complexidade mais altos em que esta relação não seja mais positiva, e a integração vertical acabe sendo a opção ${ }^{85}$ mais eficiente.

\subsection{Aplicação gerencial}

A aplicação gerencial deste trabalho está ligada ao processo de escolha de uma estratégia organizacional por cadeias de food service.

O trabalho contribui com duas sugestões para o executivo que pretende utilizar a estutura de franquia como estratégia organizacional para uma cadeia de food service. A primeira delas é levar em conta a alocação de direitos de decisão (esvaziamento) na rede, e a segunda questão a ser observada é a intensidade da complexidade no ponto de venda.

Ao optar por um arranjo franqueado, o executivo responsável deve entender que esta decisão deve estar sempre alinhada a uma proposta de nível de centralização para a rede, pois o arranjo franqueado pode ter inúmeras variações dependendo de como as tarefas serão alocadas entre o centro estratégico (franqueadora) e suas lojas. A idéia central é que: de

${ }^{85} \mathrm{Um}$ exemplo que poderia ser discutido sob esta ótica é o da rede Outback. O Outback é uma cadeia de restaurantes americana que conta com 920 lojas espalhadas pelo mundo. No Brasil, a rede já instalou 64 lojas (OUTBACK, 2014). A culinária trabalhada na rede é sofisticada e seus restaurantes oferecem bastante comodidade aos seus clientes, atendendo em regime full service. Cada loja necessita de uma equipe bastante grande para ser operada e o processo de preparação dos pratos é bem mais artesanal que o de uma loja de fast food. Aparentemente, a complexidade no ponto de venda dessas lojas é muito grande e tudo indica que seja maior ainda do que a complexidade observada na Hamburgeria estudada neste trabalho. O Outback organiza sua rede da seguinte forma: assim que resolve abrir uma loja nova, a matriz seleciona um candidato a Proprietor para ser seu sócio neste empreendimento, assinando um contrato de sociedade com ele e dando origem a uma nova empresa. Nessa sociedade, o Proprietor é sempre um sócio minoritário, que detém algo em torno de 10 a $20 \%$ das cotas da empresa. Esta nova empresa deverá assinar um contrato de franquia com a própria Matriz, o Outback. De acordo com o modelo sugerido neste trabalho, o Outback deve ser visto como uma rede cuja complexidade no ponto de venda é muito alta e que precisa de uma estratégia que possa resistir a isso. Assim, para fazer frente ao desafio de manter uma rede de lojas tão difíceis de operar, o Outback lança mão de um mecanismo complementar para esvaziar quase que totalmente as responsabilidades de seus Proprietors: um contrato de sociedade. Acoplando este contrato ao contrato de franquia, assim como a Hamburgeria faz ao acoplar um contrato de locação de imóvel em seu arranjo, o Outback consegue ter todo controle que necessita para influenciar e monitorar o andamento de suas lojas eficientemente. 
acordo com as características intrínsecas de sua rede, haverá um nível ótimo de centralização (esvaziamento) a ser adotado. Este nível ótimo é aquele que trará o melhor retorno à empresa, aumentando sua competitividade. Optar pelo uso do arranjo franqueado é apenas parte da decisão, é necessário que seja definido também o design desse arranjo, ou seja, como será a alocação das tarefas na rede. Um exemplo neste sentido foi o processo de centralização tardia da tarefa de captação de pedidos no caso da Pizza Delivery. Uma análise apurada das características intrínsecas da rede teria evitado a necessidade de fazer esse ajuste ao longo do processo de expansão.

Este trabalho sugere que uma das características intrínsecas de cadeias de food service que deve ser considerada no momento de definição do nível de centralização de um arranjo franqueado é a complexidade no ponto de venda, pois, como sugerem os resultados recémdiscutidos, quanto mais complexos forem os restaurantes de uma cadeia, menos tarefas devem ser gerenciadas por estes restaurantes, para que o valor gerado pela rede seja maximizado, como foi observado no caso da Hamburgueria estudada.

\subsection{Próximos passos}

Entre os desdobramentos possíveis deste trabalho, vale ressaltar que:

- Uma possibilidade interessante seria testar quantitativamente a hipótese de que a centralização de redes franqueadas deva ser maior quando as lojas destas redes são mais complexas. No caso, este caminho seria uma continuação da visão da complexidade no ponto de venda como variável explicativa do processo de descentralização. Uma primeira possibilidade seria utilizar o tamanho da equipe das lojas como proxy da complexidade no ponto de venda.

- Além de testar o impacto da variável tamanho da equipe como proxy da complexidade no ponto de venda, seria interessante encontrar mais uma ou no máximo duas variáveis para efetivamente compor esse tipo de efeito, pois lidar com 11 possibilidades, como foi feito neste trabalho, mostrou-se uma opção difícil de lidar estatisticamente. 
- Uma questão sugerida neste trabalho que vale ser mais estudada é a do efeito individual da complexidade (Efeitos E1 e E2 - Figura 31) no ponto de venda sobre o franqueado e sobre o franqueador. Seria interessante confirmar se existe realmente um efeito sobre o franqueado oposto ao efeito no franqueador, como foi apresentado neste trabalho.

- Outro aspecto apontado pelo trabalho que merece ser investigado mais a fundo é o fenômeno de esvaziamento. O resultado deste trabalho sugere que pesquisas quantitativas que puderem incorporar esta ideia serão mais realistas. Uma sugestão prática neste sentido seria realizar o ajuste dos índices de delegação que utilizam a estrutura final de governança da cadeia em sua formação, como é o caso do Índice de Delegação proposto por Azevedo (2009).

Conforme abordado no Capítulo 3, Seção 3.4, Azevedo (2009) utiliza três componentes em seu índice. Um deles é o mix contratual, ou seja, a proporção de lojas próprias, que reflete a governança da cadeia. Essa governança poderia ser vista de maneira mais detalhada, aceitando mais classificações do que simplesmente loja própria (mais centralizada) e loja franqueada (menos centralizada). Poderia ser construído um leque maior de opções baseado no nível de esvaziamento de cada rede.

Tomando a classificação inicial proposta por Silva e Azevedo (2007) como ponto de partida, uma possibilidade mais completa seria:

○ Loja própria;

- Franquia quase-integrada (com contrato de sociedade acoplado);

- Franquia com locação de gerência (com contrato de operação de varejo acoplado);

- Franquia parcial sem ponto, sem compras e sem preço (com contrato de locação acoplado; imposição de compras centralizadas; preço final fixo);

- Franquia parcial sem compras e sem preço (imposição de compras centralizadas; preço final fixo);

- Franquia parcial sem compras (imposição de compras centralizadas);

- Franquia tradicional. 
- Outra possibilidade interessante, também alinhada ao item anterior, seria utilizar o nível de esvaziamento como controle em trabalhos quantitativos, como o de Azevedo (2009), que incorporam o número total de tarefas (tamanho do manual) como parte de seu índice de delegação.

Exemplo: Se a única diferença entre duas redes é que a Rede A opera com preço final fixo e a Rede B opera com preço final livre, o manual de ambas será igual, mas a centralização, não. Nesse tipo de situação, o número de tarefas final não reflete uma possível centralização. Se o esvaziamento da tarefa de precificação for controlado, a avaliação final será mais realista.

- Uma contribuição mais geral é a reafirmação da proposta de Ménard sobre a importância de se analisar as formas híbridas como um conjunto de famílias de arranjos. Somente devido a esta visão é possível visualizar algo como o fenômeno de esvaziamento, reforçando a ideia de que a análise de segmentos específicos, como este feito sobre o segmento de food service, seja um caminho enriquecedor. 


\section{REFERÊNCIAS}

AGHION, P.; TIROLE, J. Formal and Real Authority in Organizations. Journal of Political Economy, 105 (1): 1-29, 1997.

ALCHIAN, A. A. Property Rights. in: J. Eatwell, M. Milgate, and P. Newman (eds.), The New Palgrave, Vol. 3, MacMillan: London, p. 1031-1034, 1987.

ALCHIAN, A. A.; DEMSETZ, H. Production, information costs and economic organization. American Economic Review, Princeton, v. 62, p. 777 - 795, 1972.

ARGYRES, N.; LIEBESKIND, J. P. Contractual commitments, bargaining power, and governance inseparability: introducing history into Transaction Cost Theory. Academy of Management Review, v.24, p.49-63. 1999.

AZEVEDO, P. F. Allocation of Authority in Franchise Chains. International Studies of Management \& Organization, v. 39, p. 31-42, 2009.

AZEVEDO, P. F.; SILVA, A. G.; SILVA, V. L. S. Contractual Mix in Food Franchising. 6th Conference of the International Society for New Institutional Economics, MITCambridge-MA, 2002. (www.isnie.org).

BAKER, G. P.; GIL, R. Clinical papers in Organizational economics. In The Handbook of Organizational Economics. Gibbons Robert e John Roberts (editors). Princeton University Press, p. 1368, 2012.

BARNARD, C. The Functions of the Executive. Harvard University Press, Cambridge, MA, 1932.

BAUMOL, W. Welfare Economics and the Theory of the State. Cambridge, MA: Harvard University Press, 1952.

BLAIR, D. B.; LAFONTAINE, F. The Economics of Franchising. New York: Cambridge University Press, 2005.

BROUSSEAU, E.; RAYNAUD, E. The Economics of Private Institutions: An Introduction to the Dynamics of Institutional Frameworks and to the Analysis of Multilevel Multi-Type Governance (July 18, 2006). Disponível em: <<http://ssrn.com/abstract=920225>> ou em <<http://dx.doi.org/10.2139/ssrn.920225>>. Acesso em 12 jan.2014. 
CHD EXPERT, Segments Definition. 2014. Disponível em: <<http://www.chdexpert.com/data-management/segment-definition>> Acesso em 10 dez.2014.

COASE, R. H. The institutional structure of production. The American Economic Review, vol. 82, no 4, setembro, 1992.

COASE, R. H. The nature of the firm. Economica, v. 4, p. 386-405, 1937.

COLLIS, J.; HUSSEY, R. Pesquisa em Administração, Porto Alegre: Bookman, 2005.

COMMONS, J. R. The problem of correlating law, economics, and ethics. Wisconsin Law Review 8: 3-26, 1932

COOTER, R.; ULEN, T. Law and Economics. Glenview, Sott, Foresman and Company, 1988.

DEMSETZ, H. Toward a theory of property rights. The American Economic Review, Princeton, v. 57, n. 2, p. 347 - 359, 1967.

EGGERTSSON, T. Economic behavior and institutions. Cambridge: Cambridge University Press, 1990.

EUROMONITOR, Consumer Foodservice Global Overview: Finding Growth in a Fragmenting World, July, 2011.

EUROMONITOR, Consumer Foodservice in Brazil, October 2012.

FARIA, A. C. Anuário Brasileiro da Alimentação fora do Lar, 2013. Disponível em: $<<$ https://mega.co.nz/\#!a0RBXDCR!AHbCj1PL39IR3pzxLSPJ02-WafxGWqZ9V4P-

RQ5rwdY>>. Acesso em: 01 fev.2014

FARINA, E. M. M. Q.; AZEVEDO, P. S.; SAES, M. S. M. Competitividade: Mercado, Estado e Organizações. São Paulo: Editora Singular, 1997.

FOSS, K; FOSS, N. J. Resources and transaction costs: how propriety rights economics furthers the resource-based view. Strategic Management Journal, 26: 541-553, 2005. 
FRANCAP. A Empresa. Disponível em: <<http://www.francap.com.br/a-empresa >>. Acesso em: 01 fev.2014.

GIBBONS, R. Incentives between Firms (and within). Management Science, 51(1), 2-17, 2005.

GIBBONS, R. Incentives in Organizations. Journal of Economic Perspective, 12(4), 115$132,1998$.

GIRAFFAS. Sobre o Giraffas. 2014. Disponível em <<http://www.giraffas.com.br/sobre-ogiraffas/nossa-historia/>> Acesso em 01 fev.2014.

GROSSMAN, S. J.; HART, O. D. The Costs and Benefits of Ownership: A Theory of Vertical and Lateral Integration. J.P.E. 94 (August 1986): 691-719.

GROVE, S. J.; FISK, R. P. The Impact of Other Customers on Service Experiences: a Critical Incident Examination of Getting Along. Journal of Retailing 73, nº 10, p. 301-304, 1997.

GUERRA, A. F. Conduta competitiva das firmas no segmento de fast-food. 2010.64 f. Dissertação (Mestrado em Administração de Empresas) - Insper Instituto de Ensino e Pesquisa, São Paulo, 2010.

HART, O. D.; MOORE, J. Property Rights and the Nature of the Firm. J.P.E. 98 (December 1990): 1119-58.

HAYECK, F. A. The use of knowledge in society. The American Economic Review, v. 35, n. 4, p. $519-530$, Sep. 1945.

HOFFMAN, K. D. et al. Princípios de Marketing de Serviços: Conceitos, Estratégias e Casos. Tradução da $3^{\mathrm{a}}$ ed. Norte-Americana. São Paulo: Cenage Learning, 2009.

KLEIN, B.; CRAWFORD, R. G.; ALCHIAN, A. A. Vertical integration, appropriable rents, and the competitive contractive process. The Journal of Law and Economics, Chicago Press, v. 21, 1978.

KNIGHT, F. H. Risco, incerteza e lucro. Rio de Janeiro: Expressão e Cultura, 1972. 
KOTLER, P.; KELLER, K. L. Administração de marketing. 12.ed. São Paulo: Prentice Hall, 2006.

LACHINI, A. Alsea abrirá 30 restaurantes de comida chinesa no Brasil. Exame.com, 14 jan.2013. Disponível em: <<http://exame.abril.com.br/negocios/noticias/alsea-abrira-30restaurantes-de-comida-chinesa-no-brasil-2>>. Acesso em: 01 fev.2014

LAFONTAINE, F. Agency Theory and Franchising: Some Empirical Results. The RAND Journal of Economics, Vol. 23, No. 2, 1992.

LAFONTAINE, F.; SHAW, K. L. The Dynamics of Franchise Contracting: Evidence from Panel Data. Journal of Political Economy, V. 107, No. 5, 1999.

LAFONTAINE, F.; SLADE, M. E. Retail contracting: Theory and practice. Journal of Industrial Economics, Vol.45, No.1, 1997.

LANGEARD, E.; et al. Marketing of services: New Insights from Consumer and Managers. Relatório nº 81-104, Cambridge, Mass: Marketing Sciences Institute, 1981.

LLEWELLYN, K. N. What price contract? An essay in perspective. Yale Law Journal 40: 704-51, 1931.

LOVE. J. F. A verdadeira história do sucesso mcdonald's. $3^{\text {a }}$ edição - Editora Bertrand Brasil, 544pgs. 1988

MACNEIL, I. R. Contracts: adjustment of long-term economic relations under classical, neoclassical, and relational contract law. Northwestern University Law Review, 76(6), p. 854- 905, 1978.

MACNEIL, I. R. The Many Futures of Contracts. Southern California Law Review. 47 (May): 691-816, 1974

MAHONEY, J. T. Economic Foundations of Strategy. Thousand Oaks, California (USA): Sage Publications, 272 pages, 2005.

MARCONI, M. A.; LAKATOS, E. M. Metodologia científica: ciência e conhecimento científico; métodos científicos; teoria, hipóteses e variáveis; metodologia jurídica. 3 ed. rev. ampl. São Paulo: Atlas, 2000. 
MAXIMIANO, A. C. A. Teoria geral da administração: da revolução urbana à revolução digital. $7^{\text {a }}$ Ed. São Paulo: Editora Atlas, 504 p.., 2012.

MCDONALD'S. McDonald's History. Disponível em: <<http://www.aboutmcdonalds.com/mcd/our_company/mcdonalds_history_timeline.html >> Acesso em: 01 fev.2014.

MCELHERAN, K. Delegation in Multi-Establishment Firms: Evidence from I.T. Purchasing. Harvard Business School, Working Paper, 1-51, 2013.

MÉNARD, C. Hybrid Modes of Organization. Alliances, Joint Ventures, Networks, and Other 'Strange' Animals. In R. Gibbons and J. Roberts, The Handbook of Organizational Economics, Princeton: Princeton University Press, Chapter 26: 1066-1108, 2010.

MÉNARD, C. The Economics of Hybrid Organizations. Journal of Institutional and Theoretical Economics, Mohr Siebeck, v. 160, n. 3, p. 345 - 376, 2004.

Ménard, C.; Reynaud, E. Ulysses and the Sirens: Hands-Tying Governance in Hybrid Organizations. Preliminary draft, This version: September 2010.

MINISTÉRIO DO DESENVOLVIMENTO, DA INDÚSTRIA E DO COMÉRCIO EXTERIOR. Cartilha - $\mathbf{O}$ que é franquia? 2006. Disponível em: $<<$ http://www.sebrae.com.br/uf/amapa/abra-seu-negocio/como-abrir-umafranquia/cartilha_o_que_e_franquia_-_mdic.pdf.>> Acesso em: 08 set.2013.

NORTH, D. C. Custos de Transação, Instituições e Desempenho Econômico. Rio de Janeiro: Instituto Liberal, 1994.

NORTH, D. C. Institutions, Institutional Change and Economic Performance. New York: Cambridge University Press, 1990.

OUTBACK. Sobre o Outback. $<<$ https://www.outback.com.br/institucional/>>. Acesso em: 01 fev.2014.

POPPO, L.; ZENGER, T. Do Formal Contracts and Relational Governance Function as Substitutes or Complements? Strategic Management Journal, 23: 707-725, 2002.

RUBIN, P. H. The theory of the firm and the structure of the franchise contract. Journal of Law and Economics, v. 21, 1978. 
SHOSTACK, G. L. Breaking Free from Product Marketing. The Journal of Marketing 41 (April, 1977) p. 73-80

SILVA, V. L. S.; AZEVEDO, P. F. Contratos interfirmas em diferentes ambientes institucionais: o caso McDonald's França versus Brasil. R. Adm., São Paulo, v.41, n.4, p.381393, out./nov./dez. 2006.

SILVA, V. L. S.; AZEVEDO, P. F. Formas Plurais no Franchising de Alimentos: Evidências de Estudos de Caso na França e no Brasil. RAC, 1a. Edição Especial 2007: 129-152.

SIMON, H. A. Administrative Behavior. New York: Macmillan, 1947.

SIMON, H. A. Models of Man, New York: John Wiley e Sons, 1957.

SUBWAY. Histórico. 2014. Disponível em: <<http://www.subway.com.br/historico >>. Acesso em: 01 fev.2014.

TEECE, D. J.; PISANO G.; SHUEN A. Dynamic Capabilities and Strategic Management. Strategic Management Journal, Vol. 18, No. 7. (Aug., 1997), p. 509-533.

THOMPSON, J. D. Organization and Output Transactions. American Journal of Sociology 68,1967 , p. $309-324$

UNITED STATES DEPARTMENT OF AGRICULTURE, ECONOMIC RESEARCH SERVICE (USDA-ERS), Sales of meals and snacks away from home by type of outlet (Table 15), Last Updated 01/12/2014. 2014a. Diponível em: <<http://www.ers.usda.gov/dataproducts/food-expenditures.aspx $>>$. Acesso em: $10 \mathrm{dez} .2014$

UNITED STATES DEPARTMENT OF AGRICULTURE, ECONOMIC RESEARCH SERVICE (USDA-ERS), Methodology for the Quarterly Food-Away-from-Home Prices Data. Technical Bulletin Number 1938, May 2014. 2014b. Disponível em: <<http://www.ers.usda.gov/media/1435449/tb-1938.pdf>>. Acesso em: 10 dez.2014

VANCE, P. S. Determinantes e dinâmica do uso de formas plurais em redes de franquias. 2010. 295 f. Tese (Doutorado em Administração de Empresas) Faculdade de Economia, Administração e Contailidade , Universidade de São Paulo, 2010..

WILLIAMSON, O. E. Comparative economic organization: the analysis of discrete structural alternatives. Administrative Science Quarterly, n. 36, p. 269-296, June, 1991. 
WILLIAMSON, O. E. Hierarchies and Markets. International Encyclopedia of the Social \& Behavioral Sciences, p. 6690-6693, 2001.

WILLIAMSON, O. E. Markets and Hierarchies. Analysis and Antitrust Implications, New York et al.: Free Press, 1975.

WILliAMSON, O. E. The Economic Institutions of Capitalism: Firms, Markets, Relational Contracting. New York: The Free Press, 1985.

WILLIAMSON, O. E. The mechanisms of governance. New York: Oxford University Press, 1996.

YIN, R. K. Case Study Research: Design and Methods. SAGE Publications, Newbury Park, Edição Cultural, 1989.

ZOTT, C.; AMIT, R.; MASSA, L. The Business Model: Theoretical Roots, Recent Developments, and Future Research. IESE Business School - University of Navarra, Working Paper WP-862, Rev. September 2010. 


\section{ANEXO I}

Formato Contratual Empregado conforme Mercado de Atuação das Redes investigadas na Análise Comparada do Franchising Brasileiro e Francês

\begin{tabular}{|c|c|c|c|c|c|}
\hline \multirow[b]{2}{*}{ Redes / mercado de atuação } & \multirow[b]{2}{*}{ Segmento } & \multicolumn{4}{|c|}{ Formato Contratual } \\
\hline & & $\begin{array}{c}\text { Franquia } \\
\text { Convencional }\end{array}$ & $\begin{array}{c}\text { Franquia } \\
\text { Parcial }\end{array}$ & $\begin{array}{l}\text { Locação de } \\
\text { Gerência }\end{array}$ & $\begin{array}{l}\text { Hierarquia } \\
\text { (loja } \\
\text { própria) }\end{array}$ \\
\hline $\begin{array}{r}\text { Segafredo Zanetti } \\
\qquad \begin{array}{r}\text { mercados-alvo } \\
\text { outros países }\end{array}\end{array}$ & & • & $\begin{array}{l}\mathrm{NE} \\
\mathrm{NE}\end{array}$ & $\dot{\mathrm{NE}}$ & $\cdot$ \\
\hline Fran's Café $\quad$ Brasil & cafeterias & $\bullet$ & NE & NE & $\cdot$ \\
\hline Café do Ponto & & - & $\mathrm{NE}$ & NE & $\cdot$ \\
\hline Café Pelé $\quad$ Brasil & & • & NE & NE & $\cdot$ \\
\hline Casa do Pão de Queijo $\quad$ Brasil & & $\bullet$ & NE & NE & $\bullet$ \\
\hline $\begin{array}{r}\text { Dunkin'Donuts } \\
\qquad \text { padrão mundial } \\
\text { Brasil }\end{array}$ & doces \& & $\begin{array}{c}\text { NE } \\
\bullet\end{array}$ & $\dot{\mathrm{NE}}$ & $\dot{\mathrm{NE}}$ & • \\
\hline The Nutty Bavarian $\quad$ Brasil & chocolates & $\cdot$ & NE & $\mathrm{NE}$ & $\cdot$ \\
\hline Amor aos Pedaços Brasil & & • & NE & NE & - \\
\hline Jeff de Bruges $\quad$ padrão mundial & & $\bullet$ & $\mathrm{NE}$ & $\mathrm{NE}$ & $\cdot$ \\
\hline $\begin{array}{l}\text { Quick } \\
\text { mercados-alvo }(F r, B e, L u) \\
\text { outros países }\end{array}$ & & $\begin{array}{c}\mathrm{NE} \\
\bullet\end{array}$ & $\stackrel{\bullet}{\mathrm{NE}}$ & $\stackrel{\bullet}{\mathrm{NE}}$ & $\cdot$ \\
\hline $\begin{array}{r}\text { McDonald's padrão mundial } \\
\text { Brasil } \\
\end{array}$ & fast food & $\begin{array}{l}\mathrm{NE} \\
\mathrm{NE}\end{array}$ & $\dot{\bullet}$ & $\begin{array}{c}\cdot \\
\mathrm{NE} \\
\end{array}$ & $\dot{\bullet}$ \\
\hline $\begin{array}{r}\text { padrão mundial } \\
\text { Brasil } \\
\end{array}$ & Jasi jorat & $\begin{array}{c}\mathrm{NE} \\
\cdot\end{array}$ & $\dot{\mathrm{NE}}$ & $\dot{\mathrm{NE}}$ & $\dot{.}$ \\
\hline $\begin{array}{ll}\text { China in Box } & \text { Brasil }\end{array}$ & & $\cdot$ & NE & NE & $\cdot$ \\
\hline Vivenda do Camarão & & $\bullet$ & NE & $\mathrm{NE}$ & $\cdot$ \\
\hline $\begin{array}{ll}\text { Habib's } & \text { Brasil }\end{array}$ & & $\bullet$ & $\mathrm{NE}$ & $\mathrm{NE}$ & $\cdot$ \\
\hline $\begin{array}{l}\text { Grill Courtepaille } \\
\quad \text { padrão mundial }\end{array}$ & & $\cdot$ & NE & NE & - \\
\hline $\begin{array}{cc}\text { La Boucherie } & \begin{array}{c}\text { mercados-alvo } \\
\text { outros países }\end{array} \\
\end{array}$ & grelhados & $\dot{\bullet}$ & $\begin{array}{l}\mathrm{NE} \\
\mathrm{NE}\end{array}$ & $\dot{\mathrm{NE}}$ & $\dot{\bullet}$ \\
\hline Brasil & & $\bullet$ & $\mathrm{NE}$ & $\mathrm{NE}$ & $\cdot$ \\
\hline Kopenhagen & & - & NE & NE & - \\
\hline $\begin{array}{r}\text { Comtesse du Barry } \\
\text { mercados-alvo } \\
\text { outros países }\end{array}$ & $\begin{array}{l}\text { produtos } \\
\text { finos }\end{array}$ & $\dot{\bullet}$ & $\begin{array}{l}\mathrm{NE} \\
\mathrm{NE}\end{array}$ & $\dot{\mathrm{NE}}$ & $\dot{\bullet}$ \\
\hline
\end{tabular}

FONTE: Silva e Azevedo, 2007, p. 139 
ANEXO II

\section{ROTEIRO PARA ENTREVISTA}

\section{PARTE I - ESTRUTURA ORGANIZACIONAL}

\section{1) SOBRE A EQUIPE DE SUPERVISÃO DAS LOJAS:}

- Existe equipe de contato da Matriz (ou Máster Franquia) interagindo direto com os PDV?

- Essa equipe se reporta a quem?

- No caso de haver Máster Franquia, existem atividades em que há contato entre Matriz e PDV? Qual intensidade?

Significativa ( ) Média () Baixa ()

○ Quantas lojas (PDV) essa equipe atende?

- Quantos cargos diferentes formam essa equipe?

○ Qual o número total de profissionais nessa equipe?

○ Grau de instrução médio da equipe (supervisores)?

- Como essa equipe interage (hierarquicamente) com a loja própria? Com quem é o contato na loja? Quais atividades desempenham?

- Como essa equipe interage (hierarquicamente) com a loja franqueada? Qual a diferença comparando com a loja própria?

- A equipe de supervisão gasta mais horas/homem dando apoio às lojas próprias? Essa diferença é?

Significativa ( ) Média ( ) Baixa ( )

\section{2) SOBRE A EQUIPE “DEDICADA" NA M. FRANQUIA E NA MATRIZ:}

○ Principais atores (cargos) e responsabilidades

- Detalhar quais cargos são de supervisão, operacional e treinamento e quais são estratégicos (desenvolvimento de produtos, desenvolvimento de campanha publicitária, negociação com fornecedores)....para não confundir com a pergunta anterior! 
3) SOBRE A EQUIPE DA LOJA:

Q Quais os diferentes cargos?

○ Existe diferença de salário entre os cargos? Qual, aproximadamente?

○ Número médio de funcionários por loja?

○ Salário médio?

○ Jornada média semanal?

○ Grau de instrução média da Gerência?

- Grau de instrução média do atendente?

○ Qual a porcentagem de lojas que não têm gerentes? (Nem gerente, nem franqueado gerente)

○ Qual a porcentagem de lojas com Gerentes Profissionais?

○ Qual porcentagem com Sócio Operador Gerente?

○ Qual o turn-over médio dos funcionários?

\section{4) SOBRE O SÓCIO OPERADOR}

○ Qual o número médio de lojas que um franqueado tem?

○ Qual dedicação horas/dia solicitada no contrato ao Sócio-Operador?

○ Qual dedicação horas/dia real dos Sócios-Operadores?

- Como a franquia espera que essa dedicação se mantenha se o número de lojas por franqueado crescer? Isso faz diferença? Existe um ponto ótimo?

- É comum a participação de familiares ou pessoas de confiança na do sócio operador na gestão da loja?

Em que cargo?

Com que frequência?

Qual o parentesco mais comum?

- Na prática (na realidade), qual a composição média das atividades do sócio operador (percentualmente)?

- $\%$ do seu tempo dedicado a treinamento da equipe?

- \% do seu tempo monitorando a equipe?

- $\%$ do seu tempo interagindo com clientes?

- \% do tempo efetuando compras?

- $\%$ em manutenção da estrutura física da loja?

- $\%$ em pagamento de funcionários, contas a pagar?

- $\%$ operando caixa? 
- $\%$ envolvido em campanha de publicidade?

- $\%$ outros?

- Em termos contratuais, a resposta da pergunta anterior seria outra?

○ Qual o turn-over de sócio operador por loja? Ou, índice de recompra de lojas pela franquia? Ou, diferença de idade das lojas e da participação de seus franquiados?

○ Como (quem) se escolhe o franqueado?

- Existe preferência interna a franqueado da casa? Ou, a indicados (parentes) dos atuais franqueados?

- Entre Máster Franquia e Matriz, como se divide a autoridade sobre a decisão?

- A rede de franqueados interfere, opina, participa dessa decisão?

- Qual \% de franqueados DONOS dos pontos comerciais? Isso interfere no processo de captação de novos franqueados? Significativa ( ) Média () Baixa ()

- Quanto tempo demora o processo seletivo para um novo franqueado?

- Quais os critérios básicos dessa seleção?

\section{5) CONTROLE e MONITORAMENTO?}

- Qual o índice de vistorias da franquia sobre o franqueado? Número de visitas tipo inspeção por mês?

○ Há comprador oculto? O que você espera medir com isso? Se a loja dá nota? Também mede o nível do atendimento?

- Quais os outros mecanismos usados para monitorar a loja?

○ O monitoramento é mais focado na "lisura" do franqueado para com a Franquia, ou no nível de desempenho da operação (produto e serviço) oferecido ao cliente? Existem mecanismos para monitorar a dedicação do sócio operador?

- Você considera o monitoramento, comparando com outras redes, na prática: Significativo ( ) Médio ( ) Baixo ( )

○ O detalhamento do manual é completo? Dá margem a dúvidas?

- Você acredita que o manual é algo importante no dia-a-dia, ou a informação é transmitida de outra forma, como por exemplo, por treinamento? Se existe falta de uso prático do manual, você diria que isso é: 
Significativo ( ) Médio ( ) Baixo ( )

- O detalhamento do manual, comparado com outras redes:

Significativo ( ) Médio () Baixo ( )

○ Quais são as medidas punitivas de direito? Na prática, elas são usadas? Qual a intensidade desse uso?

Significativo ( ) Médio ( ) Baixo ( )

6) MIX CONTRATUAL (A REDE)

○ Número de Lojas Próprias?

○ Número de Lojas Franqueadas?

○ Número total de Franqueados?

○ Número de Lojas em média por franqueado?

- Idade média das lojas no Brasil?

○ Idade média dos contratos de franquia?

○ Existe política de sucessão?

○ Como se da o repasse?

\section{PARTE II - OPERAÇÕES EM ADMINISTRAÇÃO}

\section{A) MARKETING E VENDAS}

1) SOBRE O PDV

- Faturamento médio de uma loja?

○ Número médio de atendimentos por loja (semanal ou mensal)?

○ Ticket médio?

○ Composição média do atendimento: quais itens?

- TIPOS de LOJA: Existe diferença significativa no faturamento de:

- Loja externa com drive?

- Quantas há na rede?

- Loja externa de calçada (in store)?

- Quantas há na rede?

- Loja de Shopping com salão

- Box em shopping 
- Existe diferença significativa nos turnos (tempo por semana que fica operando) de:

- Loja externa com drive

- Loja externa de calçada (in store)

- Loja de Shopping

○ Número de itens no cardápio?

○ Como é a dispersão (concentração) das vendas em relação à linha de produtos?

\section{1) SOBRE O DESENVOLVIMENTO CONCEITUAL DO PRODUTO:}

○ Quem participa?

- Existe Comité de Franqueados atuando nessa atividade?

- Existe uma equipe na Matriz para certos produtos e outra na Máster Franquia?

O Os supervisores participam?

○ Qual a participação efetiva do franqueado nessa decisão?

Significativa ( ) Média () Baixa ()

○ O desenvolvimento de novos produtos (+lançamento) é algo importante na estratégia de marketing?

\section{2) SOBRE A PROMOÇÃO E PROPAGANDA LOCAL:}

○ Quais as principais ações de marketing local?

- Panfletagem?

- Ação conjunta com outro estabelecimento?

- Existe promoção individual?

- Campanhas promocionais em rede?

○ Quem cria as campanhas?

○ Quem toma a decisão para cada loja sobre qual ferramenta usar?

○ O franqueado tem autonomia para decidir? Significativa () Média () Baixa ()

- Existe um valor acertado previamente que o franqueado terá obrigação de investir, periodicamente?

- A Matriz tem que aprovar as ações de marketing local de cada unidade franqueada ou loja própria?

- Qual a participação efetiva do gerente de uma loja própria nesse processo?

○ Significativa ( ) Média () Baixa () 
3) SOBRE A PROMOÇÃO E PROPAGANDA COLETIVA:

- Quem participa? Existe Comité de Franqueados atuando nessa atividade?

- Entre Máster Franquia e Matriz, como se divide a autoridade sobre a decisão?

○ Qual a participação efetiva do franqueado nessa decisão?

○ Significativa () Média () Baixa ()

\section{4) SOBRE A EXPANSÃO:}

○ Que escolhe a localização do novo ponto?

○ Qual a participação efetiva do franqueado nessa decisão? Significativa () Média () Baixa ()

- Entre Máster Franquia e Matriz, como se divide a autoridade sobre a decisão?

- Há mais lojas franqueadas em locais idiossincráticos como o interior? Se existem, é significativo?

Significativo () Médio () Baixo ()

- Quem define o território de cada loja?

5) SOBRE A PRECIFICAÇÃO:

○ Quem define o preço final dos produtos no PDV?

○ O franqueado tem margem (intervalo) para escolher? Qual intervalo?

6) SOBRE A LINHA DE PRODUTOS COMERCIALIZADA NO PDV:

- Os PDV comercializam $100 \%$ da linha?

○ Quem decide o cardápio?

○ Qual a participação efetiva do franqueado nessa decisão?

Significativa () Média () Baixa ()

\section{B) PRODUÇÃO}

1) Sobre a atividade de compras?

- Há alguma central de compras?

- Há alguma operadora logística?

- Quem efetua as compras?

- Quem aprova os fornecedores? 
- Existem problemas de abastecimento a serem enfrentados (ex: sazonalidade e variação na qualidade do camarão, no caso da Vivenda).

- A Matriz tb é fornecedora da rede?

- A embalagem é uma parte importante do seu negócio (Ex: China in Box, McD`s), quem compra (desenvolve com fornecedor) essas embalagens?

- Quem negocia os contratos de fornecimento de longo prazo com fornecedores?

\section{2) SOBRE O DESENVOLVIMENTO TÉCNICO DE PRODUTOS:}

- Quem participa? Técnicos (engenheiros de alimentos) altamente qualificados estão envolvidos nesse processo? Onde eles trabalham, na Matriz ou na Máster Franquia?

\section{3) SOBRE O USO DE SISTEMAS DE GESTÃO (SOFTWARE) NA LOJA:}

- Quem escolhe o softwaresoftware? Existe comitê para inovação em T.I.?

○ Qual a participação efetiva do franqueado nessa decisão?

Significativa ( ) Média () Baixa ()

- O software permite monitoramento da operação da loja pela Matriz ou Máster Franquia?

\section{C) RECURSOS HUMANOS}

\section{1) Sobre a formação da equipe da loja:}

○ Quem contrata e demite?

○ Qual a participação efetiva do franqueado nessa decisão?

$$
\text { Significativa () Média () Baixa () }
$$

○ Quem aplica os treinamentos?

○ O franquiado participa diretamente (pessoalmente)?

○ Qual a porcentagem dos franqueados que faz isso?

$$
\text { Significativa () Média () Baixa () }
$$

- Qual o investimento (em horas) que a franquia PEDE (manual) pede que o franqueado faça em cada nova contratação e na manutenção da equipe?

- Qual o investimento (em horas) que a franquia ESPERA que o franqueado faça em cada nova contratação e na manutenção da equipe? 
○ Quem define o salário da equipe?

- As rotinas a serem ensinadas estão descritas no manual de franquia?

○ E a "forma" de remuneração (fixo, comissão, bônus por resultado, participação nos lucros)? Quem define?

\section{D) FINANÇAS}

O O PDV tem contador próprio?

○ Quem é responsável por efetuar as contas a pagar e a receber?

○ Qual diferença da loja própria e da franqueada?

\section{PARTE III - COMPLEXIDADE}

\section{A) PREPARO TÉCNICO $x$ PREPARO ARTESANAL (FOOD)}

○ Número médio de atendimentos por loja (semanal ou mensal)?

○ Composição média do atendimento: quais ítens

- Qual o número de insumos totais comprados?

- Qual a porcentagem comprada diretamente pelo PDV e a partir de centrais de compra?

○ Quantos insumos, em média, compõem um atendimento?

- Qual o número de itens "ïn natura" (fresco ou refrigerado, tipo FLVs, com prazo de validade máximo de 1 mês) usados? Quais são esses itens? Seu uso é intenso?

Significativo ( ) Médio ( ) Baixo ( )

○ Qual o número de itens "semi-industrializados" (congelado ou forneado, com prazo de validade maior que 1 mês) usados? Quais são esses itens? Seu uso é intenso?

Significativo ( ) Médio ( ) Baixo ( )

- Qual a intensidade de uso de equipamentos industriais?

Significativa () Média () Baixa ()

○ Qual a porcentagem de funcionários na cozinha, frente ao total da loja?

- Qual a porcentagem de funcionários na cozinha, frente ao número de funcionários que atendem os clientes?

- Existem cargos diversos dentro da equipe da cozinha? 
- Qual diferença (número de horas) entre o treinamento do operador de cozinha e das outras atividades da loja?

○ Qual o tempo médio de preparo de um pedido, após ser coletado?

○ Qual o espaço, em metros quadrados, médio da cozinha? Em relação ao tamanho da loja?

○ Existe desperdício no preparo?

Significativo ( ) Médio ( ) Baixo ( )

- Você considera seu processo de preparo artesanal ou tecnificado, em comparação com outras redes de food service?

- Comparando com seus concorrentes diretos?

Acima da média ( ); Na média ( ); Abaixo da média ( )

- Comparando com outras redes (concorrentes indiretos)?

Acima da média ( ); Na média ( ); Abaixo da média ( )

\section{B) ATENDIMENTO (SERVIÇO)}

1) EXTENSÃO

○ Qual a extensão do atendimento?

- Full Service

- Tiket First (Paga antes e consome no local)

- No Service (Paga antes e não consome no local)

2) EXTRUTURA PARA CONSUMO

○ Qual o local destinado ao consumo (quantas unidades)?

- Salão Próprio (Loja Externa; Loja de Rua)

- Salão cativo em centro comercial (Praça ou corredor)

- Praça de alimentação (Box em Shopping)

- Balcão (em pé)

- Não tem (take away)

- Não tem (Delivery)

○ Existem garçons que atendem as mesas? Ou somente atendentes de balcão?

- Qual o número de atendentes (garçons ou balconistas) da loja?

- Quanto demora (tempo) a captação do pedido? Existe orientação do garçom, ele contribui, ajuda, orienta, empurra? 
Significativo ( ) Médio ( ) Baixo ( )

- Qual o tempo médio de consumo (permanêcia na loja)?

- Tempo de preparo

- Tempo de consumo

○ Outros Serviços (incidência)?

- Tem delivery (tem pedidos por telefone?)

- Tem Drive Thrue

- Tem Quiosque Satélite

- Tem um Cafè?

- Estacionamento (local próprio)

- Manobrista

- Vallet terceirizado

- Segurança privada

- Como varia o número médio de funcionários entre Loja Externa e Loja em Shopping?

- Como varia o número de cargos diferentes?

- A supervisão é a mesma?

- Número de funcionários?

- Turnos?

- Existe diferença na dificuldade de se administrar uma Loja de Externa e uma Loja de Shopping?

Significativa ( ) Média ( ) Baixa ( )

\section{PARTE IV - ESTRATÉGIA COMPETITIVA}

1 Quem são seus principais concorrentes no segmento?

2 Como seriam classificados os principais concorrentes do segmento em relação à estratégia montada? (Estratégias: Preço, diferenciação do Produto?)

Algum comentário sobre a estratégia de cada concorrente? No que cada um se destaca? 


\section{ANEXO III}

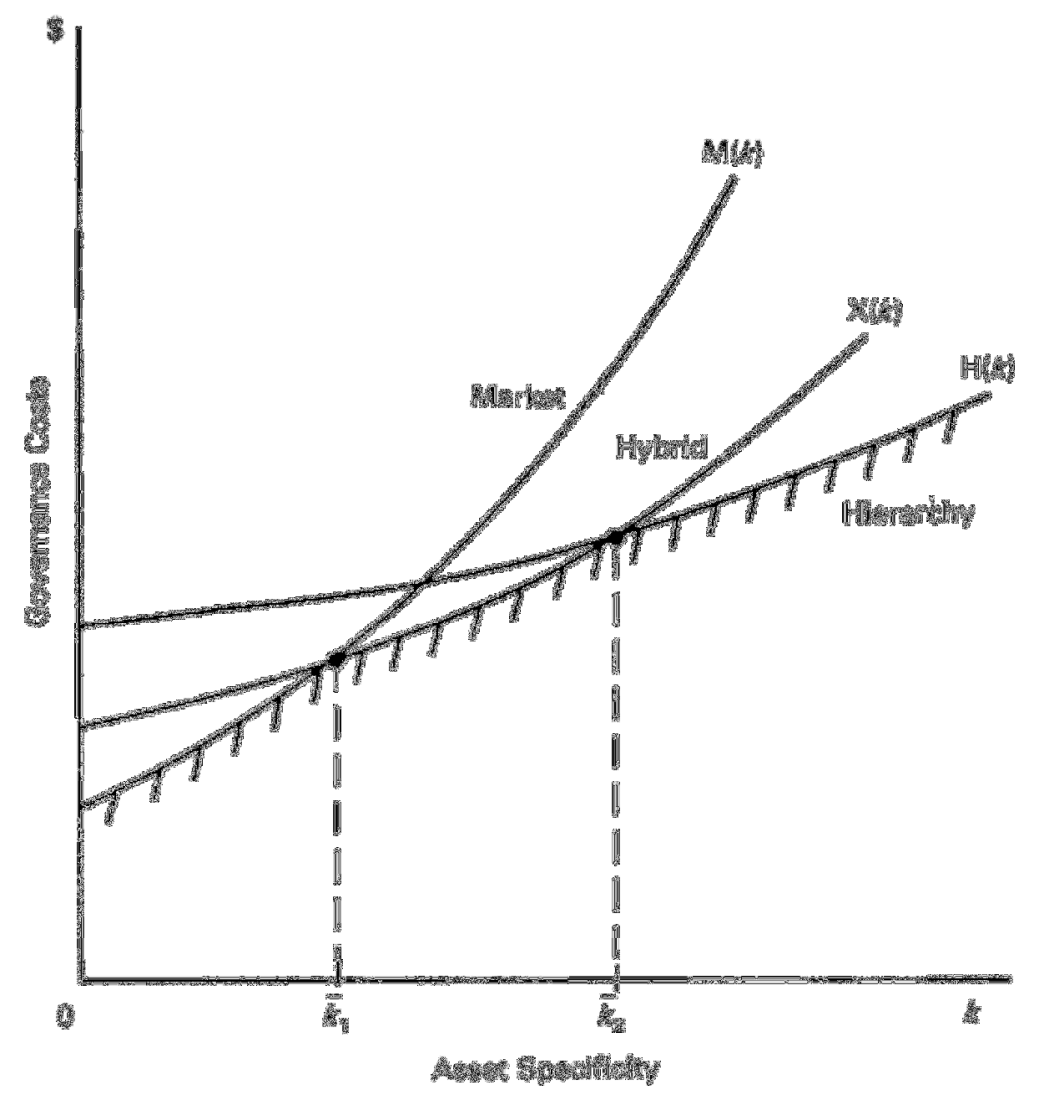

Figura A1 - Ativos Específicos e Custo de Governança Fonte: WILLIAMSON, 1991, p. 284

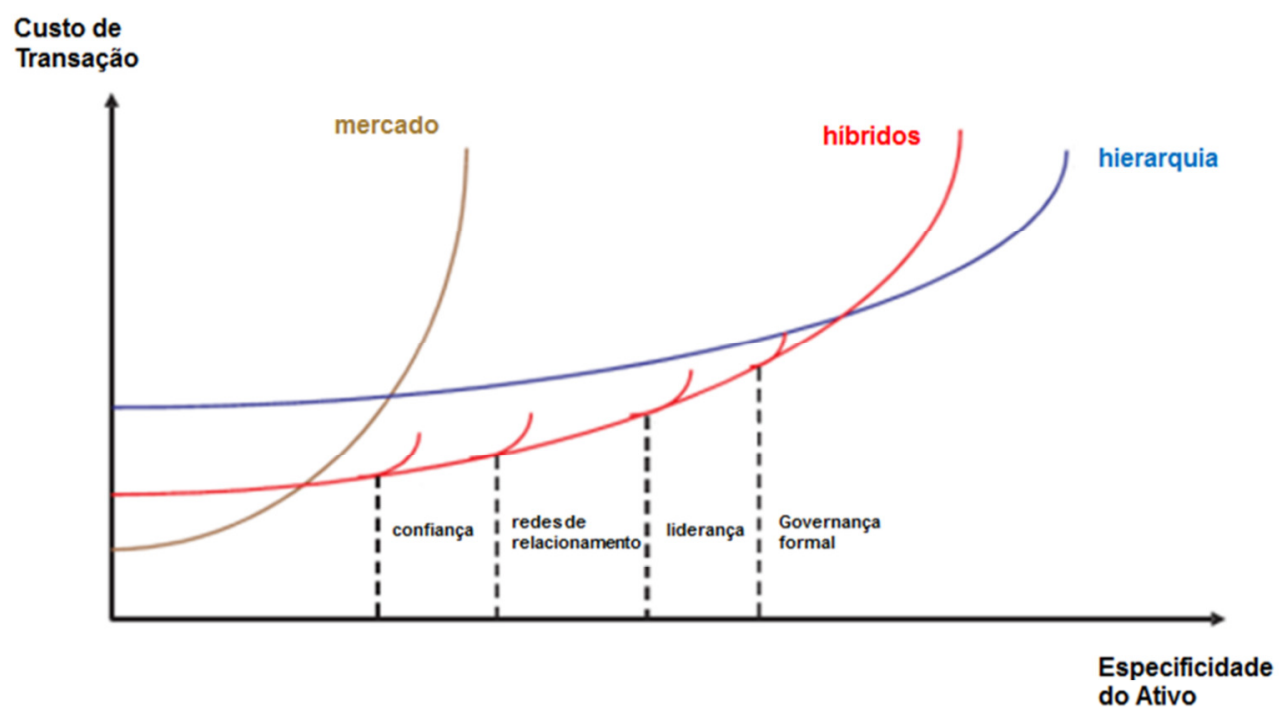

Figura A2: Uma tipologia para Formas Híbridas Fonte: Ménard (2004, p. 369, traduzido pelo autor 


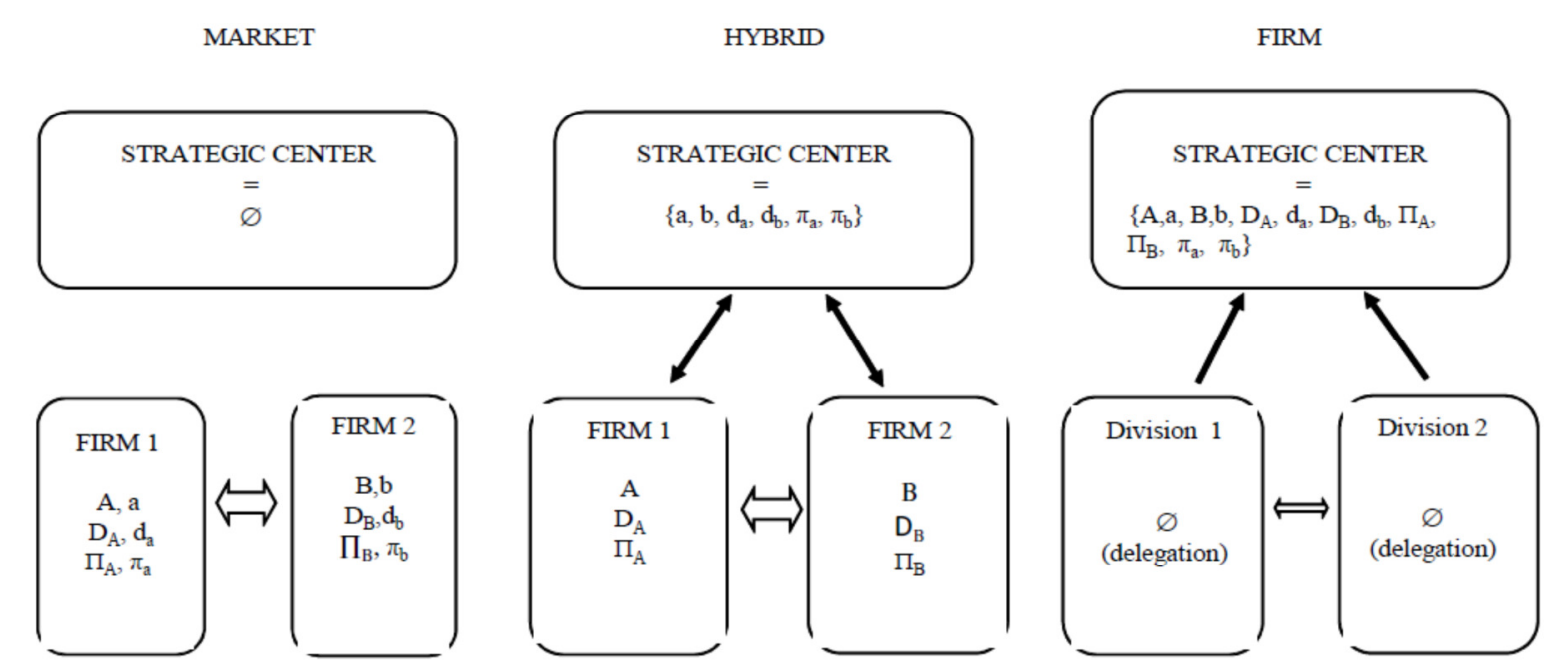

Figura A3: Contrastando Formas de Organização

Fonte: MÉNARD, 2010, p. 15

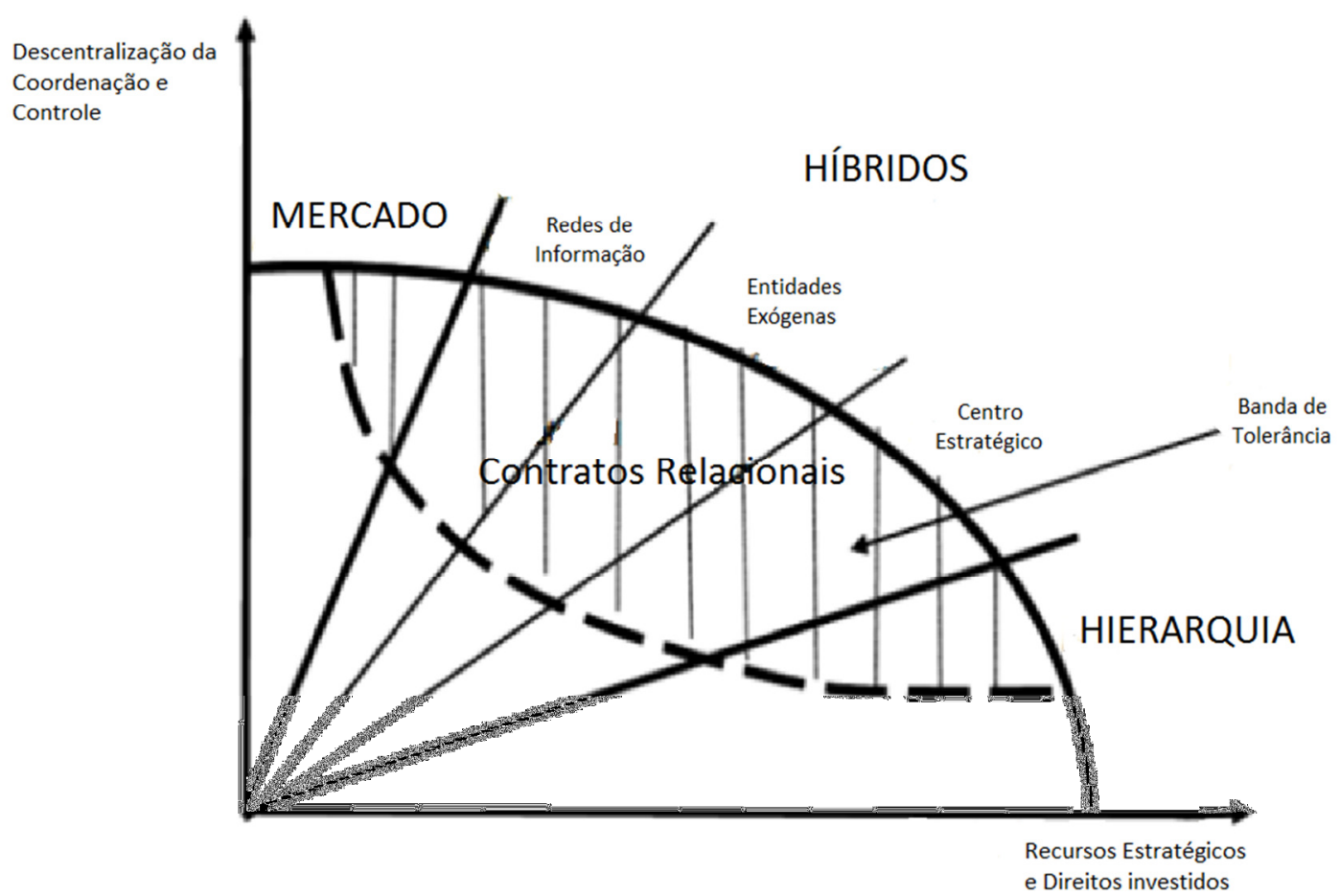

Figura A4: Tipologia de Formas Híbridas (2010)

Fonte: Ménard (2010, p. 50, traduzido para o português pelo autor 